UNIVERSIDADE DE SÃO PAULO

FACULDADE DE FILOSOFIA, LETRAS E CIÊNCIAS HUMANAS

DEPARTAMENTO DE FILOSOFIA

PROGRAMA DE PÓS-GRADUAÇÃO EM FILOSOFIA

CELSO MARQUES JUNIOR

O CAMINHO CARTESIANO: A CRÍTICA DE HEIDEGGER À FENOMENOLOGIA TRANSCENDENTAL DE HUSSERL

VERSÃO CORRIGIDA 
CELSO MARQUES JUNIOR

\title{
O CAMINHO CARTESIANO: A CRÍTICA DE HEIDEGGER À FENOMENOLOGIA TRANSCENDENTAL DE HUSSERL
}

\author{
VERSÃO CORRIGIDA
}

Dissertação apresentada ao Programa de Pósgraduação do Departamento de Filosofia da Faculdade de Filosofia, Letras e Ciências Humanas da Universidade de São Paulo, sob a orientação do Prof. Dr. Marcus Sacrini Ayres Ferraz, como requisito parcial para obtenção do título de Mestre em Filosofia.

São Paulo 
Autorizo a reprodução e divulgação total ou parcial des te trabalho, por qualquer meio convencionalou eletrônico, para fins de estudo e pesquisa, desde que citada a fonte.

Catalogação na Publicação

Serviço de Biblioteca e Documentação

Faculdade de Filosofia, Letras e Ciências Humanas da Universidade de São Paulo

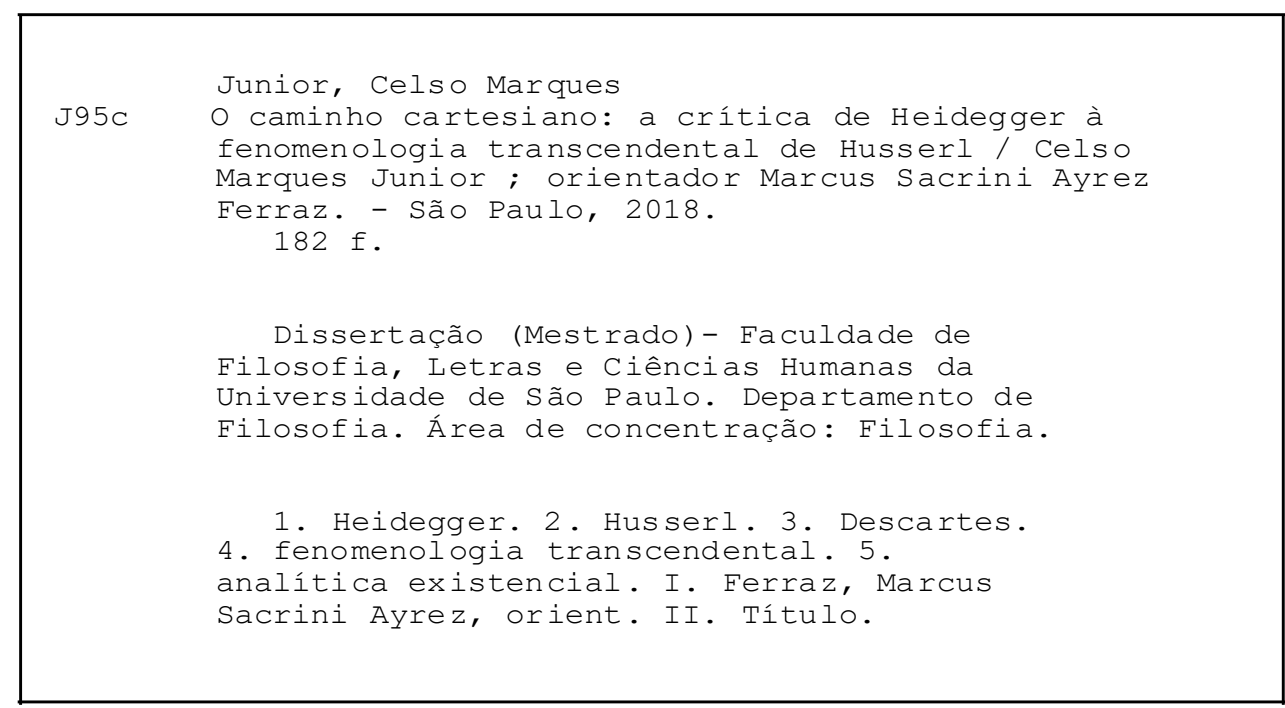




\title{
ENTREGA DO EXEMPLAR CORRIGIDO DA DISSERTAÇÃO/TESE Termo de Ciência e Concordância do (a) orientador (a)
}

\author{
Nome do (a) aluno (a): Celso Marques Junior \\ Data da defesa: 06/05/2019 \\ Nome do Prof. (a) orientador (a): Marcus Sacrini A. Ferraz
}

Nos termos da legislação vigente, declaro ESTAR CIENTE do conteúdo deste EXEMPLAR CORRIGIDO elaborado em atenção às sugestões dos membros da comissão Julgadora na sessão de defesa do trabalho, manifestando-me plenamente favorável ao seu encaminhamento e publicação no Portal Digital de Teses da USP.

São Paulo, 12/06/2019

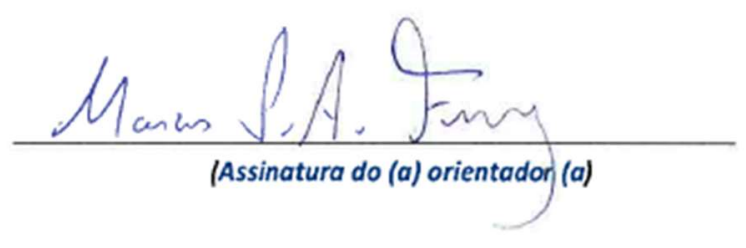




\section{Agradecimentos}

Ao professor Marcus Sacrini, cuja orientação rigorosíssima e a amizade constante possibilitaram-me percorrer veredas demasiadamente tortuosas. Por sua seriedade, mas também por sua serenidade, é ele tão merecedor das palavras de Erasmus quanto Morus: quanquam tu quidem, ut pro singulari quadam ingenii tui perspicacitate, longe lateque a vulgo dissentire soles, ita pro incredibili morum suavitate facilitateque cum omnibus omnium horarum hominem agere, et potes et gaudes.

Aos professores Eduardo Brandão, Alex de Campos Moura, Bento Prado Neto e José Luiz Bastos Neves pelas observações críticas e pelas sugestões fundamentais realizadas tanto no exame de qualificação quanto na defesa dessa dissertação.

Aos meus pais, Celso e Guiomar, pelo apoio e incentivo ao longo de todos esses anos seja na presença (em São Paulo) ou na ausência (em Roma).

Ao meu irmão, Daniel, pela companhia fiel e, sobretudo, pela paciência com meus estudos.

Aos amigos Gustavo Giacomini e Matheus Pustrelo, que sempre partilharam das inquietações e alegrias, ajudando este inepto a se situar de maneira menos vertiginosa no "mundoda-vida”. Seria injusto não mencionar que devo às nossas conversas boa parte do pouco que sei.

Aos amigos de aventuras romanas, Enrique Rojas ("Gordito"), Elmiro Gomes, Gerardo Franco ("Zapata”) e Rogério Matsumoto (“Chino").

Aos amigos Bruno Rosa, Rosi Marques, Paula Guisard e Marcus Baccega, pela partilha das inúmeras experiências, pelas longas conversas sobre filosofia medieval e principalmente por me resguardarem de momentos tenebrosos. Eles expressam o verdadeiro significado da caritas paulina.

Aos amigos, Andrés Eugui, Ícaro Luz, Armando Canado, Dalva Cardoso, Márcio Junior, Juliana Abril, Eider Cesario, Marcella Mancini, André Esquiante, Vivian Cavalcante, Jéssica Cristina, Rogério Galvão, André Sekkel, Nelson de Campos, Renan Perondi, Lucas Legnare, Daniel Guinsburg e Flávio Mello.

Aos funcionários da secretaria do Departamento de Filosofia.

O presente trabalho foi realizado com o apoio da Coordenação de Aperfeiçoamento de Pessoal de Nível Superior - Brasil (CAPES) - Código de Financiamento 001. 
"Basta un sólo discípulo para que el maestro prevarique".

Nicolás Gómez Dávila, Escolios a un texto implícito, I, p. 147 


\section{Resumo}

JUNIOR, C. M. O caminho cartesiano: a crítica de Heidegger à fenomenologia transcendental de Husserl. 2018. 182f. Dissertação (Mestrado). Faculdade de Filosofia, Letras e Ciências Humanas. Departamento de Filosofia. Universidade de São Paulo. 2018.

Este trabalho pretende investigar as relações existentes entre as filosofias de Edmund Husserl e Martin Heidegger a partir do traço cartesiano identificado na fenomenologia. Seu objetivo primeiro consiste em reconstruir a descrição husserliana da etapa transcendental de sua filosofia e analisar sua relação com o pensamento de Descartes. Em seguida, a investigação se voltará à exposição da crítica que Heidegger dirige ao projeto fenomenológico em suas preleções de Marburg e buscará compreender de que modo a crítica mesma, mais uma vez permeada pelas teses cartesianas, apresenta um caminho para a constituição da ontologia fundamental, cuja forma maturada terá seu lugar em Ser e Tempo.

Palavras-Chave: Husserl - Heidegger - Descartes - Fenomenologia Transcendental Analítica Existencial 


\begin{abstract}
JUNIOR, C. M. Treading the Cartesian path: Heidegger's criticism of Husserl's transcendental phenomenology. 2018. 182f. Dissertation (Master Degree). Faculdade de Filosofia, Letras e Ciências Humanas. Departamento de Filosofia. Universidade de São Paulo. 2018.
\end{abstract}

This dissertation investigates the existing relationship between Edmund Husserl's and Martin Heidegger's philosophies through the lenses of phenomenology and its Cartesian features. Revisiting Husserl's description of the transcendental stage of his philosophy and analyzing its connection with Descartes' thought is, thus, the main objective of this work. Thenceforth, we expose Heidegger's criticism over this phenomenological project, seen in his Marburg Lectures. His criticism is also suffused with the Cartesian theses, and therefore we attempt to understand how it may have laid the path to forging a fundamental ontology. An ontology whose mature configuration will then find its place in Being and Time.

Key-words: Husserl - Heidegger - Descartes - Transcendental Phenomenology Existential Analytic 


\section{Índice}

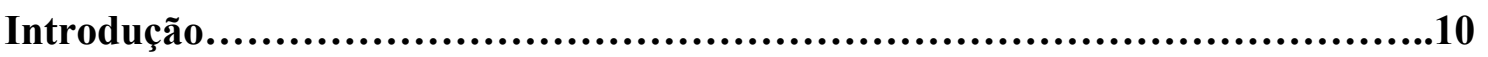

Capítulo 1 - Eversionis laus: a fenomenologia de Husserl e o cartesianismo.............18

$\mathrm{I}-\mathrm{A}$ eversio.............................................................. 18

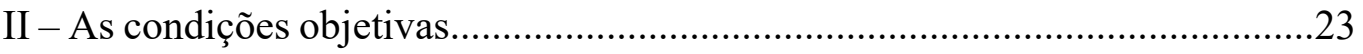

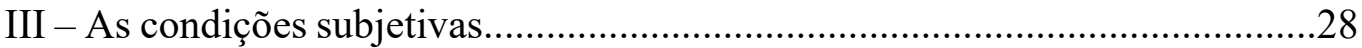

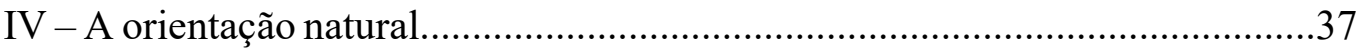

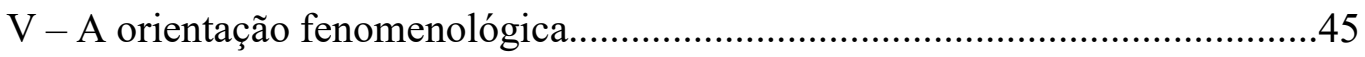

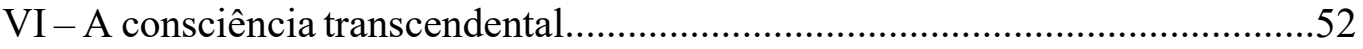

Capítulo 2 - Die erkannte Erkenntnis: a interpretação e a crítica de Heidegger à fenomenologia transcendental de Husserl.....................................................................64

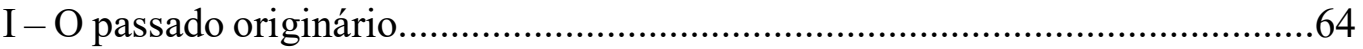

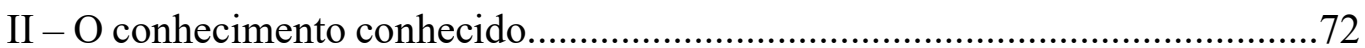

III - O Ser absoluto da consciência..................................................................97

Capítulo 3 - Das Dasein: a pergunta pelo Ser e a analítica existencial......................118

I - A concepção tradicional de Ser..................................................................118

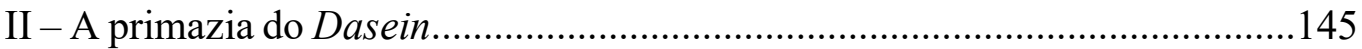

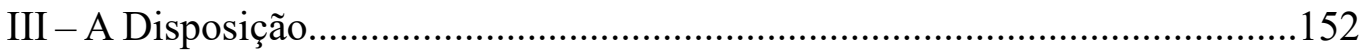

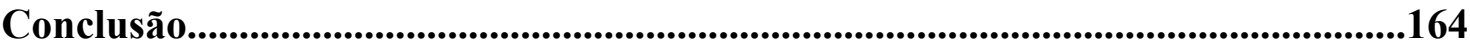

Referências bibliográficas............................................................................................................173 


\section{Introdução}

Em Cadernos de uma guerra estranha, relatando seu itinerário intelectual e descrevendo sua relação com o pensamento fenomenológico, Sartre comentava:

"Husserl havia me tomado, eu via tudo através das perspectivas de sua filosofia que me era, aliás, mais acessível por sua aparência de cartesianismo"1.

A impressão do jovem filósofo francês, acometido pela inebriante novidade de uma doutrina da consciência transcendental, não era inteiramente equivocada. Qualquer leitor minimamente atento jamais deixará de apontar a sensação recorrente de ouvir uma espécie de murmúrio que emana das páginas de Husserl e de identificá-lo, sempre que possível, com a voz de Descartes. Mas esse eco cartesiano seria apenas ilusório, restringindo-se a uma "aparência" que nos facilitaria o acesso ao árido domínio dos textos husserlianos? Na verdade, tal presença é mais do que um efêmero balbucio: muito além de ser uma simples figura de comparação, eleita graças a certas similitudes filosóficas, Descartes é, para Husserl, o inspirador insubstituível, a autoridade sob cujo patronato se coloca a própria fenomenologia. Não é por acaso - nem mesmo com o intuito de convencer intelectuais franceses pela via do $\pi \dot{\alpha} \theta$ o - que as meditações fenomenológicas carregam o nome Meditações Cartesianas: apesar das frequentes críticas que suas páginas trazem ao projeto cartesiano (para não dizer simplesmente que provocam a ruína de quase todo seu edifício), elas se conservam sempre atadas às Meditationes de prima philosophia de um modo muito particular. Sendo assim, se a inspiração se mostra tão vasta, a ponto de apadrinhar esse batismo e de revelar um laço inquebrantável, é preciso não só reconhecer abertamente essa origem como também é necessário perguntar: em que sentido a filosofia de Descartes se torna o fio por meio do qual irá se coser a trama da fenomenologia?

Uma passagem das preleções de 1923, reunidas sob o sugestivo título de Filosofia Primeira, parece oferecer um caminho para a resposta. Afinal, é ali que podemos observar o fenomenólogo se levantar em defesa do ceticismo. Expondo suas reflexões sobre as principais correntes filosóficas, Husserl dirá que a Skepsis, longe de ser simples letra

\footnotetext{
${ }^{1}$ Jean-Paul Sartre, Les carnets de la drôle de guerre, p. 225.
} 
morta no curso da história do pensamento, ainda perdura porque conserva em si uma significação "imortal". Mas o que assegura essa "imortalidade" de uma doutrina supostamente insustentável e que julgávamos já extinta? Ora, entender exatamente em que consiste seu caráter imorredouro exigirá um retorno ao seu berço. Pois, ao voltarmos nossa visada à orientação cética própria da sofística, notaremos no coração da postura dubitante a presença de uma "verdade" (Wahrheitsgehalt) que não mais se apresenta como uma dentre outras tantas, mas que abre um "novo reino de conhecimento a partir do qual todo conhecimento, ao termo e ao cabo, deveria identificar sua dignidade" 2 . Uma "verdade majestosa" que, aos olhos de Husserl, levava o sofista a vaticinar, desde muito cedo, que o objeto só é “objeto" enquanto experimentado pelo sujeito em seus modos de doação "subjetivos" e sempre variáveis. O que é, de fato, uma afirmação espantosa: não só por subverter a compreensão tradicional que se tem das lições de Protágoras e Górgias, mas por observar em seus ensinamentos um esboço da tendência ao tratamento da "totalidade da objetividade em geral" como objeto do conhecimento de uma consciência, quer dizer, por reconhecer na sofística a existência - ainda que mal-ajambrada - de um "impulso transcendental" que, aparentemente, filósofo algum soube dar a devida atenção ${ }^{3}$. Filósofo algum? Filósofo algum... até Descartes. Pois fora ele o primeiro assegura Husserl - a desmistificar o teor da argumentação cética e a lançar luz ao fato de que ela guarda em si a semente ainda não germinada de uma ciência objetiva e da fundamentação universal da filosofia. É somente com a redação das duas primeiras meditações que se colocará um ponto final ao ocultamento e se tornará manifesto o arcano do ceticismo: lá repousa a prova cabal de que a argumentação cética, mesmo em seu semblante hiperbólico, carrega consigo uma impossibilidade inerente; lá jaz a comprovação de que seu "movimento natural", ao invés de negar o encontro com a Verdade, desemboca na ideia necessária e originária do fundamento. Assim, sob a pena de Descartes, vê-se como o ceticismo está impedido - isto é, essencialmente impedido de consistir num fim em si mesmo e como seu prelúdio é sua própria derrocada. Forcemolo então ao seu limite e esse será o resultado: embora a dúvida pareça tudo consumir em sua negação absoluta, deixando-nos à mercê do gênio maligno, ela acaba por revelar, na contracorrente de sua íntima motivação, o indubitável vulto do cogito. Daí se poder dizer que "[Descartes] se apropriou teoricamente do solo ontológico universal, o qual até mesmo as negações céticas mais extremas devem pressupor (...) O ceticismo, e somente

\footnotetext{
${ }^{2}$ Edmund Husserl, Erste Philosophie, I, p. 58.

${ }^{3}$ Idem, Ibidem, p. 60.
} 
ele, tem a grande missão histórica de conduzir a filosofia, obrigatoriamente, pelo caminho da filosofia transcendental" ${ }^{\prime 4}$.

Isso equivaleria a entender que a boa filosofia deveria ter seu início garantido por uma radical exclusão de pressupostos caso desejasse se apropriar daquele seguro refúgio de certeza, a subjetividade transcendental? É exatamente o que enunciarão as linhas nas quais se desdobram as Meditationes: elas vão expor o veredicto de que é somente por obra da orientação dilapidante que se pode obter o firmíssimo solo para a construção da ciência rigorosa. E para alguém como Husserl, cuja postura sempre se alinhou à busca do máximo rigor no pensamento, essa fórmula (com sabor de panaceia) era tentadora demais para que dela se abrisse mão: tal como o cartesianismo, a fenomenologia vai nascer graças ao esforço parturiente da operação cética; tanto lá quanto cá, "a ciência última" vem ao mundo pelas mãos da "dissolução de todos os prejuízos". Tudo deve ser posto abaixo antes que se possa começar a estruturar a universalissima sapientia ou circunscrever a consciência pura - essa é a palavra de ordem. Donde, então, se começa a distinguir qual é a coordenada principal que orienta a relação - nem sempre amistosa, é verdade - entre as filosofias de Husserl e Descartes. Se é possível identificar a presença de uma aliança que as une, deve-se aprender a reconhecer que o material do qual ela é forjada não pode ser outro senão a eversio: é sempre em nome de uma inigualável purgação que ambas dão início às suas respectivas atividades reflexivas. É por isso que Husserl, ao adentrar os domínios filosóficos, o fará como outrora fizera Descartes. Mas é por isso também que cada passo dado nesse caminho se realizará contra ele. Ora, se todo começo consiste em provocar a ruína dos juízos previamente estabelecidos, é esperado do fenomenólogo - fiel à sua herança - que não hesite ou ceda ao remorso no momento decisivo do parricídio. $\mathrm{Na}$ verdade, para fazer justiça ao que lhe fora transmitido, ele deverá se regozijar com a demonstração de que a eversio de seu antecessor sofre de uma evidente insuficiência, e que muitas de suas "percepções claras e distintas" ainda estão turvadas por “obscurantismos fatídicos" (verhängnisvolle Unklarheiten). Em suma, o preceito inaugural exigirá do discípulo que abjure, mui orgulhosamente, a filosofia de seu mestre:

"Descartes não apreendeu uma filosofia que se funda de maneira nova e radical; ou o que é essencialmente a mesma coisa, não apreendeu o sentido autêntico de uma fundamentação da ciência e do conhecimento transcendentais, enraizados no ego cogito.

\footnotetext{
${ }^{4}$ Idem, Ibidem, p. 61-62.
} 
Isto tem novamente sua razão de ser no fato de que ele não se colocou, na doutrina, de modo correto junto ao ceticismo". 5

É claro - diz Husserl - que Descartes merece os louros por ter elucidado a verdade encoberta no ceticismo e por ter aberto pela primeira vez a via para uma filosofia transcendental. Todavia, tal honraria parecia ser insuficiente para lhe garantir a redenção de um "pecado" tão grave: mesmo defronte da porta de acesso ao domínio da subjetividade pura, a pressa característica de seu estilo cortante e seu apreço pelo hábito dos geômetras o impediram de se apoderar do mais profundo sentido de sua descoberta. A miopia gerada por seus pressupostos o proibiu de ver com clareza que a sentença "cogito, ergo sum" não se resumia à trivialidade de um ponto, mas se tratava de uma esfera de ser inteiramente nova. Descartes, de fato, não sabia onde estava. Daí o tom de quase vitupério que Husserl empregava ao acusá-lo de partilhar do impreciso senso de direção de Colombo: "Descartes portou-se como Colombo, que descobriu um novo continente, mas que nada sabia a respeito disso e acreditou ter descoberto somente um

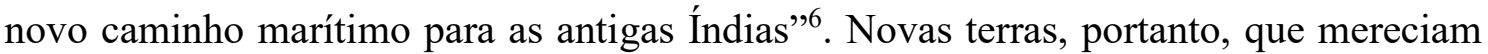
ser exploradas. E é aí que principia a tarefa da fenomenologia; é assim que tem início e se desdobra - pedindo perdão, de antemão, pela expressão paradoxal, mas verdadeira seu cartesianismo anti-cartesiano.

Em sua maioria, os intérpretes hodiernos da filosofia de Husserl parecem não se ocupar detidamente da gênese do pensamento fenomenológico em sua união com a filosofia das Meditationes. E por que isso ocorre? Talvez por julgarem, no melhor dos casos (mas ainda sem boa razão), que suas questões possam ser perfeitamente compreendidas mesmo na ausência consciente da consideração do manancial de onde elas jorram. Ou talvez porque já tenham digerido tão bem a tópica (algo de que certamente duvidamos), a ponto de entrelaçá-la secretamente em seu discurso, condicionando-a a cada etapa de sua investigação. Ou ainda por acreditarem, numa espécie de comportamento comprometedor a todo aquele que se autointitula "fenomenólogo", que uma perspectiva pouquíssimo considerada passe por muito bem conhecida - reavivando deste modo a dificuldade da Selbstverständlichkeit ou caindo novamente no "sono dogmático"... Seja qual for sua motivação, a verdade é que nem sempre vagamos em meio a tal silêncio constrangedor. Fato é que demorou pouco (provavelmente menos tempo do

\footnotetext{
${ }^{5}$ Idem, Ibidem, p. 64.

${ }^{6}$ Idem, Ibidem, p. 63-64.
} 
que transcorreu até seu abandono) para que este problema viesse a ocupar o centro do proscênio. Bastou, por assim dizer, uma geração de fenomenólogos. Em suas preleções ministradas em Marburg na década de 1920, Heidegger já farejava a questão e empenhava-se em clarificar seus termos: ali era possível vislumbrar como se operava a hábil articulação das obras de Descartes e Husserl e, mais do que isto, como o estudo minucioso desta ligação servia aos propósitos estruturais de sua própria filosofia sob a forma de uma crítica. Quer dizer então que os intérpretes heideggerianos, ao buscarem esclarecer a relação existente entre o transcendental e o hermenêutico, foram mais felizes e puderam se deparar com aquele traço fundamental, tanto para a fenomenologia quanto para a analítica existencial em construção? Não exatamente, uma vez que as primeiras leituras ainda padeciam da escassez de referências: aqueles que se dispunham à tal empreitada podiam contar apenas com as minguadas remissões presentes na epístola de 1927 (na qual se debatia sobre o artigo escrito para a Enciclopédia Britânica), no texto Meu caminho na fenomenologia (originalmente publicado em 1963), no diálogo travado com Jean Beaufret em Seminário em Zähringen e nos escritos de juventude (A doutrina do juízo no psicologismo e A doutrina das categorias e da significação de Duns Scotus) - além, é claro, das concisas menções de Ser e Tempo ${ }^{7}$. Mas a publicação da Gesamtausgabe (Obras Completas), sobretudo da seção referente às preleções marburguesas, não alteraria - poderíamos perguntar - definitivamente esse cenário, preenchendo os incômodos hiatos no diálogo entre os filósofos? Em parte responderíamos. Afinal, se é certo que os estudos fulcrais (e pioneiros) de Jean-Luc Marion $^{8}$ ofertavam a preciosa indicação de um caminho de análise, na medida em que nos convidavam às comparações conceituais entre as obras de Descartes, Husserl e Heidegger, não é menos certo que essa frutífera perspectiva iria, vez ou outra, se perder sob a pena de seus epígonos ${ }^{9}$. Voltando seu interesse ora ao eixo da relação que envolvia

\footnotetext{
${ }^{7}$ Podemos citar como exemplos desses estudos: a tese de doutoramento do cardeal Karl Lehmann (Von Ursprung und Sinn der Seinsfrage im Denken Martin Heideggers. Versuch einer Ortsbestimmung), a tese de doutoramento de Ernildo Stein (Compreensão e Finitude: estrutura e movimento da interrogação heideggeriana) e o escrito de Eugen Fink (Zur ontologischen Frühgeschichte von Raum - Zeit Bewegung).

${ }^{8}$ Cf. Jean-Luc Marion, Reduction and Givenness. Cf. também a interpretação onto-teo-lógica que Marion realiza da filosofia cartesiana em: Idem, Sur le prisme métaphysique de Descartes. Constitution et limites de l'onto-théo-logie dans la pensée cartésienne.

${ }^{9}$ Apesar das pontuais dificuldades, é preciso destacar a grande contribuição desses estudos para a compreensão da filosofia heideggeriana. Se eventualmente contestamos alguns deles no curso de nossa investigação, é sempre com grande deferência. Como dizia Gérard Lébrun, não o fazemos por obra de um espírito pueril ou por vontade de gerar ingratas polêmicas, mas sim para lançar alguma luz sobre certos aspectos que seus esforços reflexivos deixaram na sombra. Cf. Søren Overgaard, Husserl and Heidegger on being in the world; Friedrich-Wilhelm v. Herrmann, Hermeneutik und Reflexion; Jean-François
} 
as filosofias de Descartes e Heidegger, ora de Husserl e Heidegger, tais comentadores comprometiam suas teses ao pecar pela falta: ou acabavam por excluir um dos elementos necessários à reconstrução do sentido da ontologia fundamental, ou retraçavam-no em linhas demasiadamente gerais, simplificando suas doutrinas; noutras palavras, não compreendiam que esse "quadro filosófico" assumia a forma de um tríptico, cujas partes carecem de estar intimamente ligadas para que possam revelar seu pleno significado.

Mas diante dum cenário que aparenta ser pouco consolador, o que há de se fazer? Resta somente indagar mais uma vez: como a crítica do remanescente cartesianismo da fenomenologia conduz à autêntica pergunta pelo Ser? Se tudo é caminho (Alles ist Weg, dizia Heidegger), que nova via é essa que se abre à nossa frente (em lugar do "caminho tipicamente cartesiano" do pensamento de Husserl) e que nos permite cumprir agora o destino da metafísica? Ora, esboçar uma resposta detalhada à tal questão, resgatando e entrecruzando suas partes essenciais, é a proposta desse escrito. No entanto, que o leitor prestes a adentrá-lo não espere encontrar em suas páginas algo tão em voga em tempos de desvario e glosa indolente: elas não expressam - salvo melhor juízo - nenhuma tentativa artificiosa de fazer as obras analisadas cederem ou se curvarem aos critérios arbitrários de nossa vontade; aos que têm gosto por deturpações e mutilações textuais, acreditando piamente que esta prática insidiosa e "violenta" seja um sinônimo do próprio "filosofar", estejam avisados de que não colherão daqui afirmações como aquela de von Herrmann: "sob o ângulo da fenomenologia do Dasein, e se não consideramos senão as linhas gerais do curso do pensamento cartesiano, sem ter em conta suas decisões ontológicas concretas..."10. Não se quer aqui, sabe-se lá em nome de qual ideologia, apagar as "inconveniências" de um texto para em seguida carregar nas tintas daquilo que possa apresentar alguma serventia na sustentação de hipóteses infecundas. Isso significaria não apenas trair a profundidade das palavras de cada um dos filósofos que surgem em nosso campo de consideração, mas seria também aviltar a lida do historiador da filosofia como um todo. É a fim de evitar extravios dessa ordem - infelizmente ainda bastante comuns - que nossa pretensão nesse trabalho se aproxima de uma verdadeira

Courtine, Les méditations cartésiennes de Martin Heidegger; Virginie Palette, Heideggers früher Durchbruch zur hermeneutischen Phänomenologie als Kritik des 'cartesianischen Weges' in Husserls Ideen I; Denis Fisette, Les cours de Marbourg et la phénoménologie; Christophe Perrin, Entendre la métaphysique. Les significations de la pensée de Descartes dans l'oeuvres de Heidegger; Marco Antonio Valentim, Heidegger sobre a fenomenologia husserliana:a filosofia transcendental como ontologia; Alberto Marcos Onate, O lugar do transcendental.

${ }^{10}$ Friedrich-Wilhelm v. Herrmann, Husserl et Descartes, p. 20. 
confissão de modéstia: buscando evitar os volteios e os deslocamentos improdutivos, que não raro resultam em anacronismos excruciantes e conclusões fantasiosas, deseja-se tão somente retraçar a gênese de determinados conceitos filosóficos (iluminando as nuances que, nesse caso particular, exigem sua criação, sua reformulação e sua crítica) e remetêlos, a partir daí, às funções que cumprem no interior da trama daquela forma de pensamento à qual pertencem ${ }^{11}$. Mais especificamente e sob a égide da boa heurística, nossa intenção reside em compreender de que maneira o conceito cartesiano de eversio atua como uma bússola capaz de nos orientar no horizonte do diálogo travado entre Husserl e Heidegger. Nesse sentido, o primeiro capítulo investigará a imbricação existente entre as filosofias de Descartes e Husserl. Partindo, por um lado, da aguda indicação de uma metáfora kierkegaardiana sobre a natureza da dúvida enquanto princípio da filosofia e, por outro, do relato husserliano que confirma sua veracidade, procuraremos evidenciar de que maneira a fenomenologia só pode se distanciar do cartesianismo na medida em que ambos permanecem acorrentados um ao outro pela prescrição da "exclusão de pressupostos" - e como esta corrente se torna tanto mais sólida quanto mais se radicaliza o ímpeto purificador. Na sequência, o segundo capítulo adotará a tarefa de mostrar como Heidegger já identificava os termos pelos quais se estabelecia o vínculo entre os pensadores que optavam por dar início às suas ocupações por meio do ato de evertere. Recorrendo às preleções ministradas em Marburg, sobretudo Introdução à pesquisa fenomenológica e Prolegômenos para a história do conceito de tempo, acompanharemos como as noções de passado originário e preocupação com o conhecimento conhecido eram empregadas na compreensão daquele "acordo tácito" que insistia em conservar-se intacto, apesar de toda tentativa de ruptura. Nesse ponto será possível observar a razão pela qual o pretenso "Ser absoluto da consciência transcendental" era acusado de atraiçoar o postulado de "retorno às coisas mesmas", fazendo da fenomenologia uma disciplina essencialmente "não-fenomenológica". Por fim, o terceiro capítulo examinará de que maneira Heidegger alia Husserl a uma história da filosofia profundamente marcada pela falta de uma autêntica pergunta pelo Ser.

\footnotetext{
11 "Quando se procura circunscrever a originalidade adquirida por um conceito que o autor recebe da tradição, é sempre preciso investigar o momento em que esse conceito foi determinado de maneira distinta, recebeu uma feição até então insuspeitada. É quando se descobrem cumplicidades inesperadas entre doutrinas superficialmente rivais. Na verdade, é apenas restituindo uma filosofia à rede conceitual a que está ligada que se compreende melhor a influência que ela ainda exerce sobre nós". Cf. Gérard Lebrun, $A$ filosofia e sua história, p.13. Ou no aforismo de Gómez Dávila: "Buen historiador de la filosofia no es el que expone correctamente el contenido de las doctrinas, es el que vuelve inteligible la posibilidad de pensarlas”. Cf. Nicolás Gómez Dávila, Escolios a un texto implícito, p. 1320.
} 
Apontaremos ali de que modo o preceito metódico das Meditationes não apenas infundia a clássica confusão metafísica (tomar o ente pelo Ser) no coração da fenomenologia, mas também obstava, desde o princípio, a única via de acesso à ontologia fundamental - o Dasein. A partir daí buscaremos descrever os contornos que conferem primazia a este ente, bem como os pilares de sua estrutura originária - o que, por sua vez, nos permitirá demonstrar o caráter basilar do conceito de disposição para a analítica existencial e a impossibilidade de se continuar a sustentar a tese corrente de uma " $€$ ' $\chi \chi \chi$ ' heideggeriana". 


\title{
Capítulo 1
}

\section{Eversionis laus: a fenomenologia de Husserl e o cartesianismo}

\begin{abstract}
"Perante idéias correntemente aceitas, teses que pareciam evidentes, afirmações que tinham passado até então por científicas, ela sussurra ao ouvido do filósofo a palavra: impossível (...) Força singular este poder intuitivo da negação! Como é que ela não chamou a mais tempo a atenção dos historiadores da filosofia?" Henri Bergson, La pensée et le mouvant.
\end{abstract}

"E os próprios olhos, de cada um de nós, padecem viciação de origem, defeitos com que cresceram e a que se afizeram, mais e mais (...) Não vê porque mal advertido, avezado; diria eu, ainda adormecido, sem desenvolver sequer as mais necessárias novas percepções." João Guimarães Rosa, $O$ espelho, Primeiras Estórias.

\section{I - A eversio}

A epistemologia de Husserl permanece fundamentalmente cartesiana ou seus esforços reflexivos foram capazes de lhe conceder a tão almejada independência das Meditationes? Eis aí uma questão que é, à primeira vista, embaraçosa. Impulsionada pelas remissões que Sartre e Heidegger fizeram a Descartes em suas considerações sobre a filosofia husserliana, a pergunta parece ter gerado uma querela freqüente entre aqueles que passaram a se ocupar da fenomenologia: não se carece de uma investigação assídua para que sejam encontrados tanto os defensores da pureza fenomenológica quanto algozes que insistem em agrilhoá-la às teses cartesianas. Independente do caminho a ser trilhado, fato é que este embrolho tomou um aspecto irresoluto, e a busca pela vitória neste prélio parece ter feito seus partícipes cegos à letra dos textos de Husserl e Descartes. Em lugar de sérias explicitações, o que se obteve foi apenas uma perpetuação de vagueza. Assim sendo, a questão permanece aberta, à espera de uma determinação de seu sentido, o qual é também, em última instância, a determinação do sentido da própria fenomenologia. Mas se a indagação sobre a relação entre fenomenologia e cartesianismo é fundamental e exige que o fenomenólogo a tome como parte de sua tarefa, onde poderíamos dela encontrar algum indício que desvelasse seu tracejado sinuoso? 
As Meditações Cartesianas sem dúvida constituem a mais clara exposição da lógica que regula o encontro da fenomenologia com o cartesianismo em sua medida meticulosa. É bem sabido que a primeira das meditações de Husserl toma a forma de um decoroso panegírico e de uma confissão que os estudos das Meditationes de prima philosophia atuaram de maneira direta na elaboração do horizonte transcendental de sua filosofia. A inspiração exercida fora tão larga que levou Husserl a definir a fenomenologia da seguinte maneira:

"Por isto, poder-se-ía quase denominá-la [a fenomenologia] um neocartesianismo, caso o desdobramento radical de certos motivos cartesianos não a tivesse levado a abandonar quase todo conteúdo doutrinal da filosofia cartesiana". ${ }^{2}$

Ora, estas palavras não devem ser ingenuamente consideradas. Muito além de um estratagema retórico empregado para mover as paixões de uma audiência francesa, são elas as mantenedoras da resposta à questão da relação. Ao apontar que a fenomenologia quase poderia ser denominada um neo-cartesianismo caso não fosse levada a abandonar quase todo conteúdo doutrinário que lhe era próprio, Husserl deixava transparecer nesta estrutura do "duplo-quase" a presença de um preceito que não apenas se manteve, mas atuou como motivo cartesiano contra o cartesianismo na concepção da fenomenologia. Quer dizer, a filosofia de Descartes trazia para o centro da cena uma orientação que filosofia alguma com pretensão de rigor poderia se furtar a reconhecer, orientação cuja marca de eternidade (Ewigkeitsbedeutung) obviamente ultrapassava as Meditationes e surgia em sua máxima força e clareza na doutrina husserliana. Conservava-se ali, no quase que escapava à recusa, o elemento cartesiano originário a permitir a concepção de uma filosofia autêntica.

Deve-se compreender então a reminiscência fundamental que permitiu à fenomenologia enraizar-se num solo muito mais firme do que aquele onde a filosofia moderna estava fixada. Em que ela consistia, afinal? O certo grau de hermetismo presente nas palavras de Husserl pode ser dissolvido tão logo se leia com atenção as linhas inicias das Meditationes, nas quais Descartes expõe as orientações exigidas àqueles que pretendem filosofar:

\footnotetext{
${ }^{12}$ Edmund Husserl, Cartesianische Meditationen, $§ 1$, p.43.
} 
"Portanto, que uma vez na vida fossem postas abaixo todas as coisas, recomeçando dos primeiros fundamentos, caso desejasse estabelecer algo firme e permanente nas ciências". ${ }^{13}$

Desta sentença atribuída à primeira das meditações matafísicas resta claro o procedimento a ser cumprido para que uma filosofia autêntica possa ter início: num momento único da vida, no qual o homem se converte em filósofo, ele somente se alça a tal posição por ser capaz de submeter a totalidade ao ato de evertere, ou seja, torna-se filósofo, na expectativa da construção de um saber atemporal em sua firmeza, ao cumprir a eversio. Será este conceito que Husserl tomará como orientação originária da filosofia cartesiana. Em seu significado mais profundo, a eversio é um ex-vertere, um fazer verter fora, uma retirada das coisas de seu sentido habitualmente concedido, uma extração da mansuetude que certa ignávia do pensar permitiu indevidamente conservar ${ }^{14}$; a eversio, portanto, não consiste numa volta ao particularismo das diferenças, mas visa os fundamentos - a fim de revirálos desde abaixo, na intenção de colapsar o todo que sobre eles se edifica: "mas porque, se os fundamentos afundam, desaba por si mesmo tudo que foi sobre eles edificado" (sed quia, suffossis fundamentis, quidquid iis superaedificatum est sponte collabitur $)^{15}$. Concebida deste modo, ela se converte na figura do expediente que abre caminho à fundamentação absolutamente racional, livre de todos os pressupostos nocivos que, porventura, venham a impedir itinerário da cientificidade rigorosa. Mais diretamente, traduzido para a linguagem husserliana, ela é um início de ruptura que permite estabelecer "evidências, das quais não se pode recuar". ${ }^{16}$ Reclamar a eversio faz com que o filósofo se comprometa intimamente com a demanda de um saber primevo.

Mas por qual razão Husserl se vê forçado a exumar o preceito cartesiano? Pelo mesmo exato motivo que Descartes o inscrevera na história da filosofia: reconhecidas

\footnotetext{
13 "Proinde funditus omnia semel in vita essa evertenda, atque a primis fundamentis denuo inchoandum, si quid aliquando firmum et mansurum cupiam in scientia stabilire”. René Descartes, Meditationes, Med. I, $\S 1$, p. 20.

${ }^{14}$ A fórmula cartesiana emula a passagem das Academica de Cícero: “(...) vel potius etiam totam vitam evertere funditus (...)”. Cícero, Academica Priorum, Liber II, X, §31. O sentido da eversio enquanto assolação ou de trazer o fundo à tona pode ser melhor observado na profusão da palavra poética de Virgílio, Eneida, I, 43:

Ipsa Iovis rapidum iaculata e nubibus ignem

Disiecitque rates evertitque aequora ventis.

(Das nuvens, de Júpiter lançou o ardente fogo

As naus frangeu e os mares com ventos solevou).

${ }^{15}$ René Descartes, Meditationes, Med. I, § 2, p. 22.

${ }^{16}$ Edmund Husserl, Cartesianische Meditationen, §1, p.43-44.
} 
como membra disiecta, as ciências são carentes de um fundamento. Não obstante seu desenvolvimento visível e o estado de completude que este desenvolvimento permitiu atingir, as ciências ainda residem numa imperfeição devido à ausência de clareza no que diz respeito aos seus pressupostos. No espírito científico, dirá Husserl, sopitou a noção de vivacidade e univocidade da filosofia, restando-lhe apenas a produção de uma literatura inautêntica e desconexa, cuja característica mais marcante é ser uma mera crítica aparente (Schein-Kritisieren), sem qualquer traço de responsabilidade para com a investigação cientificamente rigorosa. Mediante um cenário tão desolador, a conclusão de Husserl não poderia ser em nada diversa daquela que, de fato, expusera: quando as ciências se olvidam de seu preceito fundador e traem sua própria tarefa, o presente que se esboça quanto à situação do conhecimento só pode ser funesto. A única maneira de resgatar o conhecimento de sua condição subjugada e de rememorar as ciências do papel que deveriam cumprir na ordem do saber repousava na recuperação da crença moderna em uma humanidade completamente racional, resguardada por uma filosofia científica e autônoma. O ideal de uma ciência absoluta será então evocado na intenção de recuperar o verdadeiro filosofar. Com efeito, em face de tais mazelas, Husserl irá se indagar se já não é tempo oportuno de renovar a radical orientação cartesiana, a fim de permitir não somente um começo para o filósofo, mas ofertar também um princípio originário para a filosofia. Quer dizer, num momento de necessidade premente da busca pelo fundamento, o que melhor há de se fazer não é tudo "submeter à eversão (Umsturz) cartesiana e dar início a novas Meditationes de prima philosophia?" 17 A filosofia que assim principia, bem se sabe, não flutua no vazio ou se restringe à nulidade absoluta, mas aponta para um sentido específico: a partir da eversio, espera-se instaurar um conhecimento essencial, erigido na recusa dos pressupostos e com bases formadoras surgidas de si mesmo, numa auto-evidência de seus elementos. Uma filosofia absolutamente responsável por si mesma, confessa Husserl, é o caminho "através do qual se conduziu à fenomenologia transcendental" 18 .

Todavia, assumir a eversio cartesiana não é um procedimento simples, pois implica em conseqüência séria àquele que reivindica a herança. Qual seja ela, pode nos dizer, muito antes do relato de Husserl, um testemunho grafado em bom dinamarquês. Ao

\footnotetext{
${ }^{17}$ Edmund Husserl, Cartesianische Meditationen, §2, p.46-47.

18 “Jedenfalls bezeichnet sich damit der Weg, der zur transzendentalen Phänomenologie geführt hat". Idem, ibidem, p.47.
} 
relatar as intempéries do exercício filosófico de Johannes Climacus, Kierkegaard descrevia metaforicamente o movimento natural da conseqüência:

"Climacus lera, num velho livro de contos, a história de um cavaleiro que recebera de um trold uma espada fora do comum, a qual, dentre suas propriedades, tinha a de exigir sangue tão logo fosse tirada da bainha. Assim que o trold a entregou, o cavaleiro experimentou um desejo tão grande em vê-la, que a desembainhou imediatamente, e, vejam só, o trold teve de morder a grama pela raiz". ${ }^{19}$

Eis aí a conseqüência desprendida da eversio herdada: quando transmitida de um ao outro, tornava-se ela, nas mãos do agraciado, uma espada que havia de tomar a vida de seu benfeitor, por mais doloroso que fosse recompensá-lo desta forma. Assim, o filósofo que abraça a noção não pode ser grato a quem lha fornecera senão por meio de "uma sangrenta ingratidão", quer dizer, conservar o preceito da eversio exige daquele que dela faz uso uma espécie de fidelidade infiel. Não é por mero acaso que Husserl assume uma postura cartesiana (da recuperação do fundamento, alheio aos pré-juízos) contra o próprio Descartes; é uma necessidade de essência que a ceifa gnosiológica do discípulo jamais poupe o mestre. Neste sentido, se as Meditações Cartesianas redescobrem e despertam as Meditationes de prima philosophia, não é com o intuito de assumir invariavelmente cada uma de suas teses, mas sim com a intenção de recuperar a orientação permissiva de obter o fundamento último e, sobretudo, evitar seus "deslizes tentadores" (verführerische Verirrungen). Descartes propunha cumprir a eversio em seu mais alto grau, mas faltavalhe o rigor necessário para levar a tarefa a cabo; estará ao encargo da fenomenologia carregar o "fardo de fariseu" 20 que as Meditationes legaram à história da filosofia.

Mas o que havia na filosofia de Descartes que a tornava alvo do "cruento" juízo husserliano? O que operava em seu interior a ponto de impedir a construção de uma filosofia absoluta e digna de receber o epíteto de indubitável? Com razão Husserl afirmará que, se algo se conserva e já opera no pensamento cartesiano, é porque a eversio ali empregada claudica desde o princípio. Caso ela atuasse da maneira devida, as amplas noções de lógica e de teoria das ciências deveriam também ter sofrido seus efeitos, assim como as demais ciências. Ora, isto de fato não ocorria, já que Descartes insistia em

\footnotetext{
${ }^{19}$ Søren Kierkegaard, Johannes Climacus ou De omnibus dubitandum est, cap. II, §2b, p. 84-85.

20 “Assim, pois, os filósofos são piores que os fariseus, sobre os quais lemos que impõem pesados fardos, sem eles mesmos erguerem um dedo para levantá-los. Pouco importa que não os levantem, desde que possam ler levantados". Idem, Ibidem, (Pap. IV B 17), p. 124.
} 
conservar a geometria como um ideal científico: era através do privilégio concedido ao ordo geometricus que se determinava a apreensão da certeza irredutível do ego axiomático e dele se faziam deduzir os princípios subseqüentes, no progressivo desdobramento que marcava a passagem de uma meditação à outra. Por isso, a aceitação de uma geometria intacta em face do procedimento inicial da filosofia e a doação de sua forma à sapiência universal eram os pré-juízos fatídicos que impediam Descartes de cumprir sua tarefa. A situação de Husserl diante do cartesianismo era tal que se tornava impossível acatar suas determinações primeiras de validade (de uma geometria como ciência ideal) e exigia uma nova estruturação da teoria do conhecimento. Que a fenomenologia assim agisse, num ato de recavar os fundamentos, era a mais pura significação de que não se dava as costas às Meditationes por mera contumácia ou por um insólito desejo fundacionista; na verdade, elas se viam recusadas por conta de um máximo respeito ao seu início enquanto filosofia e enquanto filosofar. O modo pelo qual o pensamento cartesiano se estruturou era condenável, mas seu preceito inaugural e "seu objetivo geral de absoluta fundamentação da ciência" deveriam permanecer conservados. $^{21}$

\section{II - As condições objetivas}

O intérprete de Husserl não deve crer piamente que a esta ambigüidade, marca de uma afinidade eletiva, esteja restrita à sua descrição sistemática das Meditações Cartesianas ou mesmo, numa concessão pouco mais ampla, à fenomenologia transcendental que surge pela primeira vez em sua forma maturada em Idéias I. Mas se ela não se circunscreve somente a tais momentos, cabe perguntar: quando este trato singular com Descartes (de ser cartesiano sem sê-lo propriamente) fará sua aparição no cenário fenomenológico? Sob a vigia da eversio, a origem da relação entre as filosofias de Husserl e Descartes se confunde com a origem da própria fenomenologia, quer dizer, quando a fenomenologia vinha à luz, ela apenas se legitimava e reconhecia sua autenticidade naquele nó górdio da complexa relação que a atrelava ao cartesianismo. Isto significa que já nos Prolegômenos à Lógica Pura - atestada certidão de nascimento da fenomenologia - era visível como todo esforço despendido por Husserl se voltava ao

\footnotetext{
${ }^{21}$ Edmund Husserl, Cartesianische Meditationen, §3, p.49.
} 
cumprimento de exigências nascidas na filosofia de Descartes e que, ainda naquele tempo, esperavam ser levadas a termo.

A necessidade que fará nascer a crítica dos Prolegômenos é exatamente a mesma que será apresentada tardiamente nas Meditações Cartesianas: em sua totalidade, as ciências se reúnem sob uma condição negativa, a saber, aquela que as situa num estado de imperfeição absoluta. Contudo, antes que se possa determinar o significado desta imperfeição, é preciso ter em vista que ela não se confunde com incompletude. Embora uma ciência esteja aqui impedida de sustentar o predicado de perfeita, ela ainda é capaz de efetuar ações das mais complexas e cumprir seus objetivos, sem que a completude de sua técnica esteja ameaçada por sua imperfeição. Prova disto são as próprias matemáticas: mesmo incônscio do que possa vir a ser a perfeição de uma ciência, o matemático ainda é capaz de executar sua tarefa, progredir na obtenção de resultados, propor as operações científicas significativas e aplicar métodos de maestria incomparável. Então, se não é ali, no coração das operações, onde se situa a constrangedora "condição imperfeita de todas as ciências?" Esta ubíqua imperfeição encontra-se naquilo que Husserl denominará de privação "da evidência dos fundamentos últimos de seu fazer" 22 . Esta privação é uma mácula comum a cada uma das ciências: todas elas encontram-se num estado permanente de carência, não no que diz respeito às verdades de suas regiões, mas ao que se refere aos seus pressupostos fundamentais. As ciências são entendidas como imperfeitas porque ignoram por completo os princípios e normas responsáveis por conferir, em última instância, cientificidade às próprias ciências. Daí o reconhecimento pouco animador de que as diletas expressões da razão jazem "na falta de claridade e racionalidade, as quais nós devemos exigir independentemente de sua extensão"23. Assim sendo, se as ciências não são capazes de observar aquilo que lhes está na base, já pouco importa que possam avançar de maneira irrefreável. Para serem dignas do nome que carregam, elas não podem ser menos do que diáfanas quanto os seus pressupostos. É deste modo que a exigência de recuperação da racionalidade, à qual Husserl se refere, passa a figurar como tarefa das Investigações Lógicas: nas ciências nada pode restar pressuposto e nenhum conceito pode

\footnotetext{
${ }^{22}$ Edmund Husserl, Prolegomena, §4, p. 10.

${ }^{23}$ Idem, Ibidem.
} 
operar em região nublada; todo empenho da reflexão deve estar voltado em conferir-lhes claridade, em fazer delas kristallklare Theorien ${ }^{24}$.

Neste sentido, esclarecer os fundamentos das teorias aponta para a investigação de um método generalíssimo, responsável pelo desenvolvimento e pela regência dos campos científicos em suas particularidades. A apresentação do método é o que vai enunciar a essência da teoria e permitir descrevê-la sob a forma de uma teoria das teorias. Mas, afinal, em que consiste esta teoria capaz de conferir cientificidade às ciências? A resposta ofertada à questão somente pode ser compreendida a partir das núpcias que Husserl consuma com a filosofia leibniziana ${ }^{25}$. Muito além de um mero semblante laudatório, Leibniz é rememorado nos Prolegômenos devido a uma tese que é, em larga medida, responsável pela concepção de uma teoria das teorias. Husserl irá se referir a ela da seguinte maneira:

"Sua formação como uma disciplina de forma e rigor matemático, como matemática universal no mais elevado e no mais amplo sentido, é um objetivo ao qual sempre se empregam esforços". ${ }^{26}$

Esta nova espécie de matemática universal se definirá nos Nouveaux Essais como argumenta in forma, isto é, uma doutrina geral da própria argumentação, cuja amplíssima generalidade a remetia a todo raciocínio "par la force de la forme". Por meio dela, Leibniz pretendia deixar claro que a nova doutrina não atendia somente a um domínio específico da razão, mas que estava assegurada para todos eles - desde as análises matemáticas dos infinitesimais, passando por simples cálculos algébricos e chegando finalmente à teoria dos contos. Definida como "a forma das coisas em geral”, esta doutrina matemática não mais se restringia ao sentido habitual do tratamento da quantidade (de formulis ad quantitates applicatis, sive de aequali et inaequali, "sobre as fórmulas aplicadas às quantidades ou sobre o igual e o diverso"), mas se debruçava sobre a determinação da qualidade (de qualitate in genere sive de simili et dissimili, "sobre a qualidade em geral ou sobre o símile e o dissimile"). Mais do que simplesmente diferenciar, Leibniz também as hierarquizava: álgebra e geometria deviam obediência incondicional à chamada ars combinatoria, uma vez que as teorias da quantidade serviam-se continuamente das regras

\footnotetext{
24 "Elas [as ciências] não são teorias claras [kristallklar], nas quais a função de todos os conceitos e proposições seriam completamente compreensíveis, todos os pressupostos seriam completamente analisados e assim o todo estaria acima de toda dúvida teórica". Idem, Ibidem.

${ }^{25} \mathrm{Cf}$. Marcus Sacrini, The making of phenomenology as an autonomous discipline, p. 210.

${ }^{26}$ Edmund Husserl, Prolegomena, §60, p.220.
} 
estabelecidas pela doutrina da qualidade, quer dizer, segundo o juízo leibniziano, jamais poderia haver matemática convencional cujo exercício estivesse privado das formas de expressão a priori da doutrina da combinação.

Ao ser concebida deste modo, a doutrina de Leibniz configurava um duro golpe a Descartes. O exame detido da matemática universal (como tarefa de construção de uma lógica reformada) consistia em tratar, de forma mais fundamental, aquilo que as Meditationes tomavam como um pressuposto, num contra-senso de seus princípios e exigências. A fim de fazer valer o motivo que impulsionava a filosofia moderna ("a idéia

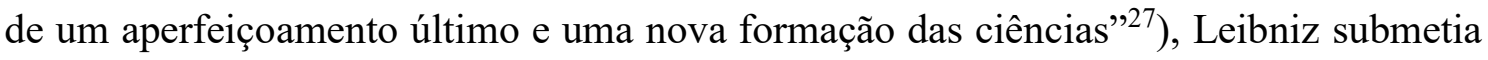
as noções do pensamento cartesiano ao preceito da eversio: trazendo o fundo à tona, a geometria lineariter ad veterum morem tractata ("geometria tratada linearmente conforme o antigo hábito") já não aparecia sob a forma ideal de recuo último que fornecia as condições objetivas do conhecimento válido, mas era originária de uma forma mais fundamental, a ars combinatoria. Ao encontrar uma determinação mais clara et distincta para a própria dedução, pressuposta até mesmo pela geometria, o que Leibniz propunha era uma mathesis universalis em sentido mais vasto e amplo, dada totalmente a priori.

A solução de Leibniz para a questão da condição objetiva das ciências tem seu valor reconhecido por Husserl em sua investigação sobre a essência da teoria. Com efeito, os Prolegômenos afirmavam que as leis de relação (ou "leis de complicação" de uma ciência da quantidade em geral), entendidas sem qualquer modificação em relação à evidência de seu conteúdo nos Nouveaux Essais, também pertenciam, ainda que de modo muito particular, ao âmbito de sua pesquisa. De modo muito particular porque ali, por mais que tivessem importância e lugar reconhecidos, estas "leis de complicação" não pareciam estar imunes aos efeitos eversio husserliana. De fato, ainda que certo tom de louvor se conservasse, uma vez mais a obdurada orientação de recavar os fundamentos fazia rivalizar filósofos que honravam um preceito comum. Por uma exigência de princípio, Husserl iria então submeter Leibniz às mesmas condições que este submetera Descartes, forçando a provar o gosto amargo de sua famigerada proposição (“o senhor Descartes ia rápido demais" ${ }^{28}$ ): embora a ars combinatoria se apresentasse como uma teoria puramente ideal, suas formas elementares de ligação das proposições (die elementaren Verknüpfungsformen von Sätzen) ainda dependiam de conceitos mais gerais

\footnotetext{
27 “Die Idee einer Vervollkommnung und Neugestaltung der Wissenschaften". Idem, Ibidem, p. 221.

${ }^{28}$ Cf. Gérard Lebrun, David Hume no álbum de família de Husserl, in: A filosofia e sua história, p. 254.
} 
e, portanto, fundamentais. "Naturalmente estas leis de complicação, que possibilitam a visada combinatória sobre os conceitos deduzidos com base em conceitos e formas primitivos, e a visada combinatória ela mesma também pertencem ao círculo de pesquisa aqui considerado" 29 . Não parecia haver erro, dado que a tese leibnziana, apesar de tudo, estava depositada "sobre o solo daquela idéia de lógica pura" 30 ; havia imperfeição porque lhe faltava profundidade. Saná-la, através de uma resposta autêntica e definitiva à questão da essência da teoria, convertia-se na tarefa de Husserl.

Se os Prolegômenos então reconheciam a insuficiência das formas de ligação em sua tentativa de explicação última da cientificidade das ciências, era porque bem sabiam que as leis de complicação das proposições eram sustentadas por conceitos mais gerais, ou seja, tornava-se evidente que as formas de ligação elementares eram deduzidas de conceitos primitivos generalíssimos, dos quais não era mais possível recuar. Isto significa que a teoria das teorias seria enfim desvelada caso a seguinte pergunta fosse respondida: o que são estes conceitos primitivos? Para Husserl, os conceitos primitivos em sua totalidade constituem a idéia de uma unidade teórica fundamental e normativa em relação a toda e qualquer teoria, quer dizer, eles constituem a estrutura fundamental ou a essência da própria dedução. É assim que a elucidação da forma da teoria em geral dependerá da clarificação destes "simples conceitos" (ou conceitos primitivos da dedução ela mesma), cuja generalidade incomparável permite a instituição das ciências particulares. Deste modo, para que uma ciência possua o direito de se proclamar verdadeiramente “científica”, ela não pode se furtar aos "conceitos de 'conceito', 'proposição', 'verdade' etc."; noutros termos, nenhuma ciência pode se privar de "categorias de significação" ou "categorias puras (formais) objetivas" ${ }^{31}$. Daí se compreende como a eversio que Leibniz aplicara à filosofia de Descartes era essencial, porém limitada: as formações dedutivas mais complexas das proposições (conjuntiva, disjuntiva, hipotética, etc.) não esgotavam o recuo às condições objetivas que concediam cientificidade às ciências. Para fazê-lo, exigiam-se conceitos ainda mais distintos, cujo tratamento era reivindicado por um conhecimento agora sim fundamental, responsável pela investigação da essência da teoria. Essa pura "teoria das teorias", sem a qual teorias em geral não teriam "nenhum

\footnotetext{
${ }^{29}$ Edmund Husserl, Prolegomena, §67, p. 243-244.

${ }^{30}$ Idem, Ibidem, $\$ 60$, p. 222.

31 "Dahin gehören schon die Begriffe: Begriff, Satz, Wahrheit, usw.". Idem, Ibidem, §32 e §67, p. 111 e 243-244.
} 
sentido 'racional' (consistente)"32, será batizada por Husserl de ars inventiva ou lógica pura.

Delimitada a região de atuação da lógica pura, Husserl entrevê a necessidade de definir aquele que dela deve se ocupar. Para tanto, os Prolegômenas instauraram uma "divisão do trabalho" (Arbeitsteilung) muito precisa no interior da teoria das ciências: por razões concretas, os matemáticos devem se ocupar da ars inventiva. Mas em que consiste esta concretude que leva o filósofo a delegar aos matemáticos a exclusividade de tratamento dum campo que sempre fora privilégio da filosofia? Ainda que investigada em um sentido não completamente puro, é sabido que os matemáticos já se dedicavam a uma matemática formal, a qual contava entre seus elementos com alguns traços presentes na teoria geral das ciências. Ora, conceder-lhes o direito de lidar com a lógica pura não significava outra coisa que reconhecer a desenvoltura com a qual poderiam lidar com as questões por ela suscitadas. Afinal, sempre - acentua Husserl - foi um domínio matemático por excelência a dissolução de problemas formais. Mesmo as teorias silogísticas, "supostamente há muito acabadas", foram não somente reivindicadas pelos matemáticos como também conheceram, sob seus cuidados, grande desenvolvimento. "Ninguém pode proibir os matemáticos de exigir para si tudo aquilo que deve ser tratado segundo a forma e o método matemático" 33 . Estejam ou não os lógicos filosóficos de acordo com tal atribuição, fato é, dirá Husserl, que a essência da dedução, enquanto forma e condição objetiva de toda teoria, é e deve permanecer tarefa dos matemáticos. A crença ingênua de que o fundamento da matemática repousa nos conceitos de número e quantidade deve ceder lugar ao reconhecimento do depurado exercício matemático, ou seja, do trato e conservação da lógica pura.

\section{III - As condições subjetivas}

Quando a teoria das teorias encontra-se sob os cuidados dos matemáticos, o que resta ao filósofo? Estaria ele fadado a depor sua pena e cessar seu trabalho, dado que a figura do matemático surgia como mais adequada à lida com a nova mathesis universalis? Certamente não. Era uma mera suposição, surgida com o pré-juízo cartesiano de assumir a geometria como ciência ideal, que vinculava o destino do filósofo ao destino da mathesis

\footnotetext{
${ }^{32}$ Idem, Ibidem, §32, p. 112.

${ }^{33}$ Idem, Ibidem, §71, p. 252.
} 
universalis de maneira indissociável. Por isso, se Husserl o apartava da lógica pura, era porque originalmente aquela não era sua morada e as condições objetivas do saber não eram sua ocupação. A tarefa da filosofia, longe de se atrelar às objetividades formais, deveria recobrar aquilo que the coubera e desempenhar seu papel primevo. E era justamente através dum preceito grego que Husserl relembrava ao filósofo sua função:

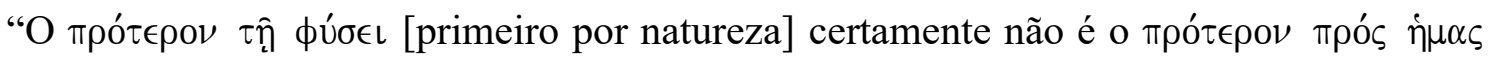
[primeiro para nós]"34. Afirmar, assim, que o mais próprio da filosofia está em investigar

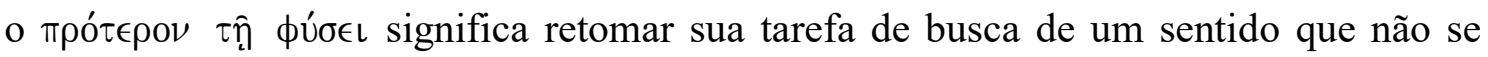

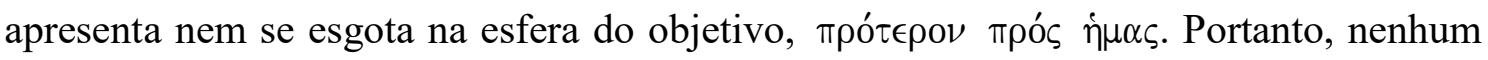
estranhamento deve se manifestar pelo fato do filósofo estar alheio ao estudo das puras formas e leis associadas à cientificidade das ciências, pois sua atividade autêntica não reside na observância da essência da dedução (isto é, a lógica pura), mas na clarificação de seu sentido, expresso por um conhecimento essencial de outra ordem. E qual não será a boa e frutífera surpresa do filósofo, notará Husserl, ao compreender que tal essência encontra-se numa wunderbare Affinität com a essência do pensar (Wesen des Denkens). É neste encontro que a reflexão filosófica se define exclusivamente como gnosiológica e dedica-se a descrever as "condições ideais que se enraízam na forma da subjetividade em geral e em sua relação com o conhecimento" 35 .

Não havia, deste modo, nenhum menoscabo no afastamento do filósofo do domínio da lógica pura. Na verdade, ao reavivar sua figura como o responsável pela clarificação das condições noéticas, Husserl lhe designava uma tarefa que os estudiosos da mathesis universalis jamais poderiam cumprir. Sendo o matemático apenas uma espécie de "técnico engenhoso" 36 , restrito à observação das unidades formais edificantes das teorias, ele nunca alcançaria a condição legítima de um teórico puro; ainda que sua disciplina fosse capaz de elucidar eideticamente a forma da dedução, ela conservava um silêncio sepulcral com respeito à essência subjetiva que fundamenta a teoria das teorias. Em outras palavras, por mais que o matemático assegurasse sua dignidade científica ao operar com as leis universais da lógica pura, irretorquíveis baluartes da objetividade, a verdade é que, ainda assim, ele estava condenado a jamais produzir qualquer juízo sobre as condições subjetivas do conhecimento. Enquanto matemático, não poderia atestar a verdade e a objetividade de seu próprio saber; restringia-se à "teoria das teorias" e não

\footnotetext{
${ }^{34}$ Idem, Ibidem, p. 253.

${ }^{35}$ Idem, Ibidem, §32, p. 111. Idem, Logische Untersuchungen II/1, Einleitung, §2, p. 4.

${ }^{36}$ Idem, Ibidem.
} 
avançava ao âmbito da "teoria do teorizar"37. Era no abismo que se abria entre a possibilidade da lógica pura de tratar com justeza das condições objetivas e sua impossibilidade de legislar sobre as condições subjetivas do conhecimento que a figura do filósofo surgia em sua máxima força: uma vez que a teoria das teorias não podia apreender o modo pelo qual uma verdade era colocada, tinha ele o dever de fundamentála num conhecimento puro e autenticamente teórico que a livrasse deste ponto cego. Neste sentido, filósofo e matemático jamais rivalizaram nos Prolegômenos. Pelo contrário: na divisão do labor, a crítica do conhecimento estava ali para fornecer à lógica pura um solo subjetivo que ela não podia desvelar por seus próprios meios; e a lógica pura lá estava para emprestar à crítica do conhecimento as leis regentes da teoria em geral, na finalidade de que ela pudesse se estabelecer como teoria do teorizar. Tanto o filósofo quanto o matemático estavam além da vacuidade da peleja que se promovia entre regiões fundamentais do saber; na verdade, estavam imbuídos da responsabilidade para com a perfeição das ciências. Por este motivo, Husserl se permitia afirmar que "a ars inventiva do lógico puro (Spezialforschers) e a crítica de conhecimento do filósofo são atividades científicas complementares, através das quais se realiza um saber teórico completo e abrangente de todas as relações de essência" 38 .

Mas se as condições objetivas já se encontravam bem delineadas no interior da complementaridade da tarefa, faltava ainda descrever de modo mais detido para onde apontava a atividade filosófica. O que eram, portanto, as ditas condições subjetivas? $\mathrm{O}$ que significava fundar uma teoria do conhecimento? Em sua determinação mais profunda e rigorosa, a teoria do conhecimento era a resposta à necessidade de clarificação dos pressupostos, dada em seu contorno "puramente abstrato" (rein begrifflich). No teutônico jogo de palavras de Husserl, as condições subjetivas são o Wissen (saber) que fundamenta a própria Wissenschaft (ciência). Mas, afinal, o que era - agora numa terminologia cartesiana e mais familiar - o scire que estava na base da scientia? Sempre siderado pelo preceito da eversio, Husserl estava fadado a entender que sob a rubrica do saber não se depositava nenhuma convicção cega ou vaga opinião: opondo-se à mera crença, ele era $a$ certeza luminosa (die lichtvolle Gewißheit) que nos permitia conhecer imediatamente o dado. O saber era, a bem dizer, a evidência de tudo que se desvelava, a doação originária

\footnotetext{
${ }^{37}$ Cf. Bruce Bégout, La réverbération logique, p. 584.

${ }^{38}$ Edmund Husserl, Prolegomena, §71, p. 254. Sobre o tema da complementaridade existente entre condições objetivas e condições nóeticas cf. Javier Y. Alvarez-Vásquez, Husserls 'Allgemeine Erkenntnistheorie' von 1902/03. Zur Frühentwicklung der phänomenologischen Methode; Marcus Sacrini, The making of phenomenology as an autonomous discipline.
} 
do visado. Se então a evidência aparecia nestes trajes confeccionados à época de Descartes, numa espécie de prova das honras desprendidas ao preceito que colocava a filosofia em curso, não era de se estranhar que Husserl a descrevia numa passagem que nada devia à retórica das Meditationes: “A perfeitíssima (vollkommenste) marca da certeza é a evidência; ela vigora para nós como o interiorizar imediato da verdade mesma" ${ }^{39}$. E era ela "perfeitíssima" porque ciência alguma podia dela prescindir e mesmo a teoria das teorias devia-lhe respeito, uma vez que a determinação da evidência era a determinação do próprio saber; todo conhecimento a pressupunha e sobre ela repousava, visto que ali onde "a evidência se estende, estende-se também o conceito do saber". ${ }^{40}$ Contudo, esta terna remissão à certitudo de Descartes parecia cessar de modo tão abrupto quanto surgia - e por conta de um motivo já bastante conhecido. Husserl parecia aceitar de bom grado (pois isto não escapava ao rigor) que, em seu curso natural, a eversio desembocava no primado da certeza. O que, todavia, lhe soava perturbador era como o genial vislumbre inaugural desvanecia devido a uma ingenuidade pueril que ignorava o próprio postulado. Quando as Meditationes supunham a geometria como um ideal de ciência, elas apagavam a fronteira que separava os territórios da evidência e da dedução; o rectum veritatis iter (“o reto caminho da verdade"), que fazia a certitudidem Arithmeticis et Geometricis demonstrationibus aequalem ("certeza igual às demonstrações aritméticas e geométricas") ${ }^{41}$, reunia confusamente sob a nomenclatura de mathesis universalis as condições ideais objetivas e subjetivas das ciências. Descartes, por assim dizer, não separava o joio do trigo. Se este era o caso, para Husserl não parecia haver sentido algum em sacrificar toda clareza que se desenhava ao longo do Prolegômenos em favor de uma mera cortesia ou de uma conservação laudatória. $\mathrm{Na}$ verdade, não parecia haver panegírico mais solene a ser proferido do que aquele de uma eversio atuante e da subseqüente correção de um erro. E a "correção" encontrava-se justamente no reconhecimento e na contemplação da evidência como uma origem legítima, isto é, como uma subjetividade completamente depurada dos resquícios objetivos que a pressuposição cartesiana do ordo nela insistia em imiscuir. Quando a mathesis se deixava circunscrever única e exclusivamente à esfera objetiva, submetida aos cuidados dos matemáticos, a subjetividade podia enfim aparecer sem nenhum tipo de

\footnotetext{
${ }^{39}$ Idem, Ibidem, $\S 6$, p.13.

${ }^{40}$ Idem, Ibidem.

${ }^{41}$ René Descartes, Regula ad directionem ingenii, Regula II, p. 12; Meditationes, Med. II, Synopsis, p. 3638 .
} 


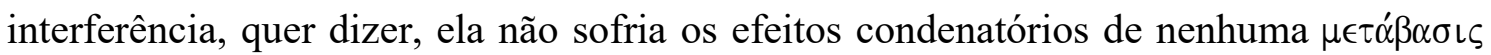

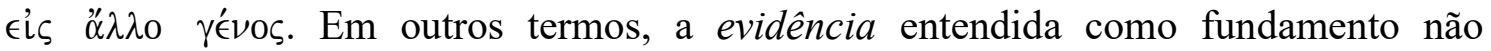
significava outra coisa que o encontro com a dita origem fenomenológica (die phänomenologische Ursprung) ${ }^{42}$.

Daí que o filósofo, quando fazia da investigação da origem seu ofício, convertiase em fenomenólogo. Fenomenólogo, nunca psicólogo - Husserl fazia questão de acentuar. E por que não psicólogo? Que preocupação era esta que o acometia e o conduzia a distinguir a fenomenologia, já em sua aurora, de uma disciplina que parecia compartilhar seus interesses em descrever aquilo que se encontrava arraigado nos arcanos da subjetividade? A resposta para esta questão ultrapassava os limites dos Prolegômenos para se situar na Quinta Investigação Lógica. Ali, ao desdobrar o tema da "evidência" no trato detido do campo das vivências, Husserl ensinava o que era uma vivência puramente fenomenológica. Sua definição trazia como marca de princípio a passagem pelo negativo, quer dizer, iniciava-se a descrição do que é uma vivência fenomenológica a partir daquilo que ela não é. E ela certamente não é sua homônima "vivência psicológica". Se é assim, o que norteava a investigação fenomenológica das vivências, num primeiro momento, era a pergunta: o que é uma vivência psicológica? Para as Investigações Lógicas, uma vivência psicológica era, antes de tudo, um conceito popular e, por isso mesmo, pouco rigoroso ${ }^{43}$. Sua "vulgaridade" consistia em tomar a vivência empiricamente, enquanto uma unidade formada por um quinhão psíquico e outro objetivo, que nela participava naturalmente (natürlich), constituindo-lhe parte indissociável. Era por esta característica formação de unidade que a vivência psicológica compreendia-se como um conter (Haben) da coisa (para a qual o ato se lançou) no ato (que se lança a tal coisa), ou seja, a vivência entendida psicologicamente não era senão um acontecimento real (reales Vorkommnis) sempre mutável, cuja coesão das ininterruptas sucessões tomava a forma de um sujeito psíquico ou um Ego, centro das relações subjetivas. Se então o ser da vivência psicológica jazia naquela harmoniosa conjunção entre o psíquico e o físico, o não-ser-psicológica - dirá Husserl - entrava na cena fenomenológica com a função muito específica de negar aquele Haben: a vivência fenomenológica só é fenomenológica porque, ao ser visada, ela não contém coisa alguma, ela é tomada em si, sem implicar na recorrência à 'impropriedade do discurso do 'estar contido' intencional do objeto no

\footnotetext{
${ }^{42}$ Edmund Husserl, Prolegomena, §67, p. 244

43 "Com a mesma intenção, nós ainda indicamos que nosso conceito de vivência não concorda com conceito popular (...)". Edmund Husserl, Logische Untersuchungen, V, §3, p.351
} 
ato" ${ }^{\text {44 }}$. Isto significava que, uma vez subtraída a coisa ao ato, já não era esperado da investigação que se movesse no âmbito do particularismo empírico, mas que se deslocasse ao terreno do a priori, no qual as vivências deveriam ser estudadas em sua pureza ideal: "agora é indicado que este conceito de vivência deixa-se apreender de maneira puramente fenomenológica, isto é, que toda relação com o ser empírico-real (homens ou animais da natureza) esteja excluída" ${ }^{45}$. O que fazia a fenomenologia era iniciar uma purga radical que instaurava sua própria esfera por meio da condenação e do rebaixamento da psicologia de sua condição de ciência (aparentemente) rigorosa à condição de "um equívoco muito prejudicial" (eine sehr schädliche Äquivokation). Em face da vivência fenomenológica, não conspurcada por elementos reais, a "vivência" psicológica não passava de um extravio conceitual, operando na superfície da subjetividade e disseminando o erro mais básico de suposição de equivalência entre o aparecer da coisa e a coisa que aparece - isto é, ignorando que o objeto jamais será um elemento consciente (bewußt) e, por este motivo, não fará parte da análise da consciência (Bewußt-sein).

E era exatamente no sentido da observação da vivência apartada da coisa que a fenomenologia se definia como não-natural. Uma ausência de naturalidade que não se dava por obra do acaso, é verdade, mas que refletia a própria essência da filosofia da eversio. Ela era a fuga do hábito envolta por uma férrea determinação do filósofo, uma espécie de teimosia que o impedia de esboçar qualquer retorno ao real e, com isto, comprometer sua tarefa. Ora, tratava-se de uma orientação que Descartes já anunciava no limiar das Meditationes:

"Mas ainda não é suficiente que tenha notado essas coisas, devo cuidar de me lembrar delas, pois as opiniões costumeiras reaparecem ininterruptamente, a ocupar minha credulidade, a elas submetida quase contra minha vontade por um demorado trato e um direito de familiaridade (...) [Que] nenhum mau hábito em larga medida desvie meu juízo da reta percepção das coisas" ${ }^{46}$.

E que Husserl repetia de maneira nada canhestra em suas Investigações Lógicas:

\footnotetext{
${ }^{44}$ Idem, Ibidem, V, §11, p. 375.

${ }^{45}$ Idem, Ibidem, V, \$2, p. 348.

46 "Sed nondum sufficit haec advertisse, curandum est ut recorder; assidue enim reccurunt consuetae opiniones, occupantque credulitatem meam tanquam longo usu et familiaritatis iure sibi devinctam, fere etiam me invito (...) Nulla amplius prava consuetudo iudicium meum a recta rerum perceptione detorqueat". Descartes, Meditationes, Med. I, §11, p.30.
} 
"Um sentido do pensar que é contrário aos hábitos mais fixos e que se intensificam desde o começo do nosso desenvolvimento psíquico"47.

A análise fenomenológica das vivências nascia assim sob o signo da convicção empedernida e empenhada em evitar a tentação de recorrer, qualquer que fosse $o$ momento, à naturalidade das coisas - o que, no caso de uma investigação sobre a consciência, significava a apreensão do ato em seu aspecto empírico, aos moldes da psicologia. Mas se o fenomenólogo estava impossibilitado por uma postura originária de recorrer à visada real do ato, como era esperado que ele pudesse se dirigir à consciência? Para evitar o raso de uma subjetividade impura, afirmava Husserl, era necessário refletir. E a reflexão, quando fenomenologicamente compreendida, não era senão um tipo muito característico de percepção: não aquela que se lançava à imediatidade fática e apreendia os objetos através de inesgotáveis silhuetas passíveis de sínteses, mas uma percepção interna das próprias vivências, dadas intuitivamente. Dito de outro modo, esta percepção interna, enquanto um dobrar-se da consciência sobre si mesma, entendia-se como uma adäquate Wahrnehmung (percepção adequada). Refletir significava então situar uma adaequatio no cerne das Investigações Lógicas? De fato ela lá se encontrava, mas nada tinha a ver com a já datada adaequatio intellectus et rei, pois, à diferença de Brentano, Husserl não conservava nenhuma inclinação aristotélico-tomista. Sem qualquer teor escolástico, a adaequatio aparecia para a fenomenologia como um momento fundador, no qual a visada voltava-se diretamente $(\mathrm{ad})$ para si mesma enquanto visada (aequare), obtendo em função deste retorno (que não é senão uma "visada do mesmo", um adaequare) o objeto em toda sua clareza. A adaequatio, portanto, designava a perfeição de uma intenção na doação de uma vivência para si mesma, no rigoroso sentido da manifestação em "carne e osso" 48 , ou seja, uma doação da totalidade das reentrâncias, na inigualável presentificação do dado absoluto e sem restos a serem doravante acrescentados.

Mas este encontro da subjetividade consigo mesma não era uma tese já proferida por Descartes? A percepção adequada e pura não era apenas um outro nome para aquele ego resistente à dúvida hiperbólica das Meditationes? Certamente não. Antes que uma comparação deste gênero pudesse ter lugar, Husserl fazia questão de acentuar que sua eversio suprimia, entre outras noções propostas pelo cartesianismo, seu estimado ponto

\footnotetext{
${ }^{47}$ Edmund Husserl, Logische Untersuchungen, II/1, §3, p.10

${ }^{48}$ Idem, Ibidem, V, §5, p. 355.
} 
arquimediano, ou seja, o próprio ser do ego: "No juízo eu sou a evidência encontra-se em um certo núcleo (não limitado à agudeza abstrata) da representação empírica do eu" "49 . A ruptura que estas palavras provocavam no fundamento das Meditationes era impiedosa e irremediável. Nada poderia ser mais preocupante ao ego - e com isto até mesmo Descartes seria obrigado a consentir - do que uma acusação de insuficiência abstrativa, prova cabal da limitação de sua eversio. Que a abstração do ego cartesiano fosse insuficiente, significava que ele transgredia os limites da descrição pura das essências em direção a um juízo que, desde o início, já supunha uma representação empírica de si. Impondo-se pela transgressão, o ego em nada diferia, aos olhos de Husserl, de uma coisa qualquer dada à consciência: "o eu é percebido do mesmo modo que qualquer coisa externa" ${ }^{50}$, não conservando nenhuma pureza em sua investigação, visto que a apreensão da vivência não era adequada, mas supunha um juízo já constituído como fundamento constituinte. Assim sendo, já não se podia conferir ao ego uma posição que não lhe era de direito, a saber, aquele posto primeiro e absoluto na estruturação de uma teoria do conhecimento. Daí que, a cada passo dado em sentido da clarificação do fundamento, fazia-se mais notória a necessidade de abandonar uma concepção de subjetividade que conservava um ego real em detrimento da visada pura. E Descartes, antes de ser elogiado por ter elucidado a questão, era repreendido por sua incapacidade de reconhecer que "no juízo eu sou, sob o eu, o percebido adequadamente (das adäquat Wahrgenommene) constitui o núcleo que fundamenta e possibilita antes de tudo a evidência"51. Afinal, ali, "sob o eu", onde a abstração propiciada pela fenomenologia permitia chegar, não se conservava nenhum dado de "eu puro residual" enquanto uma doação adequada do ego. Caso este mesmo ego fosse considerado (em seu semblante real) como uma unidade de consciência, todo o sentido fenomenológico da análise desvaneceria e tomaria seu lugar uma análise nada rigorosa da "dignidade da coisa física" 52 . Não era de se estranhar, portanto, a posição receosa que a fenomenologia mantinha em relação à primazia do ego: nas Investigações Lógicas, o conceito cartesiano não passava de uma degeneração metafísica da apreensão adequada e pura do dado, um desvirtuado que colocava a perder a esfera das vivências que mal acabara de desvelar. A eversio que Husserl fazia ali atuar cumpria seu papel ao

\footnotetext{
${ }^{49}$ Idem, Ibidem, V, §6, p. 357.

${ }^{50}$ Idem, Ibidem, V, §8, p. 362.

${ }^{51}$ Idem, Ibidem, V, $\$ 6$, p. 357.

52 "O eu empírico possui a mesma dignidade da coisa física. A exclusão desta transcendência e a redução ao dado puramente fenomenológico não conserva nenhum eu como resíduo, não podendo assim doar nenhuma evidência efetiva (adequada) 'eu sou'”. Idem, Ibidem, V, §6, p. 357. (cf. também §12b, p. 377).
} 
rememorar à caterva cartesiana que o ego, antes de ser o fundamento que fornecia sentido às Meditationes, era o mais profundo desrespeito ao preceito fundador da ausência de pressupostos. E mais: lembrava também que por maior que tenha sido a insistência de Descartes em se manter numa atitude meditativa, sucumbia ele às provações do laboriosum institutum ("laborioso propósito"), retrocedendo à consuetudo vitae ("hábito da vida") em que vigorava desidia quaedam (“uma desídia qualquer") 53 .

Mas, se a proposta cartesiana mostrava-se insuficiente, o que a abstração fenomenológica apresentava como a forma de uma subjetividade em geral? Husserl encontrava no fluxo de consciência a resposta para a questão da coesão fundamental das vivências. Doação adequada e, portanto, apodítica, a forma da subjetividade enquanto fluxo era menos devedora da rigidez do ego cartesiano do que daquele movimento expresso por Heráclito em seu aforismo:

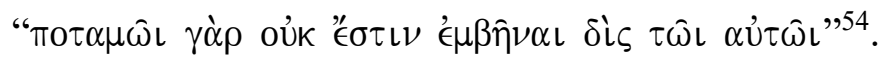

Esta inspiração heraclítica fazia da forma da consciência um todo fenomenológico nãoestático ou, como Husserl o batizara, uma unidade de modificação, por meio da qual se compreendia a sempiterna renovação das vivências na simultânea preservação de sua forma geral. Como num rio, em que a água corrente jamais é a mesma, as vivências serão sempre variáveis na consciência, dadas como momentos determinados; e, ainda como num rio, em que a forma se conserva não obstante o correr de suas águas, a consciência mantém-se como a unidade do todo, um fluir constante das vivências sempre variáveis. Se então o fundamento último é o fluxo de sucessão das vivências, pode-se bem dizer que ele não é senão uma temporalidade imanente: nada tendo a ver com o "tempo do mundo" (sendo, em última instância, apenas "temporalidade" por homonímia, pois não se remete à temporalidade das coisas), surge como aquilo pelo qual "o fluxo de consciência mesmo manifesta-se, no qual ele flui" ${ }^{55}$. Ou nas esclarecedoras palavras de Lebrun, o fluxo é para Husserl (como será o para-si para Sartre) aquilo que se opõe ao ego como um centro de

\footnotetext{
53 "Sed laboriosum est hoc institutm et desidia quaedam ad consuetudinem vitae me reducit" ("Mas este propósito é laborioso e uma certa desídia devolve-me à vida de costume"). René Descartes, Meditationes, Med. I, §13, p. 32.

54 "Não se pode entrar duas vezes no mesmo rio". Diels-Kranz, Die Fragmente der Vorsokratiker, Wiedmannsche Verlagsbuchhandlung, Berlin, 1960. Heraklit, Fr. 91, p. 171.

${ }^{55}$ Edmund Husserl, Logische Untersuchungen, II/1, V, §6, p. 358.
} 
relação fixo; o fluxo "é apenas um desabrochamento sem origem, se quisermos empregar uma [outra] imagem"56.

\section{IV - A orientação natural}

Em seu Discurso do Método Descartes professava sem receio que a razão "é por natureza igual em todos os homens" ${ }^{" 57}$. E ela assim o será, na conservação de sua equidade, não obstante as verdades claras e distintas sejam apreendidas em diferentes intensidades ou sejam simplesmente ignoradas. Afinal, que alguns sejam capazes de visar plenamente estas verdades enquanto outros sequer podem concebê-las num mínimo grau, isto em nada diz respeito a uma espécie de desequilíbrio distributivo da faculdade do conhecimento. Na verdade, antes que se pudesse levantar a suspeita de que certos homens eram dotados de uma razão minguada, Descartes já alertava que o reconhecimento de uma vista turvada às verdades não condizia com uma razão atrofiada, mas encontrava sua causa na conservação de pressupostos irrefletidos na construção dos saberes. Era justamente sobre esta questão que os Principia Philosophiae não cansavam de nos rememorar:

"Não creio, no entanto, que a faculdade de conhecer de um homem seja dada de maneira mais ampla do que a de outro; isto porque estas noções comuns [i.é, as verdades] contrastam com as opiniões prejudicadas de certos homens, que por isso não podem apreendê-las facilmente - ainda que alguns outros, que são livres destes prejuízos, percebam-nas de modo muito evidente" ${ }^{\text {58. }}$.

Se então a dificuldade de apreensão de verdades claras e distintas já não estava associada à extensão da razão, mas consistia num impedimento promovido por "opiniões prejudicadas", o justo trato com estas "noções comuns axiomáticas" não mais dependerá de supostas capacidades inatas e sim de uma purgação da própria razão por meio da exclusão de seus pressupostos. Ora, esta tese cartesiana, como bem se sabe, gozará de boa fortuna na fenomenologia. Ainda que atuante e perceptível aos mais atentos leitores dos

\footnotetext{
${ }^{56}$ Gérard Lebrun, As palavras ou os preconceitos da infância, in: A filosofia e sua história, p. 51.

57 René Descartes, Discurso do Método, p. 5.

58 "Non tamen, ut puto, quod unius hominis cognoscendi facultas latius pateat quam alterius; sed quia forte communes istae notiones adversantur praeiudicatis opnionibus quorundam hominum, qui eas idcirco non facile capere possunt: etiamsi nonnulli alii, qui praeiuduciis istis sunt liberi, evidentissime ipsas percipiant". René Descartes, Principia Philosophiae, §50, p. 24.
} 
Prolegômenos, era nas Investigações Lógicas que o "princípio da exclusão de pressupostos" fazia sua expressa aparição na cena filosófica husserliana. Afirmava-se ali que a necessidade de assegurar o rigor das investigações passava obrigatoriamente pela exclusão de todos os saberes que não se provassem próprios do território da fenomenologia. E por um território propriamente fenomenológico Husserl compreendia, neste momento, uma consciência alheia a qualquer remissão ao âmbito fático e às suas leis naturais. A fenomenologia deveria comportar-se, portanto, como uma meditação "pura" acerca do sentido do conhecimento - e para isto carecia respeitar a "rigorosa exigência" do preceito cartesiano recuperado, a fim de que pudesse ofertar um "saber evidente" sobre "a intuição de essência" do pensamento segundo seus elementos $\operatorname{constitutivos}^{59}$. Desde então, a fenomenologia já não podia acercar-se da psicologia e partilhar de suas teses: na medida em que tergiversava à toda referência empírico-real, Husserl abandonava com ela a compreensão das vivências como fatos individuais; a consciência, tal como ele a entendia, já não apresentava uma singularidade resultante do entrelaçamento com um corpo, mas se propunha uma consciência überhaupt, ou seja, uma subjetividade anônima e em nada devedora de uma consciência de contorno empírico, sempre individualizada. Guiada pelo "princípio da exclusão de pressupostos", a fenomenologia obtinha seu conceito de consciência em geral eliminando toda e qualquer consideração sobre o corpo do eu, "corpo que, como coisa física, aparece como qualquer outra e consideramos o eu espiritual empiricamente ligado a ele, e que se manifesta como a ele pertencente" ${ }^{60}$. E era no momento em que alcançava esta nova subjetividade sem traços psicologistas que ela acreditava ter finalmente cumprido seu leitmotiv de "retorno às coisas mesmas" (zu den Sachen selbst): uma vez apartada do sentido habitual das coisas, a nova disciplina fundada por Husserl via-se livre daquela carga tributária imposta pela psicologia e ensinava que o "retorno às coisas mesmas" não significava senão um retorno ao conhecimento em seu caráter ideal, alheio a toda e qualquer interferência real e seu efeito individualizante ${ }^{61}$.

Mas esta suposta originalidade na circunscrição do subjetivo realmente situava a fenomenologia num território novo em face dos domínios da psicologia? Eis aí uma

\footnotetext{
${ }^{59}$ Edmund Husserl, Logische Untersuchungen, II/1, Einleitung, §7, p.19-21.

${ }^{60}$ Idem, Ibidem, V, §8, p.361.

${ }^{61}$ Com muito acerto afirmava Lévinas: "O regresso aos atos onde se revela a presença intuitiva das coisas é o verdadeiro regresso às coisas. Aí reside certamente o grande choque produzido pelas Logische Untersuchungen". Cf. Emmanuel Lévinas, Reflexões sobre a "técnica" fenomenológica, in: Descobrindo a existência com Husserl e Heidegger, p. 140.
} 
questão que não tardou a ser levantada e que conduziu Husserl a constatar na fenomenologia das Investigações Lógicas uma inobservância que, silenciosamente, ainda se conservava em suas teses: se é verdade que a consciência ali apresentada tinha um caráter ideal, livre da singularidade natural, também é verdade que sua descrição era ainda fiadora de pré-juízos e se submetia à palavra de ordem de Descartes por conta de um motivo bastante específico. E este motivo velado não era outro senão o fato de que a subjetividade até então pensada como original não passava de um residuum do mundo, da mesma maneira que a mens sive animus sive intellectus das Meditationes era um resíduo da abstração do corpo. Por mais que o "princípio da exclusão de pressupostos" se esforçasse em afastar o corpo do cenário fenomenológico, a separação que ele promovia entre o corpo e a alma era uma abstração meramente metódica. ${ }^{62}$ Quando analisada em seus pormenores, aquela recusa das "realidades psicológicas como condições de certas 'essências anímicas' da natureza"63 era apenas uma promessa vazia: se a consciência não era exatamente psicológica graças à sua generalidade, ela não deixava contudo de ser mundana; a distinção estava dada apenas na superfície, visto que a determinação fundamental, existente na unidade concebida entre a alma e o corpo, permanecia ali conservada. Assim sendo, aquela subjetividade fenomenológica das Investigações Lógicas traía a pretensão de pureza da tarefa husserliana porque, em sentido estrito, ela ainda não se diferenciava de uma subjetividade psicológica, quer dizer, ambas não haviam começado suas reflexões "com um conceito de alma criado de maneira completamente original, mas com um conceito descendente do dualismo cartesiano, o qual fora dado através de uma precedente e corpórea idéia de natureza e aos cuidados da ciência matemática da natureza". ${ }^{64}$ Antes que qualquer uma delas alçasse sua voz na reivindicação de originalidade, o que se via era apenas o enraizamento profundo numa orientação clássica do pensar, isto é, uma orientação natural, segundo a qual um mundo externo (Draußen) à vida cogitativa do ego era tomado como algo "tão bem conhecido" que não havia nenhuma razão para que a certeza de seu sentido fosse questionada. ${ }^{65}$

Mas o que era afinal este conceito de mundo que trazia complicações ao primeiro esboço da fenomenologia? O mundo da orientação natural é aquele que se define como o sempre presente (vorhanden), dado anteriormente a toda teoria e independente de

\footnotetext{
${ }^{62}$ Cf. Carlos Alberto Ribeiro de Moura, Husserl: significação e fenômeno, p. 42-43.

${ }^{63}$ Edmund Husserl, Logische Untersuchungen, II/1, Einleitung, p.11.

${ }^{64}$ Idem, Krisis, §58, p. 256.

${ }^{65}$ Idem, Ibidem, §18, p. 82.
} 
uma consciência. No jargão filosófico, dirá Husserl, ele é em si e, enquanto tal, não carece de qualquer atestação subjetiva para que seja efetivamente: o mundo não é relativo a nada e sim uma esfera absoluta, uma "totalidade essencial" (Gesamtinbegriff) ${ }^{66}$ cujas coisas componentes, por princípio, não se reduzem a fenômenos ou manifestações que os trazem à presença, mas conservam a soberania de seu modo de ser, o Seinssinn Objekt. Além disso, o ego também se inscreverá neste mundo como parte de um todo mais amplo que abarca as coisas que ele apreenderá como objetos: "o mundo é sempre 'presente' para mim, e eu mesmo sou seu componente" ${ }^{67}$. O ego e as coisas partilharão assim da condição de regiões de um mesmo mundo, de "uma realidade sempre aí" como um "mundo sempre existente (daseiend) - no sentido da tese geral" ${ }^{\prime \prime 8}$. Portanto, para a orientação natural, o ego não passa de uma região dentre outras regiões no interior da totalidade inescapável do mundo - e que por isso terá, inevitavelmente, um exterior a si. E será este exterior sempre presente que ocupará o posto de condição de possibilidade de todo conhecimento: é a determinação em si do mundo - dado de antemão como um selbstverständlich, como uma obviedade - que permitirá ao ego representar as regiões que além dele e como ele fazem parte deste domínio absoluto. Pois, como dirá Husserl em seu A idéia da fenomenologia, "o impulso ou motivo do pensamento" da orientação natural sempre foi extraído das próprias coisas, “de modo que delas parecessem partir como exigências, as quais colocariam estas doações ao conhecimento"69; na medida em que a autocompreensão do mundo emergia como um sustentáculo inabalável, todo saber seria concebido como um fato. E se para esta orientação jamais se colocou a questão acerca do sentido do mundo, é porque este mundo mesmo sempre figurou como o sentido de toda questão.

Este mundo em si, como contraparte e solo do ego, vigorou com tamanha veemência no curso do pensamento filosófico que Husserl se viu obrigado a confessar que até mesmo suas Investigações Lógicas faziam-lhe justiça. Fato é que ali a reflexão fenomenológica, não obstante pretendesse operar com o conceito de Werk des Durchbruchs ("obra de ruptura"), ainda se movia, desde o princípio, no tradicional terreno da orientação natural. Mas se uma tal concepção de mundo foi capaz de penetrar na própria fenomenologia, resistindo incólume às invectivas da eversio de seu período pré-

\footnotetext{
${ }^{66}$ Idem, Ideen I, §1, p. 11.

${ }^{67}$ Idem, Ibidem, §27, p. 58.

${ }^{68}$ Idem, Ibidem, §30, p. 60.

${ }^{69}$ Idem, Die Idee der Phänomenologie, p. 18.
} 
transcendental, cabe perguntar por qual obra e graça ela passa a ocupar posto tão lisonjeiro. Afinal, por quais vias o mundo recebia a alcunha de em si e tornava-se doravante a condição de possibilidade selbstverständlich de todo conhecimento? Era justamente sobre esta questão que a reflexão histórica da Krisis se debruçava. Ao tratar ali da aspiração à universalidade que sempre existiu na base das ciências, Husserl destacará a maneira pela qual o espaço surge como forma ideal da realidade e concede à geometria seu papel primordial face às outras ciências. Donde então provinha esta primazia e a necessidade de submeter a natureza a uma matematização aos moldes euclidianos? Para responder a questão, Husserl irá nos advertir que, embora consista num hábito profundamente arraigado na compreensão das coisas (por conta da influência cientificista), não passa de ingenuidade supor que o trato com os corpos seja por princípio determinado pela certeza ideal-geométrica. Ao contrário, nada de exato se reconhece na experiência imediata do mundo circundante (Umwelt): as coisas que aí se dão são "mais ou menos retas" ou "mais ou menos planas", sempre reféns da concepção da subjetividade que dela se ocupa e que, por exemplo, faz com que aquilo que seja plano para um não seja plano para outro. Quer dizer, é a relatividade ou gradação (Gradualität) que irrompe como a marca distintiva desta apreensão imediata dos corpos do mundo circundante. Num domínio onde reinam as discrepâncias das percepções dos sujeitos porque as experiências são sempre variáveis, as coisas não podem conhecer nenhuma identidade no puro sentido da palavra, mas apenas uma suposta "identidade consigo mesma", que não passa de uma similitude "meramente aproximativa"70. Assim, na medida em que "esta gradação caracteriza-se como sendo de maior ou menor perfeição"71, mas sem poder tangenciar a perfeição absoluta, a coisa-em-si não será senão uma idéia situada no infinito, uma concepção inalcançável que permitirá a abertura do horizonte do irrefreável aperfeiçoamento das formas, na busca "da reta cada vez mais reta" e "do plano cada vez mais plano". Mas se este mundo parece se limitar à relatividade, como então a ciência poderia cumprir aquela sua aspiração à universalidade? Como as coisas deixam de apresentar uma determinação sempre subjetiva para serem enfim concebidas de modo objetivo? Aos olhos de Husserl, é somente com a geometria pura, conduzida sob a pena de Galileu, que a ciência consumará sua tarefa de ser "ciência da totalidade do mundo, da

\footnotetext{
${ }^{70}$ Idem, Krisis, §9a, p. 22.

${ }^{71}$ Idem, Ibidem.
} 
totalidade do ente"72. A geometria será a responsável por fornecer ao mundo uma determinação inequívoca, na qual as variações subjetivas das coisas cedem seu lugar à

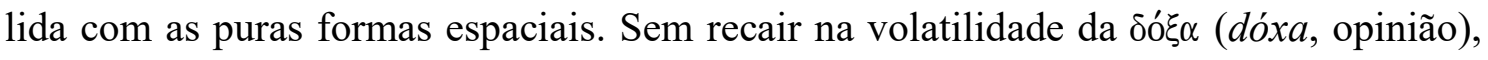
toda atenção estará depositada num "mundo de objetividades ideais infinito e fechado sobre si como campo de trabalho": geômetra algum, por princípio, se ocupará de meras aproximações, mas visará aquilo que "nos é negado na prática empírica: exatidão"73. E por exatidão não se compreenderá senão a possibilidade da forma ideal de gozar de uma identidade absoluta em sua determinação, em ser uma "verdade idêntica e irrelativa" "74: já não haverá mais "o que é reto para um, mas não é reto para outro" ou o fato de que "este é mais plano do que aquele"; para a geometria, haverá somente a certeza do idêntico, isto é, $a$ reta ou $o$ plano. Como ensinava Salviati ao ingênuo Simplício nos Diálogos de Galileu, o geômetra deve se portar como um mercador que, ao calcular "seus açúcares, sedas e lãs", desconsidera "a tara das caixas, embrulhos e outras embalagens"75, quer dizer, em sua atividade o geômetra deixará de considerar os corpos do mundo em suas imperfeições para apreendê-los por meio da abstração. E será esta abstração que os traduzirá para a única linguagem capaz de lhes conceder objetividade:

"A filosofia encontra-se escrita neste grande livro que continuamente se abre diante de nossos olhos (isto é, o universo), que não se pode compreender antes de entender a língua e conhecer os caracteres com os quais está escrito. Ele está escrito em língua matemática, os caracteres são triângulos, circunferências e outras figuras geométricas, sem cujos meios é impossível entender humanamente as palavras; sem eles nós vagamos perdidos dentro de um escuro labirinto"76.

Desde então, por obra de um único método, entendido como a dedução a partir de formas elementares ideais (axiomas), será permitido operar sobre qualquer figura do mundo com exatidão. Assim, é graças à geometria como Lehrmeisterin que as variações subjetivas cederão seu lugar às inequívocas verdades intersubjetivas. Eis então a tese forte desta nova física galileana, sua motivierende "Selbstverständlichkeit": a matematização da

\footnotetext{
${ }^{72}$ Idem, Ibidem, §8, p.19. Cf. Marcus Sacrini, Lições do mundo-da-vida: o último Husserl e o objetivismo; Ernildo Stein, Mundo vivido; Emmanuel Lévinas, A obra de Edmund Husserl; Emmanuel Lévinas, A ruína da representação.

${ }^{73}$ Idem, Ibidem, §9a, p. 23-24.

${ }^{74}$ Idem, Ibidem, 9b, p. 27.

${ }^{75}$ Galileu, Diálogos, p.289.

76 Idem, O Ensaísta, p. 38. Apud: Marcus Sacrini, Lições do mundo-da-vida: o último Husserl e o objetivismo, p. 357-364.
} 
natureza ultrapassa as modificações sempre presentes na apreensão do mundo circundante para encontrar, ao final, um único e mesmo mundo, uma realidade em si que não mais responde à relatividade quando interrogada acerca de seu modo de ser, mas que oferta uma "certeza vinculada a todos nós". Observado através das lentes da geometria, o mundo será antes de tudo objetivo num sentido muito próprio, "a saber, uma totalidade infinita de objetividades metodicamente e completamente ideais e determináveis de maneira inequívoca para todos"77.

Este objetivismo gestado em O Ensaísta e nos Diálogos (e nutrido pela geometria pura como método) não se restringirá, como é bem sabido, às páginas de Galileu. Ele conhecerá boa fortuna no curso da história da filosofia, encontrando sobretudo na obra de Descartes um terreno fértil no qual poderá espalhar suas raízes. E Husserl não deixará de notar este fato. Embora Étienne Gilson já tivesse ensinado que "o pensamento cartesiano estabelece, em relação às fontes medievais de que deriva, muito menos um progresso do que um empobrecimento" "78 (e as Meditações Cartesianas fizessem questão de mencionálo expressamente por isto), a Krisis insistirá que estes "restos de tradição escolástica" não eram os únicos pressupostos presentes no pensamento de Descartes e que as teses fundamentais do racionalismo ainda guardavam um "sentido profundamente velado" (ein tief verborgener Sinn $)^{79}$ sob a roupagem da aeterna veritas. Um sentido não tão velado quanto pretendia Husserl, é verdade, já que bastava ao bom leitor chegar à sinopse da segunda meditação para que o tivesse diante de si. Afinal, era ali o lugar onde se delineava o método para o desenvolvimento de uma "filosofia como "matemática universal"" 80 :

"De sorte que outra ordem não pude seguir senão a que empregam os geômetras, a saber, antecipando todas as coisas de que depende a proposição buscada antes de concluir algo a respeito dela" $"$.

\footnotetext{
${ }^{77}$ Edmund Husserl, Krisis, §9b, p.30.

${ }^{78}$ Étienne Gilson, O filósofo e a teologia, p.95. Cf. Étienne Gilson, La liberté chez Descartes e Études sur la rôle de la pensée médiévale dans la formation du système cartésien.

${ }^{79}$ Edmund Husserl, Krisis, §17, p.83.

${ }^{80}$ Idem, Ibidem, $§ 16$, p. 81. Esta leitura da filosofia cartesiana como uma "matemática universal", tal como Husserl a realiza, é questionada pela interpretação que Jean-Luc Marion oferta às Regulae: "Assim, o que está em jogo na Regra II, reside menos no estabelecimento do paradigma matemático para todo saber do que na meditação da certeza como única modalidade epistemológica aceitável, seja qual for o objeto a que ela se aplique (...) Não se trata de matematismo, dado que as próprias matemáticas se compreendem a partir do desdobramento do método". Jean-Luc Marion, Sobre a ontologia cinzenta de Descartes, $\S 4$ e $\S 9$, p. 49 e 83 .

81 "Ideoque non alium ordinem sequi potuisse, quam illum qui est apud Geometras usitatus, ut nempe omnia praemitterem ex quibus quaesita propositio dependet, antequam de ipsa quidquam concluderem". René Descartes, Meditationes, Med. II, Synopsis, §1, p 36. Husserl dizia claramente em suas Meditações
} 
Se então o padrão da certeza exigido - já se dizia desde as Regulae - era aquele das demonstrações aritméticas e geométricas, nada mais natural que o procedimento seguro para bem conduzir a razão fosse aquele vigente entre os geômetras. E quanto à natureza deste $\operatorname{ordo}$, não parecia haver qualquer segredo para aqueles que já haviam freqüentado os Elementa de Euclides: a reflexão consistia no encontro de certum purum et simplex (e nunca compositum et respectivum) que viesse a se comportar como um fundamentum donde se deduziriam todas as proposições posteriores. Tratava-se assim de um método a ser conservado duma ponta à outra das Meditationes, e para o qual nenhuma linha sequer constituía exceção. Mesmo a suposta ignávia cartesiana no momento da análise do conceito de animal rationale não passava de uma burla: se Descartes recusava a célebre definição aristotélica como ponto de partida, não era porque “o tempo de que disponho já não é tanto para que o queira malbaratar em sutilezas desta ordem" (nec iam mihi tantum otii est, ut illo velim inter istiusmodi subtilitates abuti $)^{82}$, mas sim por entender que ela se esquivava aos parâmetros do mos geometricus; já não havia sentindo em recorrer a um consagrado "composto" quando a exigência primeva apontava para a necessidade de

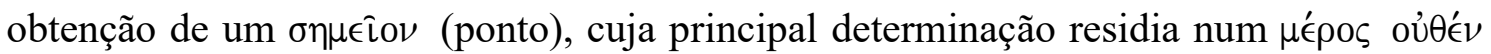
(não possuir nenhuma parte) ${ }^{83}$. E o que não viria a ser o encontro com a mens sive animus sive intellectus senão a conquista do almejado elemento puro e simples, do ponto arquimediano, a partir do qual tudo se move? O ego figurava assim como o responsável por colocar em curso todo processo de deductio, por atuar como um guia a toda passada dada pelas meditações subseqüentes à obtenção de sua certeza primordial. Era este ego, portanto, no desdobramento de sua pureza e simplicidade, que permitia Descartes discernir a existência de substantiae diversae (substâncias diversas) e a se mutuo distinctae (mutuamente distintas uma da outra) ${ }^{84}$, quer dizer, era por meio das deduções que tomavam este ego como "ponto" que o mundo via justificada sua existência. Por isso, no momento em que se dava a reconhecer que, ao lado do ego, o mundo era também uma região de ser ontologicamente independente, Descartes assumia sem reservas a tese galileana de "um mundo de corpos realmente separado e fechado sobre si" ${ }^{\circ 5}$, fazendo de seu pensamento "o cartório filosófico no qual se legitimavam os títulos de crédito da nova

Cartesianas: "O próprio Descartes possuía antecipadamente um ideal de ciência: aquele de geometria ou da ciência matemática da natureza”. Edmund Husserl, Cartesianische Meditationen, §3, p. 9.

${ }^{82}$ Idem, Ibidem, Med. II, §6, p. 44.

${ }^{83}$ Euclides, Elementa, pars prima, B. G. Teubneri, 1883-1885 (reeditado por Richard Fitzpatrick, 2008), p.6.

${ }^{84}$ René Descartes, Meditationes, Med. II, Synopsis, p. 36.

${ }^{85}$ Edmund Husserl, Krisis, §10, p. 61-62. 
ciência da natureza" ${ }^{\prime 86}$. Pois, ao abandonar o seu preceito de exclusão de pressupostos, as Meditationes deixavam escorrer por entre os dedos o ineditismo que a esfera do ego permitia entrever justamente porque a consideravam como um simples meio para a consumação de um objetivo (Ziel) sempre pressuposto: levar a termo aquela proposta de Galileu de poder realizar "um conhecimento universal e absolutamente fundado de um mundo pensado como um transcendente 'em-si" " ${ }^{87}$. Desde então, dirá Husserl, é este mesmo conceito de mundo, resultante dos esforços de Galileu e corroborado pela "pressa de Descartes", que a filosofia não cessará de repetir (chegando até mesmo às Investigações Lógicas) e que a psicologia reconhecerá como condição de possibilidade do conhecimento devido à sua incontestável presença para o sujeito encontrado no mundo e em relação para com ele.

\section{V - A orientação fenomenológica}

Mas se a existência deste mundo em si parecia tão bem assegurada, a ponto de fazer da anunciada "ruptura" das Investigações Lógicas um eco da tradição, o que restava à fenomenologia? Ela estaria fadada a permanecer à sombra de Descartes e sua eversio não passaria de um vazio de sentido? Muito pelo contrário. Diante desta dificultosa e comprometedora predominância do mundo, a fenomenologia se verá renovada em sua eversio e se estabelecerá num território que, agora sim, lhe será próprio. E o primeiro esboço desta tarefa estará situado nas preleções de $A$ idéia da fenomenologia, em cujas páginas Husserl traçava as linhas gerais da dita fenomenologia transcendental ao colocar em questão a tese fundamental da atitude natural. O que ali se indagava era justamente se o mundo, tal como apresentado pela filosofia e pela psicologia, sustentava-se como condição de possibilidade de todo conhecimento. E muito distante da concordância conservada nas Investigações Lógicas, o teor da resposta obtida não era em nada ameno: se o mundo podia desfrutar daquele predicado de "inquestionável” graças ao ordo que encerrava-o em si, isto somente ocorria porque a forma da pergunta que permitia sua determinação enquanto sentido mais favorecia descaminhos do que prezava pela boa razão. A tradição não fazia senão interrogar se o conhecimento do mundo era possível. Ora, uma questão formulada neste molde não afetava em nada a maneira segundo a qual

\footnotetext{
${ }^{86}$ Carlos Alberto Ribeiro de Moura, Cartesianismo e Fenomenologia, in: Racionalidade e Crise, p. 211

${ }^{87}$ Edmund Husserl, Krisis, §21, p. 85-86.
} 
a orientação natural concebia a condição de possibilidade de seu conhecimento. Afinal, "nenhum homem razoável duvidará da existência do mundo" 88 , pois é indubitável o fato de que $(d a \beta)$ esta transcendência do mundo é sempre dada aí e que, por isto, ela é assumida como o sentido de todo saber. Enquanto esta transcendência selbstverständlich estiver assegurada ao sujeito, a possibilidade de conhecimento objetivo não sucumbirá a nenhuma espécie de "desespero cético" (skeptische Verzweiflung). Mas era esta a questão a ser respondida? Certamente não - a ponto de levar Husserl a escrever que uma "teoria do conhecimento" principiada pela indagação "se..." e não como (wie) o conhecimento é possível, talvez nem seja digna do nome que carrega, pois, antes de ser teoria, ela é apenas prova de ingenuidade, "uma tolice patente" 89 . Afinal, quando os partícipes da orientação natural afrontavam a questão de "como" poderiam conhecer, só podiam responder que conheciam porque o objeto de seu conhecimento sempre lhes fora dado como um ai, um selbstverständlich. Isto faz com que esta suposta "teoria do conhecimento" esteja alicerçada numa tautologia e seja, no fundo, impraticável: sem conhecer o como e reafirmando ininterruptamente o que, ela não faz senão enclausurar-se no absurdo de propor que o possibilitado $(d a \beta)$ atua como possibilidade (wie). "A possibilidade mesma vigora como um transcendente, como uma possibilidade sabida, mas não dada ou intuída" ${ }^{90}$. É por isto, dirá Husserl, que todo aquele que se encontra imerso na orientação natural é como um surdo exposto a uma sinfonia: muito embora o mouco saiba que ali tons estão presentes, fundamentando toda a peça, é impossível que saiba como eles a compõem.

Se então é verdade que o mundo em si - enquanto condição de possibilidade do conhecimento - tornava-se insustentável por não passar de mais uma parvoíce dogmática, aquilo ao qual ele conferia sentido também deixava de desfrutar das prerrogativas que dele provinham. Uma vez que a independência ontológica do mundo não mais se justifica em sua falácia, o tradicional "dualismo" será entendido como mera fabulação. Por isso, antes de ser a forma pela qual o conhecimento se apresenta, a "representação" será somente o fruto de um extravio cuja "certeza objetiva do conhecimento em geral tornase, segundo seu sentido e possibilidade, enigmática e também dubitável, e os conhecimentos exatos não se fazem menos enigmáticos dos que os não-exatos, do mesmo modo que conhecimentos científicos não se fazem menos enigmáticos do que não

\footnotetext{
${ }^{88}$ Idem, Die Idee der Phänomenologie, p. 36.

${ }^{89}$ Idem, Ibidem, p. 37.

${ }^{90}$ Idem, Ibidem.
} 


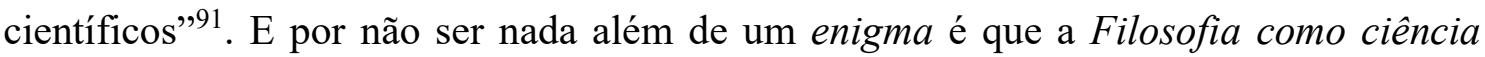
rigorosa não cessará de acusar os saberes regidos pela orientação natural de jamais cumprirem a promessa de cientificidade da filosofia; fundamentada por um "sentido" que se provou, na verdade, uma estátua com pés de barro, a filosofia siderada pela orientação natural nunca foi estritamente filosófica: filha de uma "ingenuidade imortal", comum a cada momento da história do pensamento, ela sequer uma vez chegou a tratar "o sentido próprio dos problemas filosóficos" de maneira rigorosamente científica ${ }^{92}$. Quando Kant então professava que "não se pode ensinar filosofia, mas apenas a filosofar", a proposição apenas atestava - aos olhos de Husserl - a falência da filosofia em sua tarefa, afinal ela não podia ser ensinada porque ainda não havia sido consumada como ciência, carecendo de conceitos, problemas e métodos claramente definidos. Por sempre ter se comportado como um "pensamento natural", a filosofia apartou-se do rigor que ela mesma estabeleceu como tarefa, e no lugar de cientificidade o que ela obteve foi apenas a determinação vazia do conhecimento como die allerselbstverständlichste Sache, como um mistério (Mysterium) resultante da privação de sentido $^{93}$. Um mistério - indica Husserl em momento de rara delicadeza em sua retórica ríspida - no sentido grego do termo, isto é, como fruto ( priva da possibilidade da visada nítida do verdadeiro sentido por conceder ao mundo uma honraria da qual ele nunca foi merecedor. E na medida em que este mistério surgia como a mácula que conduzia às profundezas "onde jaz a escuridão e na escuridão jazem os problemas", não era de se estranhar que a eversio da fenomenologia transcendental, em sua indagação por um wie autêntico, fazia sua aparição na cena filosófica com uma exigência que recuperava toda significação de sua etimologia ( $\varphi$ aıvó $\mu \varepsilon v o v$, “fenômeno"): "o que eu quero - dirá Husserl - é clareza"94. Mas o que era agora esta clareza pretendida pela fenomenologia transcendental? Se há razão nas palavras de Lévinas ao afirmar que "abordar a consciência enquanto realidade é fechar os olhos à dimensão específica do sentido"95, pode-se muito bem entender este processo de clarificação como um "abrir os olhos" para uma nova compreensão da consciência que não a envolva por um casulo real. No afastamento deste vulto temeroso da realidade, a clareza surge como um novo método

\footnotetext{
${ }^{91}$ Idem, Ibidem, p. 24-25.

${ }^{92}$ Idem, Philosophie als strenge Wissenschaft, $\S 2$ e $\$ 23$, p. 8 e 19.

${ }^{93}$ Idem, Die Idee der Phänomenologie, p. 19.

94 Idem, Ibidem, p. 6-10. Cf. também Edmund Husserl, Ideen I, §68. Cf. Pierre Chantraine, Dictionnaire étymologique de la langue grecque. Histoire des mots, p. 728.

${ }^{95}$ Emmanuel Lévinas, A obra de Edmund Husserl, in: Descobrindo a existência com Husserl e Heidegger, p. 41.
} 
e uma nova orientação em face daquela natural; é a clareza enquanto "orientação fenomenológica" que permitirá o cumprimento da promessa de uma ciência rigorosa, naquilo que a "filosofia quer e deve fazer", a partir do encontro com uma consciência purificada e enfim merecedora da alcunha de "sentido".

Assim, já no limiar da fenomenologia transcendental pode-se falar que a clareza é indicativo de um caminho de pensamento (Gedankengang). Não um caminho qualquer, é verdade, mas um muito específico, cujo curso será de reafirmação da herança da eversio. Se desde as primeiras linhas de A idéia da fenomenologia Husserl fazia questão de apontar o caráter enigmático do conhecimento em geral, era para que se compreendesse a necessidade da crítica do conhecimento em principiar pela negação absoluta. Uma vez que todo saber de origem "natural" tornava-se nocivo por pressupor um injustificado "mundo em si", a crítica fenomenológica renovava, por isso mesmo, a exigência de que tudo fosse "colocado em questão" (in Frage stellen). Os primeiros passos da receita das Meditationes eram então fielmente seguidos e podia-se com isso acompanhar a confissão daquela influência exercida desde as Investigações Lógicas: "a consideração cartesiana da dúvida oferece-nos um começo" "96. Era quase possível ouvir ali o deceptor, o gênio maligno de Descartes, clamar por uma dúvida hiperbólica. Não que Husserl recorresse ao subterfúgio de uma divindade às avessas para obter a evidência do fundamento. Longe disso. Este eco de um deceptor não era nenhuma reminiscência do argumento de um ladino de ordem divina, mas sim a inescapável influência da negação absoluta como origem. Sem gênio maligno, mas ainda com a imposição de um índice de nulidade: "todo transcendente (aquilo que não me é dado de modo imanente) deve ser tomado por um índice de nulidade" ${ }^{97}$. E, assim como nas Meditationes, o ponto onde deságua o dubitare é bastante conhecido: por mais que se insista em proferir um juízo absolutamente negativo, colocando em questão a totalidade das coisas e seus saberes, ainda é impossível que a dúvida universal negue a si mesma; em consonância com Descartes, será reconhecido que "em todo caso de um duvidar determinado, é certamente indubitável que assim duvide"98. Mesmo que todo conhecimento se torne questionável porque enigmático e carente de fundamento, o ato de duvidar resta intacto em sua certeza. Mais do que isto: não apenas esta vivência da dúvida pode doar-se diretamente à apreensão, mas "toda vivência intelectiva e toda vivência em geral, enquanto consumada, pode fazer-se objeto

\footnotetext{
${ }^{96}$ Idem, Die Idee der Phänomenologie, p. 4.

97 Idem, Ibidem, p. 6.

98 Idem, Ibidem, p. 30.
} 
de um puro intuir e apreender, e neste intuir ser uma doação absoluta"99. Será a partir desta apreensão das vivências - que Husserl batizará de "pura" - que a fenomenologia transcendental irá se apresentar como uma teoria do conhecimento enraizada num solo absoluto e indubitável, na contrapartida do enigma da orientação natural. Mas o que haveria de original e propriamente fenomenológico nessas passagens que mais parecem uma transcrição das Meditationes em terminologia contemporânea? Aqui, dirá Husserl, a semelhança no encontro com as vivências é meramente aparente, pois, para que venha a ser o absoluto, "a cogitatio cartesiana carece, a princípio, da redução fenomenológica"100. Ora, que a cogitatio cartesiana deva ser reduzida, significa que o modo pelo qual ela se faz presente no terreno da teoria do conhecimento deve ser purgado de toda peçonha do real. E antes de marcar alguma privação, ela será a responsável pela expansão da subjetividade na base de uma auto-doação absoluta. Portanto, reduzir a cogitatio cartesiana é negar-lhe o passo comprometedor, evitando o desdobramento dedutivo que lhe permitia o avanço em direção a uma esfera ontológica sem sentido próprio. O que a redução coloca à parte das considerações é exatamente o ser em si do mundo e, com ele, o homem enquanto local privilegiado do imiscuir de substâncias: se para Descartes era lícito interrogar acerca da evidência sensível do próprio sujeito (“...ut me iam hic esse...") ${ }^{101}$, para doravante concluir que a mens sive animus sive intellectus não estava dissociada de sua condição intra-mundana, para Husserl a consciência absoluta não era nenhum ente (esse), identificado ao ego psicofísico (me), na duração do tempo objetivo (iam) e ocupando um determinado espaço (hic). E se é assim, a fenomenologia transcendental entenderá a "medida última de todas as coisas" como aquela doação das vivências para si mesma (Selbstgegebenheit) em sua clareza sem par ("das in sich ist, was es ist...”), ao ser colocada "'como que' diante dos olhos" (“' 'gleichsam'vor Augen stehen...”) por obra de uma inigualável intuição. Somente em razão desta visada límpida é que Husserl poderá engendrar uma ciência rigorosa do conhecimento em geral, não mais o tratando como um Faktum natural, mas acolhendo-o em sua essência - quer dizer, "fazendo-o claro, trazendo-o à luz"102. É então com a redução da cogitatio cartesiana que a fenomenologia transcendental deixará "definitivamente o solo da psicologia, mesmo

\footnotetext{
${ }^{99}$ Idem, Ibidem, p. 31.

${ }^{100}$ Idem, Ibidem, p. 7.

101 “...que eu já estou aqui...”. René Descartes, Meditationes, Med. I, p. 24. “Desde logo, o meu pensamento de ser humano constituído já não é puro ato de emprestar um sentido, mas uma operação efetuada sobre o mundo e no mundo, um trato com o real". Emmanuel Lévinas, A obra de Edmund Husserl, in: Descobrindo a existência com Husserl e Heidegger, p. 46.

102 Edmund Husserl, Die Idee der Phänomenologie, p. 32.
} 
aquela descritiva", para se centrar no único sentido verdadeiramente autêntico de todo ser, o Erkenntnisphänomen (fenômeno do conhecimento) ${ }^{103}$.

Contudo, algum órfão de Descartes poderia interpelar em favor de sua origem e levantar o seguinte problema: não obstante Husserl fizesse uso do subterfúgio da redução para desvencilhar sua cogitatio daquela das Meditationes, a eversio em seu momento inicial permanecia fundamentalmente a mesma, quer dizer, "o cartesianismo de Husserl se igualava inevitavelmente a uma retomada e uma reelaboração do problema cético"104, servindo-se ainda da negação absoluta para a dita apreensão "convenientemente modificada" 105 das vivências. E este argumento tinha sua aparente razão de ser não apenas no primeiro esboço da fenomenologia transcendental de $A$ idéia da fenomenologia (em sua remissão à "consideração cartesiana da dúvida"), mas parecia surgir com força redobrada nas teses de Idéias I. Afinal, poderá dizer o cartesiano orgulhoso, era ali que a fenomenologia, "indissociável da séria consideração do ceticismo"106, evocava as obras de Hume, de Kant e sobretudo de Descartes para definir-se, "por assim dizer, como o anseio secreto (geheime Sehnsucht) de toda filosofia moderna" ${ }^{\text {107 }}$. Mas se é assim, de que importava aquela purificação da cogitatio pela redução se o assecla de Descartes tinha razão em considerar a fenomenologia ainda um resquício da motivação original das Meditationes, dado seu início por meio de uma "disposição fundamental do ceticismo" (Grundstimmung der Skepsis)? A eversio husserliana, que parecia tão bem funcionar em relação ao mundo em si, falhava ali, no momento dilucular do método, por ser indissociável da negação? Soava, sem dúvida, como uma condenação auto-imposta o fato de que uma ciência de pretensões rigorosas, regida pelo preceito da ausência de pressupostos, cultivasse uma inclinação cética, de sabor cartesiano. Todavia, esta leitura não passava de um falso alarde ou uma imputação caluniosa que Husserl afastaria da redação definitiva de sua fenomenologia transcendental. Se é verdade que a "consideração cartesiana da dúvida" era um momento fundamental da argumentação de A idéia da fenomenologia, ela não contará com o mesmo posto de lisonja em Idéias I. Aqui, antes que o "anseio secreto" fosse o eco de uma obra noutra, ele surgia para rememorar que "a experiência universal da dúvida deve servir somente como auxílio

\footnotetext{
${ }^{103}$ Idem, Ibidem, p. 7.

${ }^{104}$ Claude Romano, La phénoménologie doit-elle demeurer cartésienne?, p. 28.

105 "Descartes empregou essa consideração para outros fins; modificada de modo conveniente, podemos utilizá-la aqui". Edmund Husserl, Die Idee der Phänomenologie, p. 30.

${ }^{106}$ Claude Romano, La phénoménologie doit-elle demeurer cartésienne?, p. 31.

${ }^{107}$ Edmund Husserl, Ideen I, §62, p. 133 e $\$ 63$, p. 136.
} 
metódico" ${ }^{108}$. Somente um auxílio metódico, nada além disso: para a fenomenologia transcendental delineada neste momento, a via negativa deixava de ser uma possibilidade de início, uma vez que a eversio ali atuante reivindicava um grau de pureza ainda maior, quer dizer, embora o movimento hiperbólico servisse de inspiração, a eversio da orientação fenomenológica já não via a necessidade de operar sobre o mesmo terreno de Descartes e recorrer à negação como princípio. Quando o filósofo desencadeia a dúvida ininterrupta e conserva o juízo da negação absoluta de todo ente, Husserl entende que ele ainda não é capaz de alterar sua orientação de pensamento somente por obra deste expediente. Na verdade, aos olhos do bom fenomenólogo, aquela inabalável convicção cética, herdada da filosofia moderna, era ilusória: o ceticismo que impulsionava a reflexão cartesiana afastava-se da orientação natural apenas de maneira superficial; embora os juízos acerca do mundo estivessem fora de consideração, isto se dava graças a um juízo também ele mundano e naturalmente orientado, que, ao invés de corroborar a tese da existência do ser das coisas, anunciava sua antítese “com a 'junção' do não-ser, que forma a base comum da dúvida"109. Tentar excluir todo juízo de orientação natural empregando um juízo negativo da mesma ordem - eis aí o contra-senso que fazia do duvidar hiperbólico uma mera negação universal e não uma guinada de orientação. Já a verdadeira

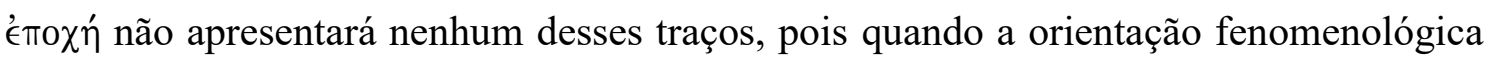
entra em cena da maneira devida, dirá Husserl, “eu então já não nego este 'mundo' como se eu fosse um sofista e já não duvido de sua existência como se fosse um cético" ${ }^{110}$. E se é assim, o procedimento metódico de Idéias I não será um eivado "colocar em questão" (in Frage stellen) à maneira dos céticos, mas sim um "colocar entre parênteses" (einklammern), para o qual a presença de nenhum juízo positivo ou negativo se faz necessária. Ora, quando bem compreendida, aquela "experiência universal da dúvida", responsável por nutrir as esperanças dos que insistiam em ver ali algum indício de uma doutrina não emancipada da negação absoluta, nada tinha de efetivamente dubitante uma vez que em sua determinação de base a dúvida (e com ela a totalidade dos saberes) apartava-se da fundação de uma teria do conhecimento. Longe de consistir num flerte com a primeira meditação, aquele "auxílio metódico" estava ali colocado para demonstrar como também a dúvida trazia marcas de impureza e que, por esta razão, permanecia profundamente arraigada na orientação natural. A є̇тохท́ fenomenológica

\footnotetext{
${ }^{108}$ Idem, Ibidem, §31, p. 62.

${ }^{109}$ Idem, Ibidem, \$32, p. 63-64.

${ }^{110}$ Idem, Ibidem, §32, p.65.
} 
será, portanto, radicalíssima: não há nada que não esteja "entre parênteses", fora do circuito de consideração propriamente filosófica; ela lá está como a proteção metódica necessária à exigência do rigor, para nos livrar de tudo que se enraíza no espírito sem razão e que parece tentar nossa natureza de "dogmáticos natos"111. Então, ensinará Husserl, a fenomenologia transcendental de Idéias I será, agora sim, o verdadeiro cumprimento de uma eversio no superlativo, pois "a partir daí ela exige a perfeitíssima (vollkommenste) exclusão de pressupostos e a evidência reflexiva absoluta em relação a si mesma. Sua própria essência está em realizar a perfeitíssima (vollkommenste) clareza sobre sua própria essência e também sobre os princípios de seu método" $" 112$.

\section{VI - A consciência transcendental}

Mas um respeito tão ferrenho à noção de eversio e uma purgação tão violenta das Meditationes - uma verdadeira evisceração de Descartes com os instrumentos que ele mesmo fornecia - naturalmente conduzia Husserl à agudeza de outros heróis do discurso da pureza que pudessem guiá-lo na fundação desta consciência transcendental. Poder-seía certamente pensar em Hume, afinal o Tratado era confessamente reconhecido como "o primeiro esboço de uma fenomenologia pura, embora sob a forma de uma fenomenologia puramente sensualista e empírica"113. Seria, sem dúvida, um bom começo, mas demasiadamente modesto por se tratar apenas de um "primeiro esboço". Talvez Kant e sua revolução copernicana... Uma suspeita razoável, mas também ela pouco profícua, uma vez que a exposição de Filosofia Primeira já afastava esta possibilidade "em virtude da ausência de tomadas de consciência últimas", impedindo Kant de "elaborar o gênero e o método de uma análise da consciência" por maior que "tenha sido o ardor na entrega às investigações sistemáticas" 114 . Mas se nem de Hume, nem de Kant, de qual fonte então bebia Husserl para dar a justa forma de sua fenomenologia transcendental? Sobre esta inspiração nada óbvia, uma passagem ainda pouco referida da Krisis parece dar boa pista sobre a resposta:

\footnotetext{
${ }^{111}$ Idem, Ibidem, $\$ 31$, p. 62 e $\S 61$, p. 130-132.

112 Idem, Ibidem, $\$ 63$, p. 136.

${ }^{113}$ Idem, Erste Philosophie, I, p. 157. Cf. Gérard Lebrun, David Hume no álbum de família de Husserl, in: A filosofia e sua história, p. 258.

${ }^{114}$ Idem, Ibidem, I, p. 237.
} 
"Mostrar-se-á até mesmo que a orientação fenomenológica total e a Epoché que lhe pertence são evocadas para que se obtenha uma completa modificação pessoal -a qual seria necessária comparar primeiramente a uma conversão religiosa (mit einer religiösen Umkehrung), que a partir dai contém em si a significação da maior modificação existencial que é dada à humanidade enquanto humanidade"115.

Uma conversão religiosa? Que espécie de conceito de conversão seria este com o qual a orientação fenomenológica se comparava de maneira tão inesperada? Ora, ciente de que este simples apontamento poderia privar seu leitor da sempre exigida clareza, abandonando-o diante de mais de um milênio de filosofia medieval cristã, Husserl deixará noutra parte uma indicação pouco mais precisa: a fenomenologia, na verdade, não apenas "lembrava de fato o discurso dos místicos""116, mas chegava ao ponto de poder, nesta semelhança, "recuperar páginas inteiras de Meister Eckhart, sem modificações"117. Inspiração bastante excêntrica: era então nos Sermões místicos eckhartianos que Husserl buscava a técnica para urdir este nobre tecido da fenomenologia transcendental.

Que a disciplina husserliana se encontre com o pensamento místico significa, como já se pretendeu, que ela esteja fundada "em práticas emocionais que dela façam,

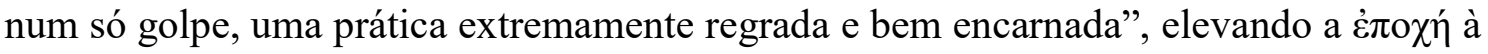
condição de "prática da prece do coração"? Quer dizer, numa espécie de "redução avant la lettre", os místicos já ensinavam a "de fato praticar a redução" por meio de "uma encarnação deveras exemplar”? ${ }^{118}$ E seria este procedimento já encontrado na mística o responsável por nos permitir "pensar a fenomenologia de forma revigorada" e "nos colocar em uma nova marcha existencial"? ${ }^{119}$ Nada poderia estar mais distante da letra do texto de Husserl. Afinal, caso a fenomenologia transcendental assumisse a possibilidade de uma redução enquanto prática encarnada (intra-mundana, portanto) e

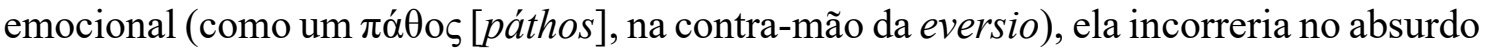
de negar a si mesma já na porta de entrada desta nova orientação do pensamento. A crítica parece ter confundido inventividade no trato com a história da filosofia com anacronismo grosseiro ao defender a tese perturbadora de que, no coração da mística medieval, a visada

\footnotetext{
115 Idem, Krisis, §35, p. 140.

${ }^{116}$ Idem, Die Idee der Phänomenologie, p. 62.

${ }^{117}$ Dorion Cairns, Conversations with Husserl and Fink, "conversation with Husserl, 27/6/1932", p. 91.

${ }^{118}$ Natalie Depraz, Pratiquer la réduction: la prière du coeur, p. 504. Cf. também Natalie Depraz, Edmund Husserl, Adversus haereses mystikes, p. 327-347

119 Yves Meessen, Percée de l'ego: Maître Eckhart en phénoménologie, tese de doutorado, Universidade de Poitiers, 2014, p. 21. Cf. sobretudo $\S \S 1-2, \S 4$ e $\S 30$.
} 
fenomenológica era já praticada com muita desenvoltura. Neste sentido, os intérpretes falham pura e simplesmente porque torturam as obras, extorquindo-lhes confissões que estão mais alinhadas aos seus devaneios do que propriamente às palavras dos filósofos. Mas mediante este extravio da análise da relação entre mística e fenomenologia, a pergunta ainda resta sem resposta: quem é, afinal, o Meister Eckhart ao gosto de Husserl? Quais eram aquelas famigeradas páginas que deveriam ser conhecidas pelos fenomenólogos? Ora, encontrá-las não exigirá um longo arar dos Sermões. Era ali, na primeira pregação do Mestre, que se compreendia o advento da inspiração da orientação fenomenológica enquanto visada não mais natural. Tudo tem início com o comentário de

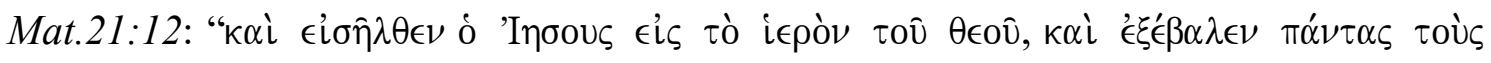

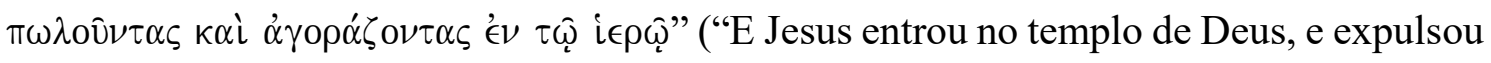
todos os que vendiam e compravam no templo"). O episódio da expulsão adquire um significado profundo sob a pena de Eckhart: aqueles que se põem a comercializar em nome do divino são a representação de seu desconhecimento e das próprias trevas; compradores e vendedores, em sua preocupação de submeter o eterno aos interesses seculares, conspurcam um templo que é local de luz e verdade enquanto morada do divino. "Luz e trevas não podem coexistir. Deus é a verdade e a luz em si mesmo (Got der ist diu wârheit und ein lieht in im selber)" ${ }^{\prime 20}$. Assim, o templo tomado por mercantes não passa de um antro obscurecido, próprio das tenebras (vinsternisse), e cuja ausência do sentido faz com que todos aqueles que o acolham nessa forma velem a verdade e residam na insipiência. Na medida em que o secular, representado pela mercancia em local sacro, consiste no obscurecimento do sentido, a expulsão não será senão o seu contrário, isto é, a abertura do sentido ou clareza da revelação: "quando Deus vem a este templo, ele expulsa a insipiência, que são as trevas, e revela a si mesmo com luz e verdade (...und offenbâret sich selber mit liehte und mit wârheit)" ${ }^{" 121}$. Purga-se o local da verdade, revelando-a na presença da luz. E um templo vazio das coisas do mundo, dirá Eckhart, é tal como a alma que não conserva recônditos ou opulência, mas apenas $o$ vazio e $a$ pobreza. Não uma inclinação à pobreza externa e material, mas àquela já professada pelo

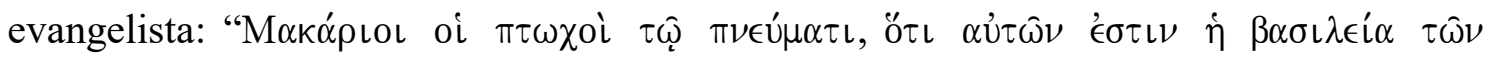
oủ $\alpha \nu \omega \hat{\omega}$ " ("Bem-aventurados os pobres de espírito, porque deles é o reino dos céus", Mat.5:3). Quer dizer, uma pobreza que, restringindo-se ao espírito, liberta de toda

\footnotetext{
${ }^{120}$ Meister Eckhart, Predigten, Predigt I, p. 12.

${ }^{121}$ Idem, Ibidem.
} 
cognição de teor mundano e faz com que este "homem pobre" conheça a absolvição do telúrico. Quando pobre (pauper), o homem é absolutus - um apartado ou sem as amarras seculares, que "nada conhece, nada sabe e também nada crê" 122 . Se então o mundo nada oferta quando se busca pelo sentido, aquele que "perde" o mundo na pobreza do espírito na verdade não perde coisa alguma, pois "abandonando a si mesmo e todas as coisas"123, desvela um domínio mais puro e fundamental que o mundo. A alma do homem que abandona está longe de ser um território de barganhas, aberto aos "compradores e vendedores": ao homem absolutus resta somente a pureza, tal como ouvida na fala de Jesus num templo já vazio - uma fala que de tão singular não mais diz o que é, mas como $e ́$, porque resultado de uma contemplação (Anschauung) de Deus e não de uma apreensão inteligível que se esgota ${ }^{124}$.

Parecem ter sido estas páginas dos Sermões que exerceram fascínio sobre Husserl e o inspiraram na composição da fenomenologia transcendental. E sobre esse "batismo" filosófico levado a termo pelo pensamento místico, as linhas de Idéias I dão bom testemunho. Afinal, era ali que Husserl, ao convidar seu benevolente leitor à investigação fenomenológica, introduzia-o a uma inusitada reflexão sobre o vazio. Para ele, o início da teoria do conhecimento encontrava-se com o conceito do "homem pobre" das pregações: o filósofo que indaga sobre o sentido não pode ser senão absolutus e, em sua absolvição, não deve se servir de qualquer saber oriundo do mundo enquanto premissa. Esta promessa de "pobreza", exigida pela exclusão de pressupostos, cumpria-se no momento em que a

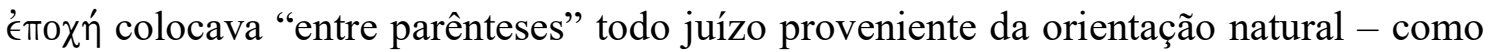
uma espécie de Jesus que afastava o mundano e esvaziava o templo - com o intuito de apreender em si mesmas as vivências reduzidas, sem nenhum resquício real e "na essência do vazio e da própria vagueza" de seus modos de doação. Somente com a apreensão

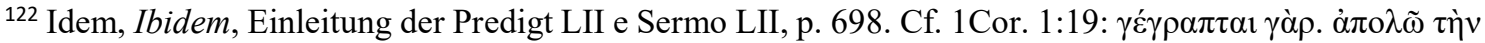

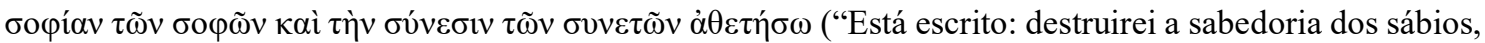
e aniquilarei a inteligência dos inteligentes"). Esta absolvição eckhartiana ecoará o sermão paulino de 1 Cor.

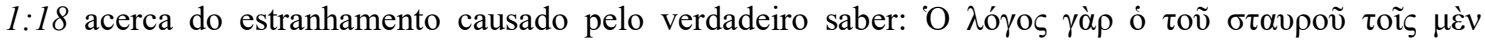

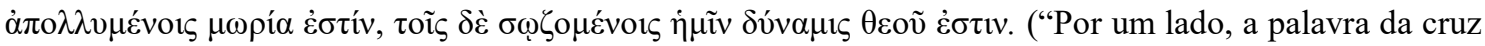
é loucura para os que perecem; por outro lado, para nós que somos salvos, é o poder de Deus").

${ }^{123}$ Idem, Ibidem, Predigt XXVIII, p. 318. Aqui, para acentuar este afastamento do mundo, Meister Eckhart utilizará uma versão distinta de João 15:16. Enquanto os textos grego e latino dizem "vós não me

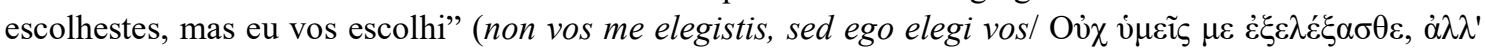

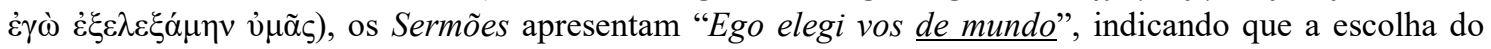
discípulo pelo mestre é uma extração do mundano.
}

${ }^{124}$ Idem, Ibidem, Predigt I, p. 19. 
essencial das vivências "esvaziadas", dirá Husserl, será possível entender que este vazio "não é, por sua vez, vazio", mas sim "a mais completa e perfeita clareza" do sentido, que dissipa toda especulação enigmática e todo teor obnublado do conhecimento com "um círculo de luz do puro dado" (Lichtkreis des Reingegebenen) ${ }^{125}$ das vivências para as próprias vivências. Por isso, tal como se dava com a mística medieval, a "perda do mundo" não será nenhuma limitação (Einschränkung) no sentido habitual da palavra, mas deverá ser entendida como uma redução (Beschränkung) à única esfera de sentido verdadeiramente possível. A iluminação do sentido ocorrerá, portanto, quando a consciência, esvaziada do real, obtiver uma pura doação de si mesma e, nesta doação, já não apreender o que é, mas sim como tudo aquilo que é, veio a ser; "não estando nem no mundo, nem fora dele", dirá Husserl conforme uma fórmula eckhartiana do Sermão XXVIII, a consciência em sua pureza e clareza será lux in luce et in lucem se toto se totum penetrans ("luz que se penetra toda inteira") ${ }^{126}$. E como se sabe, esta clareza da consciência transcendental só poderá ser promulgada pela fenomenologia por obra de um método que não se equiparava ao ordo geometricus. Uma vez que a glória da eversio significava a ruína do método cartesiano, fazendo de "toda imitação do procedimento matemático não somente infrutífera, mas invertida e de conseqüências extremamente prejudiciais" ${ }^{127}$, Husserl não apenas concederia à intuição o direito de cidadania em sua filosofia, mas também a condecoraria com o título insigne de "princípio de todos os princípios". Tratava-se de uma intuição sem compreensão (intuitio sine comprehensione), cuja universalidade de forte teor místico impedia qualquer desdobramento dedutivo e teórico. E se era assim, quando ali se falava em intuição, não se podia estar mais distante do traçado que outrora a Crítica da Razão Pura pretendeu lhe conferir: longe de permanecer no claustro da sensibilidade, a intuição era a visada amplíssima e direta da qual nada escapava e para a qual nada constituía uma exceção. Tudo perpassando, sem que região alguma fosse para ela inacessível, a intuição fenomenológica já não se portava como mera Anschaulichung, mas como uma Veranschaulichung capaz de aprender o sentido "como puro dado em si, inteiramente, como ele é em si mesmo"128. Era então esta

\footnotetext{
${ }^{125}$ Edmund Husserl, Ideen I, §67, p. 141-142.

${ }^{126}$ Idem, Manuscrito AVI 21, p. 25a (Ct. Claude Romano, op. cit., p. 37). Meister Eckhart escreve no Sermão XXVIII: "Ela [a pureza] não está nem no mundo, nem fora dele...", p. 322.

${ }^{127}$ Idem, Ideen I, Einleitung, p.6.

${ }^{128}$ Idem, Ibidem, $§ 67-68$, p. 141-144. Cf. também Edmund Husserl, Die Idee der Phänomenologie, p.58: "Tudo na pura intuição. Ela não teoriza e não matematiza; a saber, ela não consuma nenhum esclarecimento no sentido das teorias dedutivas (...) Este intuir evidente é, ele mesmo, o conhecimento no mais amplo sentido". Cf. Jean-Luc Marion, Reduction and Givinness, p. 9-15. Para Eckhart, todo encontro com Deus que fosse promovido por subterfúgios lógicos não passaria de um contra-senso. Como o pensamento
} 
"intuição divina de tudo" (göttliche Allerschauung) que sedimentava o caminho para a passagem do absolutus da redução para a apreensão do absoluto do sentido de ser em sua máxima pureza.

Mas se é verdade que a conservação do preceito cartesiano da eversio afasta cada vez mais a fenomenologia transcendental das Meditationes, a ponto de colocá-la na extravagante companhia dos Sermões, isto não significa que a orientação fenomenológica seja literalmente um êxtase e que, cedo ou tarde, venha a reconhecer piedosamente o “amor desinteressado e justo" como uma noção fundamental. Não nos enganemos: Husserl jamais proferiu homilias acerca de "um amor sem porquê", mas sempre fez questão de acentuar que a fenomenologia era a "ciência rigorosíssima" donde emanavam "as puras normas da razão"129. Ainda que fonte de preciosas lições filosóficas, aquela inspiração pouco ortodoxa para uma teoria do conhecimento não deixaria de sentir os efeitos mordazes da purgação fenomenológica. Daí a razão pela qual a "ciência rigorosa" não poderá acatar o veredicto da mística: embora ambas estivessem de acordo quanto ao fato de que o absoluto do sentido se desvelava no absolutus da pobreza, para a fenomenologia tudo se passava como se este absoluto do sentido não pudesse ser Deus. Aos olhos de Husserl, não era porque este Deus não se deixava apreender pelo conhecimento por meio de "perfis" ou "silhuetas", tal como a coisa física, que Ele necessariamente gozaria da mesma condição absoluta da apreensão das vivências. Muito embora Deus diferisse de todas as coisas quanto ao seu modo de doação, esta condição não era suficiente para elevá-lo à posição de sentido e ainda o acomodava junto ao mundo sob a rubrica de "transcendente" - afinal, como bem se sabe, desde A idéia da fenomenologia o absoluto do sentido residia na noção de "imanência autêntica", quer dizer, era próprio da consciência que apreendia a si mesma de modo puro, alheia à toda interferência daquilo que a excedia. Que outrora Deus tenha sido sinônimo de absoluto por conceder sentido à existência das criaturas por meio de amor e graça, ou que tenha figurado, enquanto summe bonus, omnipraesens e omnipotens, como o fiador da relação da res cogitans com a res extensa, isto já pouco importava para a fenomenologia pura.

dedutivo se esgota, com ele se esgota um Deus que, por definição, deveria ser inesgotável. Deste modo, o místico colocava o lógico em dificuldade nas regras de seu próprio jogo: "O homem não deve deixar-se contentar apenas com um Deus inteligível, pois o pensamento se esgota; e assim também se esgota Deus. É necessário possuir um Deus essencial, o qual está acima do mero pensamento do homem, acima de todas as criaturas. Este Deus não se esgota (...) deve-se somente contemplar (schauen) Deus". Meister Eckhart, Deutsche Mystiker des 14. Jahrhunderts, Band 2: Meister Eckhart, p. 548.

${ }^{129}$ Idem, Philosophie als strenge Wissenschaft, §1, p. 7. Sobre o "amor desinteressado" (diu minne enhât kein warumbe), cf. Meister Eckhart, Predigten, Predigt XXVIII, p. 316. 
No mais generoso dos casos, restava-lhe ali a condição de "absoluto" apenas por homonímia, “um 'absoluto' num sentido totalmente diferente do absoluto da consciência, assim como um transcendente num sentido totalmente diferente do transcendente no sentido do mundo"130. E no menos generoso deles, seu rebaixamento à mera fórmula comprobatória das puras visadas do verdadeiro absoluto: "mesmo Deus está sujeito a esta necessidade absoluta e evidente, assim como à evidência de que $2+1=1+2$. Também ele só poderia alcançar conhecimento de sua consciência e de seu conteúdo reflexivamente" 131 .

Mas se em regime de redução Deus figura como transcendente e é a consciência transcendental que responde pelo questionamento fenomenológico do absoluto, em que sentido ela o faz? O ser absoluto da consciência, dirá Husserl, somente pode ser compreendido a partir da possibilidade de não ser (die Möglichkeit des Nichtseins) que repousa na essência do mundo transcendente: sempre sujeita à inadequação e às modificações que emergem do curso da própria percepção, toda doação do mundo será volátil, quer dizer, numa espécie de lição retida das Meditationes, se reconhecerá que na essência da percepção reside a possibilidade do "não ser percepção". Era o que enunciava Descartes em sua primeira meditação:

“Quão freqüentemente o sono noturno não me persuadiu dessas coisas usuais, isto é, que eu estava aqui, vestindo esta roupa, sentado junto ao fogo, quando havia, no entanto, deposto as vestes e estava deitado entre cobertas (...) Quando penso mais atentamente, vejo de modo tão manifesto que a vigília nunca pode ser distinguida do sono por certos indícios, a ponto de que fico estupefato e esse mesmo estupor quase me confirma a opinião do sonho" ${ }^{" 132}$.

Aquelas percepções das vestes sobre o corpo e do fogo da lareira a iluminar e aquecer, aparentemente tão claras e distintas, revelavam-se uma doação doutro gênero “percepções” enganosas que, na verdade, consistiam em alucinações, ilusões...um sonho.

\footnotetext{
${ }^{130}$ Idem, Ideen I, §58, p. 125.

${ }^{131}$ Idem, Ibidem, § 79, p. 175. Cf. Edmund Husserl, Die Idee der Phänomenologie, p.57: "Poderia uma divindade, um intelecto infinito, obter mais da essência do vermelho do que aquilo que intui de modo geral?". Cf. Emmanuel Lévinas, Reflexões sobre a "técnica" fenomenológica, in: Descobrindo a existência com Husserl e Heidegger, p. 138.

132“Quam frequenter vero usitata ista, me hic esse, toga vestiri, foco assidere, quies nocturna persuadet, cum tamen positis vestibus iaceo inter stracta (...) Dum cogito attentius, tam plane video nunquam certiis indiciis vigiliam a somno posse distingui, ut obstupescam, et fere hic ipse stupor mihi opinionem somni confirmet". René Descartes, Meditationes, Med. I, p. 24. Cf. Gérard Lebrun, A noção de "semelhança" de Descartes a Leibniz, in: A filosofia e sua história, p. 433-450.
} 
Todavia, à diferença de Descartes e sua desqualificação das percepções como conhecimento em sentido estrito, a fenomenologia ensinará que esta ausência de absoluta certeza no modo de ser reflete a "necessidade de essência" da apreensão do mundo ele mesmo. Ou seja: o mundo que a orientação natural outrora supôs ser um inabalável fundamento trazia agora, na visada de Idéias $I$, o relativo como mácula originária, numa irremediável possibilidade de não ser. Em contrapartida, a consciência rechaçava totalmente esta possibilidade, pois "na esfera absoluta, não tem espaço nenhum conflito, aparência ou ser-outro. É a esfera de uma posição absoluta" ${ }^{133}$. Uma vez que ela sempre é na pura doação de si mesma, a possibilidade de não ser simplesmente desvanece, levando consigo a carência de algum outro modo de ser para que a consciência seja assegurada. E se é assim, aquele tradicional ser real do mundo não somente deixa de ser necessário ao ser da consciência, mas se torna relativo a ela enquanto transcendente

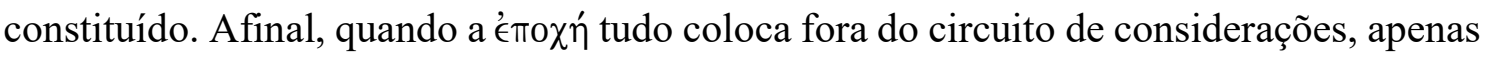
a consciência transcendental resiste à invectiva e firma-se como doadora absoluta de sentido a tudo aquilo que foi, que é e que virá a ser; seu modo de ser é tal, que sequer a inexistência da "coisa transcendente em geral" pode afetá-lo ou criar-lhe dificuldades. Em suma, dirá Husserl, “o ser imanente é, portanto, indubitavelmente ser absoluto no sentido de que ele, por princípio, nulla 're' indeget ad existendum (não carece de coisa alguma para existir)" ${ }^{\prime 134}$.

Contudo, diante disso, o leitor ainda poderia se indagar com razão: se é verdade que esta noção de consciência transcendental, alcançada por uma eversio profundamente radical, já não deveria ser confundida com a noção de mens sive animus sive intellectus, o que dizer destas núpcias tardias que pareciam se consumar com a filosofia cartesiana sob a forma de uma citação latina? Na realidade, esta consumação jamais existiu, pois a maneira pela qual Husserl empregava e modificava a passagem não fazia senão afastá-lo de Descartes. Prova disto se encontra na leitura dos Principia Philosophiae. Quando ali se afirmava que "por substância não podemos entender senão a coisa que existe, a fim de que não careça de nenhuma outra coisa para existir" (per substantia nihil aliud intelligere possumus, quam rem quae ita existit, ut nulla alia re indegeat ad existendum) ${ }^{135}$, certamente esta proposição não estava remetida à cogitatio. A substância referida por Descartes deveria, sem dúvida, respeitar o postulado, mas sem que com isto contrariasse

\footnotetext{
${ }^{133}$ Edmund Husserl, Ideen I, §46, p. 98.

134 Idem, ibidem, \$49, p. 104.

${ }^{135}$ René Descartes, Principia Philosophiae, pars prima, §51, p. 24.
} 
um axioma previamente estabelecido: ex nihilo nihil fit ("nada é feito a partir do nada") Havia algo capaz de atender tais exigências senão Deus? Ora, nada além Dele apresentava a possibilidade de não carecer de coisa alguma para existir e simultaneamente de não contrariar a verdade que impossibilitava a proveniência do nada. E se as Meditationes em algum momento denominaram a res cogitans e a res extensa como substâncias, não foi por falta de escrúpulo ou por algum deslize lógico da acies mentis (agudeza do intelecto). Tanto uma quanto outra bem podiam ser compreendidas sob este conceito comum e, à primeira vista, análogo àquele de Deus desde que respeitassem a seguinte ressalva: uma vez que ambas não se deixavam determinar pelo nulla alia re indigeat ad existendum, mas pelo "solo Dei concursu egent ad existendum" 137 , estas res mereciam a nomenclatura de substantiae somente porque eram entendidas como creatae (criadas), relativas ao creator absoluto. Husserl, por sua vez, distribuía os acentos de forma bastante diversa, a começar pelo já notado fato de que o absoluto fenomenológico não coincidia com a figura de nenhum Deus transcendente. Além disso, antes de se definir por meio do "nulla alia re...", a imanência transcendental da consciência apresentava-se numa fórmula que, embora mais concisa, não era menos profunda: "nulla 're' indigeat ad existendum". Ao grafar o termo " $r e$ " entre aspas, a lição que Idéias I pretendia transmitir a todo fenomenólogo era que a consciência não só não dependia de nada de real para que pudesse ser, como também o real ele mesmo já não refletia nenhuma independência ontológica que assegurasse à res seu significado habitual. Não há a tradicional realitas da res - e as aspas são as marcas de seu desvanecimento. O que há é a coisa enquanto correlato, um mundo cujo "em si”" a redução esvaziara e revelara ser o relativo que cogitatione indeget ad existendum (carece da consciência para existir). Quer dizer, o que há, portanto, é a consciência como absoluto, não aferrada ao mundo, mas dele independente e constituinte - e "além disso, um nada" (darüber hinaus aber ein Nichts ist). ${ }^{138}$ E é por esta razão que Husserl definirá a fenomenologia como uma investigação das "irrealidades": a tarefa não mais se cumprirá como descrição das vivências de uma consciência imersa na realidade, mas de uma consciência transcendental purificada e constituinte do "real" ele mesmo, uma verdadeira doadora de sentido de tudo aquilo que foi, de tudo aquilo que é e do que poderá vir a ser. ${ }^{139}$

\footnotetext{
${ }^{136}$ Idem, Ibidem, pars prima, §49, p. 23.

${ }^{137}$ Idem, Ibidem, §52, p. 25.

${ }^{138}$ Edmund Husserl, Ideen I, §49, p. 106.

139 “'Mostrar-se-á que todas as 'vivências' transcendentais purificadas são irrealidades apartadas de todo enquadramento no 'mundo real'”. Idem, Ibidem, Einleitung, p. 7.
} 
Esta vigência da consciência absoluta como único sentido de ser possível ainda iria exumar uma questão que a fenomenologia parecia ter definitivamente resolvido já em seu momento pré-transcendental. Sob a forma de escusas dirigidas a Natorp por críticas precedentes $^{140}$ e numa solene retratação das Investigações Lógicas, Husserl confessará em Idéias I a inevitável necessidade do tratamento o eu na descrição da consciência. Se na Quinta Investigação o eu era negado em termos absolutos em favor do jorro ininterrupto da multiplicidade das vivências, a fenomenologia transcendental irá questioná-lo apenas em sua fixidez substancial: para ela, o eu deveria ser destituído de seu papel de idéia fixa, a fim de que pudesse ser compreendido em seu semblante puro, isto é, em sua constância. Afinal, este "ego autêntico" não podia partilhar da necedade com a qual Descartes dava a conhecer o ego na segunda meditação. Antes de ser o grão primigerador estático da metafísica, o ego transcendental era, na verdade, extático e fluido como as próprias vivências do fluxo, um Blickstrahl que "muda a cada cogito, iluminando-se novamente a cada novo cogito e desaparecendo com ele"141. Ele não se define pela rigidez da substância, mas nasce e finda a cada vez, vem e, após vir, escoa juntamente à vivência. E se é assim, dirá Husserl, as vivências mesmas lhe "pertencerão" na justa medida em que elas se apresentam como o "fundo de consciência" que o possibilita ${ }^{142}$. É neste sentido de ser possibilitado e simultaneamente "conter" (quer dizer, de lá estar sem ser propriamente uma vivência) que o ego fenomenológico será uma transcendência na imanência: não podendo ser comparado à transcendência de qualquer objeto, já que não se deixa afetar pela redução, o "eu transcendental" será uma transcendência sui generis porque não constituída, mas constituinte, estando sempre ali como ein Identisches (um idêntico). E neste "estar sempre ali" é que a fenomenologia poderá enfim falar de uma imortalidade do ego. Não aquela immortalitas animae com um eco teológico que emanava das Meditationes, mas uma "imortalidade" própria da temporalidade imanente da consciência. Enquanto um objeto apreendido por uma vivência tem uma duração e, por isto mesmo, chega a termo, a consciência, ao ser entendida como a duração, não termina; a uma vivência presente que se esgota, tornandose passada, há sempre uma nova vivência presente a lhe ocupar o posto. Nesta sucessão de "durações" que principiam e findam, a duração ela mesma é ininterrupta: "a duração

\footnotetext{
${ }^{140}$ Idem, Logische Untersuchungen, V, §8, p. 359-363.

${ }^{141}$ Idem, Ideen I, $\$ 57$, p. 123.

${ }^{142}$ Idem, Ibidem, §80, p. 179.
} 
é "imortal""143. Ela em nada condiz - afirmará Husserl - com este "tempo cósmico" objetivo, mensurável por artifícios cronométricos de ciências que, bem ao gosto de Descartes, acreditavam ingenuamente que "todo o tempo da vida pode ser dividido em inúmeras partes, cada uma das quais não dependendo de modo algum das outras" (omne tempus vitae in partes innumeras dividi potest, quarum singulae a reliquis nullo modo dependet $[. .].)^{144}$. Não se trata apenas de dizer que ela não pode ser medida "por meio de horas" ou "pela posição do sol", mas trata-se de reconhecer que ela não pode ser medida em geral. Duração aqui nada mais é do que aquele "flutuar que percorre diferentes dimensões"145, a Urquelle alcançada pela redução e para a qual não há nem princípio nem fim. Pode-se bem dizer que há um término no processo, mas jamais um término do processo do fluxo de consciência; pode-se pensar, assim, um começo no processo, sem que se possa pensar um começo do processo. Eis aí um problema filosófico antiqüíssimo: mesmo que se oponha ao argumento da ausência do início do fluxo transcendental a afirmação de que o nada precede o princípio, pode-se dizer que este nada já é alguma coisa. Pouco importa quão empenhada seja a tentativa de provar que ao princípio antecede um vazio, "ein indifferentes, eintöniges, stummes Dämmern", pois ele também será um passado, imerso na "estrutura essencial do temporal". Assim sendo, é no seio da fenomenologia íntima do tempo que Husserl poderá anunciar a tese da imortalidade do eu puramente transcendental: enquanto ao homem no interior do mundo estão reservados tanto o momento de seu "vir-ao-mundo" no nascimento quanto o "deixar-o-mundo" na ruína da morte, o eu puro é infinito nos horizontes do passado e do futuro e no momento originário do agora. "Dito por princípio, a alma do corpo não é imortal, isto é, não é necessário que ela se pense como imortal, e ela realmente morre segundo a experiência cotidiana. Mas todo homem-eu guarda em si em certo modo seu eu transcendental, o qual não morre e não nasce: ele é um eterno ser no tornar-se" ${ }^{\text {"146. }}$

A lucidez com a qual Kierkegaard proferia as palavras definitivas que, no início, permitiam compreender a complexidade que permeava a relação entre as Meditationes de

\footnotetext{
${ }^{143}$ Idem, Analysen zur passiven Synthesis, Beilage VIII (\$46), p. 377.

144 René Descartes, Meditationes, Med. III, §36, p. 98.

${ }^{145}$ Edmund Husserl, Ideen I, $\S 75$ e $\S 81$, p. 156 e 182.

${ }^{146}$ Idem, Analysen zur passiven Synthesis, Beilage VIII (\$46), p. 381.
} 
prima philosohia e as Meditações cartesianas (além, é claro, das Investigações Lógicas) deve ser mais uma vez evocada, agora no desenlace, para que se possa enfim encerrar a questão. Escrevia ele em seu $O$ conceito de angústia: "Não basta ter as costas largas para ser Atlas, e ninguém se torna Atlas apenas por carregar o mundo"147. De que auxílio seria esta máxima kierkegaardiana? Ora, o que ela reflete é o seguinte: com base na relação que Husserl estabelece com Descartes desde o dilúculo de sua filosofia, a fenomenologia não pode ser dita cartesiana porque a função que cumpre sua eversio é atacar o fundamento das Meditationes; todavia, ela não deixa de ser cartesiana em alguma medida ao se servir deste preceito que Descartes trazia ao centro do proscênio contra o princípio da filosofia que o Teeteto e a Metafisica canonizavam, o $\theta \alpha u \mu \alpha ́ \zeta \epsilon \iota \nu$. Não se pode, com efeito, afirmar que Husserl é um cartesiano, assim como não se pode dizer que não o é plenamente. É um fardo de todo aquele que adota a eversio ser cartesiano sem sê-lo. E como a libra não pende para qualquer um dos extremos da interpretação, talvez seja de bom tom aos seus asseclas reconhecer que a situação da filosofia de Husserl é menos óbvia que suas leituras forçosas e suas vontades combativas. Não se pode defender que a fenomenologia seja apenas um louvor a Descartes ou um louvor da independência que se obtivera de seu filosofar sem que, com isto, se comprometa o elogio verdadeiramente conservado: eversionis laus (o elogio da eversio).

${ }^{147}$ Søren Kierkegaard, O conceito de angústia, p. 13. 


\title{
Capítulo 2
}

\section{Die erkannte Erkenntnis: a interpretação e a crítica de Heidegger à fenomenologia transcendental de Husserl}

\author{
"El prejuicio de no tener prejuicios es el más común de todos". Nicolás \\ Gómez Dávila, Escolios a un texto implícito. \\ "Silêncio tenso - como pausa de araponga". João Guimarães Rosa, \\ Ave, Palavra.
}

\section{I - O passado originário}

No momento em que se concebe o teor da relação estabelecida entre as filosofias de Husserl e Descartes, sua determinação precisa não deixa de rememorar, seja em agudeza ou em seu teor um tanto esquizofrênico, a resposta que Tales dera àquele que lhe questionara - de maneira capciosa, é verdade - o que se fizera primeiro, a noite ou o dia:

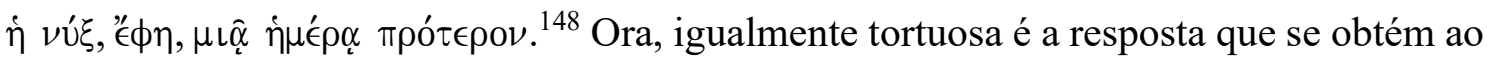
indagar qual é a situação na qual se encontra a fenomenologia em face do cartesianismo. Pois se é verdade que desde as Investigações Lógicas a dita "exclusão de pressupostos" sempre acompanhou cada nova formulação do pensamento husserliano, é também verdade que ela se provava impossível tão logo surgia com a pretensão de assegurar o mais claro e distinto dos caminhos para uma ciência absoluta e rigorosa. Afinal, como seria possível para esta ciência afastar de si toda e qualquer pressuposição quando o próprio preceito da eversio já se provava uma pressuposição extraída das páginas das Meditationes? Estenda o fenomenólogo este rito de purificação tanto quanto queira - ele jamais será capaz de exorcizar este demônio cartesiano que assola sua reflexão. Eis aí a situação desconcertante que aproximava a fenomenologia da engenhosa resposta proferida pelo filósofo grego: todo o reiterado esforço em purgar-se de qualquer resquício de ingenuidade perpetrado pela história da filosofia ocorria por obra da tese cartesiana da qual ciência alguma com pretensões absolutas poderia prescindir. E "como a noite que antecede o dia por um dia", a fenomenologia será cartesiana justamente por não sê-lo.

148 “A noite antecede por um dia”. Diógenes Laércio, Vitae Philosophorum, I, 36, 2-3. 
Atuando a eversio como sua guia, cada passo dado pela fenomenologia com o intuito de afastar-se de Descartes significava uma aproximação.

Dada a particularidade do problema e seu caráter fundamental para o próprio pensamento fenomenológico, é natural que se pergunte: em algum momento a crítica se impôs a tarefa de investigar esta relação sui generis e seus desdobramentos ou sua situação fora sempre aquela de supor a importante presença das teses cartesianas para a fenomenologia, mas sem jamais analisá-las, reduzindo-as à mera menção ligeira? Na verdade, pouco demorou para que este aspecto comprometedor situado no cerne do pensamento fenomenológico pudesse enfim vir à luz. Fora num de seus cursos ministrado em Marburg - intitulado Introdução à pesquisa fenomenológica - que Heidegger expusera tal questão à sua audiência. Convicto desde o princípio da preleção que "não ter nenhum pré-juízo é o maior de todos os pré-juízos"149, ele irá ali investigar, antes de tudo, de que maneira a consciência purificada, resultante da eversio, torna-se o tema por excelência da filosofia. Torna-se porque, não obstante seu papel fundamental para os filósofos que ainda hoje dela se ocupam, esta "consciência" jamais fora conhecida pelos gregos. Perguntar-se-ía então: sequer no De Anima? Nem mesmo ali, uma vez que a simples questão do modo de apreensão da própria percepção tomava um aspecto

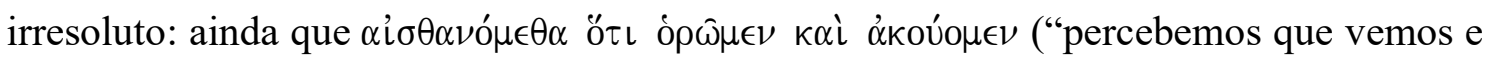
ouvimos"), não podemos determinar por qual meio a visada é capaz de ver a si mesma,

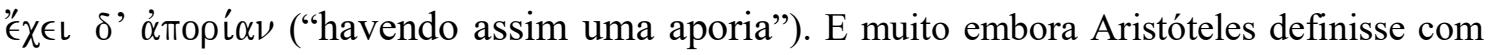
presteza tò $\pi \rho \alpha ́ \gamma \mu \alpha$ (o ente para o qual se volta a preocupação na relação), o homem e o $\lambda o ́ \gamma o \varsigma$ (o deixar ver enquanto tal), sua filosofia não podia concebê-los na unidade de "um fenômeno fundamental característico" simplesmente porque uma decisão de princípio já havia lhe turvado a visada ${ }^{150}$. Quer dizer, enquanto a oủoí $\alpha$ (substância) figurasse como o caráter fundamental do ente em seu ser, atraindo consigo toda a preocupação para o mundo, a filosofia grega jamais adotaria como tarefa o esclarecimento daquela consciência voltada para si mesma.

Se não por obra do engenho grego, como então surge a consciência na cena filosófica? E o que teria a fenomenologia a ver com ela? Ora, dirá Heidegger, a fenomenologia não apenas surge nesta narrativa enquanto expressão última daquilo que se designa pela noção de consciência, mas surge porque ela mesma, no desdobramento

\footnotetext{
${ }^{149}$ Martin Heidegger, Einführung in die phänomenologische Forschung, GA 17, Vorbemerkung, p. 2.

${ }^{150}$ Aristóteles, De Anima, III, 425b 12-22. Cf. Martin Heidegger, Ibidem, §2d, p. 35.
} 
de sua tarefa, é a expressão de uma preocupação (Sorge). Não uma preocupação em sentido habitual, é verdade, mas um preocupar-se devidamente filosófico, entendido como abertura daquele que se preocupa e a explicitação do ente "preocupado"; este preocupado explícito, por sua vez, deve conservar-se tal e qual é, para que aquele que com ele se preocupa possa enfim nele perder-se, fazendo deste preocupado o fundamental que motiva toda a preocupação. E qual não será esta famigerada preocupação da fenomenologia senão aquela por um "conhecimento conhecido" ("die erkannte Erkenntnis") que se estabelece como ciência absoluta e como ponto determinante de uma cultura fundada na razão. Não parece haver dificuldade em reconhecer como Husserl "conserva", "explicita" e "perde-se" nas veredas do preocupado que dá sentido à construção do edifício teórico de sua disciplina: não chega a ser necessária uma frequentação assídua da obra para que logo salte à vista, naquela Klarheit incomparável, o conhecimento apreendendo a si mesmo, findando com todo e qualquer enigma persistente em sua esfera e cultivando assim o terreno teórico onde a noção de consciência

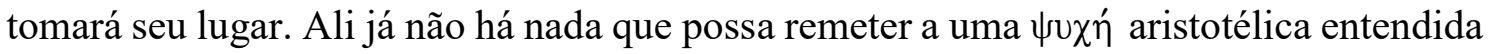

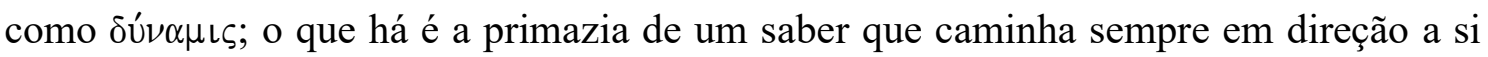
mesmo, sem reservas ou obstruções, preocupando-se apenas com o ser enquanto consciência e não com "ente enquanto mundo" (das Seiendes als Welt): "a preocupação concreta, que conduz à formação da consciência como tal enquanto campo temático, que a indica e a coloca como tema ulterior da filosofia, é preocupação com o conhecimento conhecido; e é deste modo que o conhecer do conhecer torna-se identificado e identificável a partir de um solo enfim assegurado" ${ }^{151}$.

O leitor de Husserl terá, contudo, boa razão em questionar se uma interpretação de sua filosofia portaria consigo alguma legitimidade caso fosse levada a termo sob os auspícios do conceito de preocupação. Até que ponto - deve-se certamente perguntar esta compreensão da fenomenologia como preocupação com o "conhecimento conhecido" não terminaria por ferir o sentido da própria reflexão husserliana, numa espécie de impostura do discípulo frente ao mestre? Em sentido nenhum, responderia Heidegger, já que era o próprio Husserl a nos remeter à sua presença no cerne do pensamento fenomenológico. Sua menção podia ser encontrada em meio às teses expostas em Idéias I. Dizia-se ali que a fenomenologia transcendental recém-surgida deveria contar com uma determinação "cética” fundamental, quer dizer, deveria desenvolver-se,

${ }^{151}$ Martin Heidegger, Ibidem, §7, p. 62 e Ergänzung 4 (§2c), p. 295. 
desde o princípio, apartando-se da totalidade dos ingênuos juízos dados de antemão e relacionando-se apenas com a evidência absoluta das vivências. Para que a fundação fosse autêntica e digna do nome de teoria do conhecimento, ela exigia total clareza na apreensão do ato de conhecer, sem que nada viesse conspurcar-lhe a visada. Estes eram os princípios de seu método; esta era sua preocupação fundamental:

"Por estas razões, os preocupados esforços (die sorgsamen Bemühungen) para chegar à evidência sobre os componentes fundamentais do método, ou seja, sobre aquilo que é metodologicamente determinante para a nova ciência, desde o seu início e por todo o seu percurso, têm para a fenomenologia uma significação totalmente diferente daquela que os esforços análogos poderiam ter para outras ciências". ${ }^{152}$

Ledo engano supor que a "nova ciência" nascida da pena de Husserl não contava com aquela preocupação característica. Não havia eversio que pudesse apartá-la do jogo filosófico, uma vez que o "preocupar-se com o conhecimento conhecido" era, efetivamente, o que lhe concedia sentido. Pois ao insistir em trazer o fundamento à tona, desenterrando-o da pilha de escombros que a história da filosofia sobre ele depositara, a eversio somente podia fazê-lo porque "conhecer verdadeiramente o conhecimento" já residia no horizonte da preocupação. Eis aí algo que a preleção Introdução à pesquisa fenomenológica não cessava de rememorar: a consciência em seu apogeu fenomenológico, dada na pureza proveniente da exclusão de pressupostos, formulava-se graças à abertura que a preocupação com o conhecimento conhecido lhe proporcionava.

Mas se parece coisa bem compreendida que dos ditos da fenomenologia se extrai a confissão de que a determinação de sua doutrina se consuma a partir de uma preocupação com conhecimento conhecido, resta saber como ela alcança o cimo das expressões desta mesma preocupação. Pois bem: como a fenomenologia se molda com tamanho grau de pureza? Muito embora fosse ela similar àquela clássica preocupação com o conhecimento conhecido por conta de seu nome, a nova ciência husserliana trazia em si uma marca distintiva; ainda que seguisse um "curso tradicional", que em seu tempo encontrava expressão na psicologia empírica e na teoria das ciências, ali se mostrava algo de modo completamente original, algo que "na elaboração da consciência na direção da clarificação da crítica do conhecimento trata, antes de tudo, de trazer em si mesmo à

${ }^{152}$ Edmund Husserl, Ideen I, §63, p. 137. 
visada o que há de se elaborar" ${ }^{\prime 153}$. E esta originalidade estará situada naquilo que fará da fenomenologia uma "cientificidade última", segundo a qual "a intenção e a ideia de uma elaboração científica da consciência" ${ }^{154}$ tornam-se absolutas e passam a reunir obrigatoriamente a totalidade dos entes (aos quais a consciência serve de fundamento) sob seus cuidados e suas regras: para que sua questão essencial não descarrilasse em direção à antiquada questão pelo que é, mas sempre buscasse responder como tudo aquilo que é pode ser evidentemente conhecido, era exigido do fenomenólogo que conservasse um irretorquível rigor em sua investigação. O original era, portanto, o rigor por meio do qual a preocupação inicial com o conhecimento conhecido passava a tomar a forma da mais pura das disciplinas - e que não por acaso, dirá Heidegger, fará sua estreia na cena filosófica na obra que carrega o título bastante sugestivo de Filosofia como ciência rigorosa. Afinal, se os discípulos de Husserl já ouviam pacientemente suas considerações acerca da noção de rigor desde as preleções de $A$ ideia da fenomenologia, era apenas ali, no longo artigo originalmente publicado na revista Logos, que o grande público dela tomaria conhecimento. Com qual traçado, então, se delineava o conceito de rigor em Filosofia como ciência rigorosa? Aos olhos de Heidegger, a essência do rigor não será senão a seriedade com a qual uma determinada preocupação está voltada àquilo com o que ela se preocupa. No caso de Husserl, esta seriedade certamente grassa, ininterrupta, até a fundamentação autêntica do saber, não se detendo até que esteja em posse da "coisa mesma". E embora esta seriedade tenha sempre a acompanhar seus passos a velha necessidade de se caracterizar como ciência, ela não partilhará da definição de "seriedade dedutiva" que a moderna preocupação com o conhecimento conhecido sempre aliava à cientificidade. Fenomenólogo algum podia se render à ideia demasiadamente ingênua de que aquela amálgama puramente matemática entre ciência e dedução era justificável em sua regência absoluta; supô-la significava, antes de tudo, dissimular um preconceito e estender uma acrisia: "não somente aqui, mas em toda nossa história da ciência, a ideia matemática de rigor foi posta acriticamente como norma absoluta". ${ }^{155}$ Se bem compreendida, esta "seriedade dedutiva" sequer chega a ser merecedora do nome que carrega, uma vez que invade um âmbito que não é o seu e apodera-se de uma questão que não lhe concerne. Quando Descartes, por exemplo, acreditava poder encontrar o seguro fundamento da ciência graças àquela seriedade dedutiva, sua filosofia era rigorosa apenas

\footnotetext{
${ }^{153}$ Martin Heidegger, Einführung in die phänomenologische Forschung, GA 17, §6b, p. 59.

154 Idem, Ibidem, GA 17, §9, p. 71.

155 Idem, Ibidem, GA 17, §15c, p. 103.
} 
em aparência. Na realidade, o "rigor matemático" provocava um extravio ao servir-se de uma ideia intrusa que, antes de reforçar a seriedade, marcava sua ausência. A verdade sobre o autêntico rigor é bem outra. Para que uma ciência pudesse ser dita de fato rigorosa, a ela nada poderia ser atribuído "de fora", "mas deveria ser formado e tomado a partir da ciência mesma enquanto descobrimento do ente". ${ }^{156}$ Nichts von außen her: nenhuma surpresa, portanto, que a fenomenologia seja a única merecedora da alcunha. Tudo se passa como se ela, e mais nenhuma outra, fosse capaz de cumprir a promessa da preocupação com o conhecimento conhecido de modo autêntico e na mais elevada medida; por obra de uma rígida exclusão de pressupostos e de uma amplíssima intuição sem mediações, retornava-se, agora sim, às coisas mesmas e erigia-se - bem ao gosto de Husserl - uma ciência verdadeiramente rigorosa.

Como bom sequaz do preceito da eversio, Husserl conhecia o perigo das ingênuas tentações que emanavam da tradição e ameaçavam o rigor da ciência. Não permanecesse ele contumaz em sua exclusão de pressupostos, a ideia de elaboração científica de uma consciência absoluta certamente falharia - e falharia porque a intervenção de qualquer pressuposto traria consigo um enigma $(\alpha \rrbracket \nu\llcorner\gamma \mu \alpha)$, um obscurantismo alastrado por toda história da preocupação com o conhecimento conhecido, “um pré-juízo da maneira mais perigosa" (ein Vorurteil gefärhlichster Art). Ora, era justamente para delimitar a fronteira que a separava das obnubiladas teses tradicionais sobre a consciência que a fenomenologia clamava por uma clarificação (Klärung) muito específica: "A crítica se consuma no modo da clarificação dos problemas". ${ }^{157} \mathrm{O}$ que é, todavia, uma clarificação dos problemas? Ou melhor: o que é um problema e no que consiste sua clarificação? Um problema, dirá Heidegger, não é senão "uma pergunta formada em modo determinado e expressamente colocada" ${ }^{158}$, isto é, uma pergunta que ao exigir e ser digna de uma resposta é em si a expressão de uma tarefa. Enquanto tal, ela deve colocar uma questão que seja autêntica, deve estabelecê-la e entendê-la como procura. Não uma procura que se porte como um fenômeno meramente teórico, numa busca simples, onde a pergunta seja corriqueira e despretensiosa. Nada disso. A procura é algo fundamental, uma vez que aquele que procura, preocupa-se desde o princípio. O procurar será, portanto, "uma preocupação determinada" - o que, no caso de Husserl, faz da preocupação uma "preocupação com o conhecimento conhecido". E sendo a clarificação a reiterada

\footnotetext{
${ }^{156}$ Idem, Ibidem, GA 17, §15c, p. 103.

${ }^{157}$ Idem, Ibidem, GA 17, §9, p. 72.

${ }^{158}$ Idem, Ibidem, GA 17, §10a, p. 73.
} 
exigência fenomenológica de purificação em vista da "obtenção de uma evidência e uma certeza absolutas" "159, a clarificação dos problemas corresponde à purificação da preocupação com o conhecimento conhecido, quer dizer, como a expressão definitiva do âmbito da consciência, completamente livre dos descaminhos inculcados pelo próprio pensamento filosófico no curso histórico desta preocupação. Ou nas palavras de Heidegger: "Esta purificação da tendência é sua Verabsolutierung". ${ }^{160}$

Mas se é verdade que a fenomenologia, por seus próprios méritos, é entendida como o traço perfeito e a palavra peremptória da preocupação com o conhecimento conhecido, não é igualmente verdadeiro que ela seja sua única expressão. Caso supuséssemos que somente ela fosse a expressão desta preocupação, seríamos conduzidos à crença absurda de que esta doutrina (definida desde o princípio como purificação dos extravios da tradição e como ponto mais elevado das considerações acerca do “conhecimento conhecido"), antes de ser a herdeira dileta da questão, era sua fundadora. Uma tese tão abstrusa que de pouco carecia para que fosse refutada: bastava compreender que a própria noção de purificação já significava que o pensamento fenomenológico surgia como o representante último de uma linhagem porque cumpria a promessa de uma preocupação histórica, grafada - digamos de uma vez! - naquele simplório latim do século XVII. Contudo, se esta suposição não passava de um pensamento vulgar e de um grande ato de toleima, ao qual todo bom juízo evitaria recorrer, por que dela se faziam tantas menções em Introdução à pesquisa fenomenológica? Por um simples motivo: apesar de insensato, este contra-senso não era nada incomum. E a razão para isto encontrava-se naquela dominação (Herrschaft) que a preocupação com o conhecimento conhecido exercia no ato de perguntar da própria filosofia de seus contemporâneos. Dominação sufocante, que não fazia senão reiterar a exigência e promover uma imoderada necessidade de Klärung, levando-a a esquecer da historicidade da própria preocupação. Sem hesitação - dizia Heidegger ao constatar a situação inquietante buscava-se por clareza absoluta; ignorava-se, todavia, que clareza demais é também causa de cegueira. "A preocupação com o conhecimento conhecido mostra uma dominação que não é mais controlável, que está desenraizada, que não conhece mais a sua origem. Vivese na tendência de tratar a consciência como tema fundamental. Para a preocupação com o conhecimento conhecido, seu próprio ser não é mais evidente". ${ }^{161} \mathrm{Na}$ tentativa de

\footnotetext{
${ }^{159} \mathrm{Idem}$, Ibidem, GA 17, §9, p. 72.

160 Idem, Ibidem.

${ }^{161}$ Idem, Ibidem, GA 17, §19, p. 116.
} 
iluminar os recônditos obscuros, a dominação do perscrutar as reentrâncias de uma consciência absoluta e anistórica acabava por subtrair o solo onde a preocupação fincava suas raízes. E não se tratava de um desenraizamento singular, afetando somente a "preocupação com o conhecimento conhecido", mas de um desenraizamento da preocupação em geral, já que a ânsia da clarificação avançava em detrimento de seu ser. Os muito afoitos com a descrição do campo da consciência pareciam então tergiversar a um aspecto fundamental da própria tarefa: eles insistiam em não compreender que aquela visada da preocupação com o conhecimento conhecido jamais poderia ser autêntica enquanto sua origem permanecesse velada. Assim sendo, faltava-lhes entender que "toda preocupação é fática em seu ser, isto é, que à essência (Wassein) da preocupação pertence a concreção fática de seu ser"162 - e que, por esta razão, também a filosofia de Husserl tinha um passado originário (die ursprüngliche Vergangenheit).

Para aqueles que não se submetiam à dita dominação e não se contentavam com uma descrição que abdicava da facticidade da preocupação, os traços da origem transpareciam desde o princípio. Quem não turvava propositadamente a própria vista diante da história da filosofia, enxergava sem grandes dificuldades o momento do passado originário. Afinal, as referências claras sobre ele surgiam, ao menos, desde as primeiras páginas das Investigações Lógicas: não se contentando apenas em afirmar que a apreensão da essência dos atos nada conservava daquela singularidade natural própria da psicologia, Husserl estendia ali a dissociação e marcava sua purificação ao dizer que as essências fenomenológicas não se deixavam confundir com "essências anímicas" (die "seelischen Wesen”), quer dizer, embora a clássica cogitatio merecesse todo reconhecimento por possibilitar a abertura deste novo campo temático, a consciência em geral não era sinônimo de uma mens sive animus sive intellectus. ${ }^{163}$ Propondo-se a uma eversio dos prejuízos tradicionais do ato de conhecer, mas sem abandonar o aspecto fundamental da preocupação (isto é, seu caráter de unbedürftig, ou a capacidade do pensamento de voltar a si mesmo sem carecer de nada mais), a fenomenologia trilhava, apesar de seu posicionamento crítico, um caminho inaugurado pelas Meditationes. Neste sentido, quando se falava do retorno a um passado originário, nenhum outro nome ressoava que não fosse o nome de Descartes. E sobre este retorno ao "cogito, ergo sum", Heidegger esclarecerá não se tratar de uma despropositada demonstração de erudição

\footnotetext{
${ }^{162}$ Idem, Ibidem, GA 17, §16b, p. 106.

${ }^{163}$ Edmund Husserl, Logische Untersuchungen, II/1, Einleitung, §3, p. 9-12.
} 
filosófica, mas sim de uma necessidade para que se fizesse claro o movimento da própria preocupação: "Descartes e Husserl não são aqui exemplares quaisquer das presentificações do que nós expressamos sobre a preocupação, mas são as possibilidades de ser da preocupação mesma". ${ }^{164}$ Que ambos então surgissem como possibilidades de ser significava: nunca isoladamente dadas, nem a compreensão da origem, nem a compreensão da forma radical e pura; a evidência do ser próprio do conhecimento conhecido ocorria apenas na visada conjunta, no esclarecimento daquilo que essencialmente unia estas compreensões, daquilo que as fundamentava enquanto tais. Somente daí nascia o entendimento autêntico do "campo temático da consciência qua consciência" - e, a partir dele, observava-se o ligame que atava as filosofias de Husserl e Descartes uma à outra.

\section{II - O conhecimento conhecido}

Quando nenhuma autenticidade se deixava entrever na compreensão de uma preocupação com o conhecimento conhecido, regida pela aceitação cabisbaixa da dominação e cegada pela busca de clareza, carecia-se de um caminho que fosse capaz de conduzir verdadeiramente ao seu Ser. Caminho cujas primeiras passadas já indicavam tratar-se dum retorno: a fim de que a preocupação figurasse na plenitude de seu sentido, o que primeiro havia de se fazer era retornar ao seu passado originário, entendê-la em seu berço e em seus aspectos mais fundamentais. Assim, a intenção de elucidar autenticamente a esfera da consciência nos encaminhava a Descartes e buscava sorver das Meditationes a determinação daquele "domínio de ser" (Seinsfeld) que pela primeira vez se apresentava na história da filosofia. Então, de que maneira - perguntava-se Heidegger - o ser desta preocupação passava a exercer seu protagonismo na cena filosófica?

Como é bem sabido, a reflexão cartesiana tem início com o problema do falsum. O falsum é, por definição, o error (erro), o malum (mal) que nos desvia do verum iter (verdadeiro caminho): "O falsum não é nada senão o cavendum - isto que a preocupação com o conhecer tem que evitar". ${ }^{165}$ No princípio, não há nenhuma determinação positiva, mas sim uma ausência de positividade contra a qual o filósofo deve se precaver. Uma preocupação que não é em nada exagerada, afinal a ameaça real do erro encontra-se

\footnotetext{
${ }^{164}$ Martin Heidegger, Einführung in die phänomenologische Forschung, GA 17, §16b, p. 107.

${ }^{165}$ Idem, Ibidem, GA 17, §23, p. 131.
} 
sempre à espreita do saber, fazendo-se presente com constância e levando aquele que medita a reconhecê-lo como a primeira das constatações. Mas se o erro é notadamente um fato e sabemos que a ele estamos expostos, qual é, todavia, sua origem? Poderia eu afirmar sem receio que o erro tem sua causa em meu próprio ser, no fundamento de minha existência? O desdobramento meditativo demonstrará que a suposição aí presente é completamente descabida. Quando aquela "certa velha opinião, fixa em minha mente, de que há um Deus que tudo pode, e pelo qual fui criado tal qual existo" (infixa quaedam meae menti vetus opinio, Deum esse qui potest omnia, et a quo talis, qualis existo, sum creatus $^{166}{ }^{16}$, apresentada na primeira meditação, se provava uma ideia clara e distinta (nos esforços da terceira meditação), eu não somente entendo - dirá Descartes - minha condição finita e imperfeita, mas com ela noto também minha condição de creatus, isto é, noto que sou um efeito cuja causa é Deus em toda sua sumidade. Nesse sentido, não posso ser o fundamento de minha própria existência. Ou melhor: no momento em que tomo ciência da infinitude e da insigne bondade divina, reconheço que existo graças a elas e que o erro, entendido como malum, não pode compor tamanha perfeição originária. "Portanto, Deus existe e devo-lhe meu ser; assim, ele não pode ser a causa de que eu me engano. Nasce então a pergunta: se meu ser provém de Deus, donde vem o erro?"167.

Tendo em vista a questão, talvez poderia o bom aristotélico se apressar em condenar aquela frágil ruptura que o preceito da eversio instituía na história do pensamento filosófico: seja para a origem do verum quanto para a origem do falsum, não havia outra resposta possível senão aquela ofertada pelo De interpretatione, quer dizer, verum e falsum são encontrados somente no juízo. Seria o caso de conceder-lhe algum crédito, visto que Descartes jamais negou que elas lá estivessem. Contudo, deveríamos começar a desconfiar desta afirmação fundamentalmente grega tão logo compreendêssemos que o verum, no curso da reflexão cartesiana, "não está primeiramente orientado para o julgar, mas para o ente mesmo" ${ }^{168}$; nada impede que o verum esteja contido no juízo, ainda que esta não seja nenhuma necessidade para que ele venha a ser. A verdade deixa de exigir a obrigatoriedade do ato de julgar, carecendo apenas de uma clara et distincta perceptio do ente; ela antecede ao juízo para já se encontrar, de alguma maneira, na idea. E isto ocorre porque a ideia, quando observada por si mesma, não porta consigo nenhuma falsidade. Não visando nada além de si, ela

\footnotetext{
${ }^{166}$ René Descartes, Meditationes, Med. I, §9, p. 28.

${ }^{167}$ Martin Heidegger, Einführung in die phänomenologische Forschung, GA 17, §24, p. 134

${ }^{168}$ Idem, Ibidem, §24, p. 135.
} 
será sempre verdadeira. Pouco importa, escreve Descartes, se "imagino ou cabra ou quimera" (sive capram, sive chimeram imaginer) ou se "posso desejar estas coisas que não estão em parte alguma" (ea quae nusquam sunt possim optare), a ideia é um verum independente daquilo que nela deixa-se ver. Se posso então dizer que "não reconheço nenhuma desigualdade entre estas ideias, e todas parecem proceder de mim do mesmo modo" (non agnosco ullam inter ipsas [ideas] inaequalitatem, et omnes a me eodem modo procedere videntur), é em razão de observar tais ideias apenas enquanto repraesentans e não de acordo com suas repraesentata ${ }^{169}$. Para a terceira das meditações, portanto, não estava em questão o representado na ideia, mas a representação em si, já determinada em seu Ser como o grão primigerador, quer dizer, o representar do representado será sempre verdadeiro, uma vez que o conceito de verdade não reside inicialmente no conteúdo da ideia, mas na ideia ela mesma.

Isto significa que a presença marcante da veritas exclui por completo a falsitas do terreno das cogitationes e nos obriga a vasculhar alhures a origem do falsum? Não exatamente - e sobre isto Descartes será criterioso na exposição. É certo que a prova anterior já ensinava que a representação não pode comportar uma falsitas formalis porque a ideia em si é sempre verdadeira; no entanto, esta constatação não impedia a possibilidade de residir ali uma falsitas materialis ou a falsidade que é própria do representado. A ideia do frio, por exemplo, pode ajudar a compreender como o falso do representado pode ser encontrado na verdade da representação. Se sei, por obra do bom discernimento, que a ideia que possuo do frio é verdadeira enquanto tal, o mesmo não pode ser dito acerca de seu conteúdo, pois não faço senão proferir uma falsa sentença ao afirmar que sinto frio. Ora, "eu sinto frio" soa falso na medida em que o frio, sem que possa ser definido positivamente, é entendido como uma privatio, isto é, como a ausência do calor. Jamais posso dizer verdadeiramente que sinto frio, uma vez que isto significaria afirmar a existência e o Ser de algo que se determina por não Ser, seria referir-me à realitas de algo que, de fato, não a possui. Por mais que a representação recaia sempre sob a rubrica da veritas, seu representado dela não partilha: eis aí uma forma da cogitatio que carrega a possibilidade do defectus de trazer o não-Ser ao seio do Ser; eis aí a forma que carrega o nome de iudicium (juízo). Seria então o caso de reconhecer que o falso se encontrava no juízo, limitando ao verdadeiro a ruptura com a tradição aristotélica?

${ }^{169}$ René Descartes, Meditationes, Med. III, $\S 7-8$, p. 74 e $§ 16$, p. 80. 
Teríamos, deste modo, uma eversio consumada "pela metade"? Descartes não seria ingênuo a este ponto. Sem nada conceder ao crítico que pudesse fantasiosamente encontrar uma relação crepuscular com Aristóteles nesta passagem das Meditationes, a quarta meditação viria a expor com clareza o problema do erro. Lia-se ali que, muito embora o falsum aparecesse no iudicium, a relação entre ambos não transgredia esta manifestação. Afinal, havia uma larga distinção entre afirmar que o surgimento do erro consistia numa possibilidade encontrada no juízo (sendo ele a única forma da cogitatio a admitir a presença do defectus gerado pela privação) e que o juízo era propriamente o ser do erro. Não passava de mero reducionismo grego aquela suposição de convergência entre apresentar-se no juízo e ser por conta dele, sem uma explicação minuciosa . Aos olhos de Descartes, a verdadeira causa do "não ser certum" do erro repousava numa resposta muito menos simplista, que poderia situar seu aparecimento no juízo, é verdade, mas não sem antes conceber seu ser na conjunção de duas potências anímicas fundamentais e de natureza muito diversa:

"Enfim, aproximando-me mais propriamente de mim mesmo e investigando quais são meus erros (que denunciam alguma imperfeição em mim), percebo que dependem do concurso simultâneo de duas causas, a saber, da faculdade de conhecer que está em mim e da faculdade de escolher ou liberdade do arbitrio, isto é, do intelecto e simultaneamente da vontade". ${ }^{170}$

Assim sendo, a julgar pelas palavras de Descartes, a causa do erro encontrava-se, a bem dizer, numa simultaneidade de duas causas (...a duabus causis simul concurrentibus...). Nem somente do intelecto, nem somente da vontade: a possibilidade da compreensão do ser do erro jazia, na verdade, na apreensão daquele simul esse de tais faculdades.

Mas se era certo que o falsum dado no juízo resultava da simultaneidade da ocorrência do intellectus e da voluntas, restava ainda por esclarecer como ele emergia do encontro. E uma resposta só poderia ser ofertada à questão no momento em que o engenho meditativo - antes mesmo de explorar a relação parturiente do erro - nos conduzisse

\footnotetext{
170 "Deinde, ad me proprius accedens, et qualesnam sint errores mei (qui soli imperfectionem aliquam in me arguunt) investigans, adverto illos a duabus causis simul concurrentibus dependere, nempe a facultate cognoscendi quae in me est, et a facultate eligendi, sive ab arbitrii libertate, hoc est ab intellectu et simul a voluntate”. René Descartes, Meditationes, Med. IV, §9, p. 116. Cf. Martin Heidegger, Einführung in die phänomenologische Forschung, GA 17, §27b, p. 152: "A voluntas que é conjuntamente ao intellectus deve apresentar um tal ser que porta em si a possibilidade de um defectus". Sobre a reflexão cartesiana acerca do intelecto e da vontade, cf. Étienne Gilson, La liberté chez Descartes et la théologie, sobretudo parte II, capítulo II, p. 237-285.
} 
através da descrição destas faculdades. A começar pelo intelecto, Descartes ensinará que, por si só, mostrava-se ele incapaz de afirmar ou negar algo, restringindo-se à simples percepção de ideias que poderiam doravante formar juízos. E sobre a percepção destas mesmas ideias, já não se podia afirmar haver ali uma privatio no sentido do erro, pois o fato de desconhecer as ideias de muitas coisas que existem não condizia com a inserção do não-ser no ser (privação), mas significava apenas que o intelecto se encontrava delas apartado ou "apenas negativamente destituído" (negative tantum destitutus). Nenhum traço da falsitas e, ainda assim, a presença da imperfeição. Deus bem poderia ser um peritus artifex (artífice de perícia), dirá Descartes, mas parecia usar metros bem distintos para as suas criações, não colocando em cada uma de suas obras todas as perfeições postas em algumas delas:

"Se considero, por exemplo, a faculdade de entender, logo reconheço que aquela é demasiada exígua e muito finita em mim, a mesmo tempo que formo uma ideia muito maior de um outro qualquer, até mesmo máxima e infinita. E só porque posso formar sua ideia, percebo que ela pertence à natureza de Deus" ${ }^{\prime 171}$.

Quando o intelecto apreendia claramente a ideia de um Deus criador, tornava-se igualmente claro para ele sua pequenez e sua finitude em face à perfeição da onisciência e da onipotência divina. E conforme a investigação avançava neste sentido, parecia cada vez mais difícil não reconhecer quão cerceada era a generosidade do artesão e como as imperfeições se estendiam para além do próprio intelecto. Ora, bastava que se recordasse de certa passagem da primeira meditação para que fossem observados tais limites e se comprovasse a tese de que "não encontro completamente nenhuma [faculdade] que não entenda ser tênue e circunscrita em mim e imensa em Deus" (nullam [facultatem] plane invenio, quam non in me tenuem et circumscriptam, in Deo immensam, esse intelligam $)^{172}$. Ao tratar ali a questão da imaginação, Descartes ensinava que as ditas res imaginareae eram mais limitadas do que certamente se supunha. A sua formação não gozava de total liberdade criativa, surgindo como que de coisa alguma; na verdade, para que as imagines pudessem se formar, o imaginari deveria, por princípio, fundar-se em elementos da percepção. Quem imagina, por exemplo, um centauro e empenha-se mesmo

\footnotetext{
171 "Nam si, exempli causa, facultatem intelligendi considero, statim agnosco perexiguam illa et valde finitam in me esse, simulque alterius cuiusdam multo maioris, imo maximae atque infinitae, ideam formo, illamque ex hoc ipso quod eius ideam formare possim, ad Dei naturam pertinere percipio". René Descartes, Meditationes, Med. IV, §9, p. 116-118.

${ }^{172}$ Idem, Ibidem, Med. IV, §9, p. 118-120.
} 
em lhe dar formas das mais inusitadas sempre verá na base de seus esforços elementos que lhe foram atribuídos pela sensibilidade: parte equino e parte humano, esta composição fantasiosa terá origem em elementos outrora apreendidos pelo ato perceptivo. E caso o autor desta fantasia queira conduzí-la ao extremo, pensando em algo a tal ponto novo “(...) que nada do que antes se viu se lhe assemelhe e seja, assim, completamente fictício e falso, decerto que ao menos as cores de que se compõem devem ser, no entanto, verdadeiras" ([...] ut nihil omnino ei simile fuerit visum, atque ita plane fictitium fit et falsum, certe tamen ad minimum vere colores esse debent, ex quibus illud componant $)^{173}$. Não havia, portanto, atalhos que conduzissem à consumação de coisa puramente imaginária; quando "cartesianamente compreendida", a imaginação conservava limites, estando sempre agrilhoada à percepção em algum ponto. E se, por um lado, esta faculdade mostrava-se imperfeita porque seu território encontrava-se delimitado por linhas muito bem demarcadas, por outro, a faculdade imaginativa perfeita de Deus não conhecia restrições, sendo ela infinita - afinal, nada menos se poderia esperar de um creator onipotente; o imaginari divino - talvez dissesse algum fenomenólogo entusiasmado com comparações - poderia alcançar a pureza da apreensão do "não-mundo".

Isto quer dizer que ao homem não estaria reservado nenhum quinhão da perfeição que poderia ser encontrada na criação de Deus? Não exatamente, pois dentre as muitas faculdades imperfeitas, dadas no solo da finitude, a meditação encontrava uma que, "in se formaliter et praecise spectata" ("vista em si de modo formal e preciso"), não parecia ser menor no creatum do que efetivamente no creator. Num argumento danoso à própria eversio (ignorando-a por carregar demasiadamente em tintas teológicas), Descartes reconhecerá na voluntas ou libertas arbitrii (vontade ou liberdade do arbítrio) aquela faculdade da qual se via, enfim, emanar a generosidade divina. Era o que se declarava no cerne da quarta meditação:

"Mas não posso queixar-me de que não tenha recebido de Deus uma vontade ou liberdade de arbitrio suficientemente ampla e perfeita, pois certamente a experimento sem que esteja circunscrita por quaisquer limites (...) Somente da vontade ou da

${ }^{173}$ Idem, Ibidem, Med. I, §6, p. 25. Cf. Martin Heidegger, Einführung in die phänomenologische Forschung, GA 17, §27a, p. 147-151. 
liberdade de arbitrio, que experimento muito ampla em mim, não apreendo a ideia de outra maior $" 174$.

Era assim que, ao contrário de todas as faculdades, para a vontade tudo se passava como se ela não tivesse nenhum limite fixado para si. Sem nada que lhe estorvasse a amplitude sem par, ela figurava como a centelha divina no homem, uma espécie de perfeição no imperfeito que corroborava a tese teológica anunciada dogmaticamente, quer dizer, era por meio da vontade que se alinhavam a palavra do filósofo, arada a custo de longa meditação, àquela revelada pelo próprio Deus: "façamos o homem à nossa imagem e semelhança" (faciamus hominem ad imaginem et similitudinem nostram, Gênesis, 1: 26). E dizer que a semelhança entre criador e criatura residia na vontade já não significava como bem notará Heidegger - compreendê-la de acordo com a fórmula escolástica da indifferentia: que eu possa indiferentemente "fazer ou não fazer, isto é, afirmar ou negar, perseguir ou fugir" (vel facere vel non facere, hoc est affirmare vel negare, prosequi vel fugere), sem que alguma força externa me impulsione para qualquer uma destas possibilidades, não me autoriza - dirá Descartes - a situar aí o conceito de vontade; o fato de que nenhuma razão me impele, seja para lá quanto para cá, demonstra apenas um infimus gradus libertatis (ínfimo grau de liberdade). Na verdade, a perfeição da vontade não estará inclinada a um argumento de ordem tomista, mas sim a um argumento de ordem agostiniana. Antes que se pudesse dar razão à escolástica e conceder-lhe que uma absentia coactionis surgia como sinônimo da liberdade, a quarta meditação ensinava justamente o oposto, isto é, o conceito de voluntas ou arbitrii libertas já não residia na estagnação do "ou fazer ou não fazer", "mas, ao contrário, quanto mais propendo para uma delas - seja porque nela entendo o verdadeiro e o bom, seja porque Deus assim dispôs o íntimo de meu pensamento - tanto mais livremente a escolho" (sed contra quo magis in unam propendeo, sive quia rationem veri et boni in ea evidenter intelligo, sive quia Deus intima cogitationis meae ita disponit, tanto liberius illam elligo ${ }^{175}$. Só havia autenticidade no conceito de liberdade no momento em que se compreendia que suas

\footnotetext{
174“"Nec vero etiam queri possum, quod non satis amplam et perfectam voluntatem, sive arbitrii libertatem, a Deo acceperim; nam sane nullis illam limitibus circumscribi experior (...) Sola est voluntas sive arbitrii libertas, quam tantam in me experior, ut nullius maioris ideam apprehendam". Idem, Ibidem, Med. IV, §9, p. 116-118. Cf. Martin Heidegger, Einführung in die phänomenologische Forschung, GA 17, §27b, p. 153: "Que o homem seja livre, não é uma veritas naturalis, mas um dogma. Toda opinião que duvida da verdade é herética".

${ }^{175}$ Idem, Ibidem, Med. IV, §9, p. 120. Cf. Martin Heidegger, Einführung in die phänomenologische Forschung, GA 17, §27a, p. 151: "Quanto mais originária é a propensio ao bonum, tanto mais própria é a liberdade do agir". Cf. também: Étienne Gilson, Index scolastico-cartésien, p. 154-157.
} 
raízes estavam profundamente fincadas na determinatio, no ato de pender "ou para um ou para outro" - na medida em que este "um" ou este "outro" sejam sempre o bonum e o verum para o qual haja uma propensão da vontade. E esta inclinação ad bonum ocorrerá tão logo o intelecto nos oferte uma percepção clara e distinta para a qual possamos tender; é o intelecto, portanto, a dar à determinação da vontade seu perceptum ad prosequendum (percebido a ser perseguido) enquanto algo bom e verdadeiro.

Eis aí então não somente o reconhecimento fulcral do encontro das faculdades do intelecto e da vontade, mas também da marca fundamental do Ser daquele creatum à imagem e semelhança de seu perfeito creator: "quanto mais intimamente a vontade se atém ao apreendido de modo claro e distinto, tanto mais próprio é o homem naquilo que ele é. O apreender voluntário do clare et distincte perceptum é para Descartes a mais elevada possibilidade de ser do homem"176. Mas se para o homem não há nada que se sobreponha ao encontro das faculdades, nesta propensão da vontade ao bonum e verum dado pelo intelecto, como então pode surgir daí aquele error ou falsum expresso pelo juízo? O erro surge daquela discrepância de natureza das faculdades no momento de sua conjunção. Pois quando o intelecto finito (cujo princípio reside no fato de não poder entender muitas coisas) encontra-se com aquela vontade perfeita e ilimitada, é possível que aí um defectus tome seu lugar, quer dizer, uma vez que a vontade manifesta-se de maneira muitíssimo mais ampla do que o intelecto, ela poderá se alastrar à determinadas coisas que ele simplesmente não compreende - e por não haver sobre ela uma percepção clara e distinta para a qual se possa propender, "facilmente [a vontade] desvia-se do verdadeiro e do bom, e deste modo erro e peco" (facile a vero et bono deflectit [voluntas], atque ita fallor et pecco). E se é assim, no momento em que minha vontade - dirá Descartes - extrapola aquilo que o intelecto pode lhe oferecer como bem discernido, fazse claro que "é neste uso não-reto da liberdade do arbítrio que reside aquela privação que constitui a forma do erro" (in hoc liberi arbitrii non rectu usu privatio illa inest quae formam erroris constituit) ${ }^{177}$. Mas se esta vontade, signo da semelhança na criação, aparecia como o primeiro passo em direção ao erro por conta de seu excesso, não seria razoável àquele que meditava rever os passos de uma tese que eximia Deus de ser a causa do mal? Ora, esta mera suposição sacrílega era impensável, pois entrava em embate e comprometia a ideia já clara e distinta - exposta na terceira meditação - de que Deus é o

\footnotetext{
${ }^{176}$ Martin Heidegger, Ibidem, GA 17, §27b, p. 157.

${ }^{177}$ René Descartes, Meditationes, Med. IV, §10, p. 120 e $\$ 13$, p. 124.
} 
summum bonum (sumo bem) a quem repugnat esse fallacem (repugna ser enganador). Além disso, esta vontade em si "é amplíssima e perfeita em seu gênero" (est enim amplissima, atque in suo genere perfecta $)^{178}$; entendê-la como imperfeita seria produzir um contra-senso, uma vez que esta faculdade é em mim tal e qual é no criador. Reconhecida a natureza de Deus, nada me permite - afirmará Descartes em consonância com a Suma Teológica - entendê-lo como causa de qualquer mal ou imperfeição: se, por exemplo, eu manco, mas ainda assim consigo me mover, é graças à virtude motora que, advinda do próprio Deus, faz do movimento algo perfeito; já a causa do claudicar encontra-se numa imperfeição que não provém "da virtude motora, mas da curvatura da perna" (ex virtute motiva, sed ex curvitate cruris) ${ }^{179}$, isto é, de uma deficiência do homem devido à sua finitude. E assim também será com o erro. As Meditationes não acusam nem Deus em sua perfeição, nem a vontade igualmente perfeita que herdo enquanto creatum: a causa dum erro que nasce no encontro das faculdades sou eu e nada além de mim, reconhecerá Descartes. Afinal, se a vontade excede, por definição, os limites do intelecto e volta-se, por isso, à parte falsa, é porque eu falho em antecipar uma percepção clara e distinta à sua propensão; o falsum que então se manifesta no juízo lá está não somente em razão de minha abstenção em perscrutar a coisa, mas também porque minha vontade se lança ao que ainda permanece obnubilado. O erro é, portanto, fruto de minha imperfeição, do mau uso que faço de minha liberdade ao julgar de maneira imprudente sobre aquilo que não entendo retamente.

Mas se este reconhecimento do ser do erro soava um tanto quanto fatídico por encontrar no homem sua causa, ele não deixava de apresentar também uma sutil consolação. A investigação do falsum revelava não apenas a sua origem no simul esse da vontade e do intelecto, mas mostrava também como evitá-lo:

"E, seguramente, não pode haver nenhuma outra causa do erro senão a que expliquei. Pois, se toda vez que julgar, eu contiver minha vontade [dentro dos limites do meu conhecimento], a fim de que ela se estenda somente às coisas que o intelecto mostre clara e distintamente, é de todo impossível que eu erre, porque toda percepção clara e distinta é sem dúvida algo [de real e de positivo](...) ${ }^{, 180}$.

\footnotetext{
${ }^{178}$ Idem, Ibidem, Med. IV, §10, p. 120.

${ }^{179}$ São Tomás de Aquino, Summa Theologica, q. XLIX, art. II, 3. Martin Heidegger, Ibidem, GA 17, §28, p. 160.

${ }^{180 "}$ Et sane nulla alia esse potest ab ea quam explicui; nam quoties voluntatem in iudiciis ferendis ita contineo [dans le bornes de ma connaissance], ut ad ea tantum se extendat quae illi clare et distincte ab
} 
Lição preciosa esta que vinha à luz no final da quarta meditação - afinal, era por meio dela que se ensinava a conter a desmesura de uma vontade amplíssima, não conduzindo sua determinação para nada além daquilo que o intelecto assegurava clara e distintamente. Tratava-se, assim, de uma reflexão que propunha corrigir aquela imperfeição perturbadora que colocava o homem junto ao malum; sustentava-se com ela a pretensão de recuperar aquela maxima et praecipua perfectio (máxima e principal perfeição) que nele jazia em alguma medida graças à semelhança com Deus. E para tanto, não bastava que a equivalência da amplitude das faculdades da vontade e do intelecto se apresentasse de maneira esporádica, mas se carecia de adquirir "habitum quemdam non errandi" ("um certo hábito de não errar") ${ }^{181}$, uma justa forma de obstar o falsum e operar somente com o verum. "O ser do homem deve tornar-se inequívoco (irrtumlos)" "182 - e Descartes entenderá não haver outro modo de impedir a presença do erro e de tangenciar a perfeição senão por obra e graça de uma regulação determinada. Regulae estabelecidas para oferecer uma direção ao engenho: apenas com sua observância extirpava-se o perigo do falsum e preservava-se o conhecimento no terreno da veritas. Com elas, "pela primeira vez e de modo evidente vem à expressão o caráter de preocupação do conhecer" ${ }^{183}$.

Ao passo que o homem entendia repousar em seu Ser aquela infausta possibilidade do errare, surgia-lhe uma preocupação em assegurar o próprio conhecimento enquanto verdade, para que coisa alguma - seja ela uma consueta opinio (opinião costumeira), ali presente pela familiaridade e longo uso, seja uma mera desídia no ato de investigar - lhe arrastasse na direção do mal e lhe eivasse o traço de perfeição. Tratava-se, assim, de uma preocupação que exigia do homem que "obtivesse seu próprio Ser" tão logo "o Ser do conhecer se consumasse ao evitar o erro" ${ }^{184}$. E era nesta necessidade cartesiana de furtarse ao erro que as Regulae encontrariam o seu direito de cidadania na filosofia: elas eram o crivo, o critério de como a verdade deveria ser encontrada, a fim de que houvesse precisa concordância entre o intelecto e a vontade; no jargão heideggeriano, elas nada mais eram do que o colocar junto àquele caminho ( $\left(\dot{\eta} \mu \mu^{\prime} \theta 0 \delta\right.$ os) que deveria ser trilhado nesta determinação do conhecimento ${ }^{185}$. Mas se esta era a função fundamental a ser

intellectu exhibentur, fieri plane non potest ut errem, quia omnis clara et distincta perceptio proculdubio est aliquid [de réel et de positif] (...)”. René Descartes, Meditationes, Med. IV, §16, p. 128.

${ }^{181}$ Idem, Ibidem, Med. IV, §15, p.128.

${ }^{182}$ Martin Heidegger, Einführung in die phänomenologische Forschung, GA 17, §34, p. 196.

${ }^{183}$ Idem, Ibidem, GA 17, §34, p. 196.

${ }^{184}$ Idem, Ibidem, GA 17, §35, 202.

${ }^{185}$ Descartes escrevia no limiar da Regula IV: "Necessaria est methodus ad rerum veritatem investigandam". De maneira muito particular, mas sempre fiel à etimologia dos termos, Heidegger 
desempenhada pelas Regulae, como elas a levavam a termo? De que modo perguntaríamos a Descartes - elas nos permitiam ensaiar os primeiros passos neste caminho? Ele certamente nos responderia: para que o conhecimento possa ser assim denominado, preservando a dignidade do nome que carrega, deve ele ser colocado sob o auspício do mandamento da clara et distincta perceptio ${ }^{186}$. E antes que pudéssemos ainda uma outra vez indagar a Descartes acerca do sentido desta complexa determinação da regula generalis, os Principia Philosophiae se antecipariam em apresentar uma descrição de seus elementos. Era ali que se reconhecia, antes de tudo, que a definição da regra dependia da significação atribuída à noção de perceptio. Uma perceptio que, no seio da filosofia cartesiana, era menos similar àquela percepção kantiana, atrofiada e limitada à

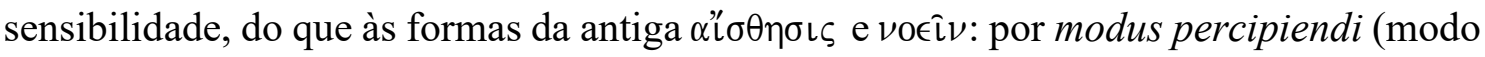
de perceber) entendiam-se o "sentir, imaginar e entender puramente" (sentire, imaginari et pure intelligere), ou seja, todo apreender de algo em si mesmo ${ }^{187}$.

Todavia, a receita de Descartes não se detinha simplesmente na definição da perceptio, mas exigia também que ela fosse necessariamente clara. O que era então aquela claritas à qual ela se encontrava atrelada? Conforme a interpretação heideggeriana, a clareza da percepção não será senão o apreender o ente em si mesmo, tal qual é e tal qual deve ser. Enquanto um perceptum (percebido), este ente será tomado como uma res aperta, isto é, não padecerá de nenhum ocultamento em sua apreensão, doando-se diretamente para o conhecimento. Daí ser a claritas entendida como uma abertura para o que "não está de modo algum velado", mas que deverá estar sempre ai (daliegend, daseiend) como praesens - como presente e aberto "que tem a possibilidade de satis fortiter movere o apreender para ele direcionado" ${ }^{188}$. Esta claritas, contudo, não se deixara ver desacompanhada; Descartes jamais se referiu a esta "percepção" em sentido amplo como clara perceptio. A perceptio sempre fora clara et distincta. Se este é então o caso, como compreender esta "distinção" que a ela se associa? Ora, a essência da distinctio é a marca de atestação da própria clareza, é o que a torna precisa diante das

traduziria a passagem da seguinte maneira: "Necessário (essencialmente necessário) é o método para descobrir as pegadas da verdade (certitude) do ente e para seguí-las". Cf. Ernildo Stein, A questão do método na filosofia: um estudo do modelo heideggeriano, p. 20.

186 "A regra sob a qual Descartes coloca o conhecer é a clara et distincta perceptio". Martin Heidegger, Einführung in die phänomenologische Forschung, GA 17, §35, p. 203.

${ }^{187}$ René Descartes, Principia Philosophiae, pars prima, §32, p. 17. Martin Heidegger, Ibidem, GA 17, §35, p. 203: "Descartes emprega perceptio de muitas maneiras com a mesma significação, como apprehendo, deprehendo, animadverto: perceber (vernehmen) algo em si mesmo".

188 Idem, Ibidem, GA 17, §35, p. 204. 
demais perceptiones; distinguere significa assegurar a clareza de uma determinada perceptio, a fim de que ela não se confunda com nenhuma outra. "O distinctum é o momento específico da limitação correspondentemente clara do claro mesmo" 189 - o que significa certamente dizer que é possível ao homem experimentar clarae perceptiones (claras percepções) sem que sejam distinctae (distintas), mas nunca o contrário. E era esta relação que os Principia Philosophiae se propunham explicar. Descartes escrevia: se eu sinto uma dor que me percorre o corpo e sei que ela está ali, fazendo-se presente como res aperta, significa que eu a apreendo em absoluta clareza; no entanto, tê-la de modo tão claro ainda não lhe confere nenhuma distinção, uma vez que esta dor experimentada pode ser submetida a um juízo obscuro e expressar uma confusão: a dor notada tão claramente não é de modo algum distinta porque, ao pungir o corpo, não sei se ela se origina na corrosão de um dente ou no rasgar do músculo de uma perna. O mesmo ocorreria, por exemplo, com um soldado que, retornando do combate, sentia claramente a dor que lhe era infligida nas costas, mas não sabia distinguir se sua causa era a fivela deslocada sob a couraça ou um ferimento provocado pelo inimigo:

“Assim, quando alguém sente uma grande dor, nele é claríssima esta percepção da dor, embora não seja sempre distinta (...) E, deste modo, a percepção pode ser clara, ainda que não seja distinta; no entanto, nenhuma percepção pode ser distinta, a menos que seja clara" ${ }^{190}$.

Que a percepção fosse dita clara e distinta, significava que deveria sê-lo exatamente nesta ordem. Era necessário respeitar a disposição dos fatores: a clareza precede a distinção e a funda; pode muito bem haver clareza sem distinção, mas é impossível que haja distinção sem clareza. E para que a regra se cumpra e cumpra também seu dever com a preocupação com o conhecimento, é necessário que ambos os predicados lá estejam, respectivamente. A regra da clara et distincta perceptio assim se delineava: inicialmente, apreender o ente em si mesmo, tal qual é, sem excessos ou faltas; em seguida, circunscrevê-lo à sua própria clareza, a fim de que não se confunda com percepções doutros entes.

\footnotetext{
${ }^{189}$ Idem, Ibidem, GA 17, §35, p. 205.

190 "Ita, dum quis magnum aliquem sentit dolorem, clarissima quidem in eo est ista perceptio doloris, sed non semper est distincta (...) Atque, ita potest esse clara perceptio, quae non sit distincta; non autem ulla distincta, nisi sit clara". René Descartes, Principia Philosophiae, pars prima, §46, p. 22; pars quarta, §197, p. 320-321. Cf. Gérard Lebrun, A noção de "semelhança” de Descartes a Leibniz, in: A Filosofia e sua história, p. 435-436.
} 
Mas se assim se definia aquela regra fundamental da clara et distincta perceptio, ela não poderia apontar para outro desfecho senão o estabelecimento do ato de conhecer enquanto conhecimento científico. E a razão para isto era facilmente identificável: quando perguntávamos “o que é uma ciência?”, Descartes nos ensinava por meio da segunda de suas Regulae que "omnis scientia est cognitio certa et evidens" ("toda ciência é um saber certo e evidente") ${ }^{191}$, quer dizer, o pensamento que tergiversava a todo probabilis (provável) e tomava para si apenas as coisas dadas claramente e muito bem discernidas. O "fazer ciência" nada mais era do que a boa aplicação da regula generalis. Disto e nada mais, pois uma autêntica preocupação com o conhecimento já não atribui nenhum louvor à atitude daqueles doutos que, não obstante versem em dificílimas matérias, não são capazes de distinguir o verdadeiro do falso (vera a falsis distinguere non valentes) e ainda nos coagem a admitir, dada sua autoridade, coisas dúbias como certas - coisas acerca das quais "não tão grande é a esperança de elevar a doutrina, quanto é o perigo de diminuíla" (non tanta sit spes augendi doctrinam, quantum est periculum minuendi) ${ }^{192}$. Ora, vem daí aquela desconfiança cartesiana e a necessidade de seu isolamento em relação à história do pensamento filosófico. Pois como frequentar um passado que não passa de um campo de embate de ideias obscuras e prejudiciais, onde a verdade está ausente porque os homens insistem em sobrepor noções dogmáticas às ideias claras e distintas? Aos olhos de Descartes, não havia valor algum em retermos na memória uma infinidade de demonstrações, passagens de obras e seus conceitos se não fossemos capazes de resolver as questões por meio da aptidão de nosso engenho; seríamos sufocados por opiniões controversas caso desperdiçássemos nosso tempo em pesar argumentos antigos ao invés de darmos ouvidos à razão, ao lumen naturale. Da mesma maneira que não seríamos nós mesmos matemáticos simplesmente por conhecer a doutrina de outros matemáticos, não seremos filósofos apenas porque, em algum momento, lemos "todos os argumentos de Platão e Aristóteles" (omnia Platonis et Aristotelis argumenta). No melhor dos casos, não seríamos nada além de historiadores: "não pareceríamos, com efeito, ter aprendido ciências, mas histórias" (ita enim, non scientias videremur didicisse, sed historias) ${ }^{193}$. O filósofo ou cientista imerso na preocupação com o conhecimento, confessará Descartes

\footnotetext{
${ }^{191}$ René Descartes, Regulae ad directionem ingenii, Regula II, p. 6.

${ }^{192}$ Idem, Ibidem, Regula II, p. 6. Cf. Martin Heidegger, Einführung in die phänomenologische Forschung, GA 17, §36, p. 207: "Em consideração à esta ideia de ciência, servimo-nos da regra a partir dela mesma, cujo auxílio nos porta à própria altivez da existência científica e humana".

${ }_{193}$ Idem, Ibidem, Regula III, p. 16. Cf. Jean-Luc Marion, Sobre a ontologia cinzenta de Descartes, §6, p.6166.
} 
em suas Cogitationes Privatae, compreenderá que pode e deve progredir "non lecto auctore" ("sem ler qualquer autor"), deixando de atuar como herdeiro da nefas de seus predecessores na medida em que se serve da regula generalis do método. Neste sentido, obter rigorosamente uma ciência exigirá que o pensador "se gere sem pai" (como bem disse Jean-Luc Marion), que dependa apenas de si mesmo, do exercício e da capacidade de sua razão de tomar as coisas clara e distintamente - e que a ciência que resulte deste proceder seja "assim como uma mulher: se permanece pudica junto ao homem, é cultivada; caso se faça comum, torna-se vil" (velut mulier: quae, se pudica apud virum maneat, colitur; si communis fiat, vilescit) ${ }^{194}$.

Uma vez excluído terminantemente aquele referencial infame da história da filosofia, de que maneira a preocupação com o conhecimento operava na pretensão de obter suas percepções claras e distintas, fundadoras de uma ciência absoluta? Quais eram os elementos que permitiam bem conduzir a meditação? Para que a cognitio se apresentasse sempre como certa et evidens, não contendo nenhuma fissura pela qual o erro pudesse penetrar no âmbito científico, contava-se com dois momentos fundamentais: o intuitus e a deductio. Sobre o intuitus, a terceira das Regulae afirmará ser ele "o conceito tão fácil e distinto da mente pura e atenta" (mentis purae et attentae tam facile distinctumque conceptum) que, uma vez "nascido somente da luz da razão" (nascitur a sola rationis luce) e independente de qualquer método determinado para ser aquilo que é, não permitirá “absolutamente nenhuma dúvida” (nulla prorsus dubitatio) naquilo que entendemos ${ }^{195}$; ele é um sinônimo para o conceito de experientia - mas não para aquela experiência no sentido empírico (que os gregos batizaram de '́f $\mu \epsilon \iota \iota^{\prime} \alpha$ ) e sim para o $\epsilon \pi \alpha ́ \gamma \omega$, o ato de dirigir-se diretamente a algo, de apreendê-lo claramente e sem entremeios. Sendo a expressão latina da €́ $\pi \alpha \gamma \omega \gamma \eta ́$ aristotélica, o intuitus de Descartes (não sem ironia, já que há pouco se confessara as razões da aversão à história da filosofia) compartilhará de seus atributos: esboçando-se como um tímido percursor da intuição categorial fenomenológica, "todo intuitus, segundo seu próprio ser enquanto ser-conhecendo, é visto como judicare”, isto é, não como um juízo em si mesmo, mas algo como um juízo ${ }^{196}$

\footnotetext{
${ }^{194}$ René Descartes, Cogitationes Privatae, p. 190.

${ }^{195}$ Idem, Ibidem, Regula III, p. 16-17. Cf. Jean-Luc Marion, Op. cit., §7, p. 66-74.

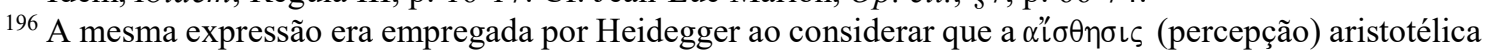

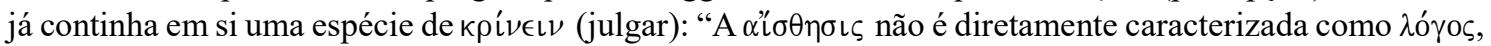

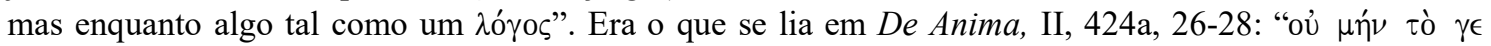

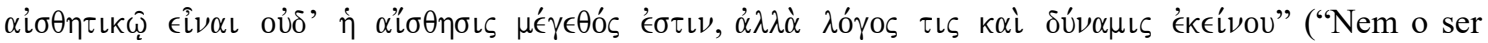
perceptível, nem a percepção são uma grandeza, mas um certo juízo e sua potência"). Cf. Martin Heidegger, Einführung in die phänomenologische Forschung, GA 17, §2c e Ergänzung 3 e 4, p. 25-30 e 294-295.
} 
cujo objeto será sempre "o apreendido no apreender simples enquanto tal", o verdadeiro "fundamentum previamente dado para todo juízo"197.

Mas que objetos eram estes que carregavam o título de fundamentum e aos quais o intuitus como "modo de conhecer" (Erkenntnisart) bastava para sua manifestação? Mais uma vez as Regulae conteriam a resposta à questão. Era ali que Descartes viria a reconhecer que a aritmética e a geometria "existem de modo muito mais certo do que outras disciplinas" (caeteris disciplinis longe certiores existant). E o motivo pelo qual elas mereciam ser rememoradas com tamanha lisonja encontrava-se muito menos no procedimento do cálculo por elas utilizado do que numa razão mais originária: sua determinação com ciência rigorosa enraizava-se profundamente no fato que "somente elas tratam do objeto puro e simples" (hae solae circa objectum ita purum et simplex versantur $)^{198}$, quer dizer, tanto aritmética quanto geometria incidiam - por meio do intuitus - sobre os princípios fundamentais, sempre muito puros porque dados diretamente na simplicidade de seu ser. Então, aos olhos de Descartes, não havia disciplina que conservasse a regra com maior fidelidade do que as matemáticas, visto que, à distinção de toda outra parte, eram elas o local onde o apreendido se dava tal qual é, numa apreensão simplíssima: “dentre as ciências já conhecidas, somente a aritmética e a geometria permanecem como aquelas para as quais a observação desta regra nos reconduz" ([...] solae supersint Arithmetica et Geometria ex scientiis iam inventiis, ad quas huius regulae observatio nos reducat $)^{199}$. Todavia, isto não significava afirmar que toda sua clareza se restringia apenas ao intuitus. Se este fosse o caso, os Elementa de

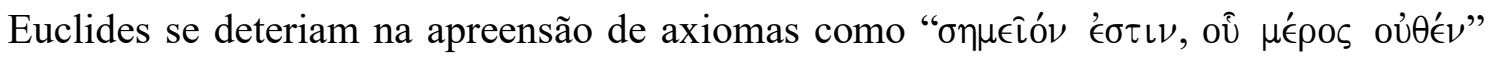

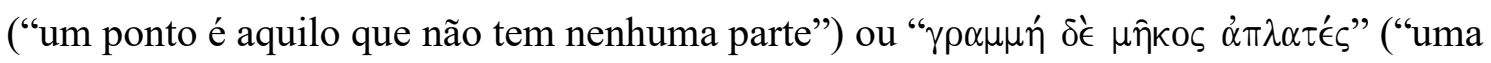
reta é um comprimento sem largura"). No entanto, como bem se sabe, a obra se desdobrava longamente e avançava em questões que deixavam o campo das coisas puras e simples em sentido às coisas "compositae et complexae" - como, por exemplo, " $\alpha$ mó

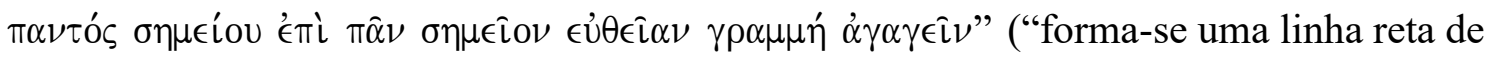
qualquer ponto até qualquer ponto") ${ }^{200}$. Se é assim, era possível às matemáticas progredir a partir daquele fundamentum intuído e certo para algo menos simples, é verdade, ainda que não menos certo. Havia ali uma maneira de tramitar do simples ao complexo sem

\footnotetext{
${ }^{197}$ Martin Heidegger, Ibidem, GA17, §36, p. 208.

${ }^{198}$ René Descartes, Regulae, Regula II, p. 12.

${ }^{199}$ Idem, Ibidem, Regula II, p. 8.

${ }^{200}$ Euclides, Elementa, öpo e $\alpha i \tau \eta ́ n \alpha \tau \alpha$, p. 6-7.
} 
incorrer em erro, de conceder à certeza um prolongamento que só poderia ser operado pela deductio. E como era descrito este segundo momento fulcral da composição do saber científico? Ora, quando a Regula $I V$ tomava para si a tarefa de desvelar a essência da deductio, ela principiava por uma confissão de Descartes: "não sei o que de divino" (nescio quid divini) - dizia ele - emana das matemáticas e permite-nos colher "frutos nascidos dos princípios inatos deste método" (fruges ex ingenitis huis methodi principiis natae); parecia haver em seu domínio algo imbuído no deífico, um certo véu de sacralidade que Platão já pressentira ao impedir o acesso à academia àquele futuro

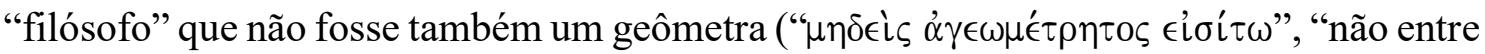
o ignorante em geometria!”): “quando em seguida pensei por qual razão os primeiros filósofos de outrora não queriam admitir nenhum imperito da mathesis no estudo da sapiência (...) suspeitei que eles reconheciam uma certa mathesis muito diversa desta vulgar de nossa era" (cum vero postea cogitarem, unde ergo fieret, ut primi olim Philosophiae inventores neminem Matheseos imperitum ad studium sapientiae vellent admittere [...] plane suspicatus sum, quamdam eos Matheseos agnovisse valde diversam a vulgari nostrae aetatis $)^{201}$. E o que vinha a ser este "algo divino"? Tratava-se do elemento que perpassava as matemáticas como método, dum ordo que lhes fornecia o solo estável e rigoroso da cientificidade ao ensiná-las que as ideias deveriam ser dispostas de tal modo que cada uma delas fosse precedida de todas as outras de que dependiam, e que precedessem aquelas que se mostravam suas dependentes - isto é, sempre transitando das certezas simplicissimae et facillimae em sentido às complexae et compositae, conquistando primeiramente as res absolutae em sua clareza e evidência para, em seguida, apreender as res relativae. O ordo é a dedução e a dedução, como acrescentará Heidegger, "é o caminho pelo qual a totalidade dos objetos de uma região científica é apreendida. A ideia de método encerra em si a ideia de series. Para a preparação metódica, a ideia de série é o fio condutor, pois se procede dos objetos mais simples para os compostos" 202 .

Se Descartes recorria ao exemplo privilegiado das matemáticas na constituição do método, seríamos então obrigados a assumir que as ciências só cumpririam seu desígnio mediante sua absoluta matematização? Esta seria uma má leitura, e levá-la adiante seria cometer uma profunda injustiça com o texto das Regulae. Verdade seja dita, Descartes

\footnotetext{
${ }^{201}$ René Descartes, Regulae, Regula IV, p. 28-30.

${ }^{202}$ Martin Heidegger, Einführung in die phänomenologische Forschung, GA 17, §36, p. 217. Cf. Jean-Luc Marion, Sobre a ontologia cinzenta de Descartes, §8 e \$27, p. 74-77 e 225-235.
} 
jamais vaticinou a construção de um império matemático, tendo como súditas todas as ciências. $\mathrm{O}$ que se proferia era algo muito diverso:

"Mas é necessário concluir a partir disso tudo que não somente a aritmética e a geometria devem ser aprendidas, mas sim que aqueles que procuram o reto caminho da verdade não devem se ocupar de nenhum objeto acerca do qual não possam conceber uma certeza igual às demonstrações aritméticas e geométricas "203.

Nada nestas linhas nos permite afirmar que o método consiste numa redução e subordinação de todos os saberes às matemáticas. $\mathrm{Na}$ verdade, elas nos convidam a ter muito clara a ideia de que a busca por uma "certeza igual às demonstrações aritméticas e geométricas" é coisa muito distinta da ideia de ser "igual à certeza destas mesmas demonstrações": não se trata dum desenfreado matematizar das disciplinas, mas antes da apreensão do método que as matemáticas souberam empregar melhor do que qualquer outra ciência. Afinal, a regra está longe de ser sua especificidade; regra é regula generalis, uma mathesis universalis que lá deveria estar em favor da scientia em geral, dela fazendo um saber certo e evidente - tal como outrora escrevera Eustáquio de São Paulo (donde as Regulae herdam sua definição de cientificidade) ${ }^{204}$. O lance filosófico inovador de Descartes não estava, portanto, em transformar as matemáticas no método, metendo-as forçosamente em réstia de filósofo, mas em compreender que o método era por elas empregado e que poderia estender-se à toda e qualquer ciência, conduzindo-a pelo caminho cujo horizonte era aquele da certitudo. Esta era a preciosa lição que nos ofertava a Regula II: deve-se entender o profundo significado do cernere e, com isto, lidar unicamente com aquilo que fazia da ciência uma ciência, o certum; todo saber que viesse a se intitular como científico deveria operar, enquanto tal, com o método e fincar firmemente suas raízes na certeza.

Havia, então, um propósito subjacente a todos estes volteios realizados em aspectos metódicos. E qual seria ele? Ora, o que ali se revelava - escreverá Heidegger não era nada menos do que o "estrito caroço" (para nos servirmos de uma expressão de Guimarães Rosa) da questão cartesiana: a preocupação do conhecer (Sorge des

\footnotetext{
203 "Iam vero ex his omnibus est concludendum, non quidem solas Arithmeticam et Geometriam esse addiscendas, sed tantummodo rectum veritatis iter quaerentes circa nullum objectum debere occupari, de quo non possint habere certitudinem Arithmeticis et Geometricis demonstrationibus aequalem". René Descartes, Regulae, Regula II, p. 12.

204 “... nonnunquam scientia apellatur omnis certa ac evidens notitia...”. Eustáquio de São Paulo, Summa Philosophica, I, p. 231. Ct. Étienne Gilson, Index scolastico-cartésien, p. 262.
} 
Erkennens), bem como a ideia de ciência absoluta que dela se desentranhava, somente poderiam se consumar ao passo que estabelecessem sua "morada" na preocupação da certeza (Sorge der Gewißheit). “Assim, a morada da preocupação do conhecer enquanto preocupação da certeza é uma morada completamente característica (...) Dito de modo sucinto, a morada da preocupação junto à determinadas ciências, neste respeito completamente determinado, mostra que o esse enquanto verum e verum enquanto certum é colocado primeiramente na preocupação, assim que o ens somente chega à sua tarefa num desvio em direção ao certo" ${ }^{205}$. Isto quer dizer que, para Descartes, o verum só poderia ser (numa decisão arbitrária, é preciso reconhecer) o verum qua certum (o verdadeiro enquanto certo), e que aquela determinação do ser do conhecer, alcançada pela meditatio quarta como uma propensio ad bonum enquanto propensio ad verum tomava, em última instância, o contorno de uma propensio ad certum. Daí que, sob a regência das Regulae, a preocupação com o conhecer imiscuía-se na preocupação com a certeza e passava a exigir para sua ciência nascente nada menos que o objeto perfeitamente discernido e assegurado: uma vez guiado pelo fio de Ariadne do Método, aquilo pelo que se procurava (das Gesuchte) deveria ser, antes de tudo, aliquid certum (algo certo) e que pudesse se comportar como um fundamentum inconcussum (fundamento inabalável), donde se desdobraria todo conhecimento subsequente. Inicialmente - lia-se no princípio da segunda das Meditationes - pouco importava o que (was) viria a ser este buscado ou se apresentava uma determinação positiva ou negativa; a única "preocupação" consistia em que pudesse ser conhecido em sua certeza: "e prosseguirei até conhecer algo certo, ou, na falta de outra coisa, que pelo menos reconheça como certo que nada há que seja certo" (pergamque porro donec aliquid certi, vel, si nihil aliud, saltem hoc ipsum pro certo, nihil esse certi, cognoscam) ${ }^{206}$. Mas a fim de que este procurado pudesse ser encontrado, era necessário pôr em curso o próprio Suchen. E como Descartes daria início a tal "procurar" pelo fundamento? A resposta é bastante conhecida. O caminho percorrido na busca pelo certum que deve ser encontrado delineava-se, a princípio, como um movimento de negação de indumentária hiperbólica:

"Suponho, portanto, falsas todas as coisas que vejo: creio que nunca existiu nada do que a memória mendaz representa; simplesmente não tenho nenhum dos sentidos,

\footnotetext{
${ }^{205}$ Martin Heidegger, Einführung in die phänomenologische Forschung, GA 17, §37, p. 221-222. Cf. JeanLuc Marion, Sobre a ontologia cinzenta de Descartes, §4, p.51: "Aquilo que não se pode conhecer na modalidade da certeza não é certamente para conhecer, dado que conhecimento e certeza se confundem". ${ }^{206}$ René Descartes, Meditationes, Med. II, §1, p.42.
} 
corpo, figura, extensão, movimento e lugar são quimeras. O que será, pois, verdadeiro? Talvez isto somente: nada é certo". ${ }^{207}$.

Uma vez que a possibilidade do erro se mostrava tão real e tão presente, a ponto de colocar em risco o primado da certeza, Descartes compreendia que somente um posicionamento radical em face do conhecimento evitaria imprimir-lhe tal mácula. Uma pretendida radicalidade que não se cumpria senão naquele nihil esse certi, isto é, num dubitare (duvidar) cuja essência consistia em reunir a totalidade dos saberes, apreendê-la numa só visada (continere) e, ao final, apartá-la (abstinere) de toda e qualquer consideração acerca do conhecimento. A estratégia cartesiana estava então em promover uma remotio - ou como a Heidegger aprazia traduzir, um "não-deixar-vir-à-questão" (Nicht-in-Fragekommen-lassen), ao impedir qualquer conhecimento de vigorar previamente porque ali a única certeza era a possibilidade do erro. Neste sentido, tudo se encontrava sob a sombra de uma suppositio falsi: uma suposição que não fazia concessões, que não era piedosa ou abria exceções, pois, a fim de encontrar aquilo que pudesse lhe opor resistência e atender às imposições das regras do método, tudo marcava com o signo da incerteza. "A possibilidade desta orientação - escreverá Heidegger - deixa-se também mostrar de modo completamente esquemático: que o incertum, o qual é para Descartes o objeto da dubitatio, nada mais é do que o non verum, se o certum é o verum. Como non verum, o incertum já é em si falsum, enquanto falsum é non ens" ${ }^{208}$. Assim sendo, se nada é reconhecido como certo e, consequentemente, não existe, o "caminho da dúvida" (Zweifelsweg) coloca a preocupação com o conhecer numa Endsituation, uma "situação limite" que tendia ad absurdum e conduzia a regula generalis ao extremo de si mesma, fixando-a no solo dum radical filosofar: quando o ato de duvidar se alastrava graças à "suposição do falso" na totalidade das coisas, a busca pelo fundamentum enquanto principium dará seu primeiro passo neste "caminho" com a eversio generalis de todas as opiniões correntemente aceitas daquilo que se supõe conhecer.

Mas como seria possível estender esta suposição à determinadas situações e julgálas como meras opiniões, colocando-as em dificuldade quanto à certeza na qual se

\footnotetext{
207 "Suppono igitur omnia quae video falsa esse; credo nihil unquam extitisse eorum quae mendax memoria repraesentat; nullos plane habeo sensus; corpus, figura, extensio, motus, locusque sunt chimerae. Quid igitur erit verum? Fortassis hoc unum, nihil esse certi”. Idem, Meditationes, Med. II., §3, p. 42.

${ }^{208}$ Martin Heidegger, Einführung in die phänomenologische Forschung, GA 17, §40, p. 231-232.
} 
apresentavam? Era exatamente sobre esta questão que Descartes refletia no início da primeira de suas Meditationes:

"Mas ainda que os sentidos nos enganem às vezes acerca de certas coisas miúdas e mais remotas, talvez haja, no entanto, muitas outras coisas sobre as quais não se pode duvidar de modo algum, não obstante hauridas dos sentidos: que agora estou aqui, sentado junto ao fogo, vestindo esta roupa de inverno, tendo este papel às mãos e coisas semelhantes $" 209$.

Que eu esteja aqui, com minhas vestes hiemais, diante desta folha sobre a qual deixo meus apontamentos filosóficos, são percepções que, de tão imediatas e aparentemente certas, tornam sua negação dificílima. Afinal, como negar a presença de meu corpo ou destas mãos cujos movimentos imprimem caracteres sobre o papel branco? E caso o fizéssemos, em que diferiríamos dos loucos que, tendo o cérebro afetado pelo "vapor da negra bílis" (vapor ex atra bile), supõem sua própria realeza ou pensam trajar a púrpura cardinalícia quando, na verdade, são paupérrimos e perambulam nus? Por certo, dirá Descartes num primeiro momento, não passaríamos de insanos caso negássemos coisa tão habitual quanto a situação do corpo: "mas eles são dementes e eu não pareceria menos demente se neles buscasse um exemplo para mim" (sed amentes sunt isti, nec minus ipse demens viderer, si quod ab iis exemplum ad me transferrem) ${ }^{210}$. O argumento é aparentemente forte, apresentado numa afirmação imponente, supostamente incontestável por aqueles que pretendem fazer bom uso da razão... e que não resistirá ao passo subsequente da meditação. E isto porque a evidência que tenho de meu corpo e de sua relação com o "mundo circundante" (Umwelt) pode muito bem ter um fundamento onírico: "quão frequentemente - escreverá Descartes - a quietude noturna persuade destas coisas usuais, isto é, que estou aqui, vestindo esta roupa, sentado junto ao fogo, quando, porém, estou deitado entre cobertas e com as vestes depostas!" (quam frequenter vero usitata ista, me hic esse, toga vestiri, foco assidere, quies nocturna persuadet, cum tamen positis vestibus iaceo inter strata! $)^{211}$. Se já não sou capaz de distinguir com evidência aquilo que me é dado pela apreensão sensível ou pelo sonho ludibriante, vago no terreno de coisas incertas. A indiferença do acesso ao "mundo circundante", apresentado pela percepção

\footnotetext{
209 "Sed forte, quamvis interdum sensus circa minuta quaedam et remotiora nos fallant, pleraque tamen alia sunt de quibus dubitari plane non potest, quamvis ab iisdem hauriantur: ut iam me hic esse, foco assidere, hyemali toga esse indutum, chartam istam manibus contrectare, et similia". René Descartes, Meditationes, Med. I, §4, p. 22.

${ }^{210}$ Idem, Meditationes, Med. I, §4, p. 24.

${ }^{211}$ Idem, Ibidem, Med. I, §5, p. 24.
} 
ou pelo sonho, não oferta qualquer certeza, mas apenas se confirma como obscurum. Eis aí a razão pela qual nem um, nem outro poderão atuar como o fundamentum da exigência metódica: quando não há absoluta clareza na relação (neste não-saber se estou desperto ou se sonho), ela jamais poderá ocupar o posto de principium; as coisas dadas desta maneira não passam de um "reino intermédio" (Zwischenreich), oscilando num território situado entre a res cogitans e a res extensa.

Mas se é verdade que estas singularia (coisas singulares) estavam impossibilitadas de compor o tão buscado fundamentum, o mesmo valerá para as generalia (coisas gerais) e para as universalia (coisas universais) ${ }^{212}$. Impulsionada pela suppositio falsi em sua procura pelo objeto magis simplex, a meditação jamais reconhecerá nestes saberes qualquer papel de fundação no edifício do conhecimento, uma vez que as disciplinas que lhe são correspondentes "dependem da consideração das coisas compósitas" (a rerum compositarum consideratione dependet) e podem, por isto, "ser de fato dúbias" (dubias quidem esse). Assim sendo, não parece haver ciência que não sofra, por esta razão, os efeitos da eversio. Mas o que pensar a respeito da aritmética e da geometria, que sempre souberam empregar as regras do método e tratar de objetos simples? É certo que as matemáticas já se provavam, desde as Regulae, ciências acuradas e imunes a qualquer tipo de obscurantismo, "pois esteja eu acordado ou dormindo, dois e três juntos são cinco e o quadrado não tem mais do que quatro lados" (nam sive vigilem, sive dormiam, duo et tria simul iuncta sunt quinque, quadratumque non plura habet latera quam quatuor $)^{213}$. Todavia, elas não podiam ofertar qualquer fundamentum absolutum para aquela preocupação com o conhecer: não obstante se bradasse ali que a eversio era o mais seguro ponto de partida para a conquista da certeza, sobrevivia na reflexão cartesiana um pressuposto que a impedia de conceder às matemáticas a honraria de situá-las no princípio; nem aritmética, nem geometria resistiam à dúvida porque a meditação é "prima philosophia, ontologia em sentido antigo", quer dizer, as regras lá estão para que se possa "proferir sentenças sobre o ser, sobre o ser-causa-última (Verursachtsein), sobre o ser de Deus" - e nenhuma sentença matemática poderia cumprir esta tarefa ${ }^{214}$. Se então sequer as matemáticas, em toda sua altivez, escapavam daquela quimérica exigência de uma

\footnotetext{
212 Para uma discussão mais ampla (e de forte inspiração fenomenológica) acerca desta questão, cf. Friedrich-Wilhelm v. Herrmann, Descartes’ Meditationen, $\S 1$-7, p. 25-84.

${ }^{213}$ René Descartes, Meditationtes, Med. I, §6, p. 26.

${ }^{214}$ Martin Heidegger, Einführung in die phänomenologische Forschung, GA 17, §41, p. 238. Sobre a noção cartesiana de prima philosophia e sua relação com definições escolásticas, cf. Jean-Luc Marion, Sur le prisme métaphysique de Descartes, $\S 1-5$, p. 9-72.
} 
ausência de pressupostos guiada pela convicção da mais antiga noção de filosofia, restava apenas a certeza de estar "diante do nada" e "no nada" das possibilidades como movimento inicial na procura pelo certo.

Contudo, essa negação da totalidade dos saberes não significaria, em momento algum, a vitória do ceticismo e a conformação de Descartes com a certeza única de que nada de certo poderia existir. Pois, ainda que afrontando o nada absoluto, a meditação prosseguia em sua busca, sendo guiada por uma Erwartungsrichtung. E era esta "direção dada pela expectativa" que, mesmo tendo "negado o caminho para algo"215 (isto é, para aquilo que se procura), encontrava o procurado no próprio procurar. Apenas aquele procurar tão regrado não sucumbia ao estratagema da dúvida hiperbólica; não podendo ser negado, o procurar dobrado sobre si mesmo era o fundamento que nulificava a negação "sem quase se mexer, sem dar um só passo fora de si mesmo e, de certo modo, sem sair do lugar" 216 . Mas de que maneira as Meditationes "chegavam" ali onde o meditar, por assim dizer, sempre estivera? Ora, dirá Descartes, mesmo que houvesse um gênio maligno e finório, cujo intento fosse apenas me enganar, ele jamais cumpriria sua tarefa. "E engane-me o quanto possa" (Et fallat quantum potest): está completamente fora de dúvida que sou porque me engana e enquanto penso "que sou algo" (me aliquid $e s s e)^{217}$; não há aí nenhum erro ou engano e não há outra conclusão possível senão aquela que compreende o ego sum, ego existo como o certo fundamental. E como a regula, que tudo toma pela mão e põe a caminho, perguntará Heidegger, determinará o Was deste ego? Descartes se indagava a princípio: será que a recusa da história da filosofia não passava de um excesso injusto e que a clássica determinação do homem já se apresentava como suficiente para o ser do ego? Quer dizer, quando se perguntava "quid est homo?" (“o que é o homem?”), para se responder aristotelicamente que o homem é animal rationale, havia nisto alguma certeza e evidência? Na verdade, se bem compreendido, o $\lambda \grave{y} \gamma o \nu$ " $\chi \omega \nu$ (a forma original para a qual animal rationale é apenas a tradução latina), antes de ser a resposta à questão, era um profundo desrespeito à letra da regra. $\mathrm{O} D e$ Anima cometia o gravíssimo erro de entender o fundamentum absolutum como um compositum, ofertando uma resposta complexa e desdobrando a pergunta "o que é o homem?" noutras tantas: "mas o que é um homem? Direi, por acaso, um animal racional? Não, porque seria preciso perguntar em seguida o que é um animal e o que é racional, de

\footnotetext{
${ }^{215}$ Martin Heidegger, Ibidem, GA17, §41, p. 240.

${ }^{216}$ Vladimir Jankélévitch, O paradoxo da moral, p. 16.

${ }^{217}$ René Descartes, Meditationes, Med. II, §4, p. 44.
} 
modo que, a partir de uma questão, eu resvalaria em muitas e mais difíceis questões". (sed quid est homo? Dicamne animal rationale? Non, quia postea quaerendum foret quidnam animal sit, et quid rationale, atque ita ex una quaestione in plures difficilioresque delaberer $)^{218}$. Mas se não o “animal racional" em sua intrínseca complexidade, a resposta que parecia surgir como mais imediata era que o homem consistia naquela "máquina de membros" conhecida como corpus. À primeira vista, uma resposta engenhosa em sua simplicidade - mas que se mostraria igualmente problemática por ter seu conhecimento atribuído por um modo de acesso não resistente à "suposição do falso" da eversio: já não se podia saber se o conhecimento deste corpo resultava de um sonho ou de uma percepção. Afinal, o que era então o ego? Ao que Descartes nos responderia de maneira pura e simples no cerne da segunda de suas meditações:

"Eu sou, eu existo; é certo. Mas por quanto tempo? Certamente enquanto penso (...) Mas o que sou, então? Coisa pensante. O que é isto? Certamente coisa que duvida, que entende, que afirma, que nega, que quer, que não quer, que imagina também e que sente ${ }^{, 219}$.

Na determinação daquilo que é (ou no jargão heideggeriano, de sua Wasbestimmung), o ego não poderia ser senão a cogitatio em si mesma, um animadvertere ou ato de lançar a visada para aquilo que deveria ser apreendido em seu sentido específico. Uma visada que se revelava a si mesma quando o ato de duvidar encontrava-se como a única certeza enquanto cogitare - e entendia que "eu sou" enquanto "eu penso" no momento em que a negação de todo ser tombava diante do ser da própria negação. Eis aí algo que os Principia não cessavam de rememorar: "recusa-se, pois, que isto que pensa, no mesmo momento em que pensa, não exista (...) Este que pensa, não pode não existir enquanto pensa" (repugnat enim, ut putemus id quod cogitat, eo ipso tempore quo cogitat, non existere [...] Is qui cogitat non potest non existere dum cogitat ${ }^{220}$. E as Meditationes ainda iam além. Pois, visto através das lentes heideggerianas, a reflexão não se resumia apenas no "serdado-conjuntamente do ser e do pensar" (mitgegeben-sein des Seins mit dem Denken) ou na determinação de seu Was, mas aludia também, já em seu momento originário, ao Wie

\footnotetext{
${ }^{218}$ Idem, Ibidem, Med. II, §6, p. 44-46.

219 "Ego sum, ego existo; certum est. Quandiu autem? Nempe quandiu cogito (...) Sed quid igitur sum? Res cogitans. Quid est hoc? Nempe dubitans, intelligens, affirmans, negans, volens, nolens, imaginans quoque, et sentiens". Idem, Ibidem, Med. II, §§7-9, p. 48-50.

${ }^{220}$ Idem, Principia Philosophiae, pars prima, $\S 7$ e $\$ 49$, p. 7 e 23-24.
} 
enquanto um modo de "ter-se-com" (Sich-mit-haben) ${ }^{221}$. Quer dizer, ao enunciar - no crepúsculo da segunda meditação - que a afirmação "cum videam” (quando vejo) em nada difere de "cum me videre cogitem" (quando penso que vejo), Descartes entendia como o modo de ser do cogito a proximidade que este sempre tem consigo mesmo, uma vez que, ao pensar algo, carecia de pensar que pensa algo (independentemente do que venha a ser este algo enquanto objeto). Deste modo, o cogito cartesiano era sempre um cogito me videre quando vejo, um cogito me sentire quando sinto, um cogito me imaginari quando imagino...Enfim, um cogito me cogitare a toda vez que um ato se cumpria. E estar diante de um cogito que não apenas encontra o certo fundamental, mas que o apreende a todo momento em que reencontra a si mesmo, é estar verdadeiramente diante daquilo que aplaca a preocupação com o conhecer e que faz gozar da tranquilidade (Beruhigung) de ter consigo o conhecimento conhecido.

Seria então o caso de reconhecermos que as Meditationes já continham em si, de forma tímida e como que escrita às margens do filão principal de sua argumentação, a semente daquilo que a filosofia batizará doravante de Selbstbewußtsein? E mesmo que não expressamente fixado (uma vez que a fórmula latina seria dada por Leibniz e a fórmula germânica se consagraria pela pena de Kant, na Crítica da Razão Pura), deveríamos assumir que aquele cogito me cogitare enquanto conhecimento conhecido era o antepassado do "discurso do acompanhar" (Rede vom Begleiten), no qual o "eu penso" deve poder acompanhar todas as representações? Questão aparentemente pertinente, mas que Heidegger fazia questão de afastar das reflexões sobre a preocupação cartesiana por ser, antes de tudo, uma euforia anacrônica: "enquanto se apreender a consciência interna como o fenômeno do acompanhamento, o qual pode e também não pode faltar, não se verá o momento que é decisivo para Descartes" ${ }^{222}$. E qual seria este momento decisivo da filosofia de Descartes? Justamente o fato de que a investigação cartesiana, antes que pudesse ser dita uma pura teoria do conhecimento do "discurso do acompanhar", caracterizava-se por ser regida por uma ideia de ontologia, cuja expressão mais nítida era dada "na esfera categorial do formalmente ontológico" (in der kategorialen Sphäre des formal Ontologischen $)^{223}$. E isto porque, se o certum era também o verum, a investigação

\footnotetext{
${ }^{221}$ Martin Heidegger, Einführung in die phänomenologische Forschung, GA 17, §44, p. 249. Sobre o modo como esta questão se apresenta ao longo da obra de Heidegger, cf. Christophe Perrin, 'Cogito me cogitare': note pour servir la généalogie et la téléologie d'une formule-clé de G.W.Leibniz à J.-L.Marion, Phainomena XXIII, 88-89, p. 5-23.

${ }^{222}$ Idem, Ibidem, GA 17, §44, p. 250.

${ }^{223}$ Idem, Ibidem, GA 17, §44, p. 248.
} 
não poderia somente assegurar uma esfera que respeitasse a exigência metódica e fornecesse o ponto de partida da totalidade das coisas, mas deveria dá-lo, sobretudo, como "uma certa proposição" (ein gewisser Satz): o cogito, ergo sum. Proposição esta que, se por um lado, enunciava o fundamento absoluto e simples, por outro, fazia descarrilar toda a preocupação em sua origem ao supor que aquele ancoradouro suficientemente seguro da certeza pudesse colocar termo à questão. Bastava então que se associasse o cogito ao sum para que o apressado Descartes pudesse concluir que "o sentido de Ser da res cogitans fosse determinado por este caráter de Ser enquanto proposição objetiva" e que "a questão do Ser da res cogitans estivesse liquidada de uma vez por todas"224. Noutras palavras, o "momento decisivo" da filosofia cartesiana era, por assim dizer, uma má decisão: o "encerramento" da questão no tão aguardado encontro com o ponto arquimediano só ocorria porque Descartes ignorava completamente o sentido do sum em favor daquela reluzente certeza do ego cogito, isto é, daquilo que permitia ao intelecto transitar pelo caminho da dedução em direção à outras proposições também certas. Para Heidegger, o notório das Meditationes estava menos numa cogitatio que se voltava a si mesma do que no fato de que esta volta não considerava relevante seu próprio "caráter estrutural" (Strukturcharakter). Afinal, era esta irrelevância, resultante da mera constatação da proposição, que tornava a filosofia cartesiana míope à coisa ela mesma: "o sentido do sum é esvaziado no sentido do ser-algo formal-ontológico" ${ }^{225}$. Ora, ainda que o ser-formal (na apreensão deste estado-de-coisas fundador) tivesse, para Descartes, a aparência do Ser absoluto, ele jamais colocara autenticamente a pergunta pelo Ser no curso de sua tarefa - pois, da maneira pela qual se apresentava, o cogito, ergo sum não somente ignorava a "questão do Ser", como também maturava toda sua busca, no progresso das meditações, numa espécie de Unbedürftigkeit em relação a ela. A bem dizer, o Ser enquanto tal permanecia velado em razão da violência interpretativa que insistia em apreendê-lo no sentido do esse certum. E seria esta prévia noção de certitudo qua veritas (certeza enquanto verdade) que permitiria Heidegger concluir sem reservas que "a tendência da pesquisa é dada deste modo desde o princípio: que não está em sua intenção colocar a questão do Ser" ${ }^{226}$. Era, portanto, a própria tendência inaugurada por

\footnotetext{
${ }^{224}$ Idem, Ibidem, GA17, §46, p. 256.

${ }^{225}$ Idem, Ibidem, GA17, §44, p. 250.

${ }^{226}$ Idem, Ibidem, GA17, §46, p. 255-256. O Ser não se desvelava nem na proposição, nem na determinação do ente como creatus, já que seu fundamento, o Deus creator, era também compreendido em sentido categorial: "Deus é apenas causa prima e absoluta do esse creatum". Cf. Martin Heidegger, Ibidem, GA17, $\S 45$, p. 252.
} 
Descartes que sentenciava sua preocupação; ela não fazia senão lançar a filosofia "no grotesco" (ins Groteske) ao conceder à ciência o posto sempre primeiro do Ser, tornandoo segundo e rebaixando sua determinação a um "domínio de ser", elaborado pela graça desta mesma ciência. "Em primeiro lugar, está a ciência e sua possível elevação em questão; em segundo lugar, está o Ser disto que é tratado, assim que, de fato, o conceito de Ser é determinado: Ser como possível domínio-de-ser para a elaboração por meio de uma ciência - um conceito de Ser que é decisivo [também] para Husserl”227.

\section{III - O Ser absoluto da consciência}

Era então graças a todo empenho empregado na formulação das Meditationes, afirmará Heidegger, que pela primeira vez ouvíamos o entoar de uma "preocupação com o conhecimento conhecido" no curso da história da filosofia. Mas se é verdade acrescenta ele - que o pensamento cartesiano fornecia assim o contorno de uma figura primordial, não se podia, por isso, supor que sua autenticidade como princípio já significava uma incontestável adesão à totalidade suas teses. Afinal, ainda que sustentasse a importante determinação de "passado originário", a filosofia de Descartes parecia não conhecer a concessão de indulgência por parte de seus sucessores. O preço a se pagar por ensinar os filósofos que tudo se iniciava com a exclusão de pressupostos - e que apenas a certeza era um operador válido - mostrara-se caro demais. E não deveria soar surpreendente o fato de que esta "cobrança" fosse levada ao seu limite justamente pela fenomenologia transcendental: mais do que qualquer outro filósofo, Husserl acatava tais mandamentos e fazia de sua doutrina nada mais que a purificação última daquela célebre "preocupação com o conhecimento conhecido".

Para que melhor se compreenda a tese heideggeriana, retornemos mais uma vez à Krisis. Mais especificamente, retornemos às lições sobre o pensamento moderno, ali onde Husserl fazia questão de rememorar ao seu leitor uma noção fundamental que se alastrava pela história da filosofia e regia o tom de seu discurso: determinação inquestionável,

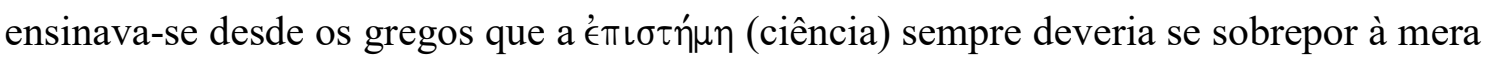
$\delta o ́ \xi \alpha$ (opinião) como forma de pensamento. E esta sobreposição parece não ter conhecido

\footnotetext{
${ }^{227}$ Idem, Ibidem, GA17, §46, p. 257.
} 
fortuna maior do que aquela que conhecera sob a pena de Galileu. Pois quando o mundo não mais se deixava compreender como o relativo, mas sim como o idêntico ou geometricamente ideal, esta objetividade nada mais era do que a radical consumação daquela superioridade do saber científico. Mas se este caráter de "ser objetivo", dirá Husserl, merecia ter seu mérito reconhecido por fundar a ciência moderna, isto parecia não o eximir de certos pecados cuja constatação não tardaria a surgir: ainda que favorecesse a forma universal em detrimentos das oscilações particulares, ocupando-se apenas com a coisa em si, esta "nova ciência matemática da natureza" não passava ainda e "em primeiro lugar de uma ingenuidade". Ingenuidade esta que o gênio de Descartes não tardaria a reconhecer, insistindo que aquela - ao menos até então - “óbvia objetividade" (selbstverständliche Objektivität) deveria "tornar-se um problema" ${ }^{228}$. Mas por qual razão a tão louvada objetividade transitava agora, muito velozmente, de descoberta fulcral a motivo de indagação? Porque se é verdade que Galileu havia ensinado aos bons filósofos como lidar de maneira objetiva com aquele terreno dos acidentes que é a própria natureza, também é verdade o fato de que ele jamais havia se questionado como a atividade de uma "alma científica" poderia propor uma verdade objetiva. Não que Descartes pretendesse com isto questionar a legitimidade da reflexão galileana. Muito pelo contrário: para ele, os ganhos desta doutrina eram inegáveis; esta nova concepção de mundo merecia reconhecimento porque era verdadeiramente científica. Na verdade, tudo se passava como se uma ciência tão correta e necessária tivesse desprendido tamanha atenção na formulação deste saber que terminava por dar as costas a uma pergunta ainda mais imediata: como as operações do entendimento chegavam a acontecer e como aquilo que nela se gerava adquiria um valor objetivo?

Ora, será justamente esta questão que o ego cogito das Meditationes viria responder. Se até então as ciências se desdobravam sem conceber exatamente como ocorriam suas operações, com a descoberta do ego cartesiano elas passariam a conhecer o "solo fundamental" (Urboden) onde o "sentido" e o "direito" de toda objetividade fincavam suas raízes. Tudo se encontra nele fundado e para ele "devo eu retornar enquanto solo último e absoluto para toda fundamentação última do entendimento que possibilita a operação objetiva" 229 . E se é assim, pode-se muito bem dizer que é somente a partir daí que o entendimento se converterá em tema de uma investigação. Portanto,

\footnotetext{
${ }^{228}$ Edmund Husserl, Krisis, Beilage VII zu §18, p. 412.

${ }^{229}$ Idem, Ibidem, Beilage VII zu §18, p. 414. Cf. também Beilage VI zu §16, p. 405-406.
} 
saudemos Descartes, uma vez que é graças ao seu engenho que o ego ocupará o papel de protagonista na cena filosófica. Mas saudemos, todavia, com muito comedimento - este será o reiterado conselho de Husserl: embora devamos a Descartes a primeira abertura ao âmbito da consciência, não nos esqueçamos de que sua "virada radical" (radikale Umwendung) era radical apenas em aparência. E é sobre isto que a Krisis não cansa de nos advertir. Quando bem compreendida, a eversio cartesiana mostrava-se insuficiente e, por este motivo, a segunda meditação não fazia senão nos guiar até o limiar do verdadeiro fundamento, abandonando-nos com sua promessa de universalidade na porta de entrada "da subjetividade transcendental na forma deste ego". Eis aí uma queixa que se deixava entrever também nas Meditações Cartesianas: "o que a meditação transcendental de si da fenomenologia - perguntava Husserl - tem a dizer sobre isso? Nada além de que todo este problema é absurdo, um contra-senso no qual o próprio

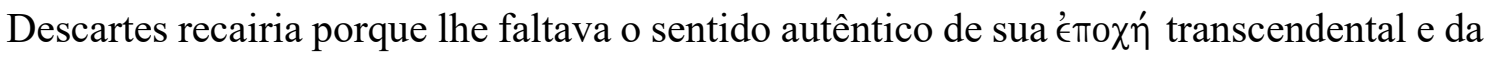

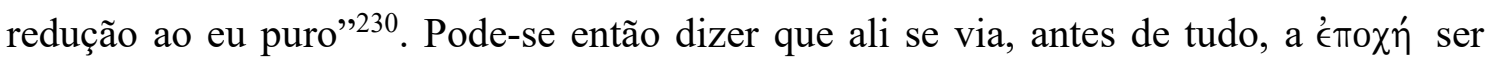
abandonada com a mesma ansiedade com a qual fora evocada, agora em favor da conservação da boa tese galileana. Pois Descartes censurava Galileu simplesmente por não ter determinado a essência do sujeito, mas de modo algum por ter elaborado a doutrina de um "mundo em si", ontologicamente independente. Na verdade, este era o grande lance filosófico dos Diálogos e do Ensaísta. Afinal, ao propor que observássemos o mundo como geômetras, Galileu não somente se ocupava daquelas "coisas puramente corpóreas" (resultado da abstração "dos sujeitos enquanto pessoas de uma vida pessoal, de qualquer traço espiritual em todo sentido, das propriedades culturais atribuídas às coisas na práxis humana"), como também instituía uma espécie de "contra-abstração" que nada mais era do que o "ser psíquico". O mundo obtinha assim um significado até então desconhecido, passando a ser interpretado como um "mundo cindido" em dois, "numa natureza em si e num modo de ser distinto dela", a alma ${ }^{231}$. Nesse sentido, "a revolução galileana não se limita a fundar uma nova física: sob o fundo da nova concepção de natureza é a própria significação de 'mundo' que se altera e o dualismo cartesiano que se antecipa" ${ }^{" 232}$. Ora, ao opor o ponto arquimediano a uma esfera outra que o transcendia, Descartes não fazia senão acatar “ingenuamente” em suas Meditationes o juízo proferido por Galileu; ele permanecia como bom e fiel sequaz da formulação inaugurada pela

\footnotetext{
${ }^{230}$ Idem, Cartesianische Meditationen, §41, p. 116.

${ }^{231}$ Idem, Krisis, $\S \S 10-11$, p. 60-62.

${ }^{232}$ Carlos Alberto Ribeiro de Moura, Husserl: significação e existência, in: Racionalidade e Crise, p. 164.
} 
ciência matemática da natureza: "o dualismo cartesiano requer o paralelismo da mens e do corpus e a realização da naturalização nele implícita do ser psíquico, e com isto também o paralelismo da exigida metodologia" 233 . E era a partir desta aceitação silenciosa que surgiria o problema cartesiano fundamental a mover toda a teoria do conhecimento, a saber, o questionamento de como é possível obter um "conhecimento objetivo" no encontro das esferas de ser. A pergunta que viria a se instalar no cerne do pensamento filosófico, dirá Husserl, seria a seguinte: se eu me percebo como um "homem natural", inserido previamente num mundo espacial (do qual também sou parte), como posso conhecer este Außer-mir que se apresenta, "como saio de minha ilha de consciência, como posso obter uma significação objetiva do que se comporta em minha consciência como vivência evidente?" 234 . Desde então, era com base na separação entre res cogitans e res extensa que veríamos a fundação absoluta do conhecimento situar-se na alma pura, em oposição ao mundo extra-anímico. Era o dualismo que nos convidava a observar a questão do conhecimento como aquela da transposição do espírito à natureza, de um interior que se dirige a um exterior. Era ele, portanto, que permitia-nos encontrar na representação a solução do problema do conhecimento, uma vez que esta já estivesse assegurada pela veracitas divina.

O que devemos compreender quando nos referimos ao ato de conhecer como representação? Qual é a essência desta doutrina que as Meditationes parecem ter impresso de modo incontestável nas obras dos filósofos que as sucederam? A representação, esclarecia Descartes a Burman, nada mais era do que uma imagem (imago). Não uma imagem tomada em seu sentido vulgar, entendida como efígie ou uma pintura de algo que se pretenda retratar (... quod ad aliud effigiatum est et depictum). Nada disso. A expressão tanquam imago ou "ter a imagem de alguma coisa", esclarecerá Heidegger em seu A época da imagem do mundo, significava, antes de tudo, "representar" (vorstellen) na medida em que o verbo figurasse como sinônimo de "colocar o ente diante de si (vor sich stellen), tal e qual é, e tê-lo diante de si enquanto ente assim permanentemente colocado"235. Daí a "imagem do mundo" nada mais ser do que a colocação da totalidade do ente diante do homem. Não de um homem entendido conforme a vagueza de alguma determinação corriqueira, disseminada pelo senso comum, mas de acordo com uma elaboração conceitual até então inovadora: com Descartes, o homem se

\footnotetext{
${ }^{233}$ Edmund Husserl, Krisis, §64, p. 224.

${ }^{234}$ Idem, Cartesianische Meditationen, $\$ 41$, p. 116.

${ }^{235}$ Martin Heidegger, Die Zeit des Weltbildes, in: Holzweg, GA 5, p. 89.
} 


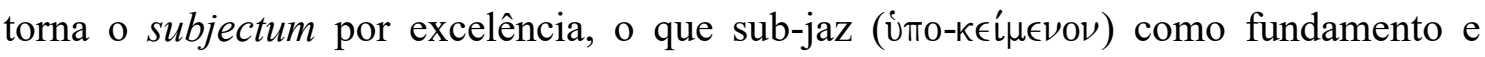
sustentáculo de todo ente em seu ser e em sua verdade. Para que o representar possa então ser dito o "colocar diante do homem", é preciso que ao homem mesmo esteja reservada a definição de "vorstellend-herstellend", quer dizer, que seja aquilo que permita ao ente ser somente se colocado (gestellt) diante (vor) e a partir (her) dele. Assim, quando o homem se torna o referencial axiomático, "o ser do ente é procurado e encontrado na representatividade do ente", e qualquer "coisa" cuja "colocação" se furte ao vor e ao her não fornecerá nenhum conhecimento, nem poderá ser reconhecida como "ente" - ou em jargão cartesiano, ela simplesmente não resultará em nenhuma imagem ${ }^{236}$.

Não ousemos, portanto, buscar este ideal de uma "imagem do mundo" junto aos pensadores medievais. Caso pretendêssemos ali encontrá-lo, certamente nos frustraríamos: para o homem do medievo se reserva apenas a concepção de ente colocada sob a rubrica do ens creatum, uma criatura sempre à sombra do Deus criador, que nada mais é do que a última e mais elevada de todas as causas. Frustração ainda maior experimentaríamos - prevê Heidegger - caso tentássemos obter dos gregos uma confissão de uso desta noção de imagem. Afinal, ainda mais do que o conceito medieval, o ente grego (e a compreensão da verdade que o perpassa) tende a se afastar do moderno. Como prova disso, que se consulte a antiquíssima expressão de Parmênides, traduzida por Heidegger da seguinte maneira: "pertence ao Ser, porque por ele exigido e determinado,

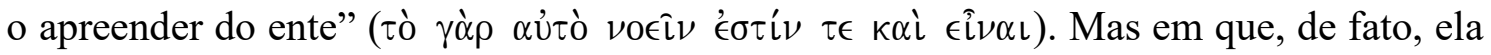
nos ajuda a demarcar a distância que separa o ente tal como os gregos o concebiam do ente delineado pelas Meditationes? Ora, esta exumação do verso parmenídeo lá está para nos rememorar que na origem, antes de ser o assegurado na violenta certeza da representação, o ente é o aberto na presença, aquilo que o homem descerra porque, também ele, está presente e aberto à apreensão. Ao filósofo grego nada soava mais incomum que a afirmação de que o ente passa a ser porque o homem o percebeu (anschauen) "no sentido do representar à maneira de uma percepção subjetiva"; era-lhe, na verdade, mais habitual ouvir que o ente percebia o homem (...der Mensch der vom Seienden Angeschaute...), que o retinha e o carregava em sua abertura, e que, por isso mesmo, "o homem precisava, para preencher sua essência, recolher $(\lambda \dot{\epsilon} \gamma \epsilon \iota \nu)$ e salvar $(\sigma \omega ́ \zeta \epsilon \iota \nu)$, acolher e preservar, e permanecer exposto à toda confusão cindível

\footnotetext{
${ }^{236}$ Idem, Ibidem, GA 5, p. 89-90.
} 
$(\dot{\alpha} \lambda \eta \theta \epsilon \cup \in \epsilon \iota \nu)$ "237. Daí o homem não conceber o mundo enquanto imagem: quando grego, ele é o Vernehmer, ou seja, é quem apreende o ente que se abre no momento mesmo em que se abre ao ente. E antes que o platonismo viesse a lhe perverter o sentido, era justamente isso que a filosofia de Protágoras pretendia ensinar: $\pi \alpha \dot{\alpha} \nu \tau \omega \nu \chi \rho \eta \mu \alpha^{\prime} \tau \omega \nu \mu \mu^{\prime} \tau \rho o \nu$

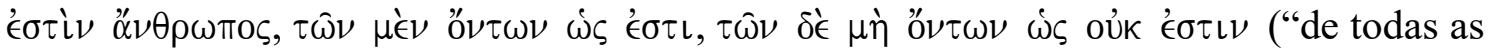
coisas [ou seja, de todas que o homem usa e necessita, e que por isso tem permanentemente junto a si, $\chi \rho \eta ́ \mu \alpha \tau \alpha \chi \rho \hat{\eta} \sigma \theta \alpha \iota]$ o [respectivo] homem é a medida, das que estão presentes, que e como estão presentes, e daquelas para as quais permanece negado estar presente, que não estão presentes") ${ }^{238}$. Mas se a medida é o que marca a essência do homem no encontro com o ente, de que maneira compreender sua equivalência ao conceito de Vernehmer? Simplesmente abandonando nossas engessadas convicções escolares e sabendo reconhecer que também ali, no pensamento sofístico, a figura de um '́үَ' desempenha um papel crucial. Todavia, não sejamos ingênuos - recomendará Heidegger - a ponto de supor que este "eu" tenha algum traço do vulto moderno, como se pressagiasse o ego da segunda meditação. Este "eu”, grafado em grego clássico, é totalmente distinto de seu "falso gêmeo" cartesiano: ele se deixa ver como aquele que se demora (Verweilen) no âmbito (Umkreis) dos desvelados e que apreende o ente em seu desvelamento; o “eu” protagórico é, antes de mais nada, o que está aí, demorando-se e permanecendo junto ao presente, estando também ele na própria presença. E se a todo

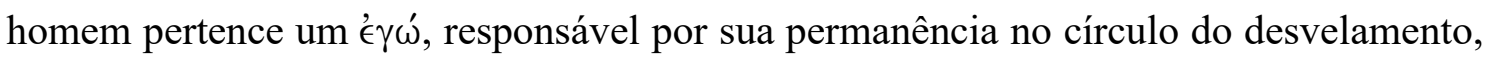
tudo se passa como se o homem mesmo fosse o único capaz de atestar o que está presente (e por isso é) e o que está ausente (e por isso não é). Mais do que isto: "o homem da relação fundamental grega com o ente e de seu desvelamento é o $\mu^{\prime} \in \tilde{\tau} \rho \nu$ (medida), contanto que ele assuma a mensuração sobre o âmbito delimitado de modo egóico e, por conseguinte, reconheça o velamento do ente e a indecisão sobre sua presença ou ausência, e igualmente sobre o aspecto do permanente" ${ }^{239}$. Se somos então a medida, exclamará Protágoras, saibamos reconhecer o que se manifesta na dimensão de nossa própria esfera (desvelamento) e guardemo-nos de proferir qualquer sentença acerca daquilo que a excede (velamento); ocupemo-nos apenas do ente que aí se abre e jamais ousemos tratar,

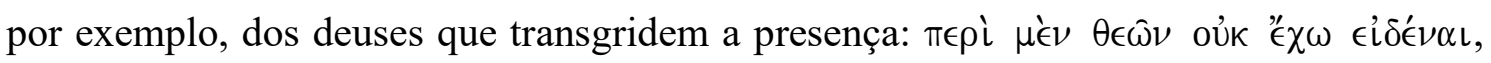

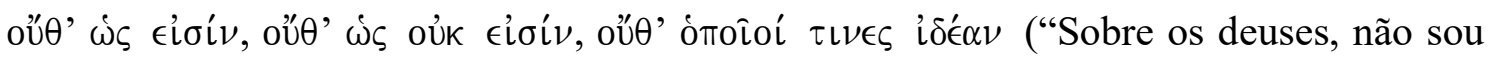

\footnotetext{
${ }^{237}$ Idem, Ibidem, GA 5, p. 91.

238 Platão, Theaetetus, 152a.

${ }^{239}$ Martin Heidegger, Die Zeit des Weltbildes, in: Holzweg, GA 5, p. 105.
} 
capaz de saber algo claramente [isto é, de modo grego, 'chegar a ver' algo]: nem que são,

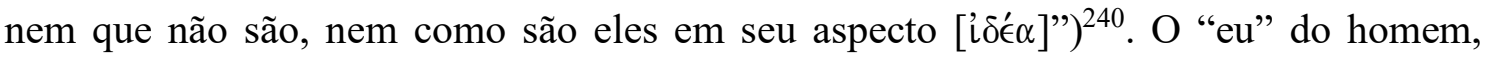
portanto, não é nenhuma celebração precoce do subjectum de Descartes, bem como não é "medida" por ser fundamentum inconcussum - pois, como sublinhará Heidegger, "todo subjetivismo é impossível na sofística", não apenas porque o homem recusa a determinação de "sujeito", mas também porque "o Ser aqui é presença e a verdade é desvelamento" $" 241$.

Pode-se então dizer sem reservas que qualquer comparação entre tais concepções será indevida e que qualquer sobreposição conceitual entre elas soará falsa. Mas é possível também ir além: elas não se deixarão confundir em nenhum momento porque é justamente contra aquela ontologia primordial, gestada na filosofia pré-socrática, que o representar irá se levantar. E qual será a descrição última da representação, aquilo que, enfim, irá opô-la à noção fundamentalmente grega? Aos olhos de Heidegger, o representar será sobretudo a recusa do pacifismo regente na apreensão grega do ente e em sua concepção de verdade. Afinal, quando Descartes inaugura a representação, ele o faz de modo a se afastar da mansuetude tipicamente grega do "descerrar-se para..." (Sich entbergen für...) em direção à violência do "capturar..." ou "compreender de ..." (Ergreifen und Begreifen von...). Agora, "não é o presente que domina, mas sim o ataque (Angriff)" ${ }^{242}$. E que não se estranhe, pois, o fato de que o ente seja entendido como o certum: abandonando a brandura de ser aberto na presença, ele passa a ser o resultado dum cernere, quer dizer, é o fruto daqueles golpes lapidares que a razão desfere sobre algo, a fim de que não reste acerca dele qualquer dúvida; já não há o ente que se desvela pacificamente ao homem, mas há uma razão beligerante, atacando-o para prová-lo em sua certeza, para fazê-lo digno da alcunha “objeto". Ora, é justamente isto que ensina o final da segunda meditação. Sobre um pedaço de cera - que ora se apresenta como sólido, frio, com odor de flores e sabor de mel, e ora liquefeito, calefacto, inodoro e insípido - não se pode responder à questão "remanetne adhuc eadem cera?" ("remanesce ainda a mesma cera?") com um categórico "remanere fatendum est" ("é preciso confessar que remanesce") simplesmente porque o ente nos fora desvelado na presença. Uma tão austera confissão de permanência somente pode ocorrer, afirmará Descartes, porque "diligentius

\footnotetext{
${ }^{240}$ Diels-Kranz, Die Fragmente..., Protagoras, B4.

${ }^{241}$ Martin Heidegger, Die Zeit des Weltbildes, in: Holzweg, GA 5, p. 106.

${ }^{242}$ Idem, Ibidem, GA 5, p. 108.
} 
investigavi" ("investiguei de modo mais diligente") o que é a cera e como posso conhecêla:

"Mas o que é esta cera, que não é percebida senão pela mente? Certamente a mesma que vejo, que toco, que imagino, a mesma, enfim, que desde o início acreditava ser. Ora, o que é preciso notar é que sua percepção não é o ato de ver, de tocar, de imaginar, e nunca o foi, embora antes o parecesse, mas é inspeção apenas da mente, que pode ser imperfeita e confusa, como antes era, ou clara e distinta, como agora é, conforme presto menos ou mais atenção às coisas que a compõem "243.

Eis aí a profunda ruptura que as Meditationes trarão em seu bojo: não há ente sem que haja o processo de "inspeção da mente", sem o ato de colocá-lo diante de si (vor-stellen), levando-o ao seu encontro e contra ele, tornando-o "ob-jetivo" (Das Gegenständige). Apenas a representação concede a algo o privilégio de ser, visto que é ela a fixar o ente definitivamente (er-stellen) ao colocá-lo diante (vor-stellen) do homem, fazendo-o jazer defronte (ob-iacere): "Vor-stellen ist vor-gehende, meisternde Ver-gegenständlichung"244. Portanto, não é pela graça de nenhuma decisão fortuita que o representar surgirá como a essência do pensamento: por consistir na impetuosa tomada do ente, não há coerência maior do que fazê-lo figurar como a co-agitatio (em oposição à tranquillitas do desvelamento). E se é assim, a lição a reter disso tudo, acentuará Heidegger, é que o pensamento moderno se afirma e se firma no curso da história da filosofia por meio desta violência. Violência na conquista do mundo como imagem, mas sobretudo como resultado de uma luta (Kampf). Afinal, não se pode tratar da representação sem que se contemple o cenário que se descortina por detrás de seu surgimento, sem que se observe a batalha travada por conta do estabelecimento do lugar a ser ocupado pelo conceito de

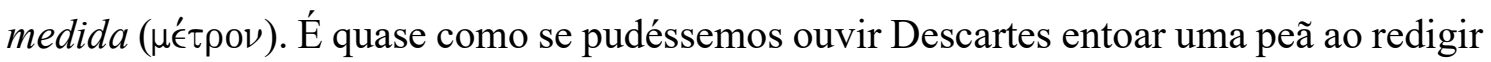
sua obra: combate-se para retirar a medida da esfera do desvelamento e situá-la terminantemente no homem enquanto "ente que fornece a norma a todo ente e estabelece o parâmetro", quer dizer, de encontrá-la no ente que faz uso da razão tal como se faz uso

\footnotetext{
243“"Quaenam vero est haec cera, quae non nisi mente percipitur? Nempe eadem quam video, quam tango, quam imaginor, eadem denique quam ab initio arbitrabar. Atqui quod notandum est, eius perceptio non visio, non tactio, non imaginatio est, nec unquam fuit, quamvis prius ita videretur, sed solius mentis inspectio, quae vel imperfecta esse potest et confusa, ut prius erat, vel clara et distincta, ut nunc est, prout minus vel magis ad illa ex quibus constat attendo". E continuará: "Atque id quod putabam me videre oculis, sola judicandi facultate, quae in mente mea est, comprehendo" ("Assim, isto que acreditava ver com os olhos, compreendo apenas pela faculdade de julgar, que está em minha mente"). René Descartes, Meditationes, II Med., §§13-14, p. 56-58.

${ }^{244}$ Martin Heidegger, Die Zeit des Weltbildes, in: Holzweg, GA 5, p. 108.
} 
de um cinzel, "lavrando" o ente, libertando-o de toda incerteza e estabelecendo-o como objeto.

Mas mediante esta longa digressão pela essência da filosofia cartesiana, é cabível perguntar: no fim das contas, o que a fenomenologia terá a ver com este prélio desencadeado pela representação? Ora, a fenomenologia nada mais é do que o ferrenho opositor de tamanha violência, é a fórmula pacificadora ou doutrina responsável por reconhecer as dificuldades internas do representar e por estancar a "sangria" desencadeada pelo "ataque" característico de uma tal teoria do conhecimento. É que, para Husserl, já não há sentido em falar o idioma da representação, uma vez que a própria noção de dualismo desvanece em face da redução. Como dizer, pergunta-se ele, que o conhecimento resulta do encontro - ao que tudo indica - nada amistoso entre duas esferas de ser, se a duplicidade da substância se mostra falaciosa? Como continuar a sustentar esta tese absurda quando tudo se encontra colocado entre parênteses e a própria ideia de

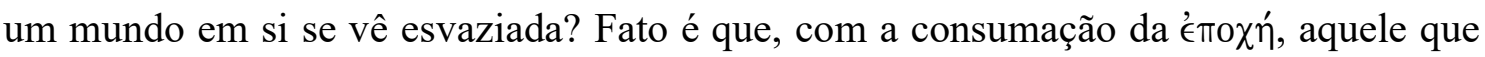
reafirma a validade do representar deve saber que cederá, inelutavelmente, à ingênua triga cartesiana; e isto não apenas por aceitar inconteste o pré-juízo galileano, mas sobretudo por subscrever uma tese completamente cega em relação ao âmbito subjetivo. Pois se é verdade que Descartes nos conduzia às portas da verdadeira subjetividade, também é certo que ele jamais as adentrara: quando as Meditationes encontravam o ego, não tardavam a submetê-lo ao seu afã de confirmar a existência das regiões "interior" e "exterior", contentando-se apenas em tomá-lo como o ponto de partida de uma série dedutiva. Que a subjetividade tivesse ali sido vislumbrada e empregada a um propósito, não significava que tivesse sido sistematicamente investigada. A bem dizer, o mero encontro poderia parecer satisfatório para quem se permitia desrespeitar o preceito da eversio, mas soava como falta de rigor para quem o seguia seriamente. Eis aí uma sentença que Husserl não cansará de repetir: "isto é algo completamente natural, uma vez que a vida subjetiva, que aí se chama vivenciar, foi velada em sua essência e nunca foi estudada"245; em sentido estrito, a pompa inaugural do "conhecimento conhecido" que emanava da pena de Descartes revelava-se apenas uma fórmula vazia, visto que o "conhecimento" jamais fora efetivamente "conhecido". Assim, ao constatar que tudo ainda resta por fazer, a fenomenologia poderá reivindicar para si a tarefa de elucidar um fundamento que não é mais compreendido - erroneamente compreendido - "como o 'a-partir-do-qual' de um

\footnotetext{
${ }^{245}$ Edmund Husserl, Erste Philosophie, I, p. 81.
} 
proceder, mas sim como o 'acerca-do-qual' de uma ciência" ${ }^{\text {"246 }}$. E tendo em vista esta pretensão, já não haverá outro começo possível para tal ciência rigorosa, reconhece Husserl, senão uma verdadeira exclusão de pressupostos, capaz de pôr definitivamente um fim ao extravio provocado pela oposição entre duas regiões ontológicas. Mas se, por princípio, é vedado a todo fenomenólogo exprimir-se nos termos da representação, como entender esta subjetividade e sua relação com o objetivo? Simplesmente sabendo que o "subjetivo" e o "objetivo" não se diferenciam no momento em que se assume a orientação fenomenológica. É o que, mais uma vez, a Krisis irá relatar: não há mais o “objetivo" ao gosto da tradição, pois, "com base no atual método da epoché, todo objetivo se modifica em subjetivo", ou seja, "o mundo, o objetivo, torna-se ele mesmo um subjetivo peculiar", sendo apenas "o correlato das manifestações subjetivas, das visadas, dos atos e poderes subjetivos" 247. Desde então, toda interpretação que contrapõe "o mundo ôntico" à "representação humana do mundo" e que situa a pergunta "pelo subjetivo, pelos elementos anímicos do homem, no solo de um mundo obviamente e efetivamente ôntico", carecerá de sentido. "Nossa cientificidade - insistirá Husserl contra os epígonos de Descartes - não é a da psicologia", e seu discurso "não se origina em nenhuma psicologia científica e em suas questões”. Na verdade, a cientificidade fenomenológica será de outra ordem porque cumprirá uma antiga promessa de rigor. Emanando de uma subjetividade transcendental pura, sua retórica será aquela do "subjetivo que se relativiza de uma maneira paradoxal", quer dizer, será a descrição do "paradoxo" presente naquilo que se relativiza (em face das subjetividades históricas depauperadas) para provar-se como absoluto: "na epoché, um conceito geral de subjetivo engloba tudo, quer se trate do pólo egológico e do universo dos pólos egológicos, ou das multiplicidades de manifestações, ou dos pólos objetivos e do universo dos pólos objetivos"248.

E qual lição se reterá desta instituição da fenomenologia transcendental? O que Husserl irá meticulosamente ensinar, aponta Heidegger, é que a clássica doutrina do dualismo não poderá ofertar - e isto na mais benevolente das concessões - senão uma vaga sombra do ego. Ao cartesiano que insistia em reafirmar sua devida investigação por parte das Meditationes (e que, por esta razão, era-lhe permitido transitar indubitavelmente ao conhecimento de um mundo tomado em si), o fenomenólogo iria provar que sua

\footnotetext{
${ }^{246}$ Martin Heidegger, Einführung in die phänomenologische Forschung, GA 17, §44a, p. 259.

${ }^{247}$ Edmund Husserl, Krisis, §53, p. 183.

${ }^{248}$ Idem, Ibidem, §53, p. 182-183. Cf. Carlos Alberto Ribeiro de Moura, Cartesianismo e Fenomenologia, in: Racionalidade e Crise, p. 217-218.
} 
suposta teoria não passava de um flatus vocis. Pois era somente com o advento do absolutismo do subjetivo que se podia dizer sem receio que o conhecimento havia sido de fato conhecido. No entanto, se é certo que a consciência absoluta parece levar a termo a velha tarefa da teoria do conhecimento, desbravando o território até então inóspito da subjetividade, resta ainda saber a que Husserl se refere quando emprega a determinação "absoluto". Ora, é justamente esta pergunta fundamental que Heidegger não hesitará em se colocar em seu Prolegômenos para a história do conceito de tempo. Reconhecendo ali que "a intenção da fenomenologia transcendental caminha em direção à descoberta de um novo domínio científico", e que esta "nova região" por ela desvelada não poderia ser outra senão aquela "das vivências puras, da consciência pura com seus correlatos, da região do puro eu"249, Heidegger nos instruía que o derradeiro esclarecimento da preocupação com o conhecimento conhecido apenas poderia emergir do desdobramento da seguinte questão: "enquanto campo fundamental da intencionalidade, como a região consciência - consciência pura - é determinada em seu ser?" Quer dizer, se a promessa não cumprida de Descartes podia encontrar seu desfecho nas meditações de Husserl, era somente porque respondia a indagação: em qual sentido a consciência pode ser dita absoluta? Ou em jargão tipicamente heideggeriano: "Was heißt hier absolutes Sein?"250

Mas se é assim, qual resposta obteremos da parte de Husserl? A julgar pela descrição apresentada no primeiro livro de Ideias, ela certamente será uma noção que não goza da prerrogativa de ser unívoca. E isto porque, ao se deparar com o Ser da consciência, a fenomenologia transcendental terá diante de si nada menos que um absoluto de caráter plural, um absoluto cujo encontro não poderá significar senão a remissão aos seus múltiplos sentidos. Donde Heidegger, ao expô-lo à sua audiência, não se referir à "determinação de Ser", mas sim a "determinações de Ser": "nós discutiremos em pormenor as determinações de Ser que Husserl confere à consciência pura" ${ }^{251}$. Mas antes que se possa empreender a tarefa de descrever cada uma destas determinações, é necessário compreender, de partida, que elas não apenas se encontram "atreladas entre si”, como também são indissociáveis do conceito de imanência. E convém precisar que não nos forçamos a nenhum recuo à orientação natural ao evocarmos esta figura da “imanência": é coisa muito bem sabida que, desde $A$ ideia da fenomenologia, ela adquire

\footnotetext{
${ }^{249}$ Martin Heidegger, Prolegomena zur Geschichte des Zeitbegriffs, GA 20, §10b, p. 131.

${ }^{250}$ Idem, Ibidem, GA 20, §11, p. 140-141. Cf. Jocelyn Benoist, Egología y fenomenologia: la crítica heideggeriana de Husserl, p. 21-42.

${ }^{251}$ Idem, Ibidem, GA 20, §11, p. 141-142.
} 
uma feição muito particular, purgada de toda acepção psicologista. Ora, que se releia atentamente a segunda preleção, a fim de se evitar um quid pro quo. Sublinhando ali a duplicidade existente nos termos imanente e transcendente, Husserl proibirá todo fenomenológo de partilhar da decisão da psicologia em traduzir, por um lado, o imanente como todo conteúdo "realmente (reell) contido num ato" e, por outro, o transcendente como "o não-estar-realmente-contido do objeto do conhecimento no ato", isto é, como aquilo que não constitui um momento do ato ele mesmo, sendo o que está além dele, $a$ coisa em si $^{252}$. Afinal, se em regime de redução é a "dignidade do objeto" que desaparece, e com ela desaparece também toda legitimidade da representação, estas definições vigentes no discurso psicológico não passam de contra-senso; empregá-las seria recuar à condição do "principiante" que insiste em reproduzir o "erro funesto" da tradição. É que para a fenomenologia transcendental os acentos vão cair de maneira diversa sobre os conceitos: a transcendência deixa de remeter ao mundo em si, completamente apartado da consciência, e passa a designar "todo não evidente", todo "objetivo" que, embora colocado e considerado, "não é um conhecimento que intui a si mesmo"; a imanência, por sua vez, deixa de ser entendida como o conhecimento contido no ato e se metamorfoseia "num intuir e apreender diretos da objetividade mesma que é significada tal como é, que constitui o expressivo conceito de evidência, e que é certamente compreendido como evidência direta" ${ }^{253}$. Deste modo, ao se referir a uma imanência fenomenológica, Husserl não pensava senão na específica direção de um ato que se volta para as próprias vivências, numa reflexão cujo resultado só pode ser a "relação do real (reell) estar encerrado um no outro" - quando "um" e "outro" já não se distinguem. Imanência é, portanto, um in-manere: permanência no interior de uma mesma região, na qual as vivências se dobram sobre si mesmas na clareza da compreensão ${ }^{254}$.

É somente a partir daí, em posse da ideia de que não transcendemos a esfera da consciência quando nos orientamos fenomenologicamente, que estaremos autorizados a delinear os sentidos assumidos pelo absoluto. Sendo assim, o primeiro dos traços que o engenho de Husserl nos dará a conhecer será aquele de uma "consciência que é um ser absoluto no sentido de uma doação absoluta". Mas o que significa ser uma "doação absoluta"? Significa dizer que ela é, antes de tudo, a principal conquista da fenomenologia, o fruto que apenas ela soubera colher porque, graças ao seu método,

\footnotetext{
${ }^{252}$ Edmund Husserl, Die Idee der Phänomenologie, II. Vorlesung, p. 35.

${ }^{253}$ Idem, Ibidem, p. 35-36.

${ }^{254}$ Martin Heidegger, Prolegomena zur Geschichte des Zeitbegriffs, GA 20, §11a, p. 142.
} 
aprendera a mover-se "inteiramente nos atos da reflexão" ${ }^{255}$. E o que vinha a ser este solo da reflexão sobre o qual a fenomenologia transcendental transitava, era justamente o que o livro de Ideias se empenhava em definir. De fato, era ali que se podia ouvir Husserl proferir, com toda limpidez na entonação, que refletir consistia num ato de tipo muito específico, cuja função residia em nos livrar definitivamente dos prejuízos filosóficos dos quais nos tornamos herdeiros. Pois é na contracorrente do pensador de orientação natural, para quem o simples vivenciar do conteúdo dos atos mostra-se suficiente, que o fenomenólogo "insatisfeito" com os pressupostos vigentes vai apontar aquilo que escapa ao seu adversário, ou seja, que em cada uma destas vivências (nas quais "ingenuamente" se vive) repousa uma "possibilidade ideal" fundamental: "toda vivência que não está na visada pode chegar a ser 'vista' segundo uma possibilidade ideal; uma reflexão do eu dirige-se para ela, e agora ela se torna o objeto para o eu" ${ }^{256}$. Ora, por trajar as vestes do dogmatismo, o filósofo da tradição irá ignorar aquilo que, "por princípio, toda consciência pode experimentar"; ele não se dará conta do fato que esta mesma consciência pode e deve sofrer uma modificação essencial, abdicando da visada lançada ao mundo em favor da visada voltada a si mesma; no fundo, o que parecia restar-lhe incompreendido não era apenas o sentido do termo refletir (que é um outro nome para o movimento de uma vivência dirigida à outra vivência, para um ato que se consuma enquanto apreende outro ato), mas também que "somente por meio dos atos reflexivamente experimentados que nós sabemos algo do fluxo de vivências e de sua relação necessária com o eu puro" 257 . Assim, era graças a esta perda de dimensão da própria reflexão, assegura Husserl, que as doutrinas históricas jamais puderam alcançar "a coisa ela mesma". Afinal, se elas nada sabiam do ponto de partida, o que poderiam dizer do território onde se aportava? Por tergiversarem à possibilidade ideal de refletir, elas não entreviam que, neste encontro imanente, já se anunciava o ser da consciência: da vivência dada a si mesma, numa entrega sem entremeios, não se obtinha senão uma intuição e uma apreensão totalmente evidentes, uma "doação absoluta e clara, Selbstgegebenheit em sentido absoluto" 258. Desde então, estas "doações contrapostas à transcendência", sempre arredias ao "indireto" e ao "simbólico", só poderão representar a derrocada do psicologismo. E ao assecla iracundo, que insistia em nutrir o mau hábito de esbravejar "eu duvido da

\footnotetext{
${ }^{255}$ Edmund Husserl, Ideen I, §77, p.162.

${ }^{256}$ Idem, Ibidem, $\$ 77$, p. 162.

${ }^{257}$ Idem, Ibidem, §78, p. 168 e $\$ 38$, p. 77-79.

${ }^{258}$ Idem, Die Idee der Phänomenologie, p. 35-36.
} 
significação do conhecimento da reflexão!", Husserl responderia com certa dose de vilipêndio: em primeiro lugar, todo aquele que duvida da reflexão só pode exprimir um contra-senso, uma vez que para dela poder duvidar é preciso sobre ela...refletir; em segundo lugar, se até mesmo de Deus, caso desejasse apreender a consciência, era exigido que refletisse, que ouvidos haveria de se dar ao psicólogo? Indubitável, o que a reflexão toma para si é uma doação absoluta, o próprio Ser da consciência: “aqui, como em toda parte, o ceticismo perde sua força por meio do recuo que parte das argumentações verbais em direção à intuição de essência, à intuição originariamente doadora e ao seu direito

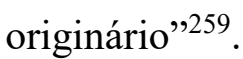

Sabendo-se então que a consciência fenomenológica permanece sempre no interior de uma mesma região e que, por permanecer, doa-se absolutamente a si mesma, nada nos impede de reconhecê-la como absoluta também no sentido de que não carece de "coisa" alguma para existir. É justamente isso que anuncia a famigerada sentença situada no cerne do primeiro livro de Ideias: “o ser imanente é, portanto, indubitável no sentido de ser absoluto que, por princípio, nulla 're' indiget ad existendum" ${ }^{260}$. Mas para onde aponta, exatamente, esta rememoração da fórmula dos Principia? Estaríamos diante da insinuação de um arrependimento e de uma tardia retomada do cartesianismo? Não se trata disso. A retomada do dito de Descartes - que não se dá sem alterações, para deixálo mais ao gosto de Husserl - aí está para nos indicar que a consciência, tal e qual é para a fenomenologia transcendental, se determina a partir da distância abismal que separa seu Ser do Ser do transcendente. Enquanto o mundo carrega consigo a possibilidade ideal de não-Ser, uma vez que a existência da coisa na doação jamais é "necessária" (e sim meramente "casual”), a apreensão da vivência, seja ela qual for, será sempre indubitável nesta volta de si para si, será o encontro do espaço onde se ausenta todo conflito e se afasta toda aparência: "toda coisa dada em carne e osso pode não ser, nenhuma vivência dada em carne e osso pode não ser; isto constitui a lei da essência que define esta necessidade e aquela casualidade" 261 . Donde a constatação husserliana de que a consciência, em sua independência sem precedentes, não apenas é invariavelmente, mas

\footnotetext{
259 “Também Ele [Deus] somente poderia obter um conhecimento de sua consciência e de seu conteúdo de consciência reflexivamente.” Idem, Ideen I, §79, p. 174-175. Cf. também Martin Heidegger, Prolegomena zur Geschichte des Zeitbegriffs, GA 20, §11b, p. 143: "a vivência refletida, que é objeto em uma reflexão, é originariamente dada nela mesma. As vivências, em oposição ao transcendente, estão aí em sentido absoluto, isto é, elas não se apresentam indiretamente, simbolicamente, mas são apreendidas em si mesmas."

${ }^{260}$ Edmund Husserl, Ideen I, \$49, p. 104.

${ }^{261}$ Idem, Ibidem, §46, p. 98.
} 
também é sem que careça de algum outro Ser para assegurá-la. Poder-se-ía muito bem reduzir o mundo das coisas ao nada (Vernichtung der Dingwelt) - ainda assim, sua inexistência, dirá Husserl, sequer afetaria o Ser da consciência. Fato é que, se em algum momento a história da filosofia pregou que as vivências retiravam seu sentido do substrato do mundo, agora a fenomenologia irá dissolver esta falácia ao ensinar que os pólos da relação estavam dispostos de maneira errônea e que é a consciência a despontar como absoluta. Propriamente falando, ela será a "pressuposição de Ser" (Seinsvoraussetzung) segundo a qual todo outro, distinto da consciência ela mesma, estará sob o jugo de seu absolutismo, sendo-lhe sempre relativo e devendo-lhe seu Ser. E a partir daí, qualquer tentativa de atribuir ao mundo o título de absoluto, não passará de ladainha psicologista: “assim, [a fenomenologia] inverte o sentido geral do discurso do ser; o ser, que para nós é o primeiro, é em si o segundo, ou seja, é o que é somente em 'relação' ao primeiro (...) uma realidade absoluta vigora exatamente como um quadrado redondo" ${ }^{262}$. Se os princípios da doutrina fenomenológica sancionam a "destruição da objetividade das coisas" (Destruktion der dinglichen Objektivität), é para afirmar que já não se pode sustentar com direito a res extensa ou a coisa-em-si, mas apenas a "realidade" enquanto constituída e, por isso mesmo, dependente. A única esfera digna da alcunha de "ser absoluto" é, portanto, a consciência que de nada carece para existir e que tudo constitui: “com efeito, não perdemos nada, mas obtivemos todo o Ser absoluto, o qual - retamente compreendido - abriga em si todas as transcendências, constituindo-as em si”’263.

Mas se Husserl faz questão de acentuar que a consciência nulla 're' indiget ad existendum, por sempre bastar a si mesma e permitir a manifestação de todas as coisas, não será surpreendente que ela venha a ser por fim caracterizada como ser puro. E por pureza não se entenderá senão a ausência de qualquer traço de singularidade concreta ou de qualquer vestígio de realidade que possa surgir na descrição das vivências. Daí esta consciência pura ser o contrário mesmo de sua homônima definida pela orientação natural. Afinal, a retórica do psicologismo defendia uma subjetividade que estava desde o início lançada no interior do mundo e era compreendida como um acontecimento real; a decisão que estava na origem do discurso do psicólogo repousava na crença de que a vivência jamais poderia ser tomada por si, mas deveria ser sempre apreendida num ligame indissolúvel com o corpo - que lhe arrasta do pináculo olímpico do transcendental para o

\footnotetext{
${ }^{262}$ Idem, Ibidem, $\$ 50$ e $\$ 55$, p. 106 e 120. Cf. Martin Heidegger, Prolegomena zur Geschichte des Zeitbegriffs, GA 20, §11c, p. 144.

${ }^{263}$ Edmund Husserl, Ideen I, §50, p. 106-107
} 
telúrico do real e lhe insere nos marcos da espaço-temporalidade: "apenas por meio da experiência da relação com o corpo, a consciência torna-se realmente humana e animal, e apenas por isso ela obtém seu lugar no espaço da natureza e no tempo da natureza - o tempo que é fisicamente medido"264. Enquanto "alma", a consciência estará sempre subordinada ao mundo porque um corpo a detém e a retém num laço insolúvel, individualizando-a e levando-a a ser considerada em suas partes reais. E é por isso que desde as Investigações Lógicas Husserl irá recusar qualquer associação da fenomenologia com "teorias anímicas", opondo-se constantemente à descrição tacanha e atrofiada da subjetividade que Descartes oferece nas Meditationes; e é por isso também que se verá, no livro de Ideias, a fenomenologia ser definida - "por mais paradoxal que isso soe" como uma ciência da consciência "sem alma" (seelenlos) porque "sem corpo" (leiblos) e impessoal, "isto é, um fluxo de vivências no qual não se constituem as unidades intencionais de experiência 'corpo', 'alma', 'eu-sujeito empírico', e também assim não teria nenhum indício no sentido psicológico da vivência (como vivência de uma pessoa, de um eu animal) e, em todo caso, nenhuma validade" ${ }^{265}$. Sem qualquer resquício de realidade que lhe pudesse conspurcar a apreensão, a consciência fenomenológica será então a conquista do território do a priori das vivências em sua generalidade, em seu caráter eidético, livre do processo de individuação por não estar agrilhoada ao mundo. $\mathrm{E}$ se é assim, não é sem razão - dirá Husserl - que esta ciência eidética só poderá ser uma ciência das irrealidades, cuja fonte da qual pode emanar sua constituição é a mais pura fantasia: "de todo modo, a liberdade da pesquisa eidética exige aqui necessariamente o operar na fantasia"266. Uma ciência eidética absoluta posta em marcha pela fantasia absoluta - não há nada mais coerente do que isto: quando a redução tudo enclausura em seus parênteses, de modo a evitar a tão prejudicial metábasis, é somente a Fiktion que permitirá cumprir a tarefa com autenticidade e sem recuo dogmático; ela será o "elemento da vida da fenomenologia" (das Lebenselement der Phänomenologie), a responsável por alimentar cuidadosamente a descrição dos "irreais" e por fazê-la alcançar suas "verdades eidéticas eternais" numa pureza absoluta.

Foram então estas determinações do ser absoluto que permitiram à fenomenologia consumar a tarefa fundamental que a filosofia de Descartes se contentava apenas em apontar. Afinal, a se crer piamente nas palavras de Husserl, era graças ao trato de cada

\footnotetext{
${ }^{264}$ Idem, Ibidem, §53, p. 116.

${ }^{265}$ Idem, Ibidem, §54, p. 119.

${ }^{266}$ Idem Ibidem, §70, p. 148.
} 
um destes "sentidos" que se reconhecia a entrada no campo da "verdadeira subjetividade" e, consequentemente, se permitia supor que o "conhecimento" havia sido enfim “conhecido". Mas quanto de verdade poderíamos atribuir a tal juízo husserliano? Em que medida seria possível afirmar que estas "determinações de Ser" refletiam efetivamente o Ser da consciência? Eis aí uma pergunta que Heidegger não tardou em se colocar, e que, aliás, não hesitou em responder negativamente: a doutrina de Husserl - escrevia ele nos Prolegômenos - jamais fora capaz de cumprir a promessa de ofertar o traço mais originário do "Ser do intencional" porque encontrava-se inteiramente satisfeita com a descrição da essência das vivências ("como apreendida, dada, constituinte e ideal"); preferindo recorrer a certas definições, que "a princípio eram estranhas à consciência"267, em momento algum ela se indagou pelo Ser do ente enquanto tal. Fato é que, apesar de todo empenho do primeiro livro de Ideias em circunscrever as ditas Seinsbestimmungen, o ser autêntico ainda lhe faltava completamente. E que não se pense, dirá Heidegger, que esta falta (Versäumnis) consiste numa ocorrência casual, numa espécie de lapso facilmente corrigível no curso da argumentação. Nada disso. A falta é, antes de tudo, o "campo fundamental" (Grundfeld) onde a pesquisa fenomenológica fixa suas raízes, onde a crença num Ser absoluto em suas múltiplas determinações faz com que toda procura pela pergunta (Seinsfrage) e pela resposta seja "em vão"268. Pois se é certo que "a pergunta pelo Ser é ali colocada, e é mesmo respondida" de alguma maneira, Heidegger não deixará de frisar que o encontro com este "Ser", tal como o vê a fenomenologia transcendental, não apenas desloca a questão de seu lugar originário (não a discutindo, unerörtet), como também a situa no interior das fronteiras da própria tradição filosófica ${ }^{269}$. E se é assim, quando observada a partir da "falta fundamental" (fundamentales Versäumnis), a tão celebrada "ruptura" provocada pela fenomenologia torna-se superficial. Mas o que pôde ali permanecer escamoteado, a ponto de impedir a fenomenologia de proferir a autêntica pergunta pelo Ser? O que pôde se esquivar do preceito da exclusão de pressupostos, em curso desde os Prolegômenos à Lógica Pura? Ora, ao supor que a "filosofia poderia ser construída no ar, não carecendo de nada para começar" ${ }^{270}$, e que, com isto, ela estaria livre de todo pré-juízo, Husserl não fora capaz

\footnotetext{
${ }^{267}$ Martin Heidegger, Prolegomena zur Geschichte des Zeitbegriffs, GA 20, §11d, p. 146.

${ }^{268}$ Idem, Ibidem, GA 20, §13, p. 158.

${ }^{269}$ Idem, Ibidem, GA 20, §12, p. 155.

${ }^{270}$ Idem, Ibidem, GA, 20, §14a, p. 187-188. Cf. Edmund Husserl, Cartesianische Meditationen, §34, p. 104: "O tipo geral assim obtido percepção, por assim dizer, flutua no ar - no ar das imaginações (Erdenklichkeiten) absolutamente puras”.
} 
de entrever que o único pressuposto que a eversio jamais poderia excluir do circuito de considerações era...a própria eversio. Quando recuperada como norma, ela de fato afastava o fenomenólogo da interferência das ideias históricas e "ingênuas", mas o fazia com a mesma força com a qual o atava às Meditationes: se Husserl pôde levar a fenomenologia tão longe, dilatando cada vez mais sua "radicalidade", isto somente ocorreu por ter se curvado, desde o início, ao momento fundador da filosofia cartesiana. Deste modo, toda censura dirigida a Descartes não era senão uma prova do respeito que lhe devia ser prestado - o que não deixará de nos lembrar a anedota de Anaxarcos, que ao cair numa vala profunda se aborrecera com Pirro por não o socorrer, e em seguida o louvara por isso, uma vez que concordavam que o filósofo deveria ser indiferente e não ter compaixão por ninguém. Herdar a eversio significava saber - caso nos seja permitido inverter o sentido do aforismo de Guimarães Rosa - que "afastar-se é se aproximar"271.

Deve-se então tudo conceder a Kierkegaard e com ele reconhecer que adotar a “exclusão de pressupostos" como fio condutor da reflexão coloca qualquer filósofo em apuros. Afinal, aquele que a recebia de outrem já não podia afirmar sem sérias consequências: "eu agradeço muito por isso, mas me perdoe que eu agora também duvide da correção desta afirmação"; por mais honesta que pudesse parecer a conclusão, a sentença deixaria transparecer um caráter aporético, no qual o acordo seria "a expressão perfeitamente abstrata de seu desacordo" 272 . Deste modo, não podendo liquidar a noção tão logo fosse obtida de seu "mestre", ao "discípulo" restava apenas aceitá-la e crer em seu sentido - tornando o momento inaugural de toda filosofia "rigorosa" um ato de pura fé. Se é assim, dirá Heidegger, toda aquela querela teórica entre Husserl e Descartes não passava, no fundo, de uma desavença de família, uma vez que a purgação colocada em curso se dava conforme a crença num preceito comum. E sabe-se muito bem para onde esta assunção do "preceito comum" irá conduzir: quando se crê na possibilidade da eversio generalis, ela se torna uma espécie de bússola que aponta fixamente para "a ideia da cientificidade absoluta e rigorosa" ${ }^{273}$. Daí não ser surpreendente que à fenomenologia transcendental falte o Ser autêntico, assim como também faltava à filosofia cartesiana:

\footnotetext{
271 "Sendo que aproximar-se é se afastar". João Guimarães Rosa, Do diário em Paris - III, in: Ave, Palavra, p. 335. Sobre o caso de Anaxarcos, cf. Søren Kierkegaard, Johannes Climacus ou De omnibus dubitandum est, cap. II, §1, p. 65-66.

${ }^{272}$ Søren Kierkegaard, Johannes Climacus ou De omnibus dubitandum est, cap. II, §1, p.66.

${ }^{273}$ Martin Heidegger, Prolegomena zur Geschichte des Zeitbegriffs, GA 20, §13f, p. 180. É este pressuposto que explica o fato de que a "filosofia não é ciência, de não ter conhecido nenhum começo enquanto ciência", e a reivindicação de Husserl de que apenas a fenomenologia seria capaz de suprir esta carência. Cf. Edmund Husserl, Philosophie als strenge Wissenschaft, §4, p. 8.
} 
quando todo o cenário da "preocupação com o conhecimento conhecido" encontra-se dominado pela "preocupação com a formação da ciência" (Sorge der Wissenschaftsausbildung), o conceito de Ser passa a ser compreendido como "ser em sentido do Ser-região para uma ciência" (Sein im Sinne des Region-Seins für Wissenschaft). Por não se originar "do ente mesmo" (aus dem Seienden selbst), e sim de uma concepção de ciência absoluta, as ditas "determinações de Ser" podem tornar manifesta apenas "a região enquanto região, mas não o Ser da consciência mesma", quer dizer, tomam o Ser por "ser verdadeiro" para um conhecimento teórico-científico - ou simplesmente por uma Objektivität sui generis da ciência da consciência, sobreposta ao Ser autêntico e à sua antecedência a todas as possibilidades de descrição científica ${ }^{274}$. E se é assim, pouco importa - assegura Heidegger - o alcance daquela eversio à qual Husserl pretende submeter as Meditationes, pois, ao final, a ideia de eversio permanecerá intacta como "prejuízo" e trará consigo a preocupação com a construção da ciência fundamental. Desde então, se já não é permitido o "retorno às coisas mesmas" sem que isto signifique retornar às coisas "enquanto tema de uma ciência", o princípio da exclusão de pressupostos caducará: a consciência como região de uma ciência absoluta não nasce da pura Fiktion fenomenológica, "mas é a ideia que ocupa a filosofia moderna desde Descartes"; não se responde a pergunta pelo ser porque o cogito cartesiano " não somente não é discutido por Husserl, como também é assumido como óbvio (selbstverständlich übernommen)" ${ }^{275}$.

Tudo se passava então como se um grilhão situado no interior da fenomenologia a atasse à filosofia de Descartes. Um grilhão, a bem dizer, que não poderia ser rompido: se é verdade que a "exclusão de pressupostos" desempenhava um papel fundamental, sem a qual não se tinha o direito de pensar uma ciência absolutamente subjetiva, também o será o fato de que ela era o princípio responsável por assentar a doutrina husserliana no mesmo solo das Meditationes. Eis aí a vertiginosa constatação que Heidegger expunha a

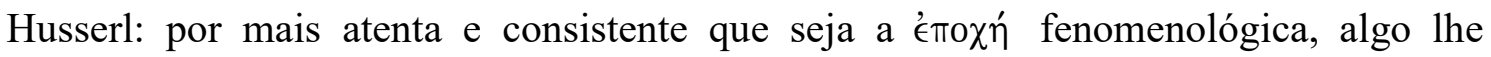
escapará; o conceito de eversio sempre estará ali para profanar a si mesmo, como um pressuposto irredutível que nos rememora a ironia de tentarmos nos afastar de Descartes

\footnotetext{
${ }^{274}$ Martin Heidegger, Prolegomena zur Geschichte des Zeitbegriffs, GA 20, §12 e §13b-§13c, p. 149 e 165 166; Einführung in die phänomenologische Forschung, GA 17, \$48, p. 270. Cf. Marco Antonio Valentim, Heidegger sobre a fenomenologia husserliana: a filosofia transcendental como ontologia, p. 213-238.

${ }^{275}$ Idem, Einführung in die phänomenologische Forschung, GA 17, §§47-48, p. 267-274; Prolegomena zur Geschichte des Zeitbegriffs, GA 20, §11d, p. 147.
} 
por meio de um caminho tipicamente cartesiano. E mais do que isto: era como se este fascínio sub-reptício, que metamorfoseava o anti-cartesianismo em ultra-cartesianismo, não fosse ainda a mais funda chaga na "pura" carne da ciência supostamente rigorosa. Afinal, a fenomenologia transcendental não se vinculava apenas ao cartesianismo em sua preocupação com a "problemática da razão" (Vernunftproblematik), mas se vinculava também, com o cartesianismo, a uma tradição há muito sedimentada na própria filosofia. "Não uma tradição qualquer", é verdade, mas sim um movimento que, embora "se delineasse a partir da urgência das coisas mesmas e de seu tratamento", encontrava sua real condição já perfeitamente descrita no Sofista de Platão:

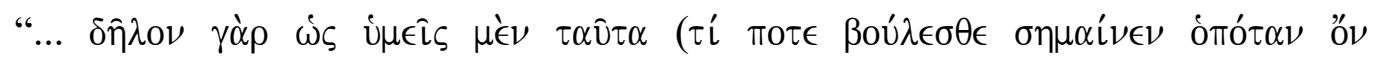

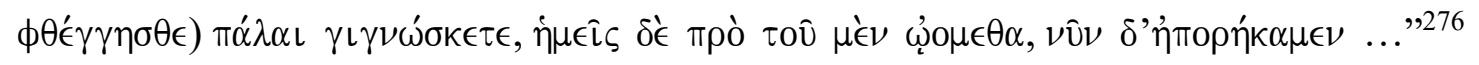

Ora, por "tradição" não se entenderá senão o silêncio sepulcral da história da filosofia em relação à pergunta fundamental, quer dizer, sua condição emudecida "desde Aristóteles que de tão emudecida, já não sabe mais que é muda porque trata constantemente o ser conforme as determinações e perspectivas tradicionais dos gregos" ${ }^{277}$; ela será a falta originária, o "peso e o fardo" que toda a filosofia carrega sob a forma do esquecimento da "pergunta pelo ser" (Seinsfrage). Sendo assim, tratava-se dum ônus que não deixava de recair também sobre os ombros de Husserl, e que o colocava "ontologicamente junto aos antigos"278: originando-se de uma eversio auto-sabotadora em seu estado de insuspeição, a fenomenologia estava fadada a conviver com aquela sombra de Descartes que a arrastava silenciosamente ao seio de uma tradição tão antiga quanto a própria filosofia. Donde a conclusão heideggeriana: sem retornar ao Ser autêntico enquanto "a coisa mesma", "a fenomenologia em sua tarefa fundamental da determinação de seu

\footnotetext{
276 “...pois é evidente que sabeis o que quereis significar quando dizeis a palavra "ser"; nós outrora soubemos, mas agora encontramo-nos em aporia..." Platão, Sophista, 244a. Cf. Martin Heidegger, Sein und Zeit, p. 1; Prolegomena zur Geschichte des Zeitbegriffs, GA 20, §13f, p. 179-180.

${ }^{277}$ Martin Heidegger, Prolegomena zur Geschichte des Zeitbegriffs, GA 20, §13f, p. 180.

${ }^{278}$ Idem, Ibidem, $\$ 13 \mathrm{c}$, p. 170.
} 
campo mais próprio será unphänomenologisch, isto é, pretensamente fenomenológica"279.

${ }^{279}$ Idem, Ibidem, §13f, p. 178. 


\title{
Capítulo 3
}

\section{Das Dasein: a pergunta pelo Ser e a analítica existencial}

\author{
“Et vae tacentibus de te, quoniam loquaces muti sunt”. Santo \\ Agostinho, Confessiones, I, 4. \\ "Iube, quaeso, atque impera quicquid vis, sed sana et aperi \\ aures meas, quibus voces tuas audiam”. Santo Agostinho, \\ Soliloquia, I, 5.
}

\section{I - A concepção tradicional de Ser}

Quando Heidegger nos anunciava sua constatação pérfida de que a fenomenologia husserliana não passava de um arcabouço doutrinário "pretensamente fenomenológico", qual razão parecia motivar este juízo? O que havia de tão suspeito na obra do mestre que teria levado o discípulo a talvez proferir um exagero ou mesmo um paradoxo? Ora, a causa da represália ostentava um teor demasiadamente grave para que se esperasse algum decoro de sua exposição: nas páginas das preleções de Marburg, Husserl não figurava como nada menos que um fedífrago, acusado de atraiçoar sua própria causa mediante o descumprimento de sua palavra de ordem. É certo que Heidegger não deixou de prestar honestos elogios ao desenvolvimento de alguns temas fenomenológicos (como as noções de intencionalidade ou de intuição categorial), mas mesmo este reconhecimento parecia ser de pouquíssima monta em comparação com o fato de que a fenomenologia, embora o proclamasse, em momento algum havia "retornado à coisa ela mesma", quer dizer, jamais havia colocado autenticamente "a pergunta pelo Ser". Com efeito, os ganhos pareciam ser bastante exíguos em face de tal privação; eles, definitivamente, não suplantavam a falta. E esta falta, como bem se sabe, tinha sua origem assegurada pela presença muito marcante de uma tese seiscentista, oriunda das Meditationes. É que Husserl não pressentiu, verdadeiramente, como a herança da eversio (enquanto momento inaugural de uma "ciência rigorosa") lhe colocaria mais entraves do que lhe traria proveitos. A ideia de uma "exclusão de pressupostos", a princípio tão engenhosa para a obtenção da almejada pureza, revelar-se-ía um delírio de presunção do filósofo cartesiano: é verdade

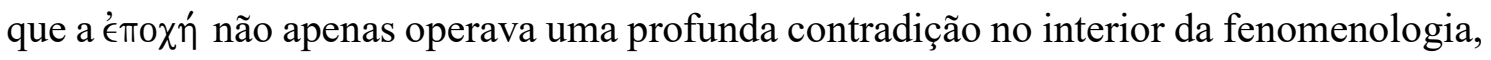


já que ela mesma, ao surgir como um pressuposto, fazia do impulso a própria derrocada; mas ela também ía além e fornecia de bom grado ao fenomenólogo uma suposta "ontologia", cuja principal característica consistia em incutir no "sujeito absoluto e idealizado" aqueles "restos de teologia cristã" ${ }^{280}$. Daí que "a elaboração da consciência pura como campo temático da fenomenologia não era obtida fenomenologicamente num retorno às coisas mesmas, mas no retorno à uma ideia tradicional da filosofia" ${ }^{281}$. Assim, Husserl estaria mais próximo de Descartes do que gostaria de admitir - não porque fossem lembrados pela ruptura provocada por seu filosofar, e sim porque a "novidade" proferida aparecia como "algo novo" (etwas Neues) somente em seu "aspecto externo" (außerlicher Aspekt). Observado de perto, o "inédito" cenário filosófico que ambos se gabavam de delinear não passava da reafirmação da tese fundamental da vetusta ontologia grega. As meditações, fossem elas de filosofia primeira ou cartesianas, eram míopes à sua própria essência, pois ignoravam que sua "preocupação com o conhecimento conhecido" ecoava "no modo da absoluta primazia do $\theta \epsilon \omega \rho \in \hat{\imath} \nu "$ (apreensão teórica, theoretische Auffassung) e de sua determinação do Ser do ente como substância. Pobre Descartes, lamentará Heidegger: pensava estar livre de todos os pressupostos quando, na realidade, era incapaz de colocar a perguntar pelo Ser porque permanecia ontologicamente junto aos antigos. E pobre Husserl: ao crer na promessa da eversio, assumia secretamente uma ontologia que o levava a conceber o "Ser dos atos desde o princípio de maneira teórico-dogmática enquanto Ser no sentido da realidade da natureza". ${ }^{282}$

Isto significa que todo o mal provém desta aceitação silenciosa da metafísica clássica? Sem dúvida. Se há algum impedimento em nossa possibilidade de uma verdadeira apreensão do Ser, ele se deve àquela interpretação do Ser do ente "como a realidade do real, como o ser-simplesmente-dado (Vorhandensein)". Que sejam então folheados os tratados gregos sobre a questão, recomenda Heidegger: ali observaremos como o "ente ontologicamente exemplar (isto é, o ente a partir do qual é lido o Ser e seu sentido)" não é outro senão "a natureza em seu sentido mais amplo" - aquilo que graças a retórica kantiana se convencionou chamar "Objekte"283. Bastaria, assim, percorrer as

\footnotetext{
${ }^{280}$ Martin Heidegger, Sein und Zeit, §44c, p. 229.

${ }^{281}$ Idem, Prolegomena zur Geschichte des Zeitbegriffs, GA 20, §11d, p. 147.

282 "Na consideração e na formação da consciência pura, é também salientado, pura e simplesmente, o conteúdo do Was, sem perguntar pelo ser dos atos no sentido de sua existência (...) Mostrar-se-á que esta incompreensão reina (herrscht) na fenomenologia e reina com base na dominação (Herrschaft) da tradição". Idem, Ibidem, GA 20, §12, p. 152 e 157; Einführung in die phänomenologische Forschung, GA 17, §19, p.115.

${ }^{283}$ Idem, Die Grundprobleme der Phänomenologie, GA 24, §13a, p. 173-174.
} 
páginas de Aristóteles para que tivéssemos diante dos olhos o conceito de Ser que provocou o extravio de toda a história da filosofia no que diz respeito à pergunta fundamental. Contudo, quão exacerbada não seria esta leitura? Vá lá que os gregos estivessem "orientados ao ente simplesmente dado" e o tomassem pelo Ser. Mas acreditar que esta interpretação se estenda também a Descartes? Como crer na validade desta tese se desde muito cedo aprendemos a identificar em seu pensamento uma "reviravolta total" (totale Umwendung) da questão filosófica, responsável por situar o eu-sujeito no posto de lisonja que outrora era do objeto? Diante disso, talvez fosse melhor supor que este ponto de torção - que marca a passagem para a filosofia moderna - apresenta um novo modo de ser do ente graças ao olhar voltado agora para o eu; talvez devêssemos também esperar que a escolha de um novo "ente exemplar" e que a interpretação do conceito de sujeito em seu modo de ser representassem uma nova forma de observar a problemática ontológica... "Mas este certamente não é o caso"284. Aos olhos de Heidegger, esta "ruptura" se reduz à mera convicção escolar. Afinal, dos muitos e distintos caminhos que Descartes poderia trilhar diante da "já preparada reviravolta", optara por aquele que não somente se furtava à pergunta pelo Ser do sujeito, mas que também o compreendia conforme o conceito de Ser e as categorias tão caras aos pensadores antigos e medievais. "Por meio desta reviravolta, deste novo começo supostamente crítico da filosofia proposto por Descartes, assume-se a ontologia tradicional" ${ }^{285}$. Desde então, já não se trata de dizer que os antigos problemas metafísicos eram investigados à margem da nova problemática, mas sim de reconhecer que os "novos" problemas ainda repousavam sobre um antigo fundamento. Rigorosamente falando, acreditar que aí havia alguma "novidade ontológica" era celebrar a vana gloria: a "reviravolta" era apenas um termo esvaziado de sentido e as Meditationes, sempre rememoradas por sua eversio generalis, tinham suas teses escritas de acordo com a mais erudita gramática do grego clássico. E é por isso que esta figura do "insígne sujeito" não poderá ser entendida como mais do que uma simples

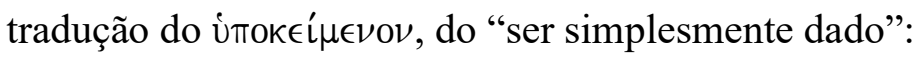

"O conceito de sujeito no sentido da subjetividade, da ipseidade (Ichheit), é ontologicamente ligado do modo mais estrito à categoria apofântico-formal de subjectum, de ітокєі́ $\mu \in \mathrm{\nu} \nu$ - no qual, a princípio, nada de ipseidade ali se encontra. Ao

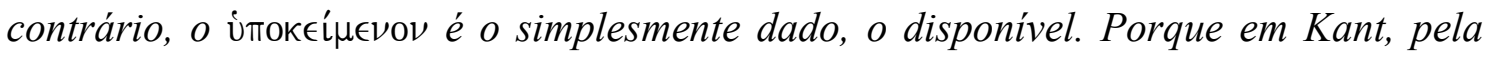

\footnotetext{
${ }^{284}$ Idem, Ibidem, GA 24, §13a, p. 174.

${ }^{285}$ Idem, Ibidem, p. 175.
} 
primeira vez e explicitamente (ainda que em Descartes e antes de tudo em Leibniz tenha sido já prefigurado), o eu é o sujeito próprio (dito de maneira grega, a própria

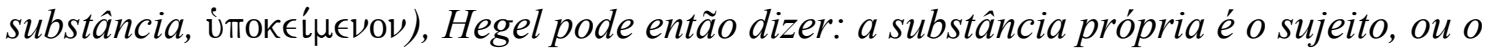
sentido próprio da substancialidade é a subjetividade" 286 .

Se há páginas onde esta ligação essencial entre os termos pode ser observada, elas certamente se encontram nos Principia Philosophiae. É ali que Descartes, ao se perguntar pelo sentido do Ser do ente, nos ofertará uma resposta que em nada é devedora do jargão da tradição: o Ser compreende-se como substantia. Todavia, não seria esta uma aproximação meramente nominal? Longe disso, protesta Heidegger. Quando nos fala da substância, Descartes não apenas emula o conceito e a expressão, mas remete também ao ente "segundo a matéria dos escolásticos e, com isto, à maneira fundamentalmente grega de perguntar"; ele deixa claro que o Ser não pode ser outra coisa senão o ente cujo modo de ser é a "substancialidade" enquanto "simplesmente dada" (Vorhandenheit), a oủoí $\alpha{ }^{287}$. Aliás, a passagem que dá testemunho fidedigno desta equivalência é bastante conhecida: "por substância não podemos entender senão a coisa que existe, a fim de que não careça de nenhuma outra coisa para existir" (per substantiam nihil aliud intelligere possumus, quam rem quae ita existit, ut nulla alia re indigeat ad existendum). Mais uma vez é ela a nos rememorar que o Ser repousa, antes de tudo, naquele ente que não carece de nenhum outro ente para existir, e que nos responderá quando indagarmos pela substancialidade da substância ou pela realitas da res. Em bom latim, o Ser é aquilo que se manifesta como o ens perfectissimum - um outro nome para Deus, este nobre "título para o ente que nos encontra no sentido do conceito de Ser enquanto simplesmente dado" 288 .

Mas isto, evidentemente, não é tudo. Se Descartes reconhece, num primeiro momento, que a substância não experimenta nenhum tipo de carência, ele não deixará de assinalar que ela é também a causa de todas as outras coisas: a afirmação de que Deus não carece de nada para existir será sempre sucedida de uma outra, ensinando-nos que os demais entes somente podem existir por obra e graça de uma "união" ou "encontro", de um concursus Dei; algo pode ser determinado como "simplesmente dado" (Vorhandensein) apenas na medida em que se compreende como "ser-simplesmente-

\footnotetext{
${ }^{286}$ Idem, Ibidem, GA 24, 13b $\alpha$, p. 178-179. Cf. Alain de Libera, Sujet insigne et Ich-Satz: deux lectures heideggériennes de Descartes, p. 85-101.

${ }^{287}$ Idem, Prolegomena zur Geschichte des Zeitbegriffs, GA 20, §22, p. 232; Sein und Zeit, §20, p. 92.

${ }^{288}$ Idem, Ibidem, GA 20, §22, p. 233. “....substantia quae nulla plane re indigeat, unica tantum potest intelligi, nempe Deus”. René Descartes, Principia Philosophiae, I, §51, p. 24.
} 
dado-com" (Mitvorhandensein) Deus. Sendo Ele o primeiro, figurará como creator; tudo que daí se segue, deverá ser entendido como creatum. Mas diante disso - talvez questione algum leitor apressado - o que dizer das demais substâncias nomeadas por Descartes? Se também elas são substâncias, por que não reconhecemos na substantia corporea e na substantia cogitans a mesma potência criadora? Se todas caem "sob este conceito comum" (sub hoc communi conceptu), por qual motivo haveríamos de dintiguí-las? Ora, perguntas deste gênero só teriam cabimento para aquele que ignora as lições do opúsculo aristotélico sobre as Categorias. A confusão provocada por esta leitura estaria em supor que Deus e as res cogitans e extensa, por partilharem da denominação de "substância", são sinônimos. Para que o fossem, deveriam compartir a determinação de sua essência, tal como compartem seu nome:

“É dito 'sinônimo' aquilo que tem nome comum e a mesma definição acerca do nome (...)" 289 .

$\mathrm{Na}$ verdade, quando nos permitimos atribuir a cada um desses entes o nome de "substância", é sempre sob a condição de que sejam homônimos:

"É dito 'homônimo' aquilo que tem nome comum e a definição diferente acerca do nome (...)" ${ }^{, 290}$.

Apesar de nos referirmos a tais substâncias por meio de um nome comum, não podemos esperar que por esta razão haja uma equivalência de seu significado. Pode-se muito bem dizer que "Deus é" ou que o "mundo é" sem que, sob nenhuma hipótese, o termo "é" seja enunciado com o mesmo sentido: não se pode elevar as coisas criadas à condição do criador, nem reduzí-lo à situação das criaturas. Encontrar aí qualquer relação de sinonímia apenas nos diz o quanto ignoramos a infinita diferença que existe entre os modos de Ser desses entes. Daí a insistência de Descartes em enunciar que "o nome substância não convém a Deus e àquelas [criaturas] de modo unívoco, como se costuma dizer nas escolas; isto é, nenhuma significação deste nome - que a Deus e às criaturas é comum - pode ser compreendida de modo distinto" (...nomen substantiae non convenit Deo et illis univoce, ut dici solet in Scholis, hoc est, nulla eius nominis significatio potest distincte intelligi,

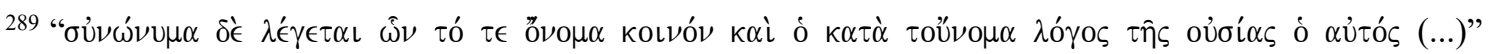
Aristóteles, Categorias, I, 1a, p. 12.

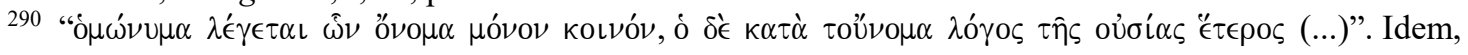
Ibidem.
} 
quae Deo et creaturis sit communis) ${ }^{291}$. Entretanto, o que nos autorizaria a estender à res cogitans e à res extensa um nome que, rigorosamente, deveria ser atribuído apenas a Deus? A resposta é simples: as substantiae creatae podem ser assim chamadas por analogia. Que Deus seja o ente que não manifesta nenhuma carência e que os demais entes necessitem Dele para poder ser, é algo que ninguém há de duvidar. Acontece que, no interior da criação, as substâncias corpórea e cogitante assumem certa primazia: elas não carecem de nenhum outro ente, mas "são coisas que carecem somente da união com Deus para existir" (...sint res, quae solo Dei concursu egent ad existendum); enquanto os entes se relacionam indiretamente com sua causa última de ordem divina, a mente e o mundo o fazem sem mediadores. Na esfera das coisas criadas, não carecem de absolutamente nada para existir. E é justamente por este seu traço de unbedürftig neste âmbito específico que podemos nos dirigir a elas como "substâncias": substantiae finitae, dependentes apenas da substantia infinita de Deus.

Contudo, entender esse desdobramento ainda não nos confere uma apreensão do ente substancial, confessa Descartes. Sei que existe, dirá ele, mas me escapa por completo o que é propriamente. Que a coisa exista, simplesmente não nos afeta em nada por si só: “...quod sit res existens, quia hoc solum per se nos non afficit" ${ }^{292}$. E a ausência da afecção não resultará senão na confirmação de que a via primária de acesso ao Ser deste ente encontra-se definitivamente obstruída à finitude de nossa razão. Caímos então em aporia? De maneira nenhuma, pois facilmente somos capazes de reconhecer (facile agnoscamus) a substância devido a qualquer um de seus atributos: se é próprio das "coisas que são" possuir qualidades (e próprio do "nada" não as possuir), podemos apreender as propriedades da res uma vez que admitimos sua existência. Mas em face desta constatação, acrescenta Descartes, conservemos um certo cuidado: não é porque a substância se faz notar por qualquer um de seus atributos que sua essência emana indistintamente de cada um deles. Dentre todas as suas propriedades, haverá sempre uma a figurar como a principal (praecipua proprietas) - à qual todas as outras estarão remetidas. Caberá ao agudo engenho do filósofo identificá-la em seu Was ("falando de

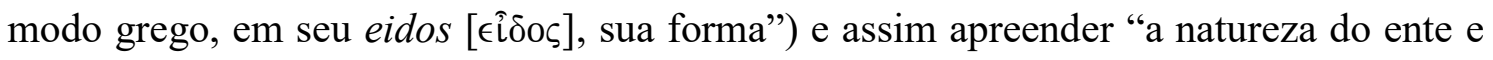
seu Ser" 293 .

\footnotetext{
${ }^{291}$ René Descartes, Principia Philosophiae, I, §51, p. 24.

${ }^{292}$ Idem, Ibidem, I, §52, p. 25.

${ }^{293}$ Martin Heidegger, Prolegomena zur Geschichte des Zeitbegriffs, GA 20, §22, p. 236-237.
} 
Seria então esse trajeto de determinação ontológica, que nos força (por falta de uma afecção originária) a ir do atributo à substância, uma boa nova filosófica transmitida pelos Principia? Nada poderia estar mais distante da verdade. E o que a verve heideggeriana irá mostrar é exatamente o contrário de qualquer convicção que julga encontrar aí algum vulto de originalidade na caracterização do Ser. "Esta proposição característica, de que não experimentamos o Ser per se no ente, é talvez - sem que Descartes o saiba, e que Kant talvez também o compreenda definitivamente em sua tese - a mais nítida fixação do Ser do ente, em seu sentido formal, que nós denominamos 'mundo' - a saber, que não somos afetados pelo Ser do mundo enquanto tal" ${ }^{\text {"294 }}$. Ora, não é por acaso que a descrição da substância corpórea soa como a fiel tradução latina de uma tese originariamente grega. Como de costume, quando Descartes se pergunta qual seria o atributo fundamental a nos fornecer a essência da res corporea, a resposta é desconcertantemente direta: "certamente a extensão (em comprimento, largura e profundidade) constitui a natureza da substância corpórea" (nempe extensio in longum, latum et profundum, substantiae corporeae naturam constituit) ${ }^{295}$. É verdade que podemos distinguir nos corpos uma série de qualidades que nos parecem essenciais: o peso, a cor, a dureza, o movimento... Mas nenhuma delas, seja qual for a perspectiva de consideração, aparecerá verdadeiramente como a propriedade primeira, sob a qual depositam-se todas as demais. Subtraiam-nas todas ou modifiquem-nas ao sabor da boa fortuna, desafia Descartes: transformem sua figura, mudem sua cor, alterem seu movimento - a matéria corpórea sempre estará ali, conservada em sua extensão. Pouco importa quantas sejam as variações às quais a submetemos: somente a extensão "permanece ela mesma íntegra" (ipsa integra remanente). Conservando-se enquanto reúne em si as modificações (capax mutationum remanere), a natureza do corpo dependerá, inegavelmente, desta sua característica, "pois tudo aquilo que lhe pode ser atribuído, pressupõe a extensão" (nam omne aliud quod corpori tribui potest, extensionem

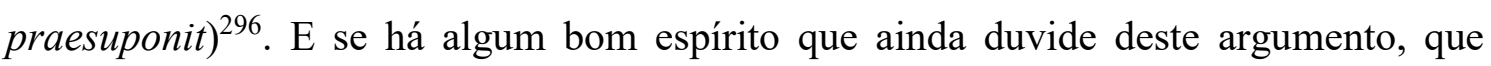
aproxime um pedaço de cera de uma chama - aí ele encontrará sua prova.

Heidegger parece ter então boa razão para suspeitar da disseminada opinião acerca do ineditismo ontológico da tese cartesiana. Afinal, a proximidade da passagem dos

\footnotetext{
294 Idem, Ibidem.

${ }^{295}$ René Descartes, Principia Philosophiae, I, §53, p. 25.

${ }^{296}$ Idem, Ibidem, I, §53, p. 25; II, §4, p. 42. Martin Heidegger, Sein und Zeit, §§19-20, p. 89-95. Cf. JeanLuc Marion, The Ego and Dasein, in: Reduction and Givenness, p. 88-92.
} 
Principia com as palavras de Aristóteles é tão impressionante, diz ele, que é surpreendente como até este momento não se notou que as "distintas" determinações ontológicas não passam de uma e mesma coisa:

“A substância, por receber ela mesma os contrários, é dita receptáculo dos contrários. De fato, recebe a doença e a saúde, a alvura e a negritude; e recebendo cada uma destas coisas, é dita ser receptáculo dos contrários. Assim, é próprio da substância, sendo idêntica e numericamente una, ser receptáculo dos contrários"297.

"Receptáculo dos contrários, permanecendo idêntico e numericamente uno", ou remanens capax mutationum: seja qual for a fórmula de preferência, fato é que Descartes, em momento algum, ofereceu uma determinação original da substância do mundo, mas prescreveu-lhe a helênica ideia de Ser, definindo-a como o ente dado de maneira simples e permanente (ständige Vorhandenheit). E o desdobramento desta prescrição não deixa de ser irônico. Certamente seria custoso ao filósofo de linhagem cartesiana acreditar que uma tal transposição tivesse escapado - por mais furtiva que fosse - ao rigor do Método. E ele teria razão em pensar desta maneira, pois, de fato, ela não escapou. O problema é que, contrariando amargamente suas expectativas, as exigências metódicas não vão excluir essa ontologia do circuito de considerações, mas corroborarão a necessidade de sua prévia presença e de sua assimilação. Ora, o que mais seria a intellectio senão o emblema desta comprovação? Se Descartes insiste que no conhecimento de origem físico-matemática repousa o único modo de acesso autêntico ao ente (já que os sentidos se restringem a assinalar diversidades e por isso "não fornecem, para falar claramente, nenhum conhecimento" ${ }^{298}$ ), é porque somente aí este ente mesmo será dado na posse de seu Ser, a certitudo. Enquanto bem discernido (certum), livre de todo resquício dubitável, o ente "sempre é o que é"; a despeito de todas as variações, terá o caráter de uma “constante permanência" (der ständige Verbleib). Neste sentido, observa Heidegger, não é por apoiar-se na estimada ciência matemática que o Ser do mundo irá se determinar como outrora se determinava; ao contrário, é por pressupor esta orientação ontológica do Ser como "constância do simplesmente dado" (ständige Vorhandenheit) que o conhecimento matemático - por obter este objeto de maneira excepcional - terá seu

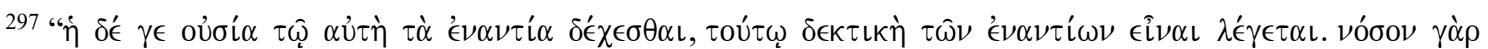

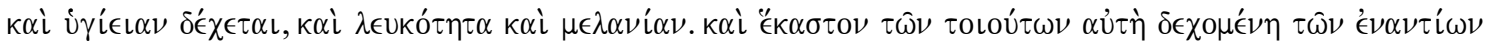

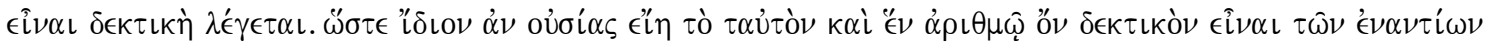

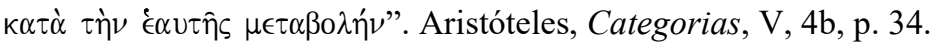

${ }^{298}$ Gérard Lebrun, A noção de semelhança de Descartes a Leibniz, in: A filosofia e sua história, p. 435.
} 
primado reconhecido. "Sob a ininterrupta predominância da ontologia tradicional decidese, desde o princípio, sobre o modo de acesso autêntico do próprio ente" ${ }^{\text {"299 }}$. O que regula o modo de acesso ao ente e possibilita sua apreensão como uma determinada região ôntica é, sem dúvida, a antiga ideia de Ser.

Esta tese, a princípio, bem poderia aturdir algum cartesiano incauto, ainda crente na pureza da eversio. No entanto, refletindo minimamente sobre a questão, ele retrucaria: concedamos, por um momento, que a res extensa talvez comungue com a definição clássica de substância, que possuam o mesmo modo de Ser; contudo, o que também nos autorizaria a proferir um tal sacrilégio sobre a res cogitans? Quanta leviandade não haveria em supor que o ponto arquimediano se define da mesma forma que o mundo? Basta que se leia a célebre sinopse da segunda meditação: podemos conceber de maneira clara e distinta duas substâncias diversas, mente e corpo, "que realmente são distintas uma da outra (...substantias realiter a se mutuo distinctas) - tão distintas que "de algum modo são também reconhecidas como contrárias" (...etiam quodammodo contrariae agnoscantur). Diante disso, como continuar sustentando que a ontologia antiga ainda determina a essência do sujeito? Ao que Heidegger prontamente responderia: que se leia a sinopse até o fim, pois assim se verá quanto esta cisão é aparente! Não se pode negar que ali a intenção de Descartes consiste em diferenciar a natureza das substâncias. Mas no curso da exposição tudo se passa como se a descrição fosse completamente contraproducente, uma vez que substantia pura da mente se define, malgrado sua tentativa de afastamento, tal como a substância corpórea - quer dizer, ela permanece a mesma em face de todos os acidentes que a afetam, capax mutationum remanet:

"Ainda que todos os seus acidentes se modifiquem - que entenda outras coisas, queira outras, sinta outras etc. - nem por isso a própria mente torna-se uma outra"300.

Noutras palavras, o Ser da mens sive animus sive intellectus jamais fora propriamente obtido por Descartes. É que o fascínio exercido pela descoberta do cogito o impediu de voltar a visada ao sum: ao invés de colocar a pergunta pelo autêntico sentido do esse (Ser) do cogitare, contentou-se com um "reflexo ontológico da compreensão do mundo" (die ontologische Rückstrahlung des Weltverständnisses), entendendo-o ao gosto da

\footnotetext{
299 “Ele [Descartes] consolidou a opinião de que o conhecer ôntico, supostamente o mais rigoroso, é também o possível acesso ao Ser primário do ente descoberto em tal conhecimento". Martin Heidegger, Sein und Zeit, §21, p. 96 e 100.

300 "Etsi enim omnia eius accidentia mutentur, ut quod alias res intelligat, alias velit, alias sentiat, et cetera, non idcirco ipsa mens alia evadit”. René Descartes, Meditationes, Med. II, Synopsis, p. 36-38.
} 
metafísica grega. "Deixa-se completamente indiscutido o sum, embora ele seja proposto de maneira tão originária quanto o cogito"301. Por estar fora do lugar que lhe é de direito (un-er-örtert), a res cogitans era ontologicamente apreendida como a res extensa, revelando que uma primazia do modo de Ser próprio do sujeito se reduzia à mera fabulação.

É assim que Descartes acreditou ter feito muito, quando na verdade apenas reproduziu o conceito aristotélico de substância e o circunscreveu ao conhecimento de uma região objetiva. Estranha situação, pois, a desta filosofia da eversio: ela sequer suspeitou quão tradicionalmente se comportava em sua compreensão do conceito de Ser. Mas ainda mais estranha, dirá Heidegger, a situação na qual nos aparecia a fenomenologia: embora Husserl tencionasse levar a bom termo aquela ideia de uma purgação radical, ele parecia ignorar completamente que o preceito da exclusão de pressupostos o faria percorrer um caminho outrora já trilhado. Curiosamente, todos os seus esforços para assegurar a pureza da disciplina revelavam-se, desde o início, tão bem sucedidos quanto a tarefa de Sísifo de empurrar sua rocha montanha acima; vê-lo anunciar a expulsão das transcêndencias do circuito de consideração era como observar o prelúdio da catástrofe integral da promessa do "retorno às coisas mesmas" no exato momento de

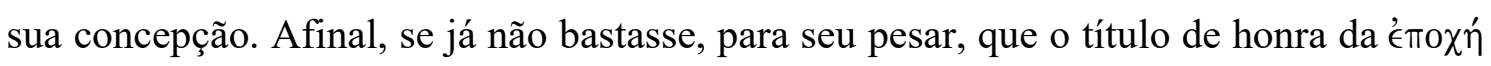
não passava de uma marca de debilidade (sempre configurando um impedimento a si mesma), esta prescrição de semblante cartesiano ainda viria a impregnar o pensamento do fenomenólogo com outros pré-juízos. Que exemplo melhor haveria de ser dado senão o notório fato de que a necessidade de uma eversio pressupunha a "ideia vazia e fantástica de certeza e evidência"? ${ }^{302}$ Ideia danosa, pois graças a ela permitia-se assumir o domínio do cogito como uma obviedade (selbstverständlich ubernommen) e tomá-lo de antemão como o ente cujo modo de Ser é o Sich-mit-haben, quer dizer, o ente sempre voltado para si mesmo na reflexão - a consciência pura. Ora, era justamente sobre isto que versavam as inscrições estampadas no umbral da fenomenologia transcendental:

"Carece-se de uma ciência do ente em sentido absoluto (...vom Seienden im absoluten Sinn) (...) Toda vivência intelectiva e toda vivência em geral, enquanto são consumadas, podem ser objeto de uma intuição e de uma apreensão puras, e nesta

\footnotetext{
${ }^{301}$ Martin Heidegger, Sein und Zeit, $\S 5$ e $§ 10$, p. 16 e 46. "O sentido do sum é esvaziado no sentido do seralgo ontológico-formal”. Idem, Einführung in die phänomenologische Forschung, GA 17, §44, p. 250.

${ }^{302}$ Idem, Einführung in die phänomenologische Forschung, GA 17, §3, p. 43.
} 
intuição são doações absolutas. São dadas como um ente, como um 'isto-ai', do qual não há sentido em duvidar do Ser",303.

Desde o início, portanto, os parênteses mostravam-se demasiadamente porosos e o abalo provocado pelo anúncio de "novo" começo era meramente aparente. É verdade que Husserl jamais se convenceu daquela "tranquilidade prévia" (Vorberuhigung) ofertada por um devoto certum qua bonum, mas nem por isso deixou de acolher a mesma máscara de Descartes ao trazer a vertente transcendental de sua fenomenologia ao centro do proscênio. Larvatus prodeo: "por meio deste mascaramento (Maskierung), a preocupação desloca-se para onde ela quiser" ${ }^{304}$. E para onde ela desejava caminhar? Ignorando o "apelo da fenomenologia" (Ruf der Phänomenologie), a preocupação com o conhecimento conhecido rumava na direção oposta à "coisa mesma"; conservadora em suas pretensões, ela elegia a via daquele ente cuja característica fundamental consiste em ser "a região possível de uma ciência". Mas não nos enganemos: ainda se trata da objetividade oriunda do mundo grego - embora não seja ela entendida somente como um conhecimento teórico, mas teórico-científico. E isto quer dizer que ali, a ocupar o lugar do Ser, encontrava-se o ente enquanto uma "objetividade científica possível": "não se pergunta pelo Ser específico da consciência, das vivências, mas por um ser-objeto por excelência para uma ciência objetiva da consciência" ${ }^{305}$. Que a fenomenologia então "avaçasse mascarada", não significava outra coisa senão o velamento da autêntica pergunta pelo Ser e sua substituição por uma preocupação com a "formação da ciência" (Wissenschaftausbildung). O que não deve causar nenhum espanto no bom leitor, considerando que nada menos se esperaria de uma filosofia da eversio. Este era, na verdade, seu curso natural. Por isso, se Husserl em momento algum colocou a pergunta pelo Ser, foi porque respeitou o pressuposto de obter, antes de tudo, "uma região material para a elaboração científica possível"306. Para ele, longe de representar o que havia de "primeiro", o Ser cedia lugar à "ideia de uma ciência absoluta - e esta ideia de que a

\footnotetext{
${ }^{303}$ Edmund Husserl, Die Idee der Phänomenologie, I e II, p. 22-23 e 31.

${ }^{304}$ Martin Heidegger, Einführung in die phänomenologische Forschung, GA 17, §50a, p. 281. René Descartes, Cogitationes Privatae, p. 190: "Ut comoedi, moniti ut ne in fronte appareat pudor, personam induunt: sic ego, hoc mundi theatrum conscensurus, in quo hactenus spectator exstiti, larvatus prodeo". Cf. Christophe Perrin, Entendre la métaphysique. Les significations de la pensée de Descartes dans l'oeuvre de Heidegger, p. 106-107.

${ }^{305}$ Martin Heidegger, Prolegomena zur Geschichte des Zeitbegriffs, GA 20, §13c, p. 165.

${ }^{306}$ Idem, Einführung in die phänomenologische Forschung, GA 17, §47c, p. 269.
} 
consciência deve ser a região de uma ciência absoluta não é simplesmente inventada, mas é a ideia que ocupa a filosofia moderna desde Descartes"307.

Assim é que a filosofia de Husserl se mostrava, aos olhos de Heidegger, tão "tradicional" quanto a história que outrora ela decidira condenar. Quando se ouvia com atenção, podia-se perceber como a língua ontológica falada nas Meditationes era exatamente a mesma de Ideias I: tanto lá quanto cá, a Sache selbst estava esvaziada de seu sentido originário, sendo entendida como região-tema de uma ciência; tanto lá quanto cá, o Ser da consciência refletia dogmaticamente o Ser da realidade da natureza e fazia com que "o ente fosse exemplificado como o ente realmente dado qua coisa" 308 . E se essa leitura das obras de Husserl sugeria que ele cometera o mesmo "delito" de Descartes, recorrerendo silenciosamente à noção de substância, era porque reconhecia ali uma mesma inabilidade em equilibrar os pratos da balança. Ora, desde que Descartes instituira sua proposição "cogito, ergo sum", as meditações filosóficas posteriores sempre fizeram questão de professar sua predileção pelo ego, abandonando o sum em sua própria indeterminação. Encantadas com os volteios da subjetividade, as filosofias da IchMetaphysik e do idealismo-egóico carregaram excessivamente nas tintas com as quais delinearam este ego e, por esta razão, acabaram por borrar a questão verdadeiramente necessária, "a pergunta pelo sentido do 'sou'"309. Protagonismo indevido do cogito? Sem dúvida - e o fenomenólogo saberá acentuá-lo como ninguém. Quando Husserl afirmava em seus seminários que "se Descartes tivesse se mantido na segunda meditação, teria chegado à fenomenologia" 310 , era para nos lembrar com este pseudo-elogio que toda a ausência de rigor da teoria do conhecimento resultava da decisão errônea de termos deixado um domínio do qual jamais deveríamos ter saído. Pois, se é verdade que a clara et distincta perceptio do ego nos apresentava uma paisagem totalmente nova, não é menos certo que esta descoberta permanecia, de maneira muito contraditória, como uma obscura espelunca. A inescrupulosa transição para a terceira meditação transformava a "grande descoberta" num simples apontamento, deixando todo o trabalho ainda por fazer. Daí a fenomenologia voluntariar-se a este labor hercúleo de remediar todas as mazelas teóricas provenientes de uma ausência que vigorava até então insuspeita: ela assumia o compromisso fundamental e dedicava-se à "tarefa infinita” de descrever sistematicamente

\footnotetext{
${ }^{307}$ Idem, Prolegomena zur Geschichte des Zeitbegriffs, GA 20, §11d, p. 147.

${ }^{308}$ Idem, Einführung in die phänomenologische Forschung, GA 17, §48a, p. 272.

${ }^{309}$ Idem, Phänomenologische Interpretationen zu Aristoteles, GA 61, Anhang I, p. 173.

${ }^{310}$ Idem, Einführung in die phänomenologische Forschung, GA 17, §47c, p. 268.
} 
esse recôndito subjetivo. Mas tanta atenção devotada ao ego - afirma Heidegger - tinha seu preço. Estando obsessivamente empenhada em lançar alguma luz ao domínio do cogito, a ciência rigorosa tratava o sum com a mais absoluta indiferença. E por não o ter jamais questionado, a consciência fenomenológica não possuía um sentido de Ser autêntico, mas era entendida, também ela, como res, partilhando com o mundo seu modo de Ser "formalmente objetivo" (formal gegenständlich). À semelhança de Descartes, Husserl não havia entendido que, "no caráter de Ser próprio do 'eu sou', o 'sou' é decisivo e não o 'eu'"’311.

Mas por qual razão Husserl estava impossibilitado de compreender este sutil deslocamento entre os pólos "eu" e "sou"? Ora, isso se devia ao fato de que sua decisão de origem já subtraía de suas investigações o único ente ao qual poderia ser dirigida a pergunta pelo Ser. Ao ceder à tentação de excluir todos os pressupostos, ele não apenas

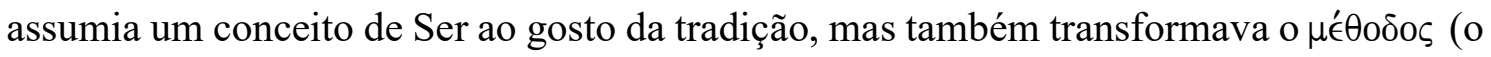

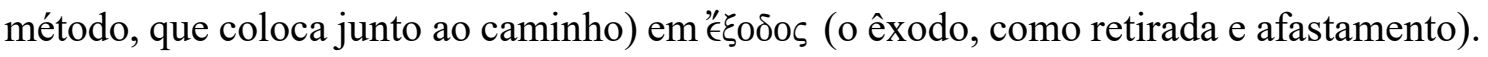
Uma vez que tudo estava colocado entre parênteses, a fenomenologia se distanciava da questão fundamental porque também submetia à eversio aquele ente notável conhecido como Dasein, quer dizer, ela seguia na direção oposta de uma verdadeira ontologia na medida em que permitia ao Dasein uma "movimentação de fuga de si mesmo"312. Fuga esta que Heidegger não cansará de censurar, advertindo tratar-se da maior das falácias fenomenológicas já narradas. Afinal, quando Husserl nos assegurava que nada se perdia

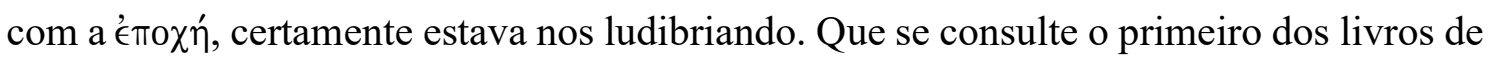
Ideias - ali se verá como o Dasein (este outro nome para o homem concreto) vai de fato se perder. Pois, com a redução, o que acontecerá conosco? Se nos declaramos bons fenomenólogos, não devemos conservar a ortodoxia e também nos "colocarmos fora do circuito de considerações"? Isto obviamente ocorrerá, afirma Husserl, visto que não há qualquer motivo para deslocarmos o sentido do Ausschalten em nosso próprio benefício. Todavia, permaneçamos tranquilos quanto ao efeito deste procedimento: como fenomenólogos “não deixaremos de existir", nem cessaremos de produzir enunciados, tal

\footnotetext{
${ }^{311}$ Idem, Phänomenologische Interpretationen zu Aristoteles, GA 61, Anhang I, p. 173-174. Courtine bem observou que Descartes e Husserl jamais poderiam colocar a autêntica pergunta pelo Ser porque seu modo de acesso ao ente se furtava ao sum enunciado na proposição fundamental. Também destacou que a distinção entre os modos de acesso explicaria a razão pela qual o mesmo ente, tomado em sua primazia, se manifestaria de modo tão díspare para Heidegger e os filósofos da eversio - quer dizer, explicaria porque a analítica existencial apresenta o Ser do "sujeito" sem recorrer a uma orientação unilateralmente subjetivista. Cf. Jean-François Courtine, Les méditations cartésiennes de Martin Heidegger, p. 103-115.

${ }^{312} \mathrm{Idem}$, Einführung in die phänomenologische Forschung, GA 17, §50b, p. 287.
} 
como fazíamos naturalmente; o que há é apenas uma modificação da visada, uma guinada na orientação, não uma eliminação. Mas se é verdade que nossa existência como homens está assegurada, esta constatação consoladora não nos autoriza a proferir, em regime de redução, qualquer juízo "referente ao nosso Dasein empírico" ou expressar "posições implícitas ou explícitas” de ordem natural. Neste sentido, a relação de um fenomenólogo consigo mesmo (com seu "individuelles Dasein") parece não se diferenciar daquela que estabelecem outros pensadores "eidéticos"; ele se comporta, por exemplo, como o geômetra: "em seus tratados científicos, os geômetras não raro falam de si e de suas pesquisas; porém, o sujeito matemático (das mathematisierende Subjekt) não pertence ao conteúdo eidético das proposições matemáticas mesmas" ${ }^{\text {"13 }}$. Eis então a sina de todo aquele que consuma a redução: para que se obtenha a tão almeja pureza, seu Dasein também deverá se encontrar enclausurado entre os parênteses e nada poderá ser pronunciado a seu respeito. Juntamente aos demais entes transcendentes, o homem experimentará esta forma muito particular de "ostracismo" - impedindo, portanto, o fenomenólogo de se inserir neste domínio que ele mesmo revelava. E se aqui ainda nos é permitido falar de um "eu”, arrependidamente resgatado em Ideias após seu exílio nas Investigações Lógicas, não é para indicar com este conceito a concreta presença do Dasein, mas para remeter, antes de tudo, àquele Blickstrahl que atravessa idealmente toda a consciência: “o eu puro é algo necessário por princípio, e como absolutamente idêntico à toda mudança real e possível das vivências, não pode vigorar em sentido algum como momento ou parte real das vivências mesmas"314. Este "ego luminoso, mas anônimo", afirma Gérard Lebrun com muito acerto, "já é a morte do homem"315. Desde então, ao fazer a opção pela eversio (e com isto gerar o colapso de todos os "pressupostos"), Husserl ignorava que jamais poderia colocar a questão pelo Ser porque, durante este processo ruinoso, soterrava (verschüttern) o único ente capaz de lhe fornecer a resposta. Perdido sob os escombros, o Dasein conhecia a deturpação (Verdrehung) de seu sentido autêntico; fugia-se de sua "incerta facticidade" em nome de uma "certa objetividade" do ente batizado como "consciência absoluta".316

Quer dizer então que, mais uma vez, tudo se passava como se o preceito de exclusão de pressupostos fosse o principal culpado por imprimir na fenomenologia as

\footnotetext{
${ }^{313}$ Edmund Husserl, Ideen I, §64, p. 137.

${ }^{314}$ Idem, Ibidem, §57, p. 127.

${ }^{315}$ Gérard Lebrun, David Hume no álbum de familia de Husserl, in: A filosofia e sua história, p. 271.

${ }^{316}$ Martin Heidegger, Phänomenologische Interpretationen zu Aristoteles, GA 61, p. 90; Einführung in die phänomenologische Forschung, GA 17, §50b, p. 287.
} 
dificuldades da qual ela padecia? Decerto - e era justamente o que Heidegger ensinava em seus Prolegômenos para a história do conceito de tempo. Constatando ali como o Ser absoluto da consciência era insuficiente em sua determinação ontológica, ele não hesitava em afirmar que este problema ocorria porque, "no sentido da redução, abria-se mão do único solo no qual podia-se perguntar pelo Ser do intencional”. Como a redução não apontava para nada mais do que a circunscrição de uma região científica, ela tergiversava de maneira incauta ao Dasein e, com ele, à pergunta fundamental: "nas reduções, tanto na transcendental quanto na eidética, a pergunta não somente não é colocada, mas é, por meio delas, certamente perdida" ${ }^{\text {317 }}$. Perda irreparável, que antes de fazer da redução o caminho para "a coisa mesma", conferia-lhe o estatuto de um extravio, de fuga de sua única via de acesso. Tal como é, ela não nos presta nenhum auxílio na investigação pelo Ser. E se algum bom husserliano ${ }^{318}$ se levantasse em defesa da fenomenologia transcendental, argumentando que tal crítica somente teria lugar na obra daquele que não compreendeu as reduções posteriores, ele certamente obteria como resposta: "se é justamente a redução que nos coloca em sérias dificuldades em relação à pergunta pelo Ser, de que valeriam outras reduções? Que sejam feitas tantas reduções quanto desejarem! Não há como resolver a questão reiterando seu entrave; seria como intentar sanar o envenenado ministrando-lhe mais do mesmo veneno". Todavia, até que ponto esta condenação integral da redução fenomenológica seria legítima? Esta recusa terminante não destoaria de certas passagens de outras preleções marburguesas sobre a mesma tópica? Ora, a ideia de que possa haver uma redução heideggeriana ao gosto de Husserl é sem dúvida sedutora, principalmente se "nós designamos como redução fenomenológica a parte fundamental do método fenomenológico em sentido da recondução da visada investigativa do ente ingenuamente apreendido para o Ser" ${ }^{319}$. Não por acaso já se escreveu que "a epoché de Husserl, sem sua conotação cartesiana, é uma ferramenta metodológica para Heidegger" ${ }^{320}$ (admiremos de passagem este breve exercício de

\footnotetext{
${ }^{317}$ Idem, Prolegomena zur Geschichte des Zeitbegriffs, GA 20, §12, p. 150-151.

318 Refiro-me aqui a Panos Theodorou, Husserl and Heidegger on Reduction, Primordiality and the Categorial (Phenomenology beyond its original divide), cap. 3, p. 67-103.

${ }^{319}$ Idem, Die Grundprobleme der Phänomenologie, GA 24, §5, p. 29.

320 " (...) the crucial method for Heidegger is that of the epoché (in both its positive and negative aspect). Only in and through the epoché - with its negative bracketing' of everyday and philosophical "gossip", and its positive unveiling of the entity in the "how" of its manifestation - can something like 'being' surface". Søren Overgaard, Husserl and Heidegger on being in the world, p. 81. Que o leitor nos permita aqui abusar de sua paciência com uma nota um pouco mais longa. Embora modorrenta, ela é necessária para esclarecer que a tese proposta por Overgaard encontra respaldo no argumento que Jean-Luc Marion apresenta em sua obra Redução e Doação (Beings and the Phenomenon, in: Reduction and Givenness, p.62-66). A fim de

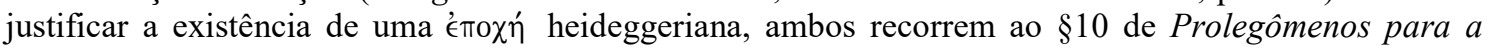


deslocamento, no qual um historiador da filosofia estranhamente ignora algo que lhe aparece como suprérfluo, a história da filosofia...). Resquícios de uma indicação merleaupontyana da Fenomenologia da Percepção? Seja lá como for, uma interpretação como esta somente adquire sentido se desconsideramos as linhas com as quais Heidegger traça seu quadro. E com isto não se quer de forma alguma dizer que o termo "redução" jamais tenha surgido na urdidura de sua filosofia - o que certamente seria absurdo, visto que os textos provam o contrário. A palavra lá está, não há dúvida; mas, toda vez que vem proferida, soa num tom desagradável aos ouvidos de Husserl. Tanto é assim que o posfácio ao primeiro dos livros de Ideias não teme em acusar a "filosofia da "existência"” de não ser nada mais que uma "nova antropologia", exatamente por desconhecer o sentido da redução ${ }^{321}$. Mas se esta "redução" se aparta da ortodoxia, a ponto de ser recusada por seu "presbítero", qual será então sua determinação? Ora, do conceito original, ela só conserva o Wortlaut, nunca sua Sache, pois aquilo que é para Husserl - afirma Heidegger em Os problemas fundamentais da fenomenologia - está distante do que é para nós. Quando nossa pretensão consiste em encontrar o Ser, devemos nos voltar "primeira e necessariamente" ao ente, uma vez que o Ser é sempre Ser do ente; somos assim levados ao ente para, em seguida, afastarmo-nos dele - não em qualquer direção, como se estivéssemos perdidos, mas sempre rumo ao seu Ser. Eis aí, portanto, a redução tal como Heidegger a compreende: sem jamais ser remetida a uma "exclusão de pressupostos" ou

história do conceito de tempo, onde se lê que "a exclusão (Ausschaltung) fenomenológica da tese transcendente tem unicamente a função de tornar presente o ente em relação ao seu Ser". De fato, Heidegger nos adverte a não compreender a "Ausschaltung der Daseinsthesis" como uma impossibilidade de lidar com o ente, uma vez que "a consideração fenomenológica trata, de modo extremo e único, da determinação do ente mesmo em relação ao seu Ser" (GA 20, §10b, p. 136). Diante disso, como não distinguir nessa passagem um elogio à redução? Não haveria um contra-senso entre a aceitação de $\S 10$ e a crítica de $\S 12$ ? Dissolver este embrolho exigirá o entendimento de algumas questões. Em primeiro lugar, ao observar que a redução não nos priva do trato com o ente, mas permite que o consideremos em vista de seu Ser, Heidegger pretende mostrar como ela, para Husserl, tem "uma tarefa ou um sentido positivo" em comparação à "exclusão de pressupostos" de Descartes: como já enunciado em Introdução à pesquisa fenomenológica, a redução não conserva o impulso à Endsituation da eversio cartesiana ("que coloca a busca diante do nada e no nada das possibilidades do encontro"), mas quer tornar visível "a totalidade do Ser numa determinada modificação temática", isto é, "situar o ente numa elaboração temática, torná-lo elaborável numa ciência buscada” (GA 17, §46a, p. 259-260). Em segundo lugar, o termo Dasein (em Daseinsthesis) se refere a todo ente transcendente à esfera da consciência e não exclusivamente ao homem. Por fim, é necessário compreender que $\S 10$ apenas oferece uma descrição da operação husserliana - que serve de base às críticas subsequentes de $\S \S 11-13$. Sendo assim, não se pode justificar, a partir daí, uma €́то $\chi \dot{\eta}$ heideggeriana sem incorrer numa interpretação vacilante, que seleciona seus excertos arbitrariamente e não observa o movimento argumentativo da obra. Cf. Marco Antonio Valentim, Heidegger sobre a fenomenologia husserliana: a filosofia transcendental como ontologia, p. 221: "No §10 da obra, 'Elaboração do campo temático: a determinação fundamental da intencionalidade', destinado a expor as teses principais da fenomenologia - teses que, nos parágrafos posteriores, serão explicitamente submetidas a reexame e crítica - já reconhecemos, na maneira como Heidegger caracteriza o procedimento da redução fenomenológica, uma tomada de posição radical frente a Husserl".

${ }^{321}$ Edmund Husserl, Nachwort zu den "Ideen I", in: Ideen III, p. 138-141. 
mencionar os famigerados "parênteses", ela nada mais é do que a "re-condução" (reducere) da visada do ente para o Ser (die Rückführung des Blickes vom Seienden zum Sein) com a intenção de finalmente cumprir a promessa de retorno à coisa mesma. "Para nós, a redução fenomenológica significa a recondução da visada fenomenológica da apreensão do ente como sempre determinada para o Ser (projetar sobre a maneira de seu desvelamento) deste ente",322.

Mas se esta "redução" - poderia questionar algum fenomenólogo fiel à sua origem husserliana - nada tem a ver com sua homônima, como justificar esta baforada de "negatividade" que ela saboreia e que, em alguma medida (e boa dose de imaginação, por

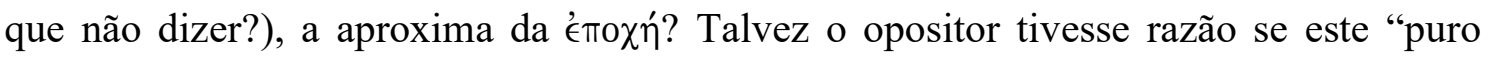
afastamento" (pure Abwendung) do ente para o Ser não fosse considerado por Heidegger cum grano salis, quer dizer, se ele não nos rememorasse que este momento "negativo" do método, além de não ser "a parte fundamental central", também carecia de um complemento "positivo". Afinal, de que adiantaria afastar a visada do ente e deter-se aí? Que valor haveria para a verdadeira ontologia num método que estivesse restrito ao "distanciamento" do ente, sendo incapaz de "aproximar-se" do Ser? Por si só, a "redução" é insuficiente: a recomendação de que devemos nos apartar do ente ainda não nos oferece um acesso ao Ser; trilhar este caminho, que conduz de um ao outro, exige uma construção. E “construir" significa necessariamente reconhecer que o ente, não obstante a necessidade de "re-condução" da visada, não pode ser encarcerado entre parênteses porque tem um papel fundamental a cumprir. Se a ontologia carece de um início e se o transcendental precisa de um lugar (Ort des Transzendentalen), não há onde mais encontrá-lo senão no ente para o qual se remete a pergunta pelo Ser: "a consideração do Ser tem no ente seu ponto de partida" ${ }^{323}$. Estamos, assim, muito distantes de uma redução em seu semblante originário. Uma reduktive Konstruktion não propõe que o ente seja colocado "fora do

\footnotetext{
${ }^{322}$ Martin Heidegger, Die Grundprobleme der Phänomenologie, GA 24, §5, p. 29. Não há boa razão para crer - como já pretendeu Jean-Luc Marion - que "Husserl comete o erro [no posfácio à Ideias I e em sua epístola endereçada a Ingarden] de atribuir um erro a Heidegger" por não compreender que, ao invés de observar "os dois lados de uma redução", seu discípulo opera "três lados de duas reduções". Cf. Jean-Luc Marion, Beings and the Phenomenon, in: Reduction and Givenness, p. 66. De maneira mais sucinta, Benedito Nunes também remeterá a uma segunda redução - ou epoché heideggeriana - que "suspende a certeza do cogito" e coloca "o Eu entre parênteses". Cf. Benedito Nunes, Passagem para o poético: filosofia e poesia em Heidegger, p. 68-69.

${ }^{323}$ Idem, Ibidem, $§ 5$, p. 30. "Não é dito que isto que constitui o lugar do transcendental não é em geral nada de ente - mas disto nasce precisamente o problema: qual é o modo de Ser do ente no qual o 'mundo' se constitui?". Idem, Brief an Edmund Husserl von 22. Oktober 1927, in: Zur Sache des Denkens, GA 14, p. 131.
} 
jogo filosófico" em favor de uma apreensão reflexiva, pois, ao contrário, ela assume que lá, "onde falta a reflexão, mostra-se o fenômeno em seu sentido mais próprio"; ao invés de se furtar à orientação natural, sua "consideração fenomenológica deve partir dela, do ente como nela se dá", "da determinação de Ser do ente concreto - a saber, do homem"324.

Mas ao tomarmos o Dasein como o ponto de partida, o que nos será permitido entrever? Ao nos voltarmos para ele, diz Heidegger, compreenderemos que sua determinação é dada em sua própria historicidade (Geschichtlichkeit). E o que vem a ser, por sua vez, esta historicidade? Ora, ela nada mais é do que "a concepção de Ser do 'acontecer' do Dasein”, é “o como e 'o que’ele já era” em seu acontecer fático - ou em termos menos empolados, ela é o passado deste ente enquanto nascer e crescer no seio de uma compreensão e de uma interpretação do Ser que há muito lhe fora transmitida. Isto quer dizer que, em sua facticidade, o Dasein não vem a ser num hiato interpretativo, como se "acontecesse" num vazio do mundo, mas encontra-se imerso numa tradição que condiciona seu próprio perguntar, "abrindo as possibilidades de seu Ser e regendo-as" 325 . Tradição pouco benevolente, é verdade, já que, em favor de si mesma, rapina ao ente a autenticidade de sua própria condução, de sua escolha e de seu questionamento; ela toma ares de dominância, e em sua dominação sempre lega algo que nos permanece encoberto. Vem daí a imposição do tradicional com a força de uma evidência óbvia que impede o acesso às "fontes originárias", a partir das quais ele mesmo foi criado. "A tradição faz com que se esqueça em geral até mesmo tal origem" 326 : o peso com o qual ela recai sobre nós inspira a ausência de sua própria compreensão e faz com que nos esqueçamos daquilo que é fundamental. Mas qual é o berço dessa tradição que aprendemos a aceitar tacitamente e que nos determina desde o início? A resposta, afirma Heidegger, é já bastante conhecida: ela repousa na "ontologia grega (na história que, mesmo através de múltiplas filiações e distorções, ainda hoje determina a conceituação da filosofia)" e na maneira pela qual "o Dasein compreende a si mesmo e o Ser em geral a partir do "mundo""327. É da filosofia antiga, portanto, que emana a tese "ontológica" que norteia todo o pensamento filosófico - e nós, convencidos de sua profundidade e obedientes à sua autoridade, sequer nos questionamos que a investigação do Ser é, a bem dizer, seu

\footnotetext{
324 Idem, Einführung in die phänomenologische Forschung, GA 17, §50b, p. 287; Prolegomena zur Geschichte des Zeitbegriffs, GA 20, §11d, p. 148.

${ }^{325}$ Idem, Sein und Zeit, §6, p. 20.

${ }^{326}$ Idem, Ibidem, p. 21-22.

${ }^{327}$ Idem, Ibidem.
} 
próprio esquecimento. "Tradição" só pode então significar metafísica, isto é, se com este vocábulo entendemos uma história da filosofia que "em parte alguma respondeu a pergunta pela verdade do Ser porque nunca se colocou esta pergunta (...diese Frage nie fragt) ${ }^{\text {"328 }}$. Convicta de perguntar pelo Ser, a metafísica nada mais fez que representar as mais diversas regiões ônticas: ela julgou o ente em sua totalidade e supôs com isso falar do Ser; ela acreditou estar em relação com o Ser quando, de fato, perscrutou o "ente enquanto ente". Assim, se a filosofia é um caminho, não deve soar estranho que sua história, tiranicamente regida pela ontologia grega, seja definida como das durchgängige Versäumnis, a falta da pergunta autêntica pelo Ser que cruza o pensamento filosófico de termo ao cabo.

Lembremos, pois, das palavras que Descartes endereçava a Picot: "assim, toda filosofia é como uma árvore, cujas raízes são a metafísica, o tronco é a física e os ramos que brotam deste tronco são todas as outras ciências...”. Essa clássica apresentação de um simplório esquema dos saberes, cuja herança se estende por todo o período da filosofia moderna, traz consigo uma boa fórmula para a descrição do papel representado pela metafísica na cena da compreensão do Ser. Diante dela, Heidegger não tardará em questionar: muito embora trate de toda a árvore e da relação entre suas partes, por que Descartes jamais mencionou o solo que a sustenta? O que é este terreno onde se espalham as raízes da metafísica e do qual elas sorvem os nutrientes necessários para o desenvolvimento de toda sua estrutura? Os filósofos, ao que parece, jamais deram a devida atenção ao fundamento, preferindo concentrar-se na árvore. Acreditaram que alcançar a raiz era prova suficiente da completude de sua tarefa, e que por isso nada mais havia a indagar; ignoravam inteiramente o solo - ou, quando muito, diluíam o parco entendimento que dele obtinham, supondo também se tratar de "algo arbóreo" (etwas Baumhaftes): "o fundamento (Grund) é fundamento para a raiz; dentro dele, ela se esquece em favor da árvore". Desnecessário então dizer que a história da filosofia não se privou de contemplar suas próprias raízes em detrimento da "terra" que lhes fornecia firmeza e substrato. Fascinada com a descoberta do "ente enquanto ente", ela renunciou à pergunta pelo Ser. "Pelo fato da metafísica perguntar pelo ente enquanto ente, ela permanece junto dele e não se volta para o Ser enquanto Ser". Assim é que $O$ que é metafísica? não cansa de nos rememorar aquilo que Ser e Tempo já anunciava: se é certo que o fundamento fora abandonado e jamais chegou a ser questão, a verdadeira metafísica

\footnotetext{
${ }^{328}$ Idem, Einleitung zu: “Was ist Metaphysik? “, in: Wegmarken, GA 9, p. 370.
} 
passa a ser algo que filósofo algum honestamente proferiu; observada desta perspectiva, ela é das Ungesagte que faz com que a "essência da metafísica seja bem outra coisa que a própria metafísica" ${ }^{329}$. Saibamos então reconhecer - diz Heidegger - que isto que se convencionou denominar "metafísica” já não poderá ser grafado sem as aspas, uma vez que o fundamental the permanece desconhecido e infundado (der unbekannte ungegründete Grund). E se, doravante, algum bom espírito decidir-se por colocar a “pergunta pelo Ser”, precisará ter em mente que não poderá fazê-lo conforme os desígnios ônticos tradicionais, mas deverá pensar a metafísica "não mais metafisicamente" ${ }^{330}$.

Guardemo-nos, no entanto, de tirar daí conclusões preciptadas. Quando Heidegger nos convida a "não mais pensar metafisicamente", isto não significa que esteja nos incitando a pensar contra a "metafísica". Caso desejemos insistir um pouco mais na metáfora cartesiana, a postura a ser conservada em relação à "metafísica" não é a de alguém que procura extrair as raízes do solo, como se violentamente arrancasse dali uma erva daninha, mas é, antes de tudo, a ação de quem sulca a terra, arando-a e cultivando-a em favor das raízes que nela se deitam. Logo, nada nos autoriza a falar de uma "abolição" da "metafísica" - pois este termo pertence ao glossário dos pensadores de orientação cética, a quem agrada iniciar suas considerações com uma eversio. Em vez de "abolir", tratemos de "superar": longe de representar um degredo, a superação da "metafísica" quer somente fazer justiça ao seu nome, cumprindo a velha promessa de transição - que leva para além $(\mu \in \tau \alpha)$ do ente $(\phi \cup \sigma\llcorner\kappa \alpha)$ em direção ao Ser. "A metafísica permanece o primeiro da filosofia (das Erste der Philosophie). Contudo, ela não alcança o primeiro do pensamento (das Erste des Denkens). A metafísica está superada no pensamento da verdade do Ser" ${ }^{\prime 31}$. Assim, o que há é uma retomada do caminho e a intenção de recolocar a metafísica naquele curso do qual a $ф\llcorner\lambda \circ \sigma o \phi i ́ \alpha$ se desviara ao digladiar, em sua aurora, contra as "verdades" venais da sofística ${ }^{332}$. Quer dizer então que devemos retroceder a

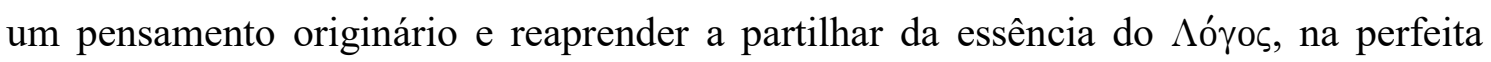

\footnotetext{
329 “O pensamento tentado em Ser e Tempo está 'a caminho' para situar o pensamento num caminho em cuja marcha possa alcançar o interior da relação da verdade do Ser com a essência do homem; está em marcha para abrir ao pensamento uma senda na qual medite propriamente o Ser mesmo em sua verdade. Idem, Ibidem, GA 9, p. 366-372.

330 "Este perguntar deve metafisicamente pensar e pensar simultaneamente a partir do fundamento da metafísica, isto é, não mais metafisicamente”. Idem, Nachwort zu: "Was ist Metaphysik? “, in: Wegmarken, GA 9, p. 304.

${ }^{331}$ Idem, Einleitung zu: "Was ist Metaphysik? “, in: Wegmarken, GA 9, p. 367.

332 "Desta maneira, a palavra grega $\phi \iota \lambda \circ \sigma o \phi i ́ \alpha$ [filosofia] é um caminho sobre o qual estamos a caminho (...) A filosofia está a caminho do Ser do ente, isto é, do ente em relação ao seu Ser”. Idem, Was ist das die Philosophie?, in: Identität und Differenz, GA 11, p. 6 e 15.
} 


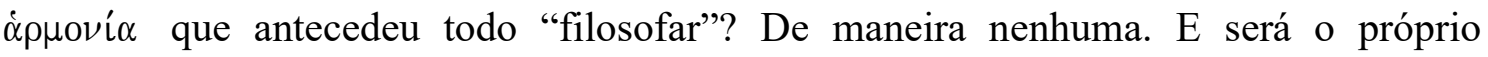
Heidegger a nos dissuadir da opinião de que basta proclamar a renascença do pensamento de Heráclito e Parmênides para responder a pergunta pelo Ser. Seríamos meramente "vaidosos e proferiríamos um contra-senso" ao observarmos a questão de tal perspectiva. Mesmo que tenham sido eles os "maiores pensadores", sempre atentos à voz do Ser, nada nos permitiria repetí-los. Sem simplesmente transcrevê-los, conservemos destes présocráticos a valiosa lição de dirigirmos toda nossa atenção à "chegada impronunciada do desvelamento" que o Ser anuncia, isto é, àquilo que a história da metafísica insistiu em $\operatorname{velar}^{333}$.

Contudo, como proceder na retirada deste véu que até aqui encobriu o Ser? Como desfazer esta confusão entre Ser e ente que assolou indistintamente toda a filosofia? Ora, se a herança grega se estruturou sobre o que é originário, impedindo-lhe o acesso $e$ obstruindo-lhe (verbauen) a apreensão, nada mais há de se fazer senão destruí-la (abbauen). Nesse sentido, qualquer pretensão de construção da verdadeira ontologia passa, obrigatoriamente, pela destruição:

"Esta tarefa nós entendemos como a destruição (Destruktion) da existência tradicional da ontologia antiga (consumando-se no fio condutor da pergunta pelo Ser) até as experiências originárias nas quais foram obtidas as determinaçãoes do Ser que são primeiras e, desde então, condutoras ${ }^{, 334}$.

Necessidade de fazer ruir todo o antigo edifício, para que comecemos a empilhar, no lugar de seus escombros, outros tijolos conforme as regras de uma nova arquitetura... Quão

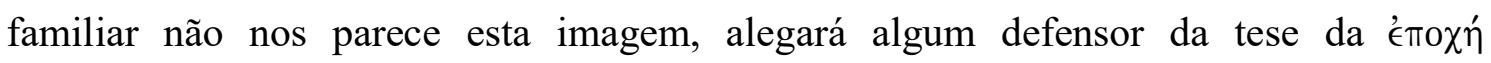
heideggeriana. De fato, uma primeira leitura poderia oferecer a viva impressão de termos diante dos olhos uma tradução germânica do final da primeira meditação ou um testemunho favorável à metodologia de Ideias - os quais nos levariam a acreditar que, apesar das muitas acrobacias conceituais, Heidegger ainda permanecia um inconfesso partícipe do círculo de filosófos que empregavam o preceito da eversio. Mas esta "primeira leitura" nada mais é que uma interpretação ligeira e enviesada, iludida pela

\footnotetext{
333 “Heráclito e Parmênides ainda não eram 'filósofos'. Por que não? Porque eram os maiores pensadores. 'Maiores' não designa aqui o cálculo de um rendimento, porém aponta para outra dimensão do pensamento". Idem, Was ist das - die Philosophie?, in: Identität und Differenz, GA 11, p. 15; Einleitung zu: "Was ist Metaphysik? ", in: Wegmarken, GA 9, p. 369-370.

${ }^{334}$ Idem, Sein und Zeit, §6, p. 22.
} 
possibilidade desse falso flerte. Não nos enganemos: a "destruição" jamais se deixou guiar pelo desaprumo de Descartes e de seus acólitos, sendo seduzida pela proposta de exclusão de todos os pressupostos. Em momento algum ela cedeu à soberba da Unbedürftigkeit e inclinou-se à instituição do saber absoluto por temer o erro. Pois quem disse que a história da filosofia é um erro? "Nosso ponto de partida - escreverá Bento Prado Júnior, em palavras definitivas - nada tem de cartesiano, da démarche du chevalier du Poitou, qui partit d'un si bon pas, considerando a tradição da filosofia uma verdadeira historia stultitiae; partimos do fundo da história da metafísica onde os 'esquecimentos' (não os erros) são fundamentais para a retomada do movimento do pensamento" ${ }^{335}$. É por isso que a "destruição" não faz eco à terceira das Regulae. Se Heidegger insistiu na necessidade de "destruir" a antiga tradição, em parte alguma relatou que sua consumação ocorria por meio de uma hostilidade em relação à história (Geschichtsfeindlichkeit). Deixemos aos diletantes, portanto, esta "incapacidade fundamental" de compreender o que é histórico, bem como a crença em uma "evidência ingênua" que possa nascer de uma ausência da história (Geschichtslosigkeit). De nossa parte, recomenda Heidegger, saibamos reconhecer que a história da filosofia enquanto "confusão [entre Ser e ente] é para ser pensada como um acontecimento, não como uma privação" ${ }^{\text {336: }}$ um acontecimento que não gera nenhuma aversão (por ser supostamente errôneo) e não exige "o sentido negativo do abalo da tradição ontológica".

Assim, não julguemos a "destruição" como "negação e condenação", ou mesmo como uma espécie de coveiro que sela o féretro e "sepulta o passado na nulidade", mas tratemos de entendê-la como uma "apropriação positiva, cujas funções negativas

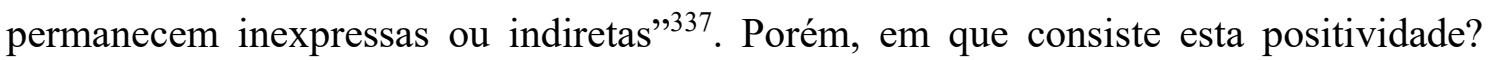
Muito longe de comungar com a negatividade do asco às praejudicatae opiniones dos filósofos que nos precederam, este processo destrutivo revela sua essência positiva ao voltar para a história uma visada crítica. O que nada tem a ver, a bem dizer, com o trabalho convencional de um historiador que toma o pensamento filosófico como objeto e procura expor seu movimento. Sem pender à mera historiografia, a crítica histórica ao

\footnotetext{
${ }^{335}$ Bento Prado Júnior, Ipseitas, p. 102-103.

${ }^{336}$ Martin Heidegger, Einleitung zu: "Was ist Metaphysik?", in: Wegmarken, GA 9, p. 370; Ontologie (Hermeneutik der Faktizität), GA 63, §15, p. 75; Einführung in die phänomenologische Forschung, GA 17, §36, p. 213-214. Cf. Claudia Serban, La phénoménologie de la conscience comme fuit devant le Dasein: l'interprétation heideggériene de Husserl à Marburg em 1923-1924, in: Heideggers Marburger Zeit: Themen, Argumenten, Konstellationen, p. 237-254.

${ }^{337}$ Idem, Sein und Zeit, §6, p. 22.
} 
gosto de Heidegger recai sobre o presente; seu alvo é o Dasein hodierno, na medida em que ele se encontra encoberto "por um passado que se fez impróprio". Noutras palavras, criticar significa reconhecer que este passado, embora não seja todo fausto (já que se furta à pergunta pelo Ser), não chega a ser todo funesto (a ponto de forçar a repugnância que Descartes e Husserl conservavam para com ele). Pois, quando nos propomos a observálo positivamente, nossa motivação já não repousa em elencar suas fraquezas com a finalidade de eliminá-lo; o que se pretende, na verdade, é "tornar visível o positivo propriamente originário no passado"338. Afinal, a história da filosofia não é muda, mas tartamuda - o que faz toda a diferença: embora sua preocupação estivesse direcionada ao ente, em certas ocasiões ela não deixou de tangenciar aspectos relativos ao Ser. Ainda que numa fala arrastada e empatada, ela tem algo a nos dizer. Daí Heidegger afirmar que "a resposta à pergunta pelo Ser não jaz numa proposição isolada e cega" (o cogito, ergo sum, talvez?): "não tem nenhuma importância e permanece uma exterioridade se a resposta é 'nova'; o positivo reside no fato dela ser suficientemente antiga, para que aprenda a compreender as possibilidades proporcionadas pelos 'antigos" "339. Por isso, se é verdade que a destruição consiste numa "luta com o passado" (Kampf mit der Vergangenheit) que esqueceu-se do fundamental, ela somente o é enquanto uma operação que retira o passado de sua impropriedade e o traz para seu Ser próprio, quer dizer, enquanto um movimento que impulsiona em direção ao presente o que há de original no passado e ata o "hoje" à "história" (Geschichte). Em suma, "destruir" não é incitar o desprezo, mas é fazer nascer uma "veneração pela história (Ehrfurcht vor die Geschichte), na qual nós vivemos nosso próprio destino (Schicksal)"; "destruir" é, portanto, compreender que a eversio, em qualquer uma de suas figuras, carece de sentido porque ignora o geschichtlich como geschick-lich ${ }^{340}$.

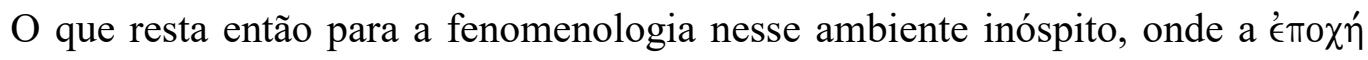
perde o protagonismo de seu sentido e onde o "novo" domínio da consciência absoluta -

\footnotetext{
${ }^{338}$ Idem, Einführung in die phänomenologische Forschung, GA 17, § 20, p. 118-119.

${ }^{339}$ Idem, Sein und Zeit, §5, p. 19. Franco Volpi, em seu belo livro Heidegger e Aristotele (sobretudo no terceiro capítulo), fornece um ótimo exemplo do uso que Heidegger faz da destruição em sua relação com a filosofia aristotélica. Cf. Franco Volpi, Heidegger e Aristotele, p. 39-109.

${ }^{340}$ Idem, Einführung in die phänomenologische Forschung, GA 17, § 20, p. 119-122; , Was ist das - die

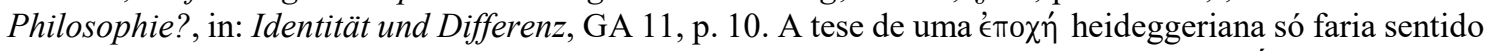
se retirássemos, erroneamente, todo o peso metodológico do conceito de "destruição". É o que faz, por exemplo, Overgaard: "in other words, the problem of 'destruction' is not of crucial importance in a discussion of an explicit posing of the question of being (...)". Søren Overgaard, Husserl and Heidegger on being in the world, p. 99-100.
} 
apesar da insistência de Husserl em afirmar o contrário - não passa de um ancoradouro à antiga noção de substância? Deve-se concordar com o crítico que, de maneira desdenhosa, a julga uma peça do passado, como apenas mais uma das doutrinas que compõem a história da filosofia, sem nada a nos oferecer? Não, sobretudo não - dirá Heidegger. Pois justamente por podermos pensá-la como "passado", inscrita no seio de uma tradição silente, é que a fenomenologia também experimenta os efeitos da destruição e faz-se "crítica contra si mesma, em um sentido positivo"341. Não nos esqueçamos de que há certa loquacidade na "mudez" e que toda fala daí proveniente ainda tem algo a ensinar. E neste caso particular, muito embora o pensamento fenomenológico originalmente não tenha cumprido sua tarefa, ele se torna para nós crucial se o "trouxermos de volta para si mesmo, em sua possibilidade mais própria e mais pura". Se há nele alguma grandeza, ela não se encontra na avaliação de seus resultados ou no prolongamento de seu estado atual, mas em sua descoberta enquanto possibilidade de investigação filosófica. "As elucidações do conceito prévio de fenomenologia indicam que, para ela, o essencial não está em ser como “diretriz" filosófica real. Mais elevada do que a realidade está a possibilidade. A compreensão da fenomenologia jaz unicamente em apreendê-la como possibilidade" 342 . Todavia, o que significa esta passagem da realidade para a possibilidade? Nada mais, nada menos que o reconhecimento de que a fenomenologia deixa de desfrutar da condição à qual Husserl a alçara, e que o fenomenólogo vai agora abandonar a velha presunção de concebê-la numa identidade entre a questão filosófica e seu método. Em regime de destruição, ela perde a velha pompa de "ciência rigorosa", que avança autonomamente e preocupa-se somente consigo, e retoma o lugar que lhe cabe - ao rememorar a lição que Heidegger esboça em versos:

“Contudo - método e caminho são

o mesmo? Na época tecnológica deve-se

meditar a particularidade do

caminho na diferença com o método?

De fato - é preciso provar esse estado-de-coisas.

Ele se deixa, do modo mais nítido, nomear

\footnotetext{
${ }^{341}$ Idem, Sein und Zeit, §7c, p. 36.

${ }^{342}$ Idem, Mein Weg in die Phänomenologie, in: Zur Sache des Denkens, GA 14, p. 102; Sein und Zeit, §7c, p. 38 .
} 
na língua grega, ainda que a seguinte sentença

encontre-se nenhures no pensamento dos gregos.

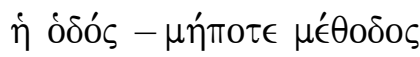

O caminho jamais (é) um proceder." 343

Uma vez "destruída", jogando "criticamente contra si mesma", a disciplina que outora gozava de "absoluta independência" ${ }^{344}$ nas considerações transcendentais de Ideias já não deve ser concebida como uma investigação fixa e definitiva, bastando-se e esgotando-se em seus próprios limites. Não a tratemos, portanto, como $\dot{\eta}$ ódós: ela não é o caminho fundamental que precisamos percorrer. Mas saibamos observar, apesar disso, que ela

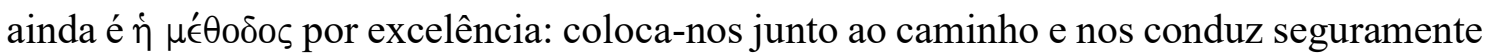

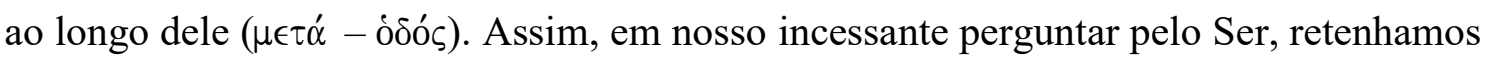
a fenomenologia como o conceito de método que, ao "conservar aberta a tendência às coisas mesmas", pode nos "livrar das condições inautênticas da tradição" - permitindo não apenas contemplar o ente enquanto ente, mas o "ente enquanto ente em seu Ser". “Colocar fenomenologicamente essa pergunta significa, seguindo seu sentido, colocá-la de modo que ela se torne uma pergunta que pesquisa e questiona a partir das coisas mesmas"345.

Eis aí o semblante do que será a fenomenologia nas páginas de Ser e Tempo: um método - e nada além disso. Mas um método devidamente depurado, que não estará diluído no caminho pelo qual deve nos guiar. Por isso, não esperemos ouvir dele qualquer palavra acerca do Was dos objetos. Este equívoco, deixêmo-lo a Husserl. Quando bem compreendido (o que equivale a dizer, quando compreendido segundo o étimo grego), o método diz respeito somente ao Wie: ele se pronuncia sobre como o objeto vem a ser, não sobre o que é. O que nos leva, então, à questão: de que maneira a fenomenologia nos coloca no caminho e $a$ caminho da resposta para a pergunta pelo Ser? Como determinar este Wie, sem o qual a indagação pelo Ser não poderá se consumar? Encontrar a resposta, confessa Heidegger, não exigirá que abandonemos esse território no qual nos situamos. Não será preciso ir além da "fenomeno-logia" ela mesma: para revelar o sentido da máxima "zu den Sachen selbst!", basta que aclaremos o significado de seu nome tal como

\footnotetext{
${ }^{343}$ Idem, Der Fehl heiliger Namen, in: Aus der Erfahrung des Denkens, GA 13, p. 233.

${ }^{344}$ Edmund Husserl, Ideen I, §60, p. 129.

${ }^{345}$ Martin Heidegger, Prolegomena zur Geschichte des Zeitbegriffs, GA 20, §14, p. 184-186.
} 
fizemos com $\dot{\eta} \mu^{\prime} \in \theta_{o \delta} \varsigma$, ou seja, que entendamos de maneira fundamentalmente grega o significado de $\phi \alpha \iota \nu o ́ \mu \epsilon \nu$ o e $\lambda o ́ \gamma o \varsigma$. E, para isto, é aconselhável retornar brevemente a

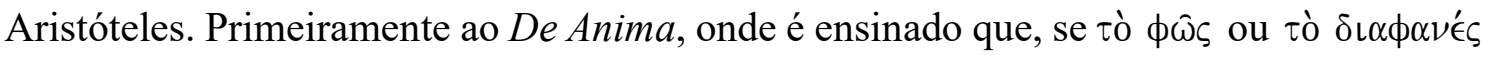
possibilitam que algo se mostre, este algo que agora se torna visível, "mostrando-se-em-

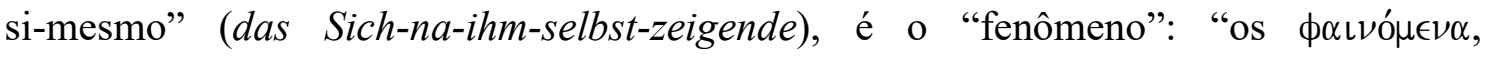
'fenômenos', são a totalidade do que está à luz ou que pode ser trazido à luz, o que os gregos identificam, as vezes, simplesmente como $\tau \grave{\alpha}$ o’ $\nu \tau \alpha$ (os entes) ${ }^{3446}$. Em seguida,

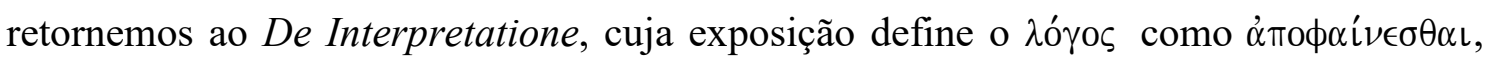
como a fala que não somente deixa ver ( $\phi \alpha \dot{L} \nu \in \sigma \theta \alpha \iota)$, mas que deixa ver “ “ $\alpha$ mó...”, a partir

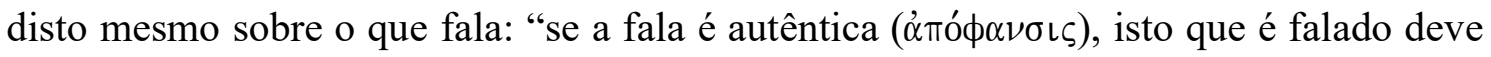
ser criado a partir disto sobre o que se fala, de modo que a comunicação falante em seu dito torne claro e, assim, acessível aos outros isto sobre o que fala" ${ }^{347}$. Vem daí então a determinação da própria fenomenologia. É graças aos termos lapidares extraídos da obra do Estagirita que poderemos compreender que "fenomeno-logia" não é senão um $\lambda^{\prime} \gamma_{\epsilon} \downarrow \nu$

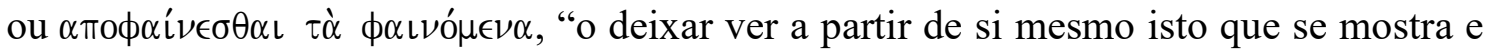
tal como se mostra a partir de si”. E ao ser assim delineada, ela nos permitirá observar que, enquanto método, a essência do Wie repousa na "demonstração" e na "identificação" diretas do Was em questão, possibilitando sua manifestação. Desde então, só se poderá falar em "fenomenologia descritiva" se por "descrição" entendermos o "deixar ver, sem entremeios, aquilo que se mostra" e o afastamento de toda determinação que não seja dada desta maneira. Mas se a fenomenologia é um "deixar ver o que se mostra a partir de si mesmo", o que ela "deixa ver" que método algum jamais permitiu que fosse visto? "O que é isto - pergunta Heidegger - que deve ser denominado 'fenômeno' em um sentido excepcional?" Ora, a esta altura, a resposta dada à pergunta já não nos parecerá em nada supreendente. Porque, no cumprimento de sua tarefa, a fenomenologia deixará que se veja o que sempre permaneceu velado e esquecido, aquilo que mesmo não se mostrando constitui o fundamento e o sentido de tudo que até aqui se mostrou. E isto que jamais abandonou o ocultamento, permanecendo encoberto ou deslocado, é o próprio $\mathrm{Ser}$ do ente. Assim, se falamos agora num "retorno à coisa mesma", é no sentido de um retorno fenomenológico ao Ser - exprimindo-nos numa fala bem articulada, que enfim rompe o silêncio e responde verdadeiramente a questão fundamental ausente na história da

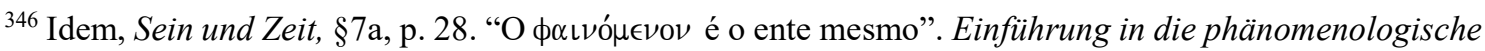
Forschung, §1b, GA 17, p. 13. Cf. Aristóteles, De Anima, 418b 13 sq.

${ }^{347}$ Idem, Sein und Zeit, §7b, p. 32. Cf. Aristóteles, De Interpretatione, $16 \mathrm{~b} 19$ sq.
} 
filosofia. É por esta razão, portanto, que Heidegger não hesitará em afirmar que "a ontologia somente é possível como fenomenologia": uma vez que “"atrás” do fenômeno da fenomenologia essencialmente não há nada”, o que se deixará ver, tal e qual se mostra, é o Ser em toda sua limpidez ${ }^{348}$.

Sob este aspecto, a fenomenologia se tornará insubstituível para uma investigação sobre o Ser. O que, por certo, não quer dizer que este "perdão" concedido pela "crítica destrutiva" nos incite ao retrocesso de uma situação que há pouco fora julgada de maneira tão severa. Esta honra que agora se confere ao método não nos convida a retornar àquela condição de indignidade silenciosa - ontologicamente silenciosa - de uma filosofia da consciência pura. É verdade que Heidegger, muito honestamente, não deixará de nos rememorar que a doutrina de Husserl é a responsável por nosso caminhar pelo caminho, sem extravios: é graças a ela que obtemos um ponto de partida (Ausgang), que podemos transitar (Durchgang) pelos encobrimentos dominantes e, enfim, acessar (Zugang) o "fenômeno". Mas também é verdade que a fenomenologia de Ser e Tempo, apesar do reconhecimento de sua dívida, não será mera efígie do pensamento alinhavado em Ideias ou mesmo das Investigações Lógicas. Pois se Heidegger assegura que a "descrição" é necessária na demanda por uma resposta à pergunta fundamental, resta que, naquelas páginas, ela somente recebe seu pleno direito de cidadania ao se converter em interpretação. Que a fenomenologia possa então vir ao centro do proscênio, implica no fato de que esteja devidamente trajada com as vestes da hermenêutica. Enquanto fenomenologia hermenêutica ela já não se configura como a posse fixa de um saber absoluto, uma ciência rigorosa na acepção husserliana, mas manifesta-se como um despertar propriamente filosófico, no qual o Dasein, ao se encontrar, compreende-se como "o estar a caminho de si mesmo" (das Unterwegs seiner selbst zu ihm). "Estar filosoficamente desperto significa: viver numa auto-interpretação originária, na qual a filosofia deu-se por si mesma, de tal modo que ela constitui uma possibilidade decisiva e um modo de auto-encontro do Dasein" "349. Uma vez devidamente "despertos", poderemos falar sobre aquilo que o Hauptthema fenomenológico calou. Afinal, se não há dúvidas de que "com a descoberta da intencionalidade é dado expressamente e pela primeira vez em toda a história da filosofia o caminho para uma radical pesquisa ontológica", não se deve ignorar que, nesta volta do Dasein para si mesmo, a interpretação nos permitirá observar

\footnotetext{
${ }^{348}$ Idem, Ibidem, §7c, p. 35-36.

${ }^{349}$ Idem, Ontologie (Hermeneutik der Faktizität), GA 63, §3, p. 17-18.
} 
estruturas ainda mais originárias, situadas aquém da pretensa generalidade última do "relacionar-se com..." (Sichverhalten zu...) ou "estar-relacionado-a-algo" (Bezogensein-

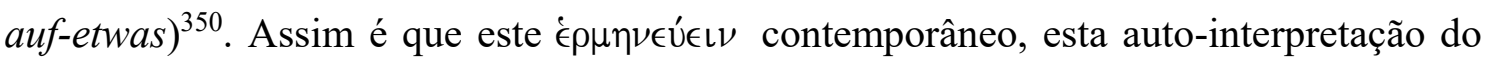
Dasein em sua facticidade, colocará em descoberto a ontologia autêntica e fundamental, responsável por determinar as demais ontologias. Trata-se, portanto, de uma verdadeira "filha de Hermes": por ser hermenêutica, abre o caminho que conduz a todos os caminhos - o que equivale a dizer, num jargão tipicamente filosófico, que ela não é senão "a elaboração das condições de possibilidade de toda investigação ontológica". "Filosofia é ontologia fenomenológica universal partindo da hermenêutica do Dasein, a qual, enquanto analítica da Existência, amarra o fim do fio condutor de todo questionamento filosófico no lugar onde ele brota e para onde retorna" ${ }^{351}$. Na glosa sempre refinada de Benedito Nunes, eis aí a via para o Ser: a interpretação do Dasein que nós mesmos somos, como o ente que compreende o Ser, como o lugar da travessia ${ }^{352}$. Eis aí "o caminho concreto" (der konkrete Weg) que nos livra dos excessos do idealismo.

\section{II - A primazia do Dasein}

Quando Husserl escrevia em seu terceiro livro de Ideias que "a maravilha de todas as maravilhas eram o eu puro e a consciência pura", não podíamos deixar de notar seu tom quase zombeteiro: ao empregar a expressão de maneira despudorada, ele o fazia com a clara intenção de desmistificar seu teor, assegurando que o destino desta "maravilha" era desvanecer no exato momento em que "a luz da fenomenologia" (com sua análise eidética) recaisse sobre ela e a modificasse "em uma ciência com uma completude de

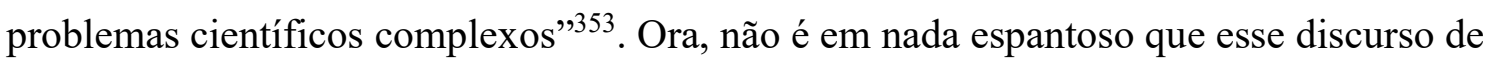
elevação da cientificidade absolutamente racional em detrimento da "maravilha" nasça

\footnotetext{
350 "Fenômenos de que não nos damos conta, caso sejam determinados como intencionalidade. Não posso apreender o fenômeno da angústia como um estar-relacionado-a-algo, pois ele é um fenômeno do Dasein mesmo". Idem, Einführung in die phänomenologische Forschung, GA 17, §46b e §50b, p. 260 e 288 . Ou ainda: "em geral, isto não é nenhum relacionar-se com...(intencionalidade), mas um como do Dasein mesmo; terminologicamente, fixa-se desde o princípio como estar desperto do Dasein para si mesmo". Idem, Ontologie (Hermeneutik der Faktizität), GA 63, §3, p. 15.

${ }^{351}$ Idem, Sein und Zeit, §7c, p. 38.

${ }^{352}$ Benedito Nunes, Passagem para o poético. Filosofia e poesia em Heidegger, p. 60-61. Benedito Nunes não oculta sua forte inspiração rosiana na remissão à "travessia": "existir e viajar se confundem (...) além de viajante, o homem é a viagem - objeto e sujeito da travessia, em cujo processo o mundo se faz". Idem, A Rosa o que é de Rosa. Literatura e filosofia em Guimarães Rosa, p. 80-85.

${ }^{353}$ Edmund Husserl, Ideen III, §12, p. 75.
} 
da reflexão de um filósofo da eversio, que não faz senão pastichar Descartes. E será ainda menos surpreendente que Heidegger venha a censurar Husserl justamente por este motivo. Era na epístola de outubro de 1927 que o discípulo, expondo o problema central de sua obra, repreendia secretamente o mestre não apenas por ignorar a lição do Teeteto, mas também por renunciar, de maneira deliberada, à própria "maravilha" ("das Wundersame") com sua operação metódica ${ }^{354}$. Em poucas palavras e numa linguagem mais sutil, ali transparecia a crítica já engendrada nos Prolegômenos para a história do conceito de tempo: ao arrastar o homem concreto para o interior de seus parênteses, a fenomenologia condenava-se, de partida, a não responder a pergunta pelo Ser; por culpa da redução, ela era míope ao papel estratrégico desempenhado pelo Dasein na investigação ontológica. Mas que papel seria este? Ou melhor: se o Dasein surge como um personagem de importância tão larga, se ele é dito o ente para o qual é necessário retornar (a fim de que se possa decifrar o Ser), por qual razão nós permitimos que ele ocupe esse posto de lisonja e não um outro ente? Por que exatamente ele vai se converter no $\theta \alpha \hat{u} \mu \alpha$ do filósofo?

Se o Dasein pode desfrutar desta condição - garante-nos Heidegger - é porque, em meio à multiplicidade do ente, ele não surge como um ente semelhante aos demais. Há um certo privilégio que o cerca e uma certa primazia que o coroa: sua distinção de todo e qualquer ente reside no fato de que, para ele, “o Ser está em jogo em seu próprio Ser". E que "o Ser esteja em jogo em seu próprio Ser" significa "que a compreensão de Ser ela mesma é uma determinação de Ser do Dasein", que em seu modo de Ser ele é na compreensão do $\mathrm{Ser}^{355}$. Assim, é por estar nesta estreita relação com o Ser (sendo ontologicamente) que o Dasein desperta-nos, num primeiro momento, para o $\theta \alpha \nu \mu \alpha ́ \zeta \epsilon \iota \nu$. Mas isto evidentemente não é tudo. Pois se é verdade que "o ente que compreende o Ser" já não se confunde com os outros entes, nada mais parece nos autorizar a proferir a afirmação de que ele simplesmente “é”. É que o Dasein, este ente que nós mesmos somos, não encontra seu fundamento a partir da pergunta “o que (was) é isto?". Caso indagássemos "o que é o Dasein?", incorreríamos num problema que já havíamos afastado; pressupondo a estrutura da questão (quid est res?), seríamos levados de volta aos marcos da tradição e equipararíamos o Dasein ao "ente simplesmente dado"

\footnotetext{
${ }^{354}$ Martin Heidegger, Brief an Edmund Husserl von 22. Oktober 1927, in: Zur Sache des Denkens, GA 14, p. 131.

${ }^{355}$ Idem, Sein und Zeit, §4, p.12.
} 
(vorhanden). Como filósofos desejosos de tecer uma ontologia autêntica, evitemos então retornar à antiga quietude e tratemos de modificar a pergunta. Para que haja uma via de acesso legítima ao Ser do ente, não mais perguntemos "o que é...?” e sim "quem (wer) é...?”: “o Dasein não é constituído pela Washeit [o que é], mas - se nós podemos empregar a expressão - pela Werheit [quem é]"356. Quem é o Dasein? - convém, pois, reformular o questionamento. E reformulando-o, a resposta jamais poderá ser a coisa pura e simples, comungando o modo de Ser de outros entes, mas "será um eu, um tu, um nós"357. Se agora nos é permitido falar numa modificação em fenomenologia-hermenêutica, é no sentido muito específico de não mais perguntar pela relação estabelecida entre o que é (Washeit) e o ente simplesmente dado (Vorhandenheit), mas sobre quem é (Werheit) e a existência (Existenz). Eis aí, portanto, a existência - este modo de Ser que somos (à diferença dos demais entes) e que tanto nos maravilha: "o ente que é no modo da existência, é o homem. Somente o homem existe. O rochedo é, mas não existe. A árvore é, mas não existe. $\mathrm{O}$ cavalo é, mas não existe. O anjo é, mas não existe. Deus é, mas não existe" ${ }^{\text {"358. }}$.

Mas ao definirmos a "essência" do Dasein como sua existência, anunciando-a como uma boa nova, não estaríamos apenas exaltando algo que não passa de uma lição medieval com um verniz de "autenticidade"? Não estaríamos propondo um retorno puro e simples ao conceito escolástico de existentia? Na verdade, estamos muito longe disso. E Heidegger não tardará em afastar qualquer suspeita que possa surgir nesse sentido. Quando empregamos o termo existentia, diz ele, sob nenhuma hipótese nos referimos ao modo de Ser próprio do homem, mas remetemos ao "ser simplesmente dado" (vorhandensein), à tradicional compreensão do ente em seu Was. Muito embora os nomes soem de modo semelhante, a proximidade de sua grafia não aparece como um instrumento de medida confiável de seu significado - ao contrário, ela não faz senão ressaltar o falso grau de parentesco entre os conceitos. Que não sejamos então tentados a crer que a Existenz somente traduza para uma linguagem contemporânea aquela determinação bruta da qual já se mostrou a impropriedade; entendamos, antes de tudo, que entre existentia e Existenz há uma incomensurável distância. E isto porque a "existência” tingida em cores heideggerianas vai abandonar de uma vez por todas o terreno da clássica noção de ontologia para ser compreendida como "o Ser mesmo ao qual o Dasein pode se relacionar

\footnotetext{
${ }^{356}$ Idem, Die Grundprobleme der Phänomenologie, GA 24, §12c, p. 169.

${ }^{357}$ Idem, Ibidem.

${ }^{358}$ Idem, Einleitung zu: ”Was ist Metaphysik? “, in: Wegmarken, GA 9, p. 374-375.
} 
deste ou daquele modo e com o qual sempre se relaciona de alguma maneira", quer dizer, aquela "concepção de Ser na qual reside a ideia de Ser em geral" ${ }^{359}$. Assim, enquanto um modo de Ser excepcional, "existir" consistirá na "essência ek-stática" (das ek-statische Wesen) do Dasein, naquela experiência singular de sempre ser lançado "para fora". Em poucas palavras, existir significa transcender; sendo, o homem transcende. Contudo, ao afirmarmos que a transcendência corresponde ao modo de Ser do Dasein, não escorregaríamos pela cascata do "absurdo"? Não o estaríamos aprisionando - mais uma vez - na esfera das "coisas", da qual tanto nos esforçávamos para libertá-lo? Ora, uma pergunta como esta só poderia ser feita por aquele que ainda não pôde entrever o verdadeiro sentido do transcender. Pois se é verdade que a teoria do conhecimento faz questão de sublinhar que o transcendente é aquilo que jaz fora do sujeito, ultrapassando as fronteiras da subjetividade, também é certo que a analítica existencial se empenhará em subverter esse juízo. Para Heidegger, a transcendência como o passo que se dá além (ultra-passar) nada tem a ver com o Ser das coisas, pois "a coisa nunca transcende e o transcendente nunca é no sentido do que ultrapassou"360; por obra e graça da hermenêutica, a verdadeira definição ontológica da transcendência caminha na direção oposta das teses gnosiológicas vigentes: a partir de agora, o transcendente só poderá ser visto como aquele que ultrapassa (“o ultrapassante”, das Überschreitende) e não mais como aquilo para o qual se ultrapassa. Tudo se passa, portanto, como se Heidegger recusasse abertamente as determinações da fenomenologia transcendental, como se mostrasse que Husserl - na segunda preleção de seu A ideia da fenomenologia - via um cisco no olho do psicólogo, mas não a farpa no próprio olho. É que já não há boa razão para insistir numa "imanência autêntica" cuja assunção serve apenas para nos insular num ente regional, incapaz de ofertar a resposta para a pergunta pelo Ser. Caso desejemos, de fato, instituir uma ontologia fundamental, devemos compreender que "o Dasein é transcendente em seu Ser e não o imanente", "que pertence à sua estrutura de Ser mais

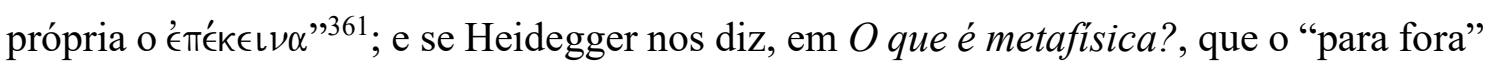
(Hinaus) não é nenhum "afastar-se da (Weg von) interioridade da imanência da consciência", é para nos lembrar - "por mais estranho que isso soe" - que somente permanecemos no interior (Innestehen) na medida em que ele in-siste em ser aí e para

\footnotetext{
${ }^{359}$ Idem, Sein und Zeit, §4, p. 12-13.

${ }^{360}$ Idem, Die Grundprobleme der Phänomenologie, GA 24, §20, p. 424.

${ }^{361}$ Idem, Ibidem, GA 24, §20, p. 425. Cf. Denis Fisette, Les cours de Marburg et la phénoménologie, p. 303-321.
} 
fora: "isto que deve ser pensado sob o nome 'existência', quando a palavra é usada no seio do pensamento que pensa na direção da verdade do Ser e a partir dela, poderia ser denominado, do modo mais belo, pela palavra 'insistência", ${ }^{962}$. Daí se vê que seria preciso que houvesse muito boa vontade para acreditar que o Dasein seja apenas um outro nome para a consciência - sobretudo quando nos damos conta de que a "essência existencial" é a responsável por fundamentar o fato de que podemos "ter consciência de algo". "Toda consciência pressupõe a existência pensada ek-staticamente como a essentia do homem, significando então essentia aquilo que o homem é (west), enquanto ele é (ist) homem"363. Afinal, por qual outro motivo - perguntará Heidegger - a consciência (Bewußt-sein) traria em seu nome o "Ser" (-sein) se não fosse para marcar sua essência existencial, sua carência do existir?

Perguntávamos, então, qual era o modo de Ser do ente que permitia-nos contemplar o Ser. Entendemos agora que este modo de Ser é a insistência em existir, em estar sempre "aí", sendo lançado "para fora". Entretanto, não nos detenhamos nesse ponto; tratemos de observar com maior acuidade o "transcender" e algo ainda se revelará. Pois, sendo de modo que ultrapassa a si mesmo (über sich hinaus), o Dasein se lança forçosamente num mundo que "está em certo sentido mais 'para fora' do que todos os objetos": um "para fora" que o impede de partilhar "do modo de ser simplesmente dado (das Vorhandensein)" e faz com que exista enquanto componente estrutural da própria abertura da transcendência ${ }^{364}$. Isto significa dizer que, se o Dasein é o transcendente, será com ele transcendente também o mundo. E é por isso que na interpretação de si mesmo o homem concreto não hesita em reconhecer que o mundo é parte de sua constituição fundamental e que ele "se compreende a partir de um mundo" (sich aus einer Welt verstehen). "Pertence essencialmente ao Dasein: ser em um mundo"365 - e com esta condição Heidegger já poderá bradar sem receio que a Existenz se descortina como Serno-mundo. Mas justamente como Ser-no-mundo? Tomá-lo desta maneira não seria aprofundar uma fissura que poderia levar ao naufrágio da circunscrição da primazia? Não estaríamos, uma outra vez, arrastando o Dasein para o território do "ente simplesmente dado"? Muito pelo contrário, pois o "Ser-em” (In-Sein) do Ser-no-mundo nada tem a ver

\footnotetext{
${ }^{362}$ Idem, Einleitung zu: “Was ist Metaphysik? “, in: Wegmarken, GA 9, p. 374.

${ }^{363}$ Idem, Ibidem, GA 9, p. 374-375.

364 “O modo de Ser do mundo não é o ser simplesmente dado dos objetos, mas o mundo existe". Idem, Die Grundprobleme der Phänomenologie, GA 24, §20, p. 424-425.

${ }^{365}$ Idem, Sein und Zeit, §4, p. 13.
} 
com o sentido em que um "ente simplesmente dado" se encontra no interior do outro: a água encontrada no copo ou o banco encontrado nessa sala não trazem em si nenhum traço existencial; sua relação é simplesmente categorial, são entes que partilham o mesmo modo de Ser e estão espacialmente determinados por um "dentro de...” (Sein in...). Ora, o "Ser-em" já não destaca a interioridade do "dentro de...", mas designa um habitar o mundo ao qual se está habituado, sem que isto reflita no fato de que um ente esteja situado noutro ente; "Ser-em" é, antes de tudo, um "Ser-junto-a". Portanto, Ser-no-mundo consiste sempre num "Ser-junto-ao-mundo": "o Dasein nunca é 'a princípio'um ente livre do 'Ser-em', que as vezes cede ao capricho de assumir uma relação com o mundo"366. Noutras palavras, reconhecer que o modo de Ser do Dasein repousa no "Ser-no-mundo" é saber que sua abertura é co-originária à abertura do mundo e que ele é inelutavelmente sua facticidade. Desde então, já não se poderá dizer que o "conhecer" (Erkennen), tal como quer a teoria do conhecimento, determina nossa relação primordial com o mundo. Uma constatação que certamente não agradará a Husserl: a partir de agora, o conhecimento não passará de um modo de Ser do Dasein cujo fundamento se encontrará em seu modo de Ser originário, o "já-sempre-Ser-junto-a-um-mundo" (Immer-schon-beieiner-Welt-sein). Em oposição à fenomenologia transcendental, a analítica existencial irá propor que o "conhecer" é antecedido por uma relação que nada lhe deve e que o funda. “Conhecer não é uma relação colocada num ente que ainda não 'tem' mundo, que estaria livre de toda relação com o mundo, mas conhecer é sempre um modo de Ser do Dasein sobre o fundamento de seu já-Ser-junto-ao-mundo (Schon-sein-bei der Welt) ${ }^{\text {"367 }}$. E para aqueles que ainda insistiam em associar o "conhecer" a uma teoria do conhecimento, Heidegger faria questão de rememorar que "não está prescrito em parte alguma que este deveria ser um Erkenntnisproblem"368. O que não significa, de maneira nenhuma, negar a problemática do conhecimento desde o princípio. Não se trata disso. Na verdade, o que se pretende frisar é o fato de que o "conhecer" deve ser observado a partir do sentido de Ser que o precede, isto é, deve ser entendido como um modo de Ser do Dasein. Enquanto um modo de Ser, ele não será o único, nem mesmo o fundamental. Afinal, conhecendo ou não conhecendo, o Dasein sempre será junto-ao-mundo. É por isso que a famigerada passagem da Krisis, segundo a qual um "fora" em geral é privado de sentido, só poderá

\footnotetext{
${ }^{366}$ Idem, Ibidem, §12, p. 57.

${ }^{367}$ Idem, Prolegomena zur Geschichte des Zeitbegriffs, GA 20, §20, p. 217.

${ }^{368}$ Idem, Ibidem, GA 20, §20, p. 218.
} 
soar como um exacerbado idealismo aos ouvidos de Heidegger ${ }^{369}$. Pois o Dasein, em sua constituição fundamental, é sempre "fora" (draußen) - e se há aí alguma "interioridade" (drinnen), é somente aquela de Ser-no-mundo ${ }^{370}$.

Começamos então a vislumbrar como se orquestra o deslocamento pelo qual outrora clamávamos, a passagem ontológica do ego para o sum. Delineemos, diz Heidegger, o primeiro esboço do modo de Ser desse ente que atende pelo nome de Dasein - e com ele vai se anunciar que, se ego sum, o sum se traduz por "eu-sou-em-ummundo"371. Mas diante dessa boa nova, o que restará para o velho ego (dito ser até então a mais indubitável de todas as doações) nesse território regido pela analítica da existência? Restará pouco, é verdade, pois agora é preciso admitir, talvez para o profundo pesar de Descartes e Husserl, que o ego deixa de ser uma necessidade "substancial" do ente por revelar-se incapaz de oferecer uma resposta à pergunta pelo "quem" (Werfrage) do homem. E se, doravante, Heidegger nos proíbe de adotar como "ponto de partida a doação formal do eu", é devido à definição já obtida acerca do modo de Ser do ente da primazia: sob nenhuma circunstância o Dasein pode ser tomado pelo ego porque a noção de Serno-mundo ensina que a determinação de um sujeito "sem mundo" é meramente folclórica. Além disso, essa associação não poderá ser senão arbitrária a partir do momento em que compreendemos que o Dasein não consiste em nenhum "eu-isolado", mas que "no Serno-mundo já está aí com os outros" - afugentando, desde o princípio, toda a possibilidade de solipsismo:

“A princípio, somente eu sou no mundo ou somente o 'eu'é dado sem o mundo. Com a recusa deste começo e com a descoberta do Ser-no-mundo não pode ser proferido nenhum discurso sobre o isolamento do eu e, portanto, sobre o 'somente eu estou no mundo" 372 .

\footnotetext{
${ }^{369}$ Edmund Husserl, Krisis, §18, p. 82. "Ela [a subjetividade transcendental] é o universo do sentido possível, assim que um exterior é certamente um absurdo (Unsinn)". Idem, Cartesianische Meditationen, \$41, p. 117.

370 Idem, Sein und Zeit, §13, p. 62.

371 "Ao invés disso, Descartes diz: cogitationes são simplesmente dadas e, nelas, também um ego como res cogitans desmundanizada é simplesmente dado". Idem, Ibidem, §43b, p. 211.

372 Idem, Prolegomena zur Geschichte des Zeitbegriffs, GA 20, §26a, p. 327. Tudo se passa de maneira muito distinta da descrição da fenomenologia husserliana: "Deve-se atentar bem ao fato de que, na passagem do meu Ego para o Ego em geral, nem a efetividade nem a possibilidade de uma circunscrição (Umfang) dos outros é pressuposta”. Edmund Husserl, Cartesianische Meditationen, §34, p. 106.
} 
Todavia, não poderíamos supor, concedendo benevolentemente às teorias solipsistas, que apenas partindo da "distinção e do isolamento do "eu" seria possível acessar o "outro"? Ora, somente teria cabimento concordar com esta possibilidade se o "outro", no interior da analítica existencial, permanecesse ancorado a determinações tradicionais. Mas este, evidentemente, não é o caso. Nas páginas de Ser e Tempo, a descrição dos "outros” não decorre de um "eu que se destaca" e os concebe como "todo o resto além de mim", mas é o reconhecimento daquele que, "na maior parte das vezes, não se diferencia e entre os quais também se está" ${ }^{\text {373 }}$. Como não há ali nenhuma referência a um ego que emerge da apreensão primária de si mesmo, também não haverá uma doutrina que dele diretamente deriva: antes de ser um ente simplesmente dado, o "outro" que "também-está-aí-comigo" se manifesta como um ente que partilha de meu próprio modo de Ser, o Ser-no-mundo. Se o "outro" não é “coisa", mas é um ente "tal como eu sou”, não nos causará nenhuma surpresa a afirmação de que o compreendemos da mesma maneira pela qual nos compreendemos, "a partir do mundo" (aus der Welt her); também não deverá nos espantar o fato de Heidegger apresentar o "com" e o "também" (do "ser-também-comigo") como existenciais. Vem daí, portanto, a constatação de que este "Ser-com" (Mitsein) nada tem a ver com a ôntica presença do “outro", mas é uma determinação ontológica do próprio Dasein: sempre reside em seu Ser a compreensão do "outro" (pouco importando se ele está presente ou ausente), tornando o "Ser-com um constituinte existencial do Ser-nomundo" 374 . Fundamentalmente avesso a todo solipsismo privado de mundo, esse é o modo de Ser do $\theta \alpha \nu \mu \alpha \sigma \tau$ ì $\nu$ ǒ $\nu$ : Ser-no-mundo enquanto Ser-com.

\section{III - A Disposição}

No início de Ser e Tempo já se afirmava que o Dasein, por não partilhar do modo de Ser dos demais entes, exigia uma distinta via de acesso para sua investigação ontológica. Ao questionarmos qual seria este caminho, talvez fossemos tentados a crer (por obra e graça da aura de primazia na qual este ente está envolto) que o princípio da compreensão estaria numa "diferença" marcante cravada no coração da própria existência enquanto modo de Ser. Mas esta crença, dirá Heidegger, não passa de uma suposição

\footnotetext{
${ }^{373}$ Idem, Sein und Zeit, §26, p. 118.

374 “O próprio Dasein só é possuindo a estrutura essencial do Ser-com, enquanto co-Dasein (Mitdasein) que vem ao encontro dos outros". Idem, Ibidem, p. 121 e 125.
} 
descabida que não poderia estar mais longe da verdade. Afinal, "o Dasein não deve ser interpretado, no ponto de partida da análise, na diferença de um existir determinado, mas deve ser descoberto na indiferença na qual se dá primeiramente e na maior parte das vezes" 375 . E esta "indiferença" - que carrega o nome de cotidianeidade - somente poderá ser encontrada no Ser-com (Mitsein) o "outro" e num mundo que com ele se compartilha (Mitwelt). Pois muito embora o Dasein se inquiete constantemente com a necessidade de se afastar e se diferenciar de seus pares, na convivência cotidiana ele sempre estará sob o senhorio (Botmäßigkeit) dos "outros", quer dizer, "não será ele mesmo, visto que os outros lhe tomam o Ser". "Outros" que de forma alguma são determinados, mas que podem ser "outros" quaisquer. E se os chamamos de "outros" é apenas para encobrir nosso próprio pertencimento existencial a eles. Nós também somos partícipes dos "outros" nesse mundo comum que se abre: eles são - e nós mesmos somos - aqueles que aí estão; o "outro" que nos sorve é o impessoal (Das Man) em toda sua força. Neste sentido, se há uma via de acesso à resposta de uma pergunta pelo Ser, ela se manifesta na indiferença oriunda da Diktatur do impessoal, deste modo de Ser que se atravessa com total discrição (Unauffälligkeit) porque nele as determinações são todas espelhadas: "nós nos divertimos como se (man) diverte, nós lemos, vemos e julgamos sobre literatura e arte como se vê e julga" - nós até mesmo nos afastamos e nos retiramos da turba que parece não se distinguir tal como se afasta e se retira ${ }^{376}$. Trata-se então do território onde o Dasein estará completamente diluído na mediocridade (Durchschnittlichkeit) que o conserva equidistante (in medio) de suas possibilidades próprias e não permite nenhuma exceção ao impessoal. Ali, "toda primazia é silenciosamente esmagada. Todo originário é, da noite para o dia, aplainado como algo há muito conhecido. Tudo o que se conquista com muita luta torna-se banal. Todo segredo perde sua força" ${ }^{\text {377 }}$. Em suma, tudo se passa como se todos estivessem inteiramente nivelados (Einebnung) e como se a decisão (Entscheidung) estivesse ausente: para o impessoal, não há nada que não seja pressuposto, bem como não há juízo que não seja meu sem ser também de todos os demais; como tudo está aberto a todos, tudo é "público" (Öffentlichkeit) ${ }^{378}$. Isto significa dizer que, em sua lida cotidiana, o Dasein não contará com nenhum encargo, nem decidirá pelo Selbst de

\footnotetext{
375 Idem, Ibidem, §9, p. 43.

${ }^{376}$ Idem, Prolegomena zur Geschichte des Zeitbegriffs, GA 20, §26b, p. 336-337; Sein und Zeit, §27, p. 126.

377 Idem, Sein und Zeit, §27, p. 127.

378 "O público obscurece tudo e toma como conhecido e acessível a todos o que é assim encoberto". Idem, Ibidem.
} 
seu Ser? Sem dúvida. E é justamente por isso (por privar-se de ser aquilo que pode ser) que ao perguntarmos quem é este Dasein cotidiano, a resposta só poderá ser "ninguém": como cotidianamente não há a quem possamos nos referir de maneira específica, ninguém é responsável por qualquer coisa que possa ocorrer ou por qualquer discurso que venha a ser proferido. Este ninguém já simboliza, portanto, a queda (Verfallen) do homem. Entretanto, não nos deixemos enganar pela terminologia, adverte Heidegger: não há na queda nenhuma remissão adâmica que faça a analítica existencial tomar ares de teologia. Que o Dasein esteja na condição de decaído, apenas aponta para o fato de que está perdido no impessoal, que fora tentado a supor que havia alguma autenticidade e completude num cenário no qual tudo é impróprio; para ele, há aí uma "tranquilidade (Beruhigung) que assegura que ‘tudo está em ordem' e que todas as portas estão abertas"379. Padecendo desta tentação à queda, ele se entrega aos seus desígnios porque se tranquiliza ao encontrar um recanto onde toda compreensão está dada de antemão.

A cotidianeidade será então a passada inicial de todo Dasein no caminho de sua existência. Sendo lançado ao mundo, ele habitará esse forte da mediocridade que o protege do "fracasso" da apropriação dos entes e viverá na placidez do claustro da indiferença, onde nada mais do que o mesmo será aberto na "fala" (das Gerede) dos que aí estão. Em outras palavras, é desta maneira que Heidegger não cansará de rememorar que estamos, desde o princípio, imersos no vulgo. Mas que isto não nos leve a pensar que esse "modo de acesso", por ser tal como é, traga consigo apenas indicações puramente negativas. Se assim fosse, jamais poderíamos dizer sem receio que é na esfera cotidiana que aprendemos a conhecer muitas coisas - talvez mais do que gostaríamos, uma vez que não poucos homens parecem jamais ultrapassar esta compreensão medíocre. Quanta ingenuidade, portanto, em supor que o Dasein é sempre lançado "diante da livre terra do 'mundo"" e que contemplará apenas aquilo que vem ao seu encontro. Na verdade, "o Dasein - decreta Heidegger - nunca pode subtrair-se a essa interpretação cotidiana na qual ele cresce" ${ }^{380}$; mesmo que nos recusemos a admitir, a cotidianeidade sempre figurará como um pressuposto do Ser-no-mundo. E será nela, a partir dela e contra ela (in ihr, aus ihr und gegen sie) que a compreensão autêntica irá se consumar: "a existência própria não é nada que paire sobre a cotidianeidade decaída, mas existencialmente é apenas uma

\footnotetext{
${ }^{379}$ Idem, Ibidem, §38, p. 177.

${ }^{380}$ Idem, Ibidem, $\$ 35$, p. 169.
} 
apreensão modificada desta" 381 . Assim, se esta é a tela na qual os traços da ontologia fundamental são delineados, cabe então perguntar: partindo do modo de Ser da cotidianeidade, qual rumo é necessário tomar para, finalmente, aportarmos na tão buscada determinação do Ser do ente? Ora, a resposta exigirá que entendamos, antes de tudo, que “o Dasein somente pode decair porque para ele está em jogo o Ser-no-mundo compreensivo-disposto (das verstehend-befindliche In-der-Welt-sein) ${ }^{\prime 382}$. E isto quer dizer que, se é certo que uma compreensão pública e medíocre já exerce sobre nós sua dominação, ofertando previamente o "que" (Was) e o "como" (Wie) das coisas, também é certo o fato de que tal "exercício de poder" somente poderá ocorrer porque a disposição (Befindlichkeit) a fundamenta. Mas o que vem a ser esta “disposição”?

Tanto os Prolegômenos para a história do conceito de tempo quanto Ser e Tempo irão declarar que a disposição nada mais é que a estrutura existencial originária que situa (befinden) e abre o Dasein para o mundo, "é o Apriori para o descobrimento (Entdecktheit) e para a abertura (Erschlossenheit)" - ou seja, é aquilo que onticamente nos habituamos a denominar Stimmungen, as "afecções" ou "humores" que nos acometem enquanto Ser-no-mundo ${ }^{383}$. Sobre ela, Heidegger dirá que aí está para nos diferenciar essencialmente da estrutura de Ser do "ente simplesmente dado" - pois se é verdade que, sendo, nós sempre nos "situamos" ou "dispomos" (befinden), "uma pedra nunca se 'situa', mas é dada de maneira pura e simples (lediglich vorhanden)" ${ }^{384}$. Uma vez que somos no modo de Ser-no-mundo, apenas somos porque a "disposição" provoca esta abertura, determinando como somos e nos tornamos: se Pedro é o que é, é graças a afecção que o situa num mundo que se descobre; se Paulo é o que é, repitamos, é também graças a isto; mesmo o "impessoal” quando é o que é, ele o será por tal razão... Nesse sentido, a “disposição" surge como a estrutura e o modo genuíno de Ser que possibilita o puro "o que é" $(D a \beta)$ a partir do qual o Da-sein se manifesta em seu aí $(D a)$. Um $D a \beta$ que, a bem dizer, não carregará a acepção de seu homônimo aventado pela fenomenologia transcendental: ele não fará eco ao "que" categorial do ente simplesmente dado, nem pertencerá à nenhuma "factualidade" (Tatsächlichkeit); este "que" da facticidade (Faktizität) irá nos remeter, antes de tudo, à determinação existencial do ente em seu modo de Ser, sem jamais significar o factum brutum encontrado na intuição. Além disso,

\footnotetext{
${ }^{381}$ Idem, Ibidem, $\$ 38$, p. 179.

382 Idem, Ibidem.

${ }^{383}$ Idem, Prolegomena zur Geschichte des Zeitbegriffs, GA 20, §28a, p. 354; Sein und Zeit, §29, p. 134.

${ }^{384}$ Idem, Ibidem, GA 20, §28a, p. 352.
} 
a disposição se afastará ainda mais da doutrina fenomenológica tradicional por não poder ser considerada "pela medida da certeza apodítica de um conhecer teórico do puro ente simplesmente dado" "385. É por isso que Heidegger não permitirá que aproximemos o modo de Ser do Dasein do modo de Ser da consciência absoluta. Pois se a disposição não se deixa confundir com o "apreender" (Erfassen) é porque ela não guarda nenhum parentesco com a reflexão imanente do domínio das puras vivências: antes de ser um "refletir", ela é um “ascender" (Aufsteigen) da própria afecção. Contudo, não pensemos que esta crítica proponha a abolição do "apreender" do território da analítica existencial - o que certamente seria absurdo, visto que se trata de um modo de Ser do homem. Com ela, pretende-se apenas ensinar que o "apreender" do conhecimento não é aquilo que há de mais fundamental na estrutura ontológica. A verdade é que algo sempre o antecede e o determina: consumar uma reflexão - garante Heidegger - somente é possível ao passo que uma afecção permite a abertura de uma tal possibilidade. Disposição é, portanto, a abertura, não a apreensão; ela não é um sinônimo para a intencionalidade, mas aquilo que a possibilita: "a afecção já abriu o Ser-no-mundo como um todo e fez possível, antes de mais nada, um 'dirigir-se para...' (Sichrichten auf...)"386.

Donde se vê claramente que sequer a fenomenologia, com seu método inabalável,

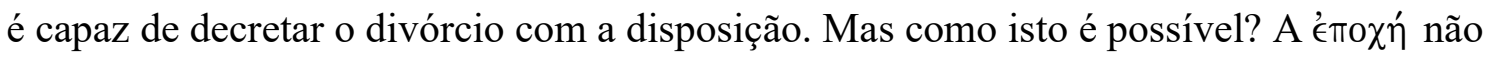
nos proibia de recorrer a qualquer pressuposto que viesse a perturbar o rigor da ciência? A eversio não vinha à luz justamente para nos livrar dos pré-juízos? Ora, quando a fenomenologia colocava em curso sua retórica, e nos convidava a uma nova visada (orientada pela exclusão de pressupostos), ela se furtava ao caráter fundamental da ontologia: não apenas ignorava a impossibilidade de herdar a eversio sem transformá-la num ato de fé, mas também se esquecia que mesmo "a mais pura $\theta \epsilon \omega \rho i ́ \alpha$ [teoria] não deixava para trás toda afecção (Stimmung)" ${ }^{\text {387 }}$. Seria então um exagero e uma ingenuidade pueril a suposição de que a eversio poderia prescindir da disposição. Pois, na condição ideal de que todos os pressupostos pudessem ser perfeitamente excluídos, a teoria

\footnotetext{
385 "O que da facticidade nunca será encontrado numa intuição”. Idem, Sein und Zeit, §29, p. 135-136. ${ }^{386}$ Idem, Ibidem, §29, p. 137.

387 Idem, Ibidem, §29, p.138. Como a disposição sempre faz com que uma afecção anteceda e abra as possibilidades do Dasein, seria um contra-senso supor que possa haver aí uma є̇то $\chi$ heideggeriana. Por

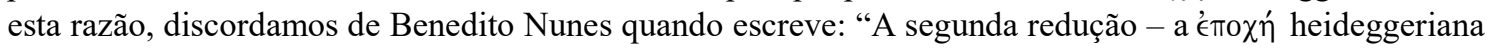
- levanta ou suspende a certeza do Cogito, em proveito da imediata e obstinada incerteza do mundo, a que o sujeito se encontra aderido antes de descobrí-la reflexivamente. Colocado o Eu entre parênteses, é a adesão pré-reflexiva ao mundo, anteposta ao Cogito, e proposta à sua evidência, o que o Dasein expressa". Cf. Benedito Nunes, Passagem para o poético. Filosofia e poesia em Heidegger, p. 69.
} 
apreenderia o Vorhanden "em sua pura forma" (in seinem puren Aussehen) caso o Dasein se demorasse tranquilo (im ruhigen Verweilen bei...) junto ao ente. E esta "tranquila demora" somente era obtida quando a primeira meditação trazia ao centro da cena uma "tonalidade afetiva" (Gestimmtheit) que apontava para o ens certum e permitia reconhecer o ens qua ens por meio da certitudo resultante do encontro com o cogito, ergo sum. Assim, toda determinação (Bestimmtheit) da fala cartesiana, do clare et distincte percipere, tinha sua origem na afecção que fazia da eversio uma "positiva concordância (Zustimmung) com a certeza": a ânsia de ao menos uma vez na vida tudo fazer ruir desde o fundamento

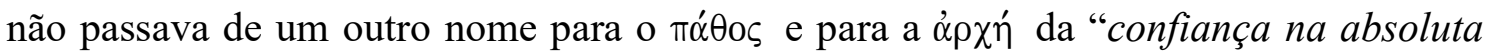
certeza do conhecimento sempre alcançável" ${ }^{388}$. E não era exatamente isso que Husserl - numa espécie de "ligeiro" deslize de sua argumentação - confessava no primeiro livro de Ideias, ao afirmar que "a fenomenologia nascente tem de contar com a afecção fundamental (Grundstimmmung) do ceticismo"? ${ }^{389}$ Diante disso, observa Heidegger, nota-se quão fantasiosa é a pretensão de assenhorar-se das afecções graças ao expurgo da

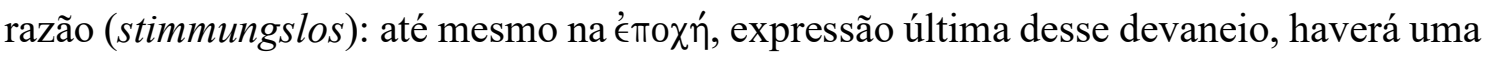
“contra-afecção" (Gegenstimmung) a guiar-lhe os passos, quer dizer, sempre haverá uma "tonalidade afetiva" da disposição a abrir o mundo e as possibilidades para o Dasein ainda que a possibilidade aberta seja uma excêntrica orientação parentética. Em outras palavras, como "a percepção imanente das vivências carece de um fio condutor ontologicamente suficiente", a disposição aí estará "não somente para caracterizar o Dasein de maneira ontológica, mas terá simultaneamente, com base em sua abertura, uma significação metodológica fundamental para a analítica existencial”390.

É preciso, pois, dar razão a Bento Prado quando - ao comentar a obra heideggeriana - nos relembra que "não estamos portanto diante de um conhecimento desinteressado" e que "só filosofamos quando, de algum modo, somos arrebatados, envolvidos pela filosofia através de uma particular tonalidade afetiva" ${ }^{391}$. E a julgar pela precisão sempre presente em suas palavras, coloquemos então a questão: se é certo que uma afecção sempre se encontra na base da compreensão das possibilidades do Dasein, qual delas o abrirá à compreensão do Ser? Perguntar-se-à se não é a alegria a afecção responsável por nos conduzir ao bom termo da investigação ontológica. Ora, muito

\footnotetext{
${ }^{388}$ Martin Heidegger, Was ist das - die Philosophie?, in: Identität und Differenz, GA 11, p. 27.

${ }^{389}$ Edmund Husserl, Ideen I, §63, p. 136.

${ }^{390}$ Martin Heidegger, Sein und Zeit, $\$ 29$ e $\$ 39$, p. 139 e 181-182.

${ }^{391}$ Bento Prado Júnior, Ipseitas, p. 105.
} 
embora Heidegger seja excessivamente econômico na passagem que lhe dedica em $O$ que é metafísica?, não hesitará em dizer que a alegria é incapaz de cumprir esse papel porque não faz senão nos situar em meio à totalidade do ente; enquanto afecção fundamental, ela serve melhor à investigação de Bergson do que à analítica existencial ${ }^{392}$. Talvez o tédio? Talvez - porém não o tédio em sua determinação vulgar, nascido da leitura de um livro modorrento ou do ócio medíocre, e sim o tédio profundo que nos arrasta "cá e lá como uma bruma silenciosa nos abismos do Dasein" ${ }^{\text {"393 }}$, que reúne coisas e homens na mais pálida indiferença; uma afecção que Jean-Luc Marion e Benedito Nunes associarão à morne incuriosité baudelairiana, e que não deixará de rememorar os versos de Além-tédio de Mário de Sá-Carneiro:

\section{"Ecoando-me em silêncio, a noite escura}

Baixou-me assim na queda sem remédio;

Eu próprio me traguei na profundura,

Me sequei todo, endureci de tédio.

\section{E só me resta hoje uma alegria:}

É que, de tão iguais e tão vazios,

Os instantes me esvoam dia a dia

Cada vez mais velozes, mais esguios..."

No entanto, Heidegger não tardará em dizer que tampouco essa Stimmung tão singular do tédio será capaz de proporcionar o acesso ao Ser: basta experimentá-la para que tudo se desvaneça no desinteresse e para que sobrevenha, mais uma vez, o ente em sua totalidade (das Seiende im Ganze). Mas se sequer o tédio profundo poderá abrir o caminho para a ontologia fundamental, qual afecção tomará para si o encargo da tarefa?

Aos olhos de Heidegger, a afecção fundamental (Grundstimmung) que nos conduzirá ao Ser do ente não será outra senão a angústia. Seria então necessário que estivéssemos submetidos a um certo temor para que a ontologia fundamental viesse,

\footnotetext{
${ }^{392}$ Idem, Presença e campo transcendental:consciência e negatividade na filosofia de Bergson, p. 37.

${ }^{393}$ Martin Heidegger, Was is Metaphysik?, in: Wegmarken, GA 9, p. 110.

394 Ou ainda a estrofe de Sá-Carneiro, escrita em fevereiro de 1914, que Bento Prado Júnior utiliza como epígrafe de Erro, Ilusão, Loucura e Ipseitas: "Eu não sou eu nem sou outro/Sou qualquer coisa de intermédio/Pilar da ponte do tédio/Que vai de mim para o Outro". Cf. Jean-Luc Marion, L'angoisse et l'ennui: pour interpréter 'Was ist Metaphysik?', p.126; Benedito Nunes, Passagem para o poético. Filosofia e poesia em Heidegger, p. 108.
} 
finalmente, a ocupar seu lugar na narrativa filosófica? Longe disso, dirá Heidegger, pois temor algum permitirá que o Ser possa se revelar. Afinal, se é verdade que tememos, isto sempre ocorre diante deste ou daquele ente determinado que nos amedronta. Amedrontados, sabemos determinar o que nos amedronta e o descobrimos, sem exceção, como um ente intra-mundano. E na aspiração de que possamos ser salvos disto que tememos, possibilitamos a abertura de uma totalidade do ente kopflos - que, muito similar àquela aberta pelo tédio e pela alegria, talvez possa nos livrar desse temor. Donde se vê em que "a angústia será fundamentalmente diferente do temor"395: quando nos angustiamos, isto que nos ameaça nunca é algo determinado; o ameaçador surge sempre como muito próximo, estreitando (já que, segundo sua etimologia, a angústia não poderia fazer senão estreitar - angustum, beengen), mas ao mesmo tempo como aquilo que não está em parte alguma (nirgends). A indeterminação é sua regra, e é ela que nos causa total estranhamento. Um estranhamento (Unheimlichkeit) que nos faz verdadeiros exilados em nosso país de origem, Daseins que estão "apartados de sua morada" (Nichtzuhause-sein). Mas o que seria, por sua vez, um "estar na morada" (Zuhause-sein) enquanto condição da qual a angústia nos retira? "Estar na morada" nada mais é do que estar acomodado na certeza tranquila que nos oferta o cotidiano em sua mediocridade: “estamos na morada" quando a compreensão e a interpretação são, muito comodamente, já dadas como sendo de todos e de ninguém; também "estamos na morada" porque, em vez de fugirmos do ente intra-mundano em direção ao Ser, fugimos para o ente intramundano em direção à perda no impessoal. Nesse sentido, abandonar a morada é deixar o conforto de estar lançado ao ente para "fugir" na direção oposta. E uma vez fora da morada poderemos provar a "ameaça" que não está "aqui” ou "lá", mas que está "aí", tão próxima que conseguiremos "sentir sua respiração" enquanto rouba-nos o ar - quer dizer, poderemos saborear a sensação de que o indeterminado que nos angustia é o próprio Nada: "de fato, o Nada mesmo - enquanto tal - estava aí", pois "o diante-de-que (Wovor) da angústia é o Nada" ${ }^{\text {396 }}$. Mas não nos deixemos enganar pela terminologia: o Nada no qual aporta a analítica existencial não tem a ver com as definições corriqueiras de "negação" (Verneinung) ou de "aniquilamento" (Vernichtung) do ente. Abandonemos por um instante - recomenda Heidegger - os ensinamentos que outrora obtivemos em nossas lições sobre lógica, pois, somente assim, compreenderemos que o Nada tem como único

\footnotetext{
${ }^{395}$ Martin Heidegger, Was is Metaphysik?, in: Wegmarken, GA 9, p. 111; Sein und Zeit, §30, p. 140-142. ${ }^{396}$ Idem, Was is Metaphysik?, in: Wegmarken, GA 9, p. 110-111; Prolegomena zur Geschichte des Zeitbegriffs, GA 20, §30b, p. 401.
} 
intuito nulificar. E que "o Nada mesmo nulifique" (das Nichts selbst nichtet) não significará senão o fato de que propicia a abertura daquilo que não é o ente intramundano, mas sim daquilo que está ai sem estar em parte alguma, do mundo enquanto mundo em sua própria mundaneidade: “o diante-de-que (Wovor) da angústia é o mundo como tal"397.

Contudo, quando nos angustiamos diante disso que não é Nada e não está em

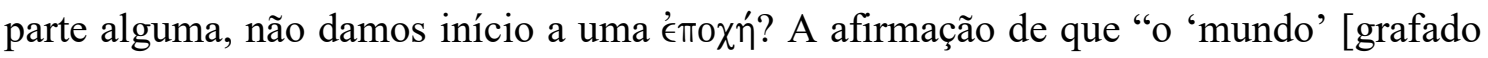
entre aspas, representando a figura do ente intra-mundano] não pode oferecer mais nada, tampouco o Dasein dos outros que aí estão conosco (das Mitdasein Anderer)"398, não seria um armistício tardio que Heidegger assinava com Husserl ao reconhecer o ponto para o qual a angústia nos conduzia? Ora, essa tese apenas faria sentido se concedêssemos inteiramente ao argumento de Jean-Luc Marion e se considerássemos convincente o fato de que "a angústia cumpre uma redução fenomenológica [ao gosto de Husserl, é importante frisar] conduzindo o ente em sua totalidade de volta para o Ser" ${ }^{399}$. Mas nenhuma passagem escrita por Heidegger nos permite julgar tal interpretação como verdadeira; ao contrário, a suposição de que a angústia esteja precisamente alinhada ao método da fenomenologia transcendental parece somente indicar que mesmo o mais beato de todos os santos ainda pode incorrer no mais horrendo de todos os pecados. Pois se já não bastasse o relato sobre a impossibilidade de uma eversio pura, sem qualquer afecção que lhe estivesse na base, Heidegger ainda faria questão de ensinar que a angústia não carecia de nenhuma meditação incomum ou de uma radical mudança de orientação, mas que - independente de vontade ou esforço - estava sempre à espreita, podendo saltar e acometer o Dasein na raridade que lhe caracteriza:

“O angustiar-se abre, de maneira originária e direta, o mundo enquanto mundo. Não é primeiramente a reflexão que abstrai do ente intra-mundano para só então pensar o mundo e, por conseguinte, fazer surgir a angústia; mas é a angústia que abre, antes de tudo, o mundo enquanto mundo como modo da disposição"400.

\footnotetext{
${ }^{397}$ Idem, Sein und Zeit, §40, p. 187; Was is Metaphysik?, in: Wegmarken, GA 9, p. 113-114.

${ }^{398}$ Idem, Sein und Zeit, §40, p. 187.

${ }^{399}$ Jean-Luc Marion, Beings and the Phenomenon, in: Reduction and Givenness, p. 73.

${ }^{400}$ Martin Heidegger, Sein und Zeit, $\$ 40$, p. 187. Ou em $O$ que é metafísica?: “A angústia originária pode despertar a qualquer momento no Dasein. Para isto ela não carece de nenhum despertar por meio de um acontecimento inabitual". Idem, Was is Metaphysik?, in: Wegmarken, GA 9, p. 118.
} 
Não há, portanto, nenhuma exclusão de pressupostos que visa tudo colocar entre parênteses; o que há é uma afecção "pressuposta", um estreitamento com a indeterminação que abre o "mundo enquanto mundo" como o "diante-de-que" da angústia. E como o mundo - declara Heidegger - pertence "de maneira ontologicamente essencial" ao Ser do Dasein, pode-se muito bem dizer que o "diante-de-que a angústia se angustia, é o Ser-no-mundo mesmo" "401. Assim, é graças a esse "estreitamento" premente que o Dasein se abre para si mesmo como o Ser-no-mundo, ou seja, abre-se não apenas como aquilo "diante-de-que" (Wovor) a angustia se angustia, mas também como aquilo "pelo-que" (Worum) a angustia pode se angustiar; "estreitando-se", o Dasein se lançará à única "coisa" à qual poderia ser lançado: "o diante-de-que" e o "pelo-que" a angústia se angustia, "seu próprio poder-Ser-no-mundo (sein eigentliches In-der-Welt-seinkönnen)". "O diante-de-que (Wovor) e o pelo-que (Worum) da angústia são ambos o Dasein mesmo; ou dito de modo mais preciso, o Faktum que eu sou no sentido do nu Serno-mundo" ${ }^{402}$. Daí se entende porque a angústia é descrita em Ser e Tempo como uma Vereinzelung: ao subtrair o Dasein do impessoal, lançando-o de volta a si mesmo, a angústia o singulariza; ela o arrasta da dispersão da compreensão cotidiana para o Serno-mundo que lhe é "mais próprio" e o traz à existenziale Selbigkeit, no encontro da abertura e do aberto como sendo o mesmo. Mas essa ideia de singularização não reviveria a velha tese do solipsismo? De fato, "singularizando-se" no estreitamento consigo mesmo, o Dasein experimentará o solus ipse. Todavia, adverte Heidegger, o conceito já não faz eco à nenhuma concepção clássica de "um sujeito-coisa isolado no inofensivo vazio de um acontecer sem-mundo" ${ }^{403}$. No interior dos marcos da analítica existencial, o solipsismus passa a ter um "sentido extremo" de trazer o homem diante do mundo enquanto mundo e diante de si mesmo enquanto Ser-no-mundo. E será assim, solus ipse, que ele se compreenderá como "ser-possível” (Möglichsein) em seu próprio Ser, quer dizer, compreenderá que na angústia repousa a possibilidade excepcional que abre o horizonte de possibilidades e revela "no Dasein o Ser para o mais próprio poder-ser, o ser-livre para (Freisein für) a liberdade de escolher e acolher a si mesmo" ${ }^{404}$.

Mas para onde aponta essa liberdade de escolha e acolhimento de si que o "solipsismo existencial" acaba por desvelar? Heidegger confessará que "ser-livre para..."

\footnotetext{
${ }^{401}$ Idem, Sein und Zeit, $\$ 40$, p. 187-188.

${ }^{402}$ Idem, Prolegomena zur Geschichte des Zeitbegriffs, GA 20, §30b, p. 402.

${ }^{403}$ Idem, Sein und Zeit, §40, p. 188.

404 Idem, Ibidem.
} 
é aquilo que sempre faz da existência uma aposta incerta na qual algo "está em jogo". No entanto, o que "está em jogo"? Para o Dasein, o que "está em jogo" em seu Ser é o Ser ele mesmo. E que "o Ser esteja em jogo em seu próprio Ser" nada mais significa que o Ser do Dasein sempre se lança diante da possibilidade aberta ou se "projeta" em seu próprio poder-ser. Noutras palavras, quando a angústia nos acomete, ela abre a condição de possibilidade que nos permite ser aquilo que, de fato, somos; enquanto afecção fundamental, ela revela a condição $d e$ possibilidade como condição $d a$ possibilidade (seja ela qual for). Daí Heidegger afirmar que, por meio da "concreção originária e elementar" apresentada na angústia, "o Dasein em seu Ser já antecede (vorweg) a si mesmo"405. Isto quer dizer que $o$ Ser consiste então no anteceder? Sem dúvida, e não há nada mais coerente - etimologicamente coerente - do que isto (pois, se tergiversamos ao étimo do conceito, corremos o risco de embotar a fineza da descrição heideggeriana com o lançamento de uma visada míope sobre a questão). Afinal, se toda possibilidade é um caminho (Weg) e se todo Dasein, enquanto é, traça o caminho na realização da própria possibilidade, não é por acaso que o Dasein em seu Ser antecede (vorweg) a si mesmo: o Ser é o que está diante de (vor-) de todos os caminhos (-weg) e que os abre, a fim de que sejam trilhados. Nesse sentido, a angústia será o caminho que conduz à origem de todos os caminhos - origem esta que os antecederá, bem como antecederá à própria angústia. E se o Dasein é sempre Ser-no-mundo, essa antecedência do Ser será definida como um "anteceder-se-já-num-mundo" (Sich-vorweg-schon-sein-in-einer-Welt). Assim, o Ser deverá ser compreendido como uma "preocupação" (Sorge ou cura) que antecede a totalidade das possibilidades das relações com o ente-intramundano (Besorgen) e com o Outro (Fürsorge). Donde se pode observar, ainda uma outra vez, a razão pela qual a obsessão por uma є̇то $\chi$ heideggeriana será privada de sentido. Pois se é verdade que o Ser é cura, também é certo que o filósofo prosélito da eversio, mais do que qualquer outro, se mostrará incapaz de contemplá-lo porque sua orientação já eliminava, desde o princípio, toda possibilidade de obtenção de uma ontologia autêntica. A passagem gravada no limiar das Meditationes não é fortuita:

${ }^{405}$ Idem, Ibidem, §41, p. 191. 
"Opportune igitur hodie mentem curis omnibus exsolvi, securum mihi otium procuravi, solus secedo, serio tandem et libere generali huic mearum opinionum eversioni vacabo" $" 406$.

Não passa então de uma ideia fantasiosa o fato de podermos nos livrar da "preocupação" servindo-nos da eversio (o que faz com que atribuamos - diga-se de passagem - um outro sentido à carência que a fenomenologia transcendental confessava possuir do conceito de fantasia). Não seria nada menos do que absurdo alcançar o Ser por meio de uma exclusão de pressupostos quando já se reconheceu que no "anteceder-se" da preocupação jaz "o mais originário 'pressupor' (das ursprünglichste 'Voraussetzen'): “porque esse pressupor-se pertence ao Ser do Dasein, devemos 'nós' também 'nos' pressupor enquanto determinados pela abertura" 407 . É por isso que a preocupação jamais poderá significar, “primária e exclusivamente, a relação isolada do 'eu' consigo mesmo" oriunda do método inaugurado por Descartes. Em momento algum ela deixará entrever a teológica mentis immortalitas do ego cartesiano ou os infinitos horizontes de retenção e protensão do reines Ich husserliano na temporalidade transcendental. Afinal, o Ser enquanto cura é essencialmente definido pela facticidade do Ser-no-mundo, é caracterizado por sua própria finitude. E é por compreender e compreender-se em sua inescapável finitude (abrindo antecipadamente a possibilidade própria, irremissível, insuperável e certa da morte) que o Dasein poderá "ouvir a voz do amigo que porta consigo" 408 , a voz do Ser que o interpela e o conclama a ser aquilo que é. Não é estranho, pois, que nem Descartes nem Husserl tenham sido capazes de desvelar o Ser autêntico: mais do que uma visão aguçada, a ontologia fundamental exige uma audição atenta. Portanto, aprendamos a ouvir o Ser, recomenda Heidegger; e, ao ouví-lo, repitamos as palavras de Santo Agostinho:

"Iube, quaeso, atque impera quicquid vis, sed sana et aperi aures meas, quibus voces tuas audiam" $" 409$.

\footnotetext{
406 “É, portanto, em boa hora que, hoje, com a mente liberada de todas as preocupações, no ócio seguro do retiro solitário, dedicar-me-ei por fim, de maneira séria e livre, à essa eversão geral de minhas opiniões". René Descartes, Meditationes, Med. I, §2, p. 20-22.

${ }^{407}$ Martin Heidegger, Sein und Zeit, §44c, p. 228.

408 "O ouvir constitui a abertura primordial e própria do Dasein para o seu mais próprio poder-ser enquanto o ouvir a voz do amigo que o Dasein porta consigo". Idem, Ibidem, §34, p. 163.

409 "Ordena, Te rogo, e impera tudo o que desejas, mas sana e abre meus ouvidos, com os quais eu possa ouvir tuas vozes". Santo Agostinho, Soliloquia, I, 5, p. 12.
} 


\section{Conclusão}

Na origem desse escrito o leitor já se defrontava com a seguinte questão: “como a crítica do remanescente cartesianismo da fenomenologia conduz à autêntica pergunta pelo Ser?" Sem querer aborrí-lo em demasia, que ele nos permita retomá-la também no desfecho; se a repetimos agora é porque ela nos possibilita retraçar o caminho da resposta que lhe ofertamos. Mas de que maneira esta indagação inicial nos presta tal auxílio? Ora, nos termos de sua formulação, ela irá nos rememorar que a compreensão da crítica heideggeriana à filosofia de Husserl exige, antes de tudo, um entendimento prévio dos traços cartesianos da fenomenologia. E é por esta razão que, inicialmente, procuramos investigar este laço responsável por vincular o pensamento fenomenológico às Meditationes de prima philosophia. Seguindo as indicações das Meditações Cartesianas (mais especificamente os desdobramentos da estrutura gramatical do "duplo-quase") e concedendo a devida atenção às palavras de Kierkegaard sobre a natureza da dúvida, pudemos observar como o conceito de eversio não apenas surgia enquanto marca indelével da união, mas também se apresentava como causa de toda ruptura. Pois se é verdade que, em nome do velho rigor, Husserl propunha a exclusão de todos os pressupostos no ato de fundação da ciência primordial, não é menos certo que a filosofia de Descartes acabava por ser atingida pelo processo de "decantação" cognitiva. Ainda que de maneira muito tímida, era justamente este preceito que víamos operar no berço rústico da fenomenologia: em sua tentativa de clarificar a essência da dedução, os esforços dos Prolegômenos à Lógica Pura já assumiam a forma de uma contida purgação em vista da elaboração das condições objetivas do saber. Tentativa incipiente, de fato, mas não infrutífera, uma vez que era graças ao seu primeiro impulso que a necessidade da exclusão de pressupostos obtinha um contorno mais evidente nas Investigações Lógicas. Era ali que Husserl, em aberta oposição às teorias psicologistas, definia a "vivência fenomenológica" como sendo a vivência purgada de todo prejuízo real: fruto de uma "percepção interna adequada", não maculada por qualquer resquício empírico, tal vivência se manifestava em seu caráter propriamente ideal, quer dizer, encontrava a si mesma num processo reflexivo que minava o clássico equívoco da equivalência entre a "coisa que aparece" e o "aparecer da coisa". Mas em que sentido - perguntávamos - uma tese como esta distanciava a fenomenologia da filosofia de Descartes? Ela não fazia senão repetir as célebres passagens da segunda meditação? Certamente não - e a análise da 
quinta investigação nos impedia de subscrever essa falsa aparência de repetição. Afinal, Husserl fazia questão de acentuar que não se constatava, após a dissolução das pressuposições, nenhum ponto arquimediano inerente ao âmbito das vivências. Devidamente perscrutada, a condição subjetiva do conhecimento não revelava nenhum "eu residual" que atuasse como sustentáculo das vivências. Visto que o ego não passava de uma "coisa externa" semelhante a tantas outras, a consciência fenomenológica não compactuava com sua homônima cartesiana: sem ser devedora de um substrato egóico, ela se apresentava como um fluxo ao gosto de Heráclito, um verdadeiro desdobramento sem origem.

Era também por conta do máximo respeito à exigência da eversio que a fenomenologia transitava para sua forma transcendental. Submetendo suas próprias teses à purgação, Husserl notava a insuficiência da noção de "consciência em geral” que opunha à "consciência psicológica" de seus adversários. Aos seus olhos, ambas padeciam de um pré-juízo cartesiano - que, por sua vez, nada mais era do que uma herança transmitida por Galileu: distinguindo-se de modo meramente superficial, tanto uma quanto outra se permitiam circunscrever por um conceito de alma que as enraizava num mundo exterior ao domínio do cogito. Em outras palavras, psicologia e fenomenologia ainda acatavam o dualismo típico da orientação natural do pensamento. Contudo, por que isto constituía exatamente um problema? Porque a cisão da res - lia-se em A ideia da fenomenologia - estava calcada na absurda crença da independência ontológica do mundo e em sua transformação na condição de possibilidade de todo conhecimento. Havia aí, portanto, um pressuposto cujo colapso se fazia necessário. E era nesse ponto - tal como nossa exposição buscou acentuar - que Husserl, impiedosamente, fazia Descartes entrar num cruento embate contra si mesmo. Não somente por servir-se de sua orientação metódica para condenar a injustificável "obviedade" da ideia de um "mundo de corpos fechado sobre si", mas sobretudo por alertar seu patrono - por obra e graça de uma eversio incomparavelmente radical - que a dúvida encontrada ao final da "primeira meditação" era indigna da alcunha de "hiperbólica". Pois, se é certo que a orientação verdadeiramente fenomenológica nos proibia de empregar qualquer juízo transcendente no momento de edificação da ciência rigorosa, nada parecia nos autorizar a conceder qualquer indulgência ao juízo negativo de pretensão universal; se a dúvida era tão "mundana" quanto aquilo que desejava negar, podia-se muito bem entender sua incapacidade de nos livrar do préjuízo de um fundamento telúrico. Vinha daí então a necessidade de que a "exclusão de 
pressupostos" da fenomenologia transcendental (em sua forma maturada) não fosse um "colocar em questão" tipicamente cético, mas um "colocar entre parênteses". Parênteses que reduziam o campo da visada à única esfera de sentido em sua certeza; parênteses cujo claustro tudo retinha, exceto o fluido Ser absoluto da consciência constituinte e seu "ego puro" - outrora perdido nas eivadas Investigações Lógicas, porém solenemente recuperado em Ideias, em oposição ao ego fixo e atrofiado das Meditationes. "O ditado

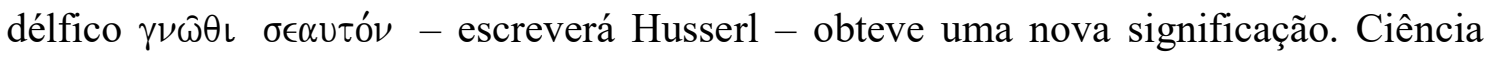

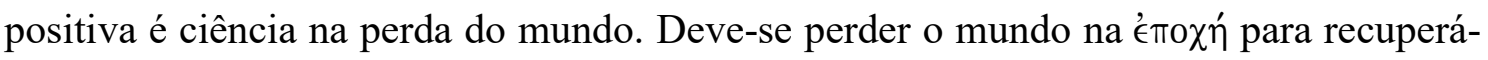
lo em seguida na universal meditação de si. Noli foras ire, diz Agostinho, in te redi, in interiore homine habitat veritas ${ }^{\prime 410}$. Adentrava-se assim, contra Descartes e com ele, o território que o filósofo francês se contentou apenas em apontar; não por acaso, também contra ele e com ele, este novo domínio da consciência transcendental definia-se pela fórmula "nulla 're' indiget ad existendum”. Tal é, sumariamente desenhado, o anticartesianismo da fenomenologia: um ultra-cartesianismo dissimulado. Ou melhor: eis aí o paradoxo envolvendo a herança e o acolhimento do ato de evertere - para o qual o jovem Climacus oferecia a única "resposta" possível a quem tentasse solucioná-10 ${ }^{411}$.

Muito embora a literatura especializada tenha se furtado às considerações deste embrolho no qual Husserl se inseria de bom grado, pouco tardou até que Heidegger identificasse o impasse e dele se servisse na crítica à fenomenologia que se esboçava em seus cursos marbugueses. Partindo da noção de preocupação com o conhecimento conhecido, bem como de seu afã pela clarificação do enigma gnosiológico, a preleção Introdução à pesquisa fenomenológica desde muito cedo fazia questão de rememorar aos aspirantes à fenomenólogo algo que tendiam a esquecer por conveniência: recordava-lhes que toda preocupação, independente do vulto que pretendia adotar, era essencialmente histórica, e que mesmo se vangloriando de estar desenraizada do solo fático-histórico ainda possuía um passado originário. Assim, não se podia compreender a preocupação fenomenológica com o "conhecimento conhecido" apenas restringindo-se à dominação de seus interesses anistóricos, mas era preciso retornar ao seu manancial: "este retorno ao

\footnotetext{
${ }^{410}$ Edmund Husserl, Cartesianische Meditationen, §64, p. 183.

411 "Por fim, sentiu-se seguro de si, seguro de poder realizar o movimento com facilidade. Resolveu então deixar o pensamento agir com todo o peso; pois fazia uma distinção entre a dificuldade do raciocínio e o peso do pensamento (...) Havia reunido novas forças, estava integrado, colocou, por assim dizer, o ombro sob o pensamento e, vejam só, este o sobrepujou; ele desmaiou. Quando voltou a si, quase não se atrevia a voltar a atenção para o pensamento; achava que podia enlouquecer quem não tivesse nervos mais fortes que os seus”. Søren Kierkegaard, Johannes Climacus ou De omnibus dubitandum est, cap. I, §3, p. 54.
} 
Ser próprio da preocupação para a determinação de seu estar-aberto é uma volta à unidade da pesquisa, a qual leva o nome de 'Descartes" ${ }^{\text {"412. }}$. Aos que souberam ouvir as lições de Husserl com esmero, não era surpreendente que a exigência do recuo nos guiasse até Descartes. Mas menos surpreendente era o fato de que a análise heideggeriana do cartesianismo tivesse início pelo conceito de erro, transitasse em direção à preocupação com a certitudo (cogito) e enfim desembocasse no mesmo local onde desembocaria a leitura subsequente da obra de Husserl, isto é, a edificação da ciência unbedürftig que ocuparia furtivamente o lugar de lisonja do Ser no seio da filosofia. É claro que Heidegger não seria ingênuo a ponto de afirmar que as teses das Meditationes e de Ideias não guardavam suas diferenças. Qualquer tentativa de imputar-lhe tais palavras seria, no mínimo, um profundo desconhecimento das etapas de sua argumentação. Bastava a leitura dos Prolegômenos para a história do conceito de tempo (amparada, nesse caso, pelo artigo A época da imagem de mundo) para que se observasse como ali já se reconheciam os desacordos entre as doutrinas do dualismo clássico e da subjetividade dilatada da fenomenologia transcendental. Todavia, a despeito de certas distinções promovidas pela purga desencadeada por Husserl, não se podia deixar de notar - e era justamente isto que Heidegger se empenhava em mostrar - como a mesma eversio que o livrava das amarras da orientação natural acabava por condená-lo com outros pressupostos. Pois, quando bem compreendido, o conceito husserliano de Ser absoluto, em cada uma de suas determinações (apreendido, dado, constituinte e ideal), provava-se incapaz de responder autenticamente a pergunta pelo "Ser do intencional". Contrariando

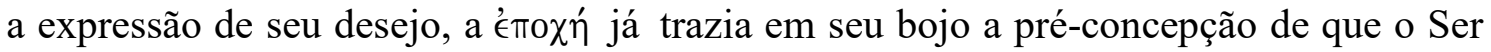
não poderia se manifestar de outra forma senão enquanto Ser-objeto de uma ciência. Era o que Introdução à pesquisa fenomenológica já relatava sobre o pensamento de Descartes:

"Em primeiro lugar, está a ciência e sua possível elevação em questão; em segundo lugar, está o Ser disto que é tratado, assim que, de fato, o conceito de Ser é determinado: Ser como possível domínio-de-ser para a elaboração de uma ciência $(\ldots)^{\prime 413}$.

\footnotetext{
${ }^{412}$ Martin Heidegger, Einführung in die phänomenologische Forschung, GA 17, §19, p. 177.

${ }^{413}$ Idem, Ibidem, GA 17, §46, p. 257.
} 
E é o que se repetirá acerca do pensamento de Husserl em Prolegômenos para a história do conceito de tempo:

“O que é o primeiro na característica da consciência em relação ao seu Ser, é o sentido de uma possível objetividade científica, e não seu Ser especificamente próprio, o qual existe antes mesmo de toda elaboração científica possível e tem seu sentido próprio" ${ }^{\text {414. }}$.

Ora, que a eversio claudicasse em posse do discípulo, sendo ela mesma o pressuposto que jamais poderia ser excluído, já bem o sabíamos desde Kierkegaard. Mas que ela, além disso, arrastava consigo um pressuposto ontológico igualmente danoso, eis aí uma constatação que Heidegger viria a acrescentar. Constatação profícua, diga-se de passagem, uma vez que fazia ruir dois baluartes num só golpe: por um lado, minava o mito da "neutralidade ontológica da fenomenologia" e, por outro, descortinava o ato de trair a própria palavra de ordem de "retorno à coisa mesma" tão logo se assumia a “exclusão de pressupostos" como princípio diretor. Assim, se é verdade que a fenomenologia aceitava mansamente um conceito de Ser que nada tinha de original, tal consentimento só fazia permitir que "a coisa mesma" se apagasse na noite da tradição; como não havia uma "pergunta autêntica pelo Ser", não poderia haver "retorno à coisa mesma" - e isto tornava a doutrina fenomenológica "pretensamente fenomenológica".

Observada pelas lentes heideggerianas, a filosofia de Husserl não distava - do ponto de vista ontológico - da filosofia de Descartes: ao converterem "a preocupação com o conhecimento conhecido" numa "preocupação com a formação de uma ciência", ambas as doutrinas pressupunham o sentido de Ser da objetividade de uma região sui generis e o tomavam pelo Ser verdadeiro. Tudo se passava, portanto, como se os filósofos da eversio, desde o princípio e de maneira inteiramente ingênua (para empregarmos nesta constatação irônica um vocabulário que lhes é caro), cedessem à primazia da teoria e à sua determinação do Ser do ente como substância; tanto as Meditationes quanto o primeiro livro de Ideias não possuíam um conceito de Ser original, mas o entendiam aos moldes do pensamento grego, como um ente "simplesmente dado" que refletia o modo de Ser do próprio mundo. Assim, atribuindo ao Ser dos atos o "Ser no sentido da realidade da natureza" (Sein im Sinne der Realität von Natur), a fenomenologia equiparava-se dogmaticamente àquela história da filosofia que seu método se empenhava em excluir do

${ }^{414}$ Idem, Prolegomena zur Geschichte des Zeitbebriffs, GA 20, §13c, p. 165. 
circuito de considerações: por uma linhagem cartesiana, ela descendia dos antigos e

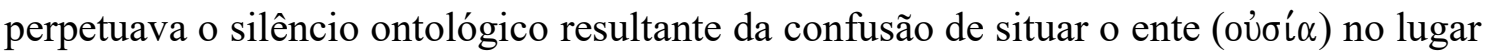
do Ser. Não obstante suas constantes tentativas em subtrair ao ego seu caráter substancial, o fenomenólogo ainda reiterava tais traços vetustos em detrimento do autêntico sentido do sum.

Havia, porém, algo mais a ser constatado sobre este preceito da exclusão de pressupostos, isto é, uma outra dificuldade que residia em sua própria operação. Pois, se já não bastasse o contrassenso de portar consigo uma forma "ontológica" tradicional, o preceito também provocava a definitiva condenação do pensamento fenomenológico ortodoxo ao enclausurar em seus parênteses o único ente capaz de responder a pergunta pelo Ser, o Dasein. Afinal, se o Ser sempre é Ser do ente, como pôr em curso uma investigação ontológica na ausência do ente que surge como sua condição de possibilidade? Ora, era justamente em razão desta privação que Heidegger se recusaria a empregar o método da eversio na constituição de sua ontologia fundamental. Assim, nada

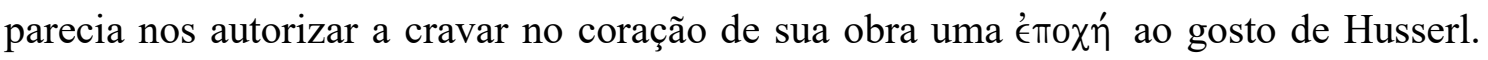
Nem mesmo a passagem da preleção Os problemas fundamentais da fenomenologia, na qual o termo "redução" era expressamente empregado. E por que? Porque ali o conceito aparecia envolto numa profunda ressignificação: não remetendo à nenhuma exclusão de pressupostos, a "redução" representava uma "re-condução" do campo de investigação do ente para o Ser. Mas não apenas isto: partindo da ideia de "re-condução", ela passava a indicar, em oposição ao seu caráter aparentemente negativo, a positividade de uma "construção" enquanto necessidade de que a ontologia tivesse seu princípio assegurado naquele ente que é o Dasein. Voltemo-nos então ao Dasein, diz Heidegger - e nele poderemos compreender sua determinação histórica e sua inserção numa tradição que insiste em velar o Ser (cujo nome não é outro senão metafísica); voltemo-nos, pois, e notemos por qual motivo a "construção redutiva" convoca-nos a uma destruição da história da filosofia. Uma destruição que, a bem dizer, não deixará transparecer nenhum traço do ditame cartesiano, sobretudo porque já não estará pautada por uma hostilidade em relação à história, mas sim por sua veneração: em vez de condensar a história numa sucessão de erros (tese marcante de uma filosofia que crê gerar-se sponte sua), o ato de destruir tomará o que há de positivo no passado e dele se servirá para livrar o Dasein hodierno das impropriedades oriundas das confusão entre Ser e ente. Vem daí, portanto, a possibilidade de entrada da fenomenologia na cena filosófica heideggeriana. Como 
quinhão de um passado silente, ela será submetida à crítica e poderá figurar como aquilo

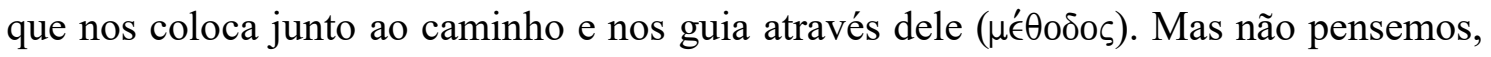
assegura Heidegger, que esta recuperação apenas repetirá as lições de Husserl. Não se trata disso. Pois, se é certo que a fenomenologia ressurge como método graças à destruição, ela o faz somente enquanto fenomenologia hermenêutica: à essência fenomenológica, revelada por sua etimologia (“deixar ver, sem entremeios, aquilo que se mostra"), seguiria a interpretação que o Dasein realiza de si mesmo em vista do desvelamento de seu Ser - ou em jargão heideggeriano, um despertar para o autoencontro.

Mas é claro que o afastamento da filosofia de Husserl não se detinha nesse ponto; ele ia além de uma reformulação da fenomenologia, acentuando-se no desdobramento das preleções marburguesas e em Ser e Tempo. Quando Heidegger se questionava por qual razão o Dasein seria merecedor do posto de lisonja numa ontologia fundamental em formação, não se podia deixar de observar em sua resposta o distanciamento do conceito de consciência transcendental. Afinal, o modo de Ser do Dasein já não correspondia ao modo de Ser do "ente simplesmente dado", mas caracterizava-se pela existência. E isto significava dizer que, ao contrário de partilhar da imanência da consciência fenomenológica, o ente da primazia é sempre transcendente, ou seja, é de maneira a ultrapassar a si mesmo, dirigindo-se "para fora", num mundo que se mostra como parte de sua constituição fundamental. É por isso que o Dasein jamais será - tal como quer a teoria do conhecimento - primordialmente no modo do "conhecer": estando junto-aomundo, seu modo de Ser originário não é outro senão o Ser-no-mundo. É por isso também que será preciso recusar o solipsismo proveniente da característica soberba das teorias do ego. Pois, se é verdade que o Dasein é no mundo, também é verdade o fato de que ai está com outros Daseins que se compreendem a partir do mundo mesmo: o Ser-no-mundo é inescapavelmente um Ser-com. Quer dizer então que o mundo e o outro fazem parte da constituição ontológica do Dasein? Sem dúvida. E será a partir desta constatação fundamental - afirma Heidegger - que tal ente poderá compreender não apenas a dominância exercida pelo impessoal e a mediocridade de sua condição decaída, mas também como a indiferença e o nivelamento ali vigentes abrem a via de acesso para a autêntica investigação do Ser do ente ${ }^{415}$. Diante disso, como ainda crer na necessidade de

415 “Primeiramente 'eu' não 'sou' no sentido da própria ipseidade (im Sinne des eigenen Selbst), mas os outros no modo do impessoal. É a partir deste e como este que eu sou 'dado' primeiramente para mim 'mesmo'. Primeiramente, o Dasein é o impessoal e assim permanece na maior parte das vezes. Quando o 


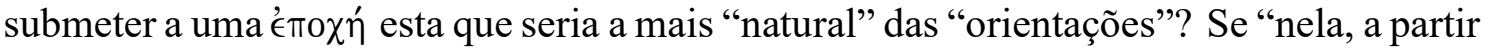
dela e contra ela" a autenticidade pode tomar seu lugar, sob qual justificativa exclúí-la do jogo filosófico? Ora, sem o "pressuposto" de que o Dasein "cresce" numa interpretação cotidiana (sendo de maneira imprópria porque indistinta daquela de todos os demais) não poderíamos vislumbrar suas estruturas existenciais; sem a cotidianeidade, não reconheceríamos a estrutura fundamental da disposição enquanto tonalidade afetiva responsável por abrir o Dasein ao mundo e fundamentar toda compreensão. Sim, repitamos: toda compreensão ${ }^{416}$, inclusive aquela impulsionada pela "exclusão de pressupostos" - supostamente depurada de todo traço afetivo, mas em cuja base jaz a singular afecção da "confiança na absoluta certeza do conhecimento sempre alcançável". E se rege, de fato, toda compreensão, a "compreensão do Ser" não lhe configurará uma exceção. Assim, estamos na contracorrente dos filósofos da eversio:

"Referi-me anteriormente, escreve Heidegger, por acasião da análise do conceito cartesiano de sujeito, ao fato de que Descartes disse que não teríamos propriamente nenhuma afecção do Ser enquanto tal. Há, no entanto, esta afecção do Ser enquanto tal (caso se queira utilizar este modo de expressão)"417.

Daí se vê quão magra é a leitura do intérprete que insiste em inserir na analítica existencial

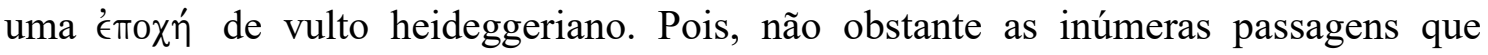
Heidegger dedica ao esclarecimento da questão, o exegeta ainda ignora que não se carece de nenhum colapso dos prejuízos, mas que basta o despertar da rara afecção da angústia para que se possa, enfim, estar em face do Ser: "a angústia não é nada senão a experiência pura e simples do Ser no sentido de Ser-no-mundo" "418. E quão mais equivocado não se tornará tal intérprete quando descobrir nos relatos de Heidegger que a angústia, ao estreitar o Dasein em si mesmo, já não desvelará o Ser cujo Apriori partilha da definição - oriunda da eversio - de "um sujeito fantasticamente idealizado" (ein phantastisch idealisiertes Subjekt $)^{419}$, mas é, na verdade, a cura que o método empenhava-se em afastar

\footnotetext{
Dasein descobre propriamente o mundo e o aproxima de si, quando abre a si mesmo seu próprio Ser, consuma-se este descobrimento de 'mundo' e a abertura do Dasein enquanto eliminação dos encobrimentos e obscurecimentos, enquanto um rompimento das distorções nas quais o Dasein se tranca contra si mesmo". Martin Heidegger, Sein und Zeit, §27, p. 129.

416 "Verstehen ist immer gestimmtes". Idem, Ibidem, §31, p. 142.

${ }^{417}$ Idem, Prolegomena zur Geschichte des Zeitbegriffs, GA 20, §30b, p. 403.

${ }^{418}$ Idem, Ibidem.

419 “'As ideias de um 'eu puro' e de uma 'consciência em geral' contém tão pouco o Apriori da subjetividade 'real' que elas passam por cima, ou seja, não vêem de forma alguma os caracteres ontológicos da facticidade e da constituição de Ser do Dasein". Idem, Sein und Zeit, §44c, p. 229.
} 
prematuramente nas páginas diluculares da "primeira meditação". O que então restará a este "cartesiano enrustido", fiel à impertinência de sua tarefa? Talvez reconhecer, antes de tudo, que falha como historiador da filosofia por tergiversar à história da filosofia; e que falha como (auto-intitulado) fenomenólogo por ignorar seus preceitos, assumindo pressupostos. Mas este reconhecimento seria, de fato, uma notícia tão temível? Quem sabe agora esse bom espírito não possa descobrir que mesmo nas fronteiras dos estudos heideggerianos - por mais estranha que soe a afirmação - seja possível não se portar como um provinciano. 


\section{Referências bibliográficas}
A) Bibliografia fundamental:
I - Obras de Edmund Husserl:

HUSSERL, Edmund. Prolegomena zur reinen Logik, Max Niemeyer Verlag, Tübingen, 1993. . Logische Untersuchungen, 2 volumes, Max Niemeyer Verlag, Tübingen, 1993. . Cartesianische Meditationen und Pariser Vorträge, Martinus Nijhoff, Haag, 1950.

. Philosophie als strenge Wissenchaft, Vittorio Klostermann, Frankfurt am Main, 1965.

. Die Krisis der europäischen Wissenchaften und die transzendentalen Phänomenologie, Martinus Nijhoff, Haag, 1976.

. Die Idee der Phänomenologie, Martinus Nijhoff, Haag, 1958.

. Ideen zu einer reinen Phänomenologie und phänomenologischen Philosophie - Erstes Buch, Felix Meiner Verlag, Hamburg, 2009.

. Ideen zu einer reinen Phänomenologie und phänomenologischen Philosophie - Drittes Buch, Martinus Nijhoff, Haag, 1952.

.Phänomenologische Psychologie, Martinus Nijhoff, Haag, 1968.

. Analysen zur passiven Synthesis, Martinus Nijhoff, Haag, 1966.

. Erste Philosophie: Erster Teil, Martinus Nijhoff, Haag, 1956. 
II - Obras de Martin Heidegger:

HEIDEGGER, Martin. Sein und Zeit, Max Niemeyr Verlag, Tübingen, 2006.

. Frühe Schriften, GA 1, Vittorio Klostermann, Frankfurt am Main, 1978.

. Zur Sache des Denkens, GA 14, Vittorio Klostermann, Frankfurt am Main, 2007.

. Prolegomena zur Geschichte des Zeitbegriffs, GA 20, Vittorio Klostermann, Frankfurt am Main, 1979.

- Einführung in die phänomenologische Forschung, GA 17, Vittorio Klostermann, Frankfurt am Main, 1994.

- Ontologie (Hermeneutik der Faktizität), GA 63, Vittorio Klostermann, Vittorio Klostermann, Frankfurt am Main, 1995.

. Die Grundprobleme der Phänomenologie, GA 24, Vittorio Klostermann, Frankfurt am Main, 1989.

. Wegmarken, GA 9, Vittorio Klostermann, Frankfurt am Main, 1976.

. Holzwege, GA 5, Vittorio Klostermann, Frankfurt am Main, 1977.

. Identität und Differenz, GA 11, Vittorio Klostermann, Frankfurt am Main, 2006.

. Phänomenologischen Interpretationen zu Aristoteles. Einführung in die phänomenologische Forschung, GA 61, Vittorio Klostermann, Frankfurt am Main, 1985.

. Aus der Erfahrung des Denkens, GA 13, Vittorio Klostermann, Frankfurt am Main, 1983. 
III - Obras de René Descartes:

DESCARTES, René. Meditationes de prima philosophia, edição bilíngüe, Editora Unicamp, Campinas, 2008.

. Regulae ad directionem ingenii et Cogitationes privatae, Felix Meiner Verlag, Hamburg, 2011.

. Principia Philosophiae, in: Oeuvres de Descartes (Charles Adam et Paul Tannery), Léopold Cerf, Paris, v. VIII, 1905.

. Discurso do método (introdução, análise e notas de Étienne Gilson), Martins Fontes, São Paulo, 2007.

B) Bibliografia complementar:

AGOSTINHO. Soliloqui, Bompiani (testo latino a fronte), Milano, 2002.

. Confessioni, Bompiani (testo latino a fronte), Milano, 2012.

ALVAREZ-VÁSQUEZ, Javier Y. Husserls 'Allgemeine Erkenntnistheorie' von 1902/03.

Zur Frühentwicklung der phänomenologischen Methode, UniversitätsBibliothek, Heidelberg, 2013, p. 1-21.

ARISTÓTELES. Le categorie, BUR (testo greco a fronte), Milano, 1997.

. De anima, Cambridge University Press, Cambridge, 1907.

BARBARAS, Renaud. Introduction à la philosophie de Husserl, Les éditions de la transparence, Paris, 2008.

BÉGOUT, Bruce. La réverbération logique, Revue Philosophique de Louvain, v.99, n.4, 2001, p. 564-592. 
BENOIST, Jocelyn. Egología y fenomenologia: la crítica heideggeriana de Husserl,

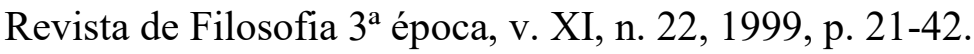

BERNET, Rudolf. Transzendentale Phänomenologie, Philosophy, Phenomenology, Sciences, Phaenomenologica 200, p. 41-70.

BROGAN, Walter A. Heidegger and Aristotle: the twofoldness of Being, State University of New York Press, New York, 2005.

BROUGH, John B. Consciousness is not a Bag: immanence, transcendence and constitution in 'The Idea of Phenomenology', Husserl Studies, n. 24, 2008, p. 177-191.

COURTINE, Jean-François. Les méditations cartésiennes de Martin Heidegger, Les études philosophiques, n.1, 2009, p. 103-115.

CAIRNS, Dorion. Conversations with Husserl and Fink, Martinus Nijhoff, The Hague, 1976.

DÁVILA, Nicolás Gómez. Escolios a un texto implícito, Atalanta, Girona, 2009.

DE WAELHENS, Alphonse. Descartes et la pensée phénoménologique, Revue néoscolastique de philosophie, n. 60, 1938, p. 571-589.

DEPRAZ, Natalie. Pratiquer la réduction : la prière du couer, Laval théologique et philosophique, v. 59, n. 3, 2003, p. 503-519.

. Edmund Husserl: adversus haereses mystikes?, Laval théologique et philosophique, v. 50, n. 2, 1994, p. 327-347.

DERRIDA, Jacques. La voix et Le phénomène, Presses Universitaires de France, Paris, 2009.

- Le problème de la gènese dans la philosophie de Husserl, Presses Universitaires de France, 2004. 
DIELS, Hermann \& KRANZ, Walther. Die Fragmente der Vorsokratiker, Weidmannsche Verlagsbuchhandlung, Berlin, 1960.

DRUMMOND, John J. The Transcendental and Psychological, Husserl Studies, n. 24, 2008, p. 193-204.

ECKHART, Meister. Predigten, Deustcher klassiker Verlag, Band 24, Frankfurt Am Main, 2008.

EUCLIDES. Elementa, B. G. Teubneri, 1883-1885 (reeditado por Richard Fitzpatrick, 2008).

FERRAZ, Marcus Sacrini Ayres. Lições do mundo-da-vida: o último Husserl e a crítica ao objetivismo, Scientiae Studia, v. 2, n. 3, São Paulo, 2004, p. 355-372.

. The making of phenomenology as an autonomous discipline, PhaenEx $8, \mathrm{n} .1$, $2013,208-232$.

FIGAL, Günther (et alii). Heideggers MarburgerZeit: Themen, Argumente, Konstellationen, Vittorio Klostermann, Frankfurt am Main, 2013.

FISETTE, Denis. Les cours de Marbourg et la phénoménologie, Philosophiques, v. 20, n. 2, p. 303-321, 1993.

. Introduction: les suites de la phénoménologie, Philosophiques, v. 20, n. 2, p. 247-265, 1993.

FONTANIER, Jean-Michel. Vocabulário latino da filosofia, Martins Fontes, São Paulo, 2009.

GADAMER, Hans-Georg. Los caminos de Heidegger, Herder, Barcelona, 2002.

GILSON, Étienne. La liberte chez Descartes et la théologie, Vrin, Paris, 1982. 
. Index scolatico-cartésien, Vrin, Paris, 1979.

. Étude sur le rôle de la pensée médiévale dans la formation du système cartésien, Vrin, Paris, 2005.

. O filósofo e a teologia, Paulus, Santo André, 2009.

HERRMANN, Friedrich-Wilhelm v. Hermeneutik und Reflexion, Vittorio Klostermann, Frankfurt am Main, 2000.

. Descartes 'Meditationen, Vittorio Klostermann, Frankfurt am Main, 2011.

.Husserl et Descartes, Revue de Métaphysique et Morale, 92e année, n.1, 1987, p. 4-24.

JARAN, François. Heidegger et la constitution onto-théologique de la métaphysique cartésienne, Heidegger Studies, 2003/19, p. 65-80.

JUNIOR, Bento Prado. Erro, ilusão, loucura, Editora 34, São Paulo, 2004. . Presença e campo transcendental. Consciência e negatividade na filosofia de Bergson, Edusp, São Paulo, 1898.

. Ipseitas, Autêntica, São Paulo, 2017.

KIERKEGAARD, Søren. É preciso duvidar de tudo, Martins Fontes, São Paulo, 2003. . O conceito de angústia, Editora Vozes, Petrópolis, 2010.

KISIEL, Theodore. The genesis of Heidegger's "Being and Time", University of California Press, Berkeley, 1995.

LEBRUN, Gérard. A filosofia e sua história, Cosac Naify, São Paulo, 2006. 
. Sobre Kant, Iluminuras, São Paulo, 2012.

LEHMANN, Karl. Vom Ursprung und Sinn der Seinsfrage im Denken Martin Heideggers, 2 volumes, tese de doutorado apresentada à Pontifícia Universidade Gregoriana, Roma, 1962.

LÉVINAS, Emmanuel. Descobrindo a existência com Husserl e Heidegger, Instituto Piaget, Lisboa.

LIBERA, Alain de. Sujet insigne et Ich-satz. Deux lectures heideggériennes de Descartes, Les études philosophiques, n.1, 2009, p. 85-101.

MAJOLINO, Claudio. La partition du réel: remarques sur l'eidos, la fantasia, l'effondrement du monde et l'être absolu de la conscience, Philosophy, Phenomenology and Sciences, Phaenomenologica 200, p. 573-660.

MANOUSSAKIS, John P. The phenomenon of God: from Husserl to Marion, American Catholic Philosophical Quarterly, n. 1, vol. 78, 2004, p. 53-68.

MARION, Jean-Luc. Reduction and givinness, Morthwestern University Press, Illinois, 1998.

. Sobre a ontologia cinzenta de Descartes, Instituto Piaget, Lisboa.

. Sur le prisme métaphysique de Descartes, PUF, Paris, 2004.

MEESSEN, Yves. Percée de l'ego: Maître Eckhart em phénomélogie, tese apresentada para a obtenção do título de doutor em filosofia na Universidade de Poitiers, 2006.

MOURA, Carlos Alberto Ribeiro de. Husserl: significação e fenômeno, Revista Dois Pontos, Curitiba/São Carlos, v. 3, n. 1 p. 37-61, abril 2006. 
. Crítica da razão na fenomenologia, Edusp, São Paulo, 1989.

NUNES, Benedito. Passagem para o poético. Filosofia e poesia em Heidegger, Edições Loyola, São Paulo, 2012.

. Heidegger, Edições Loyola, São Paulo, 2017.

. A Rosa o que é de Rosa: literatura e filosofia em Guimarães Rosa, Difel, Rio de Janeiro, 2013.

ONATE, Alberto Marcos. O lugar do transcendental, Rev. Filos., v. 19, n. 24, jan./jun. 2007, p. 131-145.

OVERGAARD, Søren. Husserl and Heidegger on Being in the world, Kluwer Academic Publishers, Dordrecht, 2004.

. Heidegger's early critique of Husserl, International journal of philosophical studies, vol. 11 (2), 157-175.

PERRIN, Christophe. Cogito me cogitare. Note pour server la généalogie et la téléologie d'une formule-clé de G. W. Leibniz à J.-L. Marion, Phainomena XXIII/88-89, p. 5-23.

- Sur l'anticartésianisme prétendu de Heidegger: le sens d'(une) Auseinandersetzung, $\Delta \alpha i ́ \mu \omega \nu$ - Revista Internacional de Filosofía, n.51, 2010, p. 137149.

. Entendre la Métaphysique. Les significations de la pensée de Descartes dans l'oeuvre de Heidegger, tese apresentada para a obtenção do título de doutor em filosofia na Universidade de Paris-Sorbonne, 2012.

RESE, Friederike (et alii). Heidegger und Husserl im Vergleich, Vittorio Klostermann, Frankfurt am Main, 2010. 
ROMANO, Claude. La Phénoménologie doit-elle demereur cartésienne?, Les études philosophiques, n. 100, 2012, p. 27-48.

SARTRE, Jean-Paul. Les carnets de la drôle de guerre, Gallimard, Paris, 1983.

SOKOLOWSKI, Robert. Introdução à fenomenologia, Edições Loyola, São Paulo, 2012.

STEIN, Ernildo. A questão do método na filosofia: um estudo do modelo heideggeriano, Duas Cidades, São Paulo, 1973.

. Compreensão e Finitude, Editora Unijuí, Ijuí, 2001.

. Pensar e Errar: um ajuste com Heidegger, Editora Unijuí, Ijuí, 2011.

THEODOROU, Panos. Husserl and Heidegger on reduction, primordiality and the categorial, Springer, Switerzland, 2015.

VALENTIM, Marco Antonio. Heidegger sobre a fenomenologia husserliana: a filosofia transcendental como ontologia, O que nos faz pensar?, n. 25, 2009, 213-238.

VOLPI, Franco. Heidegger e Aristotele, Editori Laterza, Roma/Bari, 2010.

Heidegger e Brentano: l'aristotelismo e il problema dell'univocità dell'essere nella formazione filosofica del giovane Martin Heidegger, Casa editrice dott. Antonio Milani, Padova, 1976.

Goodbye, Heidegger! in: Fenomenología y Hermeneutica, Editora Sylvia Tafra, Chile, 2008, p. 43-74.

- Rehabilitación de la filosofia práctica y neo-aristotelismo, Anuario Filosófico, 1999 (32), p. 315-342. 
. La maravilla de las maravillas: que el ente es. Wittgenstein, Heidegger y la superación 'etico-prática' de la metafísica, Topicos, n. 30, 2006, p. 197-231.

XOLOCOTZI, Angel. Dos décadas de una atormentada relación: Martin Heidegger e Edmund Husserl 1909-1929, Contribuiciones desde Coatepec, julio-diciembre, n.15, Universidad Autônoma del Estado de Méxic, Toluca, México.

. Der Umgang als Zugang: der hermeneutisch-phänomenologische 'Zugang' zum faktischen Leben in den frühen Freiburger Vorlesungen Martin Heideggers in Hinblick auf seine Absetzung von der transzendentalen Phänomenologie Edmund Husserl, Duncker \& Humboldt, Berlin, 2002.

ZAHAVI, Dan. Husserls Phänomenologie, Mohr Siebeck, Tübingen, 2009. 